GUSTAVO AGUIAR

Túneis escavados em solo por máquina tuneladora: conceituação, comportamento do maciço e modelagem numérica

São Paulo 


\section{GUSTAVO AGUIAR}

Túneis escavados em solo por máquina tuneladora: conceituação, comportamento do maciço e modelagem numérica

Dissertação apresentada à Escola Politécnica da Universidade de São Paulo para a obtenção do título de Mestre em Ciências

Área de Concentração: Engenharia Geotécnica

Orientador: Prof. Dr. José Jorge Nader

\section{São Paulo}


Este exemplar foi revisado e alterado em relação à versão original, sob responsabilidade única do autor e com a anuência de seu orientador.

São Paulo, 12 de abril de 2017

Assinatura do autor:

Assinatura do orientador:

\section{Catalogação-na-publicação}

Aguiar, Gustavo

Túneis escavados em solo por máquina tuneladora: conceituação, comportamento do maciço e modelagem numérica / G. Aguiar -- versão corr. -São Paulo, 2017.

$148 \mathrm{p}$.

Dissertação (Mestrado) - Escola Politécnica da Universidade de São Paulo. Departamento de Engenharia de Estruturas e Geotécnica.

1.Túnel 2.Máquina Tuneladora 3.Análise numérica I.Universidade de São Paulo. Escola Politécnica. Departamento de Engenharia de Estruturas e Geotécnica II.t. 


\section{AGRADECIMENTOS}

Ao professor José Jorge Nader pela contribuição, apoio e confiança e por embarcar no tema de túneis comigo. Ao professor Tarcísio Celestino pelas valiosas contribuições no início deste trabalho, que ajudaram a definir o caminho a ser seguido.

Aos amigos e companheiros de graduação, pela descontração proporcionada durante os anos na Poli. Aos colegas da pós-graduação, pelas conversas e ajudas. Aos professores da Poli, em especial aos do departamento de Geotecnia, pelos sólidos ensinamentos e contribuições para minha formação.

À Ana Cristina e demais colegas da Bureau de Projetos, por me direcionarem no caminho dos túneis e pela contribuição para minha formação profissional. Ao mestre Harada, pelas preciosas dicas e ensinamentos, sempre transmitindo sua grande e pioneira experiência com máquinas tuneladoras. Ao Ivo José, pelas incansáveis discussões técnicas e parceria nos desafios profissionais. Ao Marco Aurélio, pelos ensinamentos, confiança e cujo apoio foi fundamental para que este trabalho fosse possível.

À minha família, pelo amor e incentivo dado em todas as situações.

À Isa, pelo companheirismo e apoio incondicional. 


\section{RESUMO}

Este trabalho apresenta um estudo a respeito do comportamento do solo durante a escavação de um túnel, com foco na metodologia de escavação mecanizada. São abordadas diretrizes para a modelagem numérica de túneis com o emprego de diferentes métodos de cálculo, distintos modelos constitutivos para representação do comportamento do solo e duas maneiras de se representar o revestimento da escavação. Alguns conceitos fundamentais relacionados a escavações de túneis de grande diâmetro em solo com o emprego de máquinas tuneladoras são descritos, como os tipos de máquinas existentes (com ênfase nas máquinas do tipo EPB Earth Pressure Balance), princípios de funcionamento e modos de operação, além de uma comparação deste método com a metodologia sequêncial tradicional. É realizada uma revisão bibliográfica sobre distintos métodos de cálculo para estimar a estabilidade de uma escavação, a previsão da deformação no maciço e os esforços atuantes no revestimento do túnel. $O$ trabalho também apresenta uma revisão de publicações recentes a respeito da modelagem numérica de túneis escavados mecanicamente, destacando algumas diferenças em relação à metodologia sequencial. Uma das diferenças é com relação à simulação do revestimento do túnel, com a possibilidade de se considerar as propriedades das juntas dos anéis. Outro ponto distinto é o método de cálculo empregado, levando em conta na simulação aspectos específicos da escavação mecanizada, como pressão de frente aplicada, vazio anelar e injeção de grout. É feita uma breve introdução e são apresentados os conceitos básicos de dois modelos constitutivos do solo: o modelo elastoplástico perfeito conhecido como Mohr-Coulomb e o modelo elastoplástico com endurecimento Hardening Soil. Utilizando alguns dos conceitos estudados na revisão bibliográfica, são realizadas análises numéricas bidimensionais retroanalisando um caso real de escavação com tuneladora. Foi utilizado o programa de elementos finitos Plaxis para realizar comparações entre os métodos de cálculo do alívio de tensões e da contração, além da simulação do revestimento com ou sem a consideração das juntas. Por fim é feita uma análise crítica dos resultados obtidos nas diferentes modelagens numéricas.

Palavras-chave: Túnel. Máquina tuneladora. Análise numérica. 


\begin{abstract}
This research presents a study about the soil behavior during the excavation of a tunnel, focusing on the mechanized excavation methodology. Guidelines for the numerical modeling of tunnels with the use of different calculation methods, distinct constitutive models to characterize the soil behavior and two ways of representing the lining of the excavation are addressed. Relevant aspects regarding excavations of large diameter tunnels in soil with the use of TBM (Tunnel Boring Machine) are presented, like types of machines, with the focus on the Earth Pressure Balance (EPB) machines, fundamental concepts of the methodology and operation modes, besides a comparison of this method with the traditional sequential methodology. A literature review on different methods of calculation to estimate the excavation stability, the prediction of ground deformation and the efforts acting in the tunnel lining is made. The research also presents a review of recent publications regarding numerical modeling of mechanically excavated tunnels, highlighting some differences with the sequential method. One of these differences is related to the simulation of the tunnel lining, with the possibility of considering the properties of the ring joints. Another different point is the calculation method employed, considering in the simulation specific aspects of mechanized excavation, as front pressure applied, ring void and grout injection. A brief introduction is made about constitutive models to represent the soil behavior and the basic concepts of two constitutive soil models are presented: Mohr-Coulomb and Hardening Soil. Using some of the concepts studied in the literature review, it is performed two-dimensional numerical analysis with a back-analysis of a real case, using the finite element model program Plaxis, comparing the calculation methods of stress relieving and contraction, as well as the tunnel lining simulation with or without consideration of the joints. Finally, it is made a critical analysis of the results of the numerical simulations.
\end{abstract}

Keywords: Tunnel. Tunnel boring machine. Numerical analysis. 


\section{SUMÁRIO}

1 INTRODUÇÃO

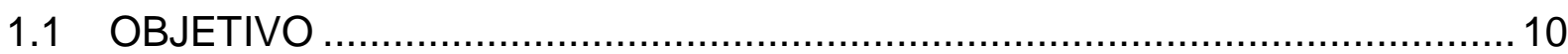

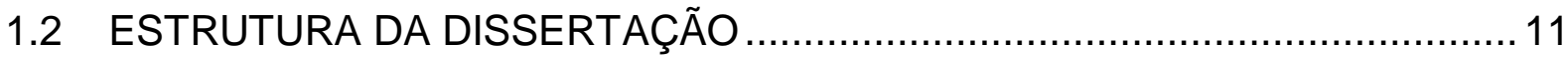

2 ESCAVAÇÃO MECANIZADA DE TÚNEIS DE GRANDE DIÂMETRO................13

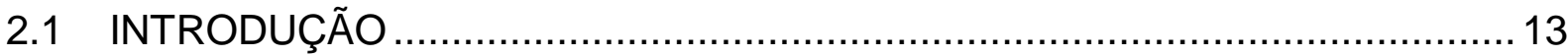

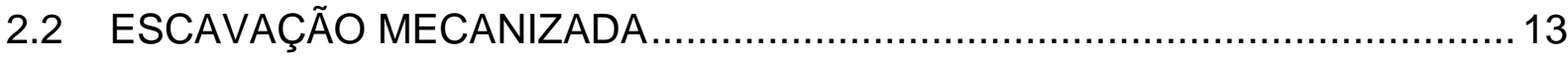

2.2.1 Principais tipos de máquinas TBM ...................................................... 14

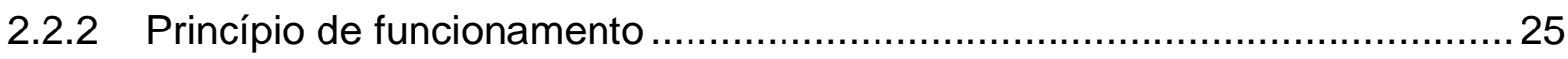

2.2.3 Estabilização da frente e controle das deformações ..................................29

2.2.4 Modos de operação e controles dos parâmetros operacionais de uma

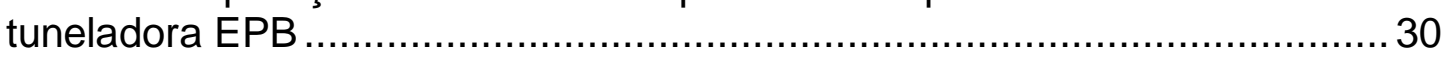

2.3 COMPARAÇÃO ENTRE ESCAVAÇÃO MECANIZADA E ESCAVAÇÃO TRADICIONAL (MÉTODO SEQUENCIAL) ………...................................... 32

3 COMPORTAMENTO DO MACIÇO DURANTE A ESCAVAÇÃO DE UM

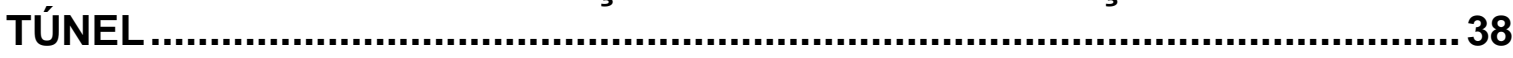

3.1 ANÁLISES DE ESTABILIDADE DA FRENTE …......................................... 40

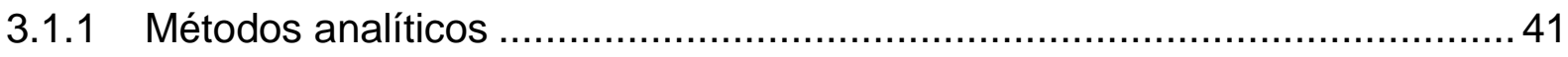

3.2 ESTIMATIVA DAS DEFORMAÇÕES INDUZIDAS NO MACIÇO ...................53

3.2.1 Métodos empíricos para previsão de recalques superficiais ........................56

3.3 AVALIAÇÃO DOS ESFORÇOS NO SUPORTE DA ESCAVAÇÃO ..................60

3.3.1 Métodos analíticos para estimativa de esforços nos suportes .......................62

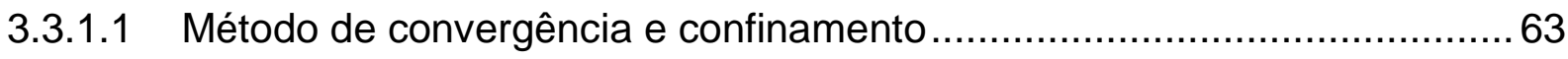

3.3.1.2 Método das reações hiperestáticas ...................................................... 70

4 SIMULAÇÕES NUMÉRICAS APLICADAS A TÚNEIS....................................75

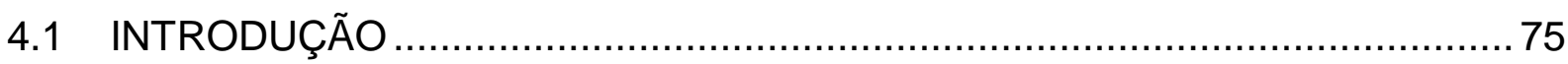

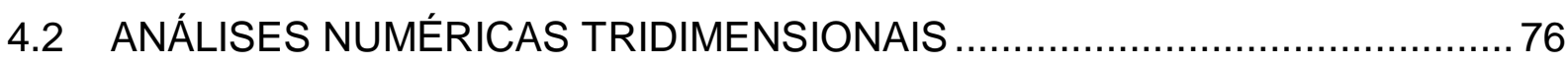

4.3 ANÁLISES NUMÉRICAS BIDIMENSIONAIS - MÉTODOS DE CÁLCULO ......81

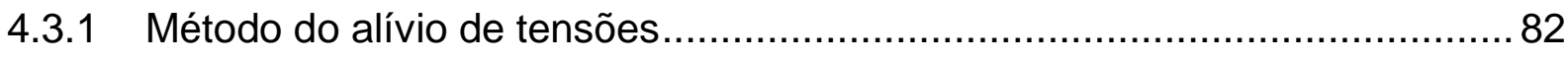

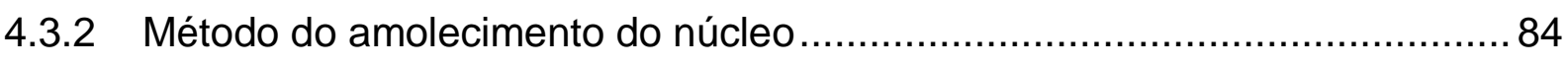

4.3.3 Método do módulo de elasticidade hipotético do revestimento ...................... 85

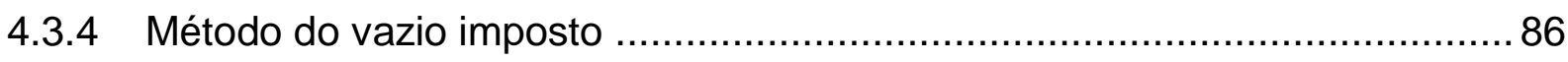

4.3.5 Método da contração (ou método do controle da perda de volume) ….......... 87

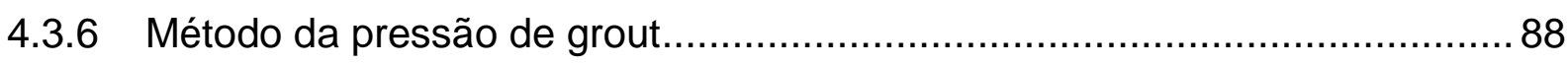


4.4 ANÁLISES NUMÉRICAS - MODELAGEM DO REVESTIMENTO ….............. 89

4.5 ANÁLISES NUMÉRICAS - CAPACIDADES E LIMITAÇÕES .........................95

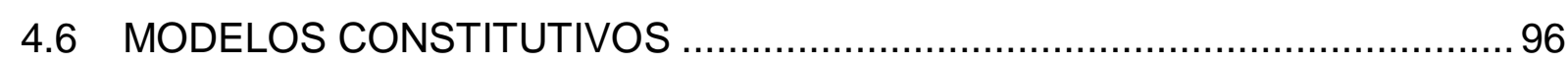

4.6.1 Modelos elastoplásticos: conceitos básicos …………….......................97

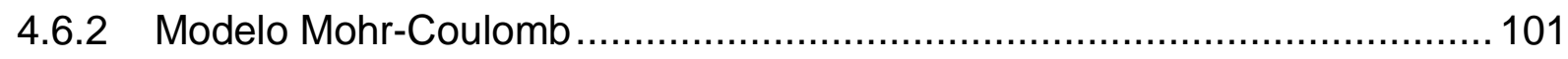

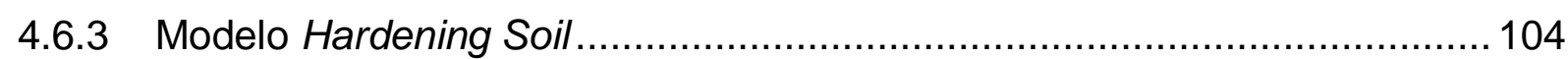

5 SIMULAÇÕES NUMÉRICAS E ESTUDO DE CASO ........................................ 109

5.1 DESCRIÇÃO DAS SEÇÕES ANALISADAS .......................................... 110

5.2 DEFINIÇÃO DOS PARÂMETROS GEOLÓGICO-GEOTÉCNICOS …...........113

5.3 ESTUDO DA REPRESENTAÇÃO DO COMPORTAMENTO DO SOLO PELOS MODELOS CONSTITUTIVOS .................................................... 122

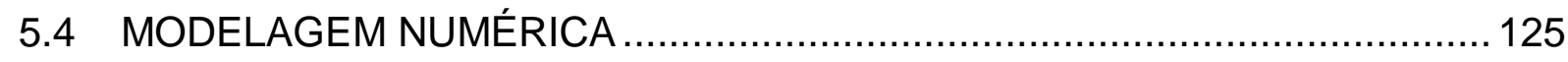

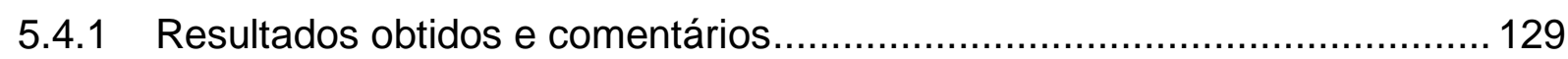

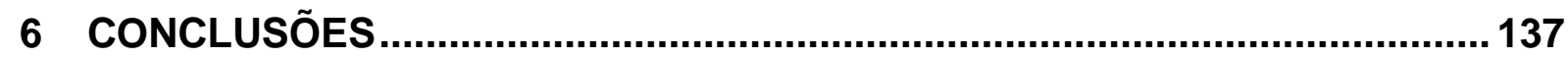

6.1 SUGESTÕES PARA TRABALHOS FUTUROS ........................................... 140

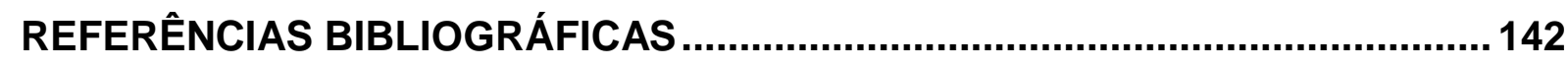




\section{INTRODUÇÃO}

Nas últimas décadas tem sido observado um expressivo aumento na necessidade de aproveitamento dos espaços subterrâneos, principalmente em metrópoles densamente ocupadas. A urbanização e expansão das cidades requerem a execução subterrânea das principais obras de infra-estrutura urbana, tais como obras para transporte de pessoas e materiais, instalação de redes de utilidades públicas, estocagem, entre outras, para assim minimizar a ocupação do espaço na superfície e reduzir o impacto físico, visual e ambiental durante a construção e operação dos sistemas instalados.

Durante a execução de túneis em regiões urbanas, a previsão do comportamento do maciço escavado é de fundamental importância, já que durante a escavação são induzidas movimentações no terreno que podem resultar em danos em estruturas próximas, redes públicas e até mesmo no colapso dos túneis. Desta maneira, uma correta modelagem do problema é fundamental para antever e mitigar possíveis ocorrências.

Inicialmente, os projetos para obras de escavação subterrânea eram baseados em métodos de dimensionamento empíricos e com base em experiências anteriores em obras semelhantes. Posteriormente, com o desenvolvimento da engenharia geotécnica, passaram a ser utilizados métodos semi-empíricos e métodos analíticos simplificados baseados nos fundamentos da teoria da elasticidade. Paralelamente, foram sendo desenvolvidos também modelos constitutivos mais elaborados para representação do comportamento do solo, incluindo conceitos da teoria da plasticidade. Atualmente, com a disponibilidade crescente dos recursos computacionais, é possível realizar análises numéricas de problemas complexos, resultando em projetos mais detalhados e com melhor acurácia na previsão do comportamento do solo.

As metodologias executivas de túneis de grandes diâmetros também vêm apresentando substanciais evoluções nas últimas décadas, principalmente com o desenvolvimento de máquinas tuneladoras, que têm sido utilizadas com bastante sucesso em túneis urbanos. Umas das principais vantagens da execução de túneis com máquinas tuneladoras, em especial as máquinas do tipo de pressão de terra balanceada, ou Earth Pressure Balance (EPB), é a possibilidade do equilíbrio das 
tensões no maciço na frente de escavação, reduzindo assim substancialmente os recalques superficiais. Não obstante, a metodologia convencional para escavação de túneis, utilizando o New Austrian Tunneling Method (NATM), ainda é bastante empregada.

\subsection{OBJETIVO}

O foco principal desta pesquisa é o estudo do comportamento do solo durante escavações realizadas pela metodologia mecanizada. Serão apresentados alguns conceitos teóricos a respeito do comportamento do maciço durante a execução de um túnel e sobre modelagem numérica de uma escavação. Será reproduzido em um programa de elementos finitos um caso real de uma escavação mecanizada utilizando um modelo bidimensional e empregando dois métodos de cálculo: o método do alívio das tensões e o método da contração. Serão analisados e comparados os resultados de deformações no maciço e esforços no revestimento obtidos pelos dois métodos. Será estudada também a capacidade de dois modelos constitutivos distintos de representar as deformações que ocorrem no maciço sob diferentes solicitações e sua aplicabilidade para representar a escavação de um túnel. A representação do revestimento do túnel, levando em conta a simulação das juntas entre segmentos, é também objeto de análise.

Em complemento, serão apresentados alguns conceitos fundamentais e princípios de funcionamento de máquinas tuneladoras para escavação de túneis de grande diâmetro em solo, com o intuito de ampliar o conhecimento nacional sobre este assunto. Serão fornecidos mais detalhes sobre máquinas do tipo de pressão de terra balanceada (conhecidas como EPB - Earth Pressure Balance), que é o tipo de máquina que vem sendo mais utilizado no Brasil. Mesmo com a crescente utilização deste método para execução de túneis, a elaboração de estudos e pesquisas nacionais sobre este assunto não tem acompanhado os desenvolvimentos tecnológicos ocorridos nos últimos anos. O conhecimento nacional a respeito da metodologia convencional já está bem consolidado e autores brasileiros são reconhecidos internacionalmente nesta área. O mesmo não se observa com relação à metodologia mecanizada, não havendo até a elaboração deste trabalho nenhuma pesquisa nacional a respeito deste tema. 


\subsection{ESTRUTURA DA DISSERTAÇÃO}

Esta dissertação está estruturada em 6 capítulos.

No capítulo 2 são apresentados alguns conceitos básicos a respeito de escavações mecanizadas, abordando-se tipos de máquinas existentes, princípios de funcionamento, modos de operação, condicionamento do maciço e informações relevantes a serem consideradas para realização de estudos, pesquisas, projetos e simulações a respeito desta metodologia. Apresenta-se também uma comparação deste método com a metodologia convencional, que já está consagrada e bem desenvolvida no Brasil.

O capítulo 3 consiste em uma revisão bibliográfica do comportamento do solo durante a escavação de um túnel, com ênfase em métodos de cálculo para verificação da estabilidade da escavação, estimativa de deformações no maciço e determinação de esforços atuantes no revestimento do túnel. São indicados métodos de cálculo empíricos e analíticos sobre estes temas.

O capítulo 4 contempla estudos sobre simulações numéricas aplicadas a túneis, abordando-se análises bi e tridimensionais e distintos métodos de cálculo para representação da escavação e para modelagem do revestimento. São mostrados também alguns conceitos fundamentais sobre dois modelos constitutivos para representação do solo - o modelo elastoplástico perfeito, conhecido como MohrCoulomb, e o modelo elastoplástico com endurecimento Hardening Soil.

No capítulo 5 são apresentadas análises numéricas bidimensionais em elementos finitos no programa Plaxis 2D simulando uma escavação mecanizada, contemplando alguns dos conceitos discutidos nos capítulos anteriores. É realizada uma interpretação dos resultados estimados para os recalques superficiais e esforços no revestimento. É avaliada a influência do método de cálculo e da maneira de se representar o revestimento nos resultados obtidos pelos modelos. Por fim, no capítulo 6 são apresentadas as conclusões gerais deste trabalho e sugestões para futuras pesquisas relacionadas a escavações mecanizadas. 
2 ESCAVAÇÃO MECANIZADA DE TÚNEIS DE GRANDE DIÂMETRO 


\section{ESCAVAÇÃO MECANIZADA DE TÚNEIS DE GRANDE DIÂMETRO}

\subsection{INTRODUÇÃO}

O objeto de estudo deste trabalho são túneis de grande diâmetro escavados em solo ou rocha branda. Dentre as metodologias executivas atualmente utilizadas para escavação de túneis de grande diâmetro, podem-se destacar dois grupos: escavação de forma mecanizada utilizando máquina tuneladora (TBM - Tunnel Boring Machine), que permite o controle da pressão aplicada ao terreno durante a escavação e dispõe de um escudo metálico no perímetro da escavação; e métodos de construção sequencial, também descritos como convencionais ou NATM (New Austrian Tunneling Method), em que a escavação e instalação do suporte no maciço são realizadas de maneira sequencial, podendo a escavação ser parcializada em diversas etapas e estando a frente de escavação submetida à pressão atmosférica.

A seguir serão apresentadas as principais características e descritos detalhes da metodologia de escavação mecanizada em solo, incluindo tipos de máquinas existentes, princípios de funcionamento e considerações a respeito do controle das deformações e estabilidade da frente. Por fim, é feita uma comparação entre ambas as metodologias (mecanizada e convencional), apontando vantagens e desvantagens de cada uma.

\subsection{ESCAVAÇÃO MECANIZADA}

Túneis mecanizados são todos aqueles túneis cuja escavação é realizada mecanicamente, por meio do uso de tuneladoras com dentes, picaretas ou discos cortantes (ITA, 2000). Define-se aqui túneis de grande diâmetro como aqueles com dimensões mínimas para comportar estruturas metroferroviárias e rodoviárias. São usualmente túneis com diâmetro mínimo de $6,0 \mathrm{~m}$, ou seja, com área de escavação a partir de $30 \mathrm{~m}^{2}$. Denomina-se mega tuneladora uma máquina com diâmetro superior a $14,0 \mathrm{~m}$. Até o final de 2016, a maior máquina tuneladora para escavação em solo em operação possuía diâmetro de $17,5 \mathrm{~m}$, para escavação de um túnel com seção de $240 \mathrm{~m}^{2}$.

A utilização de máquinas tuneladoras de grande diâmetro vem crescendo nos últimos anos no Brasil. A expansão dos projetos metroviários em diversas cidades 
aliada à maior confiabilidade da tecnologia e à viabilidade econômica em algumas condições vem propiciando um aumento da utilização deste tipo de máquina e, por consequência, uma necessidade de ampliação em âmbito nacional de estudos, pesquisas e desenvolvimentos de tecnologias para esta metodologia. Para exemplificar o crescimento de utilização desta metodologia, são ilustrados na Figura 2.1 os métodos construtivos adotados nos túneis do Metrô de São Paulo em diversas linhas por ordem cronológica, inclusive contabilizando os trechos que estavam em implementação, segundo Rocha et al. (2014).

Figura 2.1 - Métodos construtivos utilizados nas linhas do Metrô de São Paulo.

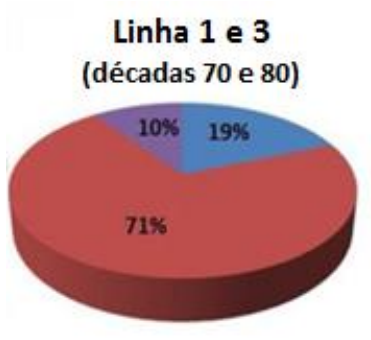

Linha 5 Capão Redondo - Chác. Klabin (décadas 2000 e 10)

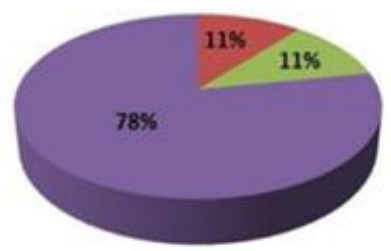

Linha 2

(décadas 90 e 2000)

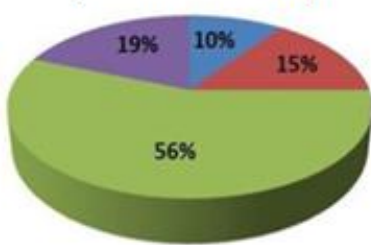

Linha 6

Brasilândia - São Joaquim (décadas 10 e 20 - previsão)

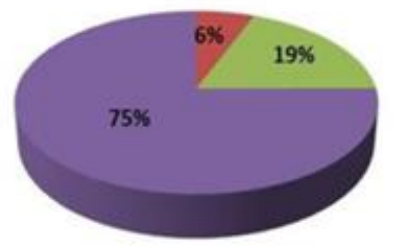

Fonte: adaptado de Rocha et al. (2014).

\subsubsection{Principais tipos de máquinas TBM}

Nas últimas décadas houve um intenso aperfeiçoamento e desenvolvimento de diferentes tipos de máquinas tuneladoras para possibilitar a escavação de túneis em distintas condições geotécnicas e se adequar às necessidades dos projetos. A seguir são apresentados brevemente os principais tipos de máquinas utilizadas atualmente para escavações em solos ou rochas brandas, de acordo com a classificação proposta pela International Tunnelling and Underground Space Association (ITA, 2000). A descrição a seguir não contempla os diversos tipos existentes de máquinas para escavação em rocha, pois este não é o foco deste trabalho. 
Pode-se dividir as máquinas utilizadas para escavação em solos ou rochas brandas em dois grupos: máquinas com suporte temporário somente periférico (escudo) e com a frente de escavação aberta e máquinas com suporte temporário periférico e frontal (cabeça de corte). Máquinas de frente aberta são utilizadas em maciços competentes em que a frente de escavação não necessita de suporte. As escavações podem ocorrer tanto acima como abaixo do lençol freático, como descrito a seguir:

- Couraças de frente aberta (Open Face Shield TBMs) - máquinas sem sistema de regulação de pressão na frente de escavação. O perímetro da escavação é protegido por um escudo cilíndrico (couraça) de aço até que o revestimento seja instalado. Enquanto ocorre a escavação, o escudo é empurrado para frente e suporta a pressão do terreno circundante (Figura 2.2). A parte superior do escudo pode ter uma projeção para frente da máquina visando proporcionar melhores condições de estabilização do terreno, além de evitar sobreescavações e recalques excessivos. Este tipo de máquina é utilizado quando as escavações ocorrem acima do lençol freático ou se o fluxo de água para dentro do túnel não é significativo. Tuneladoras deste tipo foram empregadas na execução de um trecho da Linha 1 do Metrô de São Paulo na década de 70.

Figura 2.2 - Couraça de frente aberta.

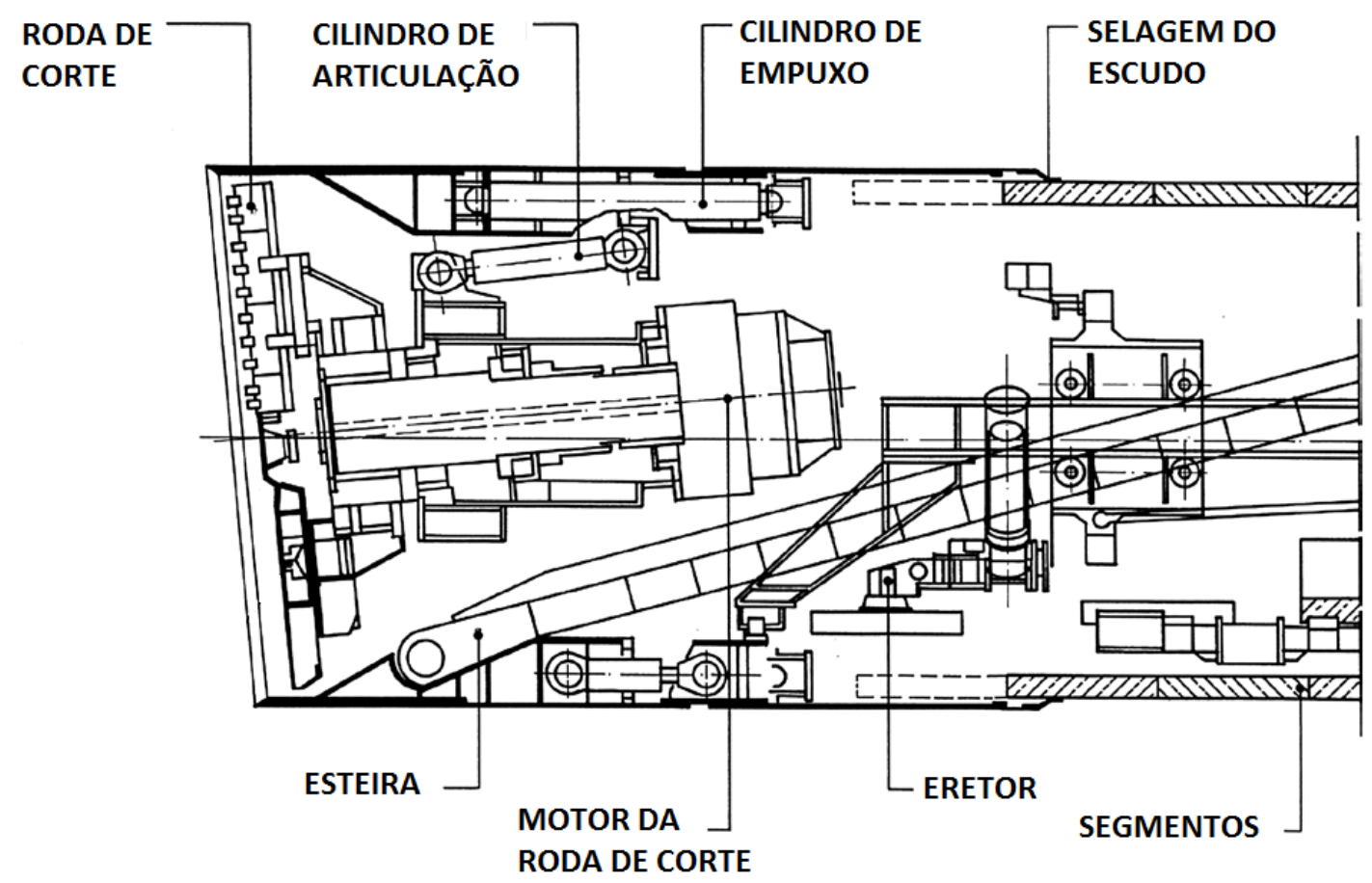

Fonte: adaptado de Maidl et al. (2012). 
- Couraças de frente aberta com ar comprimido - tuneladoras fechadas com escudo cilíndrico e com a utilização de ar comprimido para neutralizar a pressão hidrostática do solo (Figura 2.3). São máquinas especialmente adequadas para a escavação em solos competentes que não precisam de estabilização da frente, porém em escavações abaixo do lençol freático. Devido aos riscos e dificuldades de se trabalhar sob ar comprimido, este tipo de equipamento não vem sendo utilizado recentemente em túneis de grande diâmetro. Uma tuneladora deste tipo foi utilizada na construção da Linha 2 do Metrô de São Paulo.

Figura 2.3 - Couraça de frente aberta com ar comprimido.

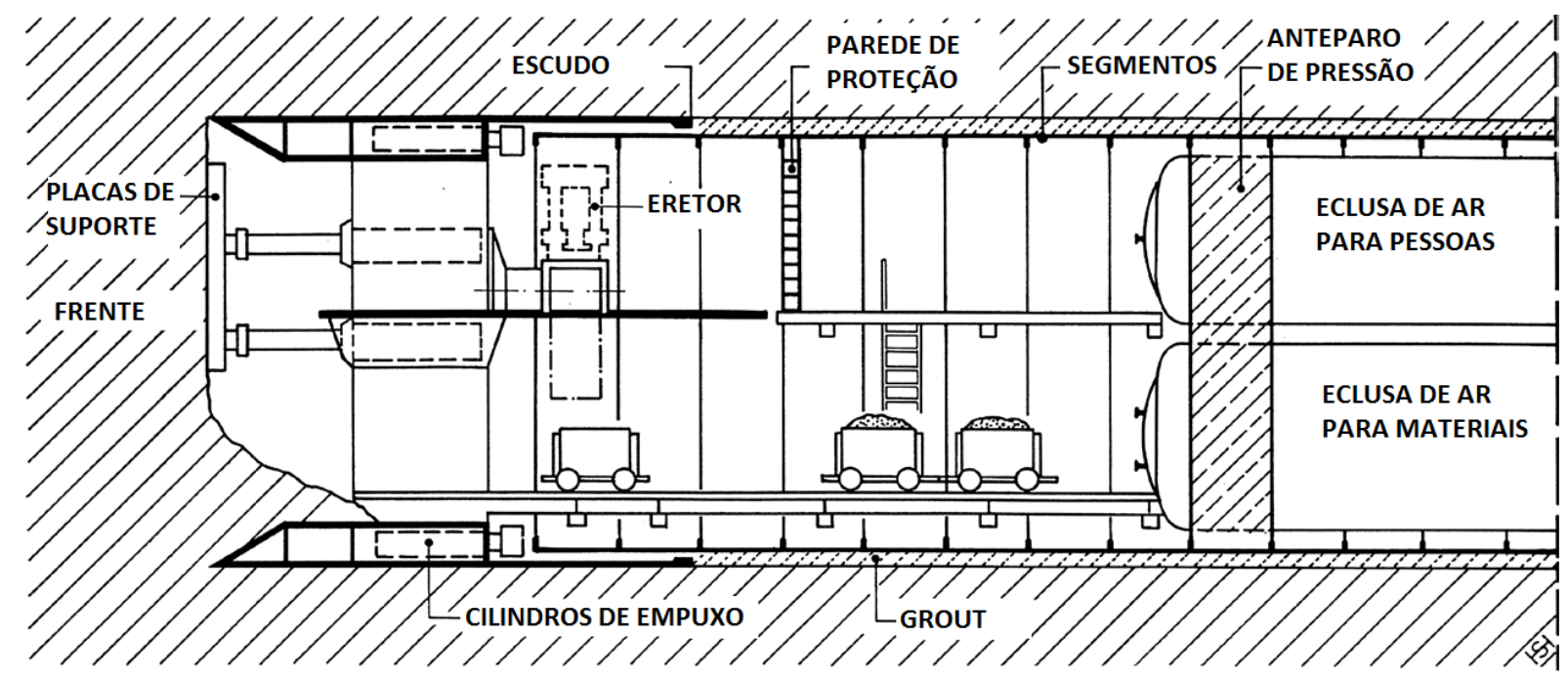

Fonte: adaptado de Maidl et al. (2012).

Quando existe o risco de o maciço a ser escavado apresentar instabilidade de frente ou quando se verificam altas cargas hidrostáticas na frente de escavação, recorre-se a máquinas de frente fechada que permitem equilibrar a tensão na frente da escavação. Os dois principais tipos são descritos a seguir:

- Tuneladora com pressão de terra balanceada - conhecida como tuneladora EPBTBM (Earth Pressure Balance). Consistem em tuneladoras fechadas com escudo e com uma cabeça de corte com aberturas, que operam sob pressão de frente balanceada, utilizando o próprio material escavado juntamente com espumas e/ou polímeros para estabilizar a frente de escavação. Esta é separada do restante da máquina por uma câmara pressurizada, onde a pressão de frente é aplicada. A manutenção desta pressão é feita por meio do controle da retirada do material escavado da câmara de escavação por um parafuso sem-fim. Contribui também para o controle da pressão de frente a força exercida pelos cilindros de avanço, que 
são responsáveis por empurrar a máquina para frente se apoiando nos segmentos de revestimento previamente instalados. Este tipo de tuneladora também pode operar em modo aberto (Figura 2.4) ou com ar comprimido, caso as condições do maciço permitam. Adiante serão descritas em mais detalhes as principais partes de uma máquina EPB. Máquinas deste tipo foram utilizadas nas obras das Linhas 4 e 5 do Metrô de São Paulo e da Linha 4 do Metrô do Rio de Janeiro.

Figura 2.4 - Tuneladora de pressão de terra balanceada (EPB-TBM).

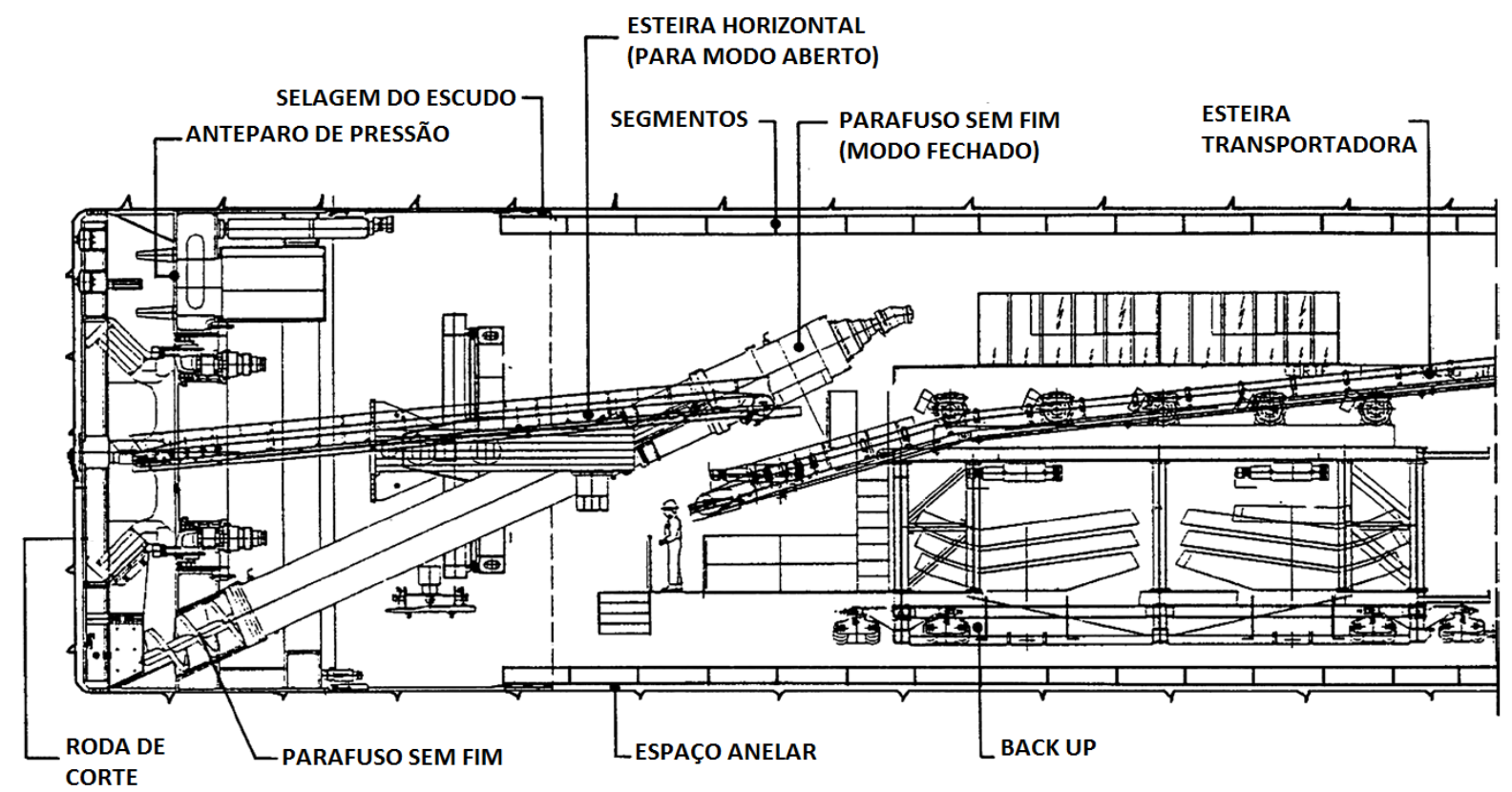

Fonte: adaptado de Maidl et al. (2012).

- Tuneladora de lama - também conhecida como Slurry TBM. São tuneladoras fechadas com escudo e que propiciam a estabilização da frente de escavação por meio de um fluído pressurizado, geralmente bentonita. Também possui uma câmara pressurizada para separar a frente de escavação do restante da máquina. A mistura de água com bentonita (chamada de slurry), cuja concentração é definida de acordo com as propriedades do solo a ser escavado, é bombeada para a câmara de escavação e penetra no maciço formando uma membrana impermeável (conhecida como filter cake), que garante a estabilidade da frente de escavação. O material escavado é bombeado para fora da câmara e posteriormente deve ser separado da bentonita para que esta possa ser utilizada novamente no processo de escavação (Figura 2.5). São tuneladoras utilizadas, principalmente, em solos sem coesão, com material instável e submetido à alta pressão hidrostática. No Brasil, até 2015, ainda não haviam sido utilizadas máquinas de grande diâmetro deste tipo. 
Figura 2.5 - Tuneladora de lama (Slurry TBM) e planta de separação de bentonita.

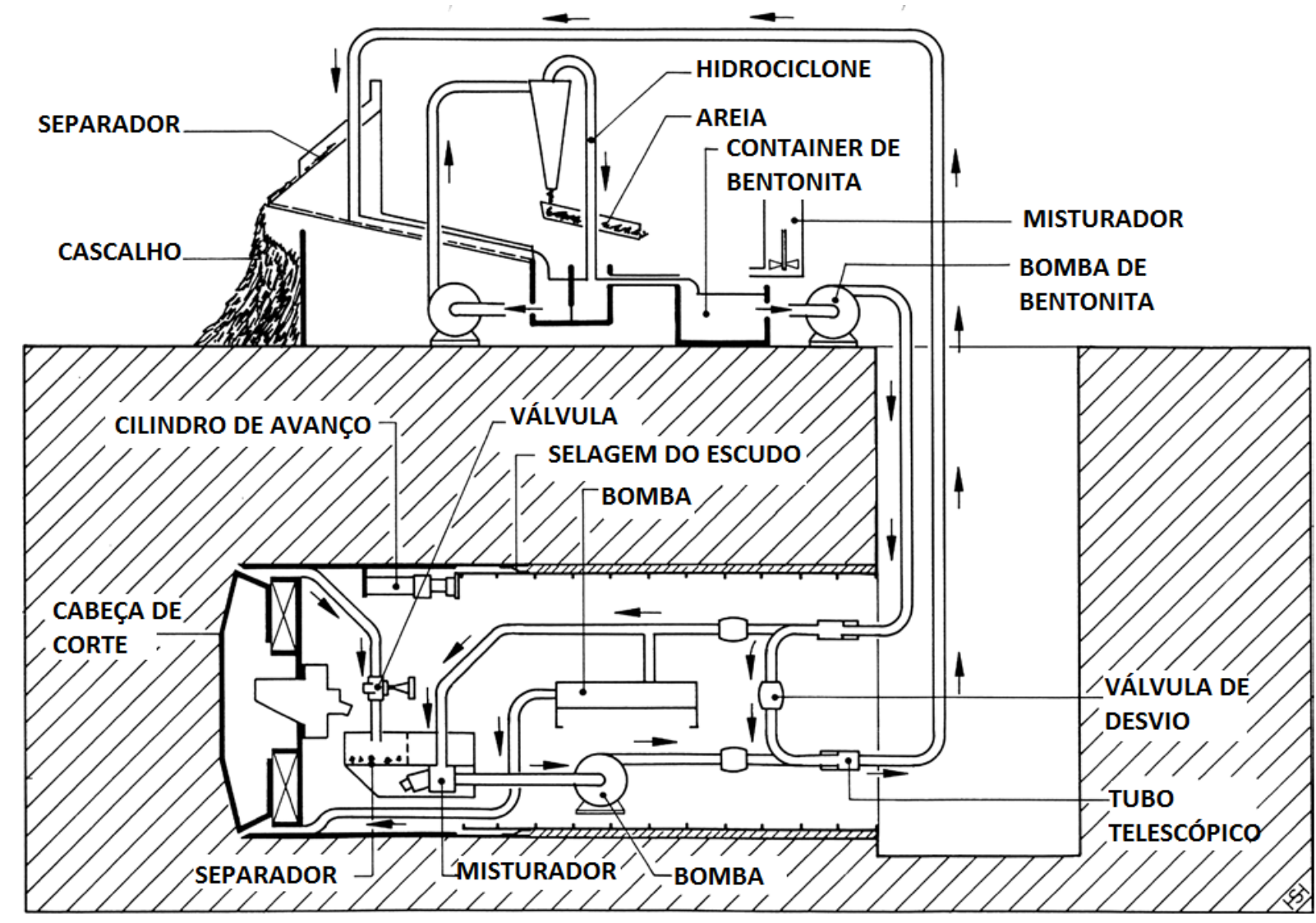

Fonte: adaptado de Maidl et al. (2012).

A escolha entre a utilização de uma máquina do tipo EPB ou de lama depende de diversos fatores, dentre os quais destacam-se o tipo de solo a ser escavado e a área de canteiro disponível - no caso de máquinas de lama é necessária grande área na superfície disponível para instalação da planta de separação de bentonita. Além disso, restrições ambientais podem ser um impeditivo para utilização e descarte de bentonita.

A faixa de aplicabilidade em função do tipo de solo para máquinas EPB e de lama foi objeto de estudo de diversos autores. Maidl (1995, apud Maidl et al., 2012) apresenta uma faixa no gráfico da curva granulométrica dividindo zonas onde a escavação em EPB é aplicável (Figura 2.6). O autor ressalta que este tipo de máquina é em geral adequada para solos com conteúdo de finos (siltes e argilas) acima de $30 \%$, onde a principal preocupação se refere à obstrução por adesão (denominada clogging) da argila na roda de corte. Nesta condição, o solo escavado é condicionado com adição de água ou tensoativos de maneira a elevar a umidade da argila para se atingir o limite de liquidez e garantir fluidez da mistura para que não 
haja entupimento por adesão da argila na roda de corte. Em solos granulares, por outro lado, é necessária utilização de aditivos como espumas e polímeros para viabilizar a escavação em EPB, para que a mistura tenha fluidez e permeabilidade adequadas.

Figura 2.6 - Aplicabilidade de escavação em EPB.

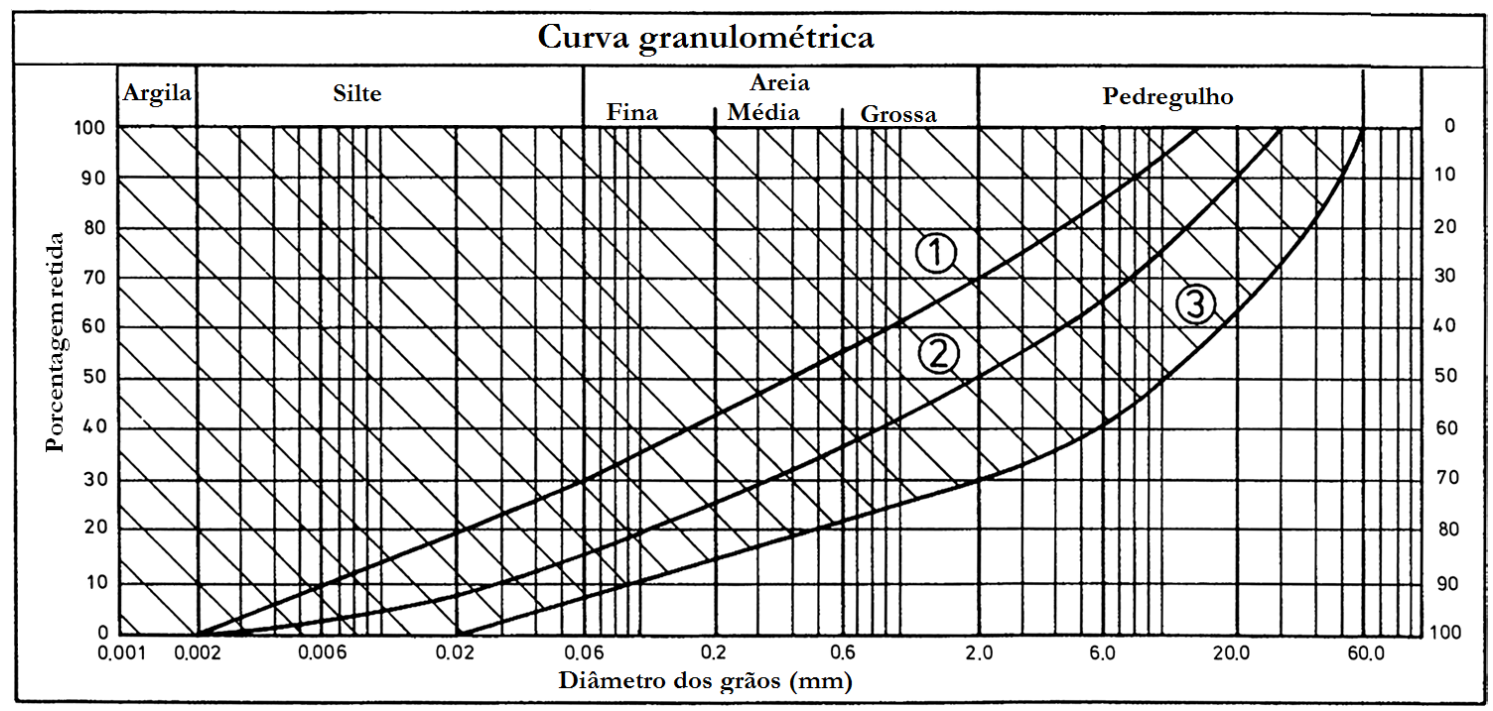

Fonte: adaptado de Maidl (1995, apud Maidl et al., 2012).

Na Figura 2.6 são definidas 3 regiões na curva granulométrica onde o TBM-EPB pode ser utilizado: região 1 - condições ótimas, condicionamento com água e tensoativos para evitar clogging; região 2: aplicável se $\mathrm{k}<10^{-5} \mathrm{~m} / \mathrm{s}$, condicionamento com espumas e polímeros; região 3: aplicável se $k<10^{-4} \mathrm{~m} / \mathrm{s}$ e sem pressão hidrostática, condicionamento com espumas e polímeros de alta densidade; abaixo da curva 3 a permeabilidade do terreno escavado é muita alta e não é possível garantir a aplicação de uma pressão de equilíbrio na frente de escavação.

Cabe destacar que os avanços recentes no desenvolvimento de aditivos para condicionamento da pasta na câmara de escavação têm permitido ampliar os limites de aplicação das máquinas do tipo EPB. Contudo, os custos associados à utilização intensa destes agentes condicionantes devem ser levados em consideração ao se avaliar a aplicabilidade de um tipo de máquina. Budach e Thewes (2015) introduzem uma extensão da faixa de aplicabilidade com base em testes de laboratório para verificar a viabilidade de se condicionar solos com distintas distribuições granulométricas. Adicionando condicionantes, os autores obtiveram propriedades adequadas das misturas em regiões da curva granulométrica além da faixa 3 
apresentada na Figura 2.6, com a ressalva de pressão hidrostática nula atuante nesta região. O novo limite proposto pelos autores é mostrado na Figura 2.7. $\mathrm{Na}$ mesma figura são representadas as curvas granulométricas limites (máximas e mínimas) de três projetos recentes no Brasil em que foram utilizadas máquinas do tipo EPB: Linha 4 do Metrô do Rio de Janeiro (de acordo com Maidl e Pierri, 2014), Linha 4 do Metrô de São Paulo (conforme Rocha et al., 2014) e Linha 5 do Metrô de São Paulo (Silva et al., 2016). Observa-se que as curvas máximas nos três projetos se situavam além da faixa 3 apresentada na Figura 2.6, contudo ainda dentro do novo limite proposto por Budach e Thewes (2015).

Figura 2.7 - Extensão da curva de aplicabilidade de EPB e faixas de curvas granulométricas de três projetos recentes no Brasil.

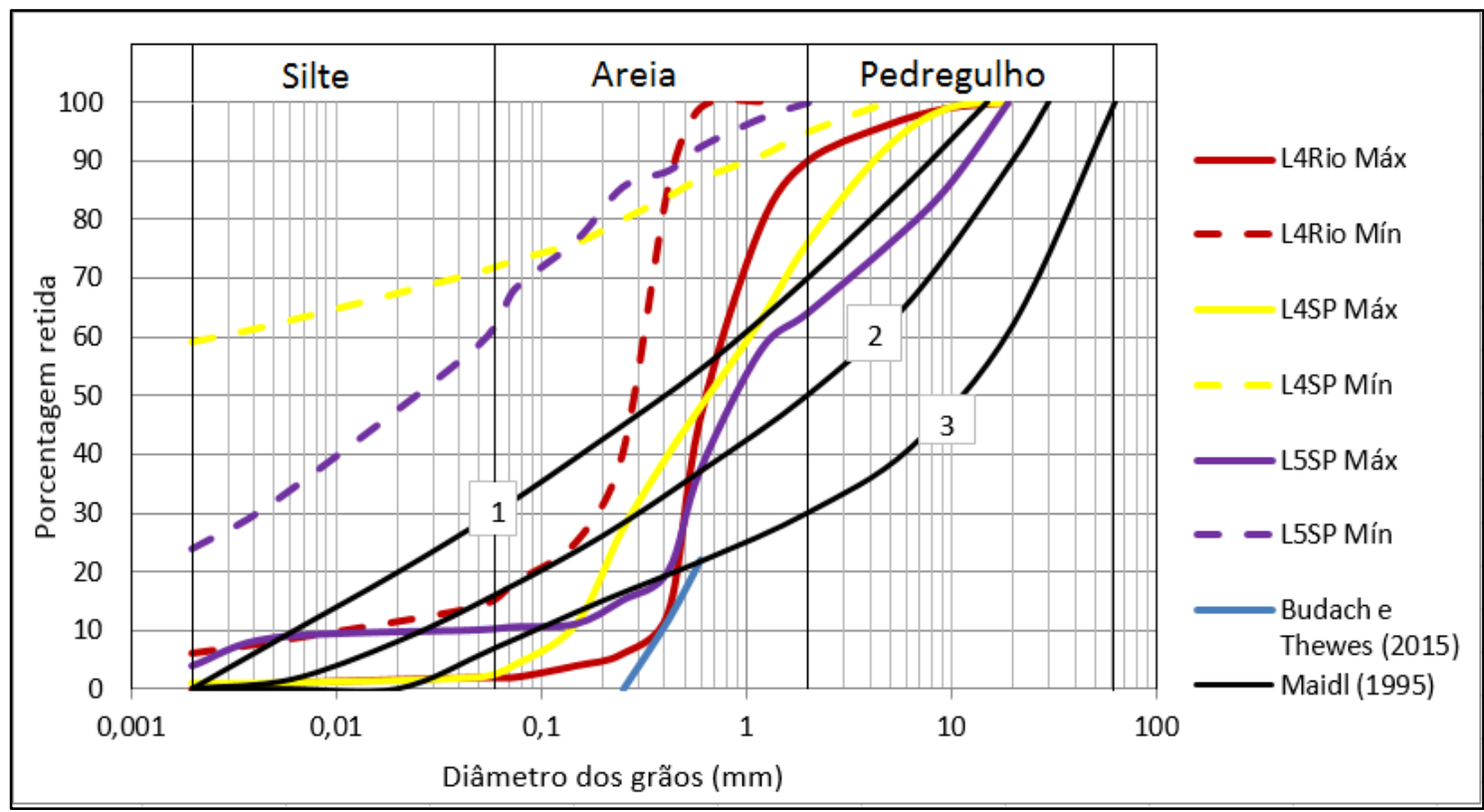

Fonte: adaptado de Maidl e Pierri (2014), Rocha et al. (2014) e Silva et al. (2016).

Com relação ao clogging que ocorre nas escavações em argila, a adesão deste tipo de solo no metal da cabeça de corte pode inviabilizar a escavação por obstrução nas ferramentas de corte, dificultando a penetração destas no maciço, e por fechamento das aberturas da cabeça de corte para entrada de material na câmara de escavação, sendo necessárias intervenções sob ar comprimido para limpeza e desobstrução da frente de escavação.

Hollmann e Thewes (2013) propões um gráfico para análise do potencial de adesão do solo em máquinas EPB, avaliado a partir dos limites de Atterberg, do índice de consistência $\left(I_{c}\right)$ e do índice de plasticidade $\left(I_{p}\right)$ do material (Figura 2.8). Cabe 
destacar que o gráfico foi desenvolvido com base em estudos de solos sedimentares do hemisfério norte, sua aplicabilidade para solos tropicais não foi verificada. Segundo os autores, a consistência e coesão do material definem a tendência de pedaços de solo se combinarem para formar blocos. Para evitar este tipo de problema, são adicionados tensoativos na câmara de escavação (conhecidos como anti-clay) e água. Outras soluções, que podem ser definidas no projeto da máquina, consistem em aumentar o tamanho e configuração das aberturas na cabeça de corte, alterar o tipo e a geometria das ferramentas de cortes e/ou prever injeção de jatos de água para limpar as aberturas sem necessidade de trabalhos manuais.

Figura 2.8 - Gráfico do potencial de adesão das argilas.

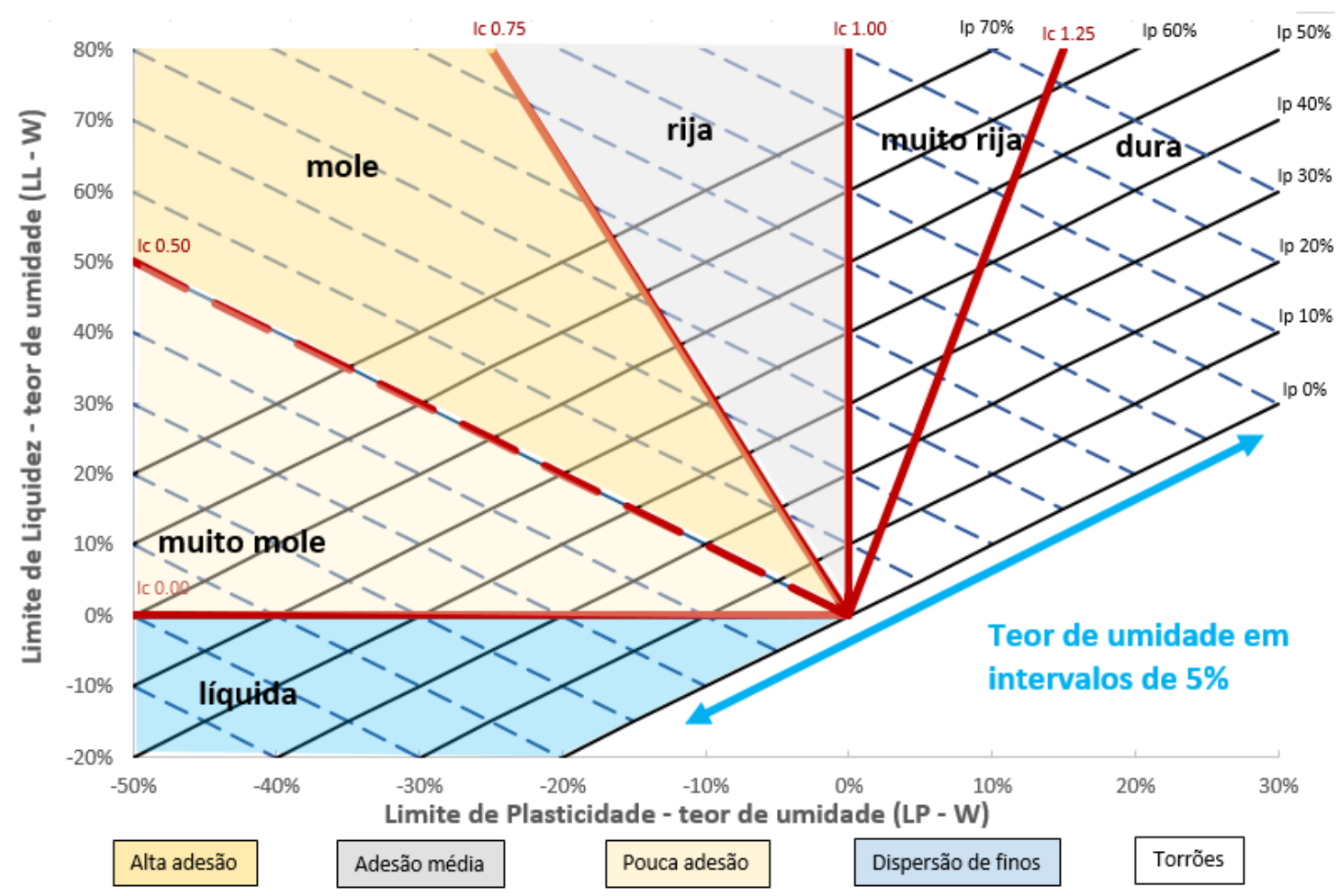

Fonte: adaptado de Hollmann e Thewes (2013).

$I_{p}=L L-L P$

$I_{c}=\frac{L L-w}{I P}$

Onde, $L L$ é o limite de liquidez, $L P$ é o limite de plasticidade e $w$ é a umidade natural do solo escavado.

Guglielmetti et al. (2008) destacam os principais pontos de atenção com relação ao tipo de solo escavado utilizando uma máquina do tipo EPB: homogenização da 
pasta formada na câmara de escavação entre o solo escavado e os aditivos acrescentados, para possibilitar a aplicação de uma pressão de equilíbrio na frente de escavação - para isso a trabalhabilidade e densidade da pasta devem ser controladas por meio de injeção de agentes condicionantes; controle da consistência e permeabilidade da pasta para que seja formado um gradiente de pressão no parafuso sem-fim, evitando assim entrada de água pelo parafuso e perda do controle da pressão da frente; em solos mais permeáveis, condicionamento com espumas e polímeros mais densos são necessários para que não haja dissipação da pressão de estabilização da frente para o terreno.

Observa-se, portanto, que o correto condicionamento do material escavado dentro da câmara de escavação é fundamental para garantir condições seguras de avanço com bom controle da pressão de frente. Além disso, um condicionamento eficiente deve proporcionar a redução do atrito interno do material na câmara para minimizar o torque na cabeça de corte e o desgaste das ferramentas de corte. Existem diversos aditivos para condionar o terreno, como espumas, polímeros e bentonitas. A escolha do tipo de aditivo a ser utilizado depende do tipo de solo escavado.

Bentonita é utilizada principalmente em máquinas do tipo Slurry, que necessitam de formação de cake e impregnação no solo para garantir a estabilidade. Em máquinas do tipo EPB, bentonita pode ser utilizada para aumentar a plasticidade do material escavado e reduzir sua permeabilidade. Já os polímeros são utilizados para modificar a viscosidade da pasta na câmara de escavação e aumentar a estabilidade da espuma em escavações em solo de alta permeabilidade, além de também reduzir a adesão de argilas. Polímeros são geralmente utilizados em combinação com espumas.

As espumas são utilizadas em máquinas EPB e são compostas por uma combinação de um líquido tensoativo misturado na água com ar, de maneira que o volume da mistura se expanda formando bolhas. A definição de dois parâmetros é fundamental para o controle da efetividade do condicionamento com espumas:

- razão de expansão da espuma (FER - foam expansion ratio): corresponde à relação entre o volume de espuma e o volume de líquido injetado. Varia em função do tipo de solo escavado - em argila utiliza-se espuma mais líquida (FER baixo), enquanto que em areia o FER é mais alto (espuma mais aerada). É definido pela 
relação apresentada na Equação (2.3), onde $V_{e}$ o volume total de espuma e $V_{l}$ o volume da parte líquida.

$F E R=\frac{V_{e}}{V_{l}}$

- razão de injeção de espuma (FIR - foam injection ratio): relaciona o volume de espuma injetada com o volume de solo condicionado - em solos granulares, mais permeáveis, utiliza-se FIR mais baixo. É dado pela Equação (2.4), onde $V_{s}$ é o volume de solo escavado.

$F I R=100 \cdot \frac{V_{e}}{V_{s}}$

Ensaios em laboratório podem ser realizados para verificar a qualidade do condicionamento do solo. O ensaio de abatimento do tronco de cone (slump test), conhecido para o controle do concreto fresco, é um bom parâmetro para verificar a trabalhabilidade do solo tratado. Vinai; Oggeri e Peila (2007) mostram que abatimentos entre 10 e $20 \mathrm{~cm}$ correspondem a trabalhabilidade adequada para aplicação em máquinas EPB. Na Figura 2.9 são ilustrados exemplos de testes de abatimento com distintas propriedades do condicionamento (variação de FIR e FER). Outros ensaios de laboratório interessantes de se realizar na mistura de solo com espuma sob diferentes parâmetros são: ensaios de permeabilidade (desejável permeabilidade inferior a $1 \times 10^{-5}$ ), densidade, compressibilidade (medindo a diferença no volume da mistura em um cilindro sob pressão atmosférica e ao se aplicar uma pressão de confinamento), resistência ao cisalhamento medida por ensaio de palheta (vane test) e estabilidade da mistura - colocando o solo condicionado em um cilindro e medindo o volume da mistura em diferentes momentos.

Figura 2.9 - Três exemplos de testes de abatimento: a) a mistura muito seca; b) mistura adequada; c) mistura muito fluída.
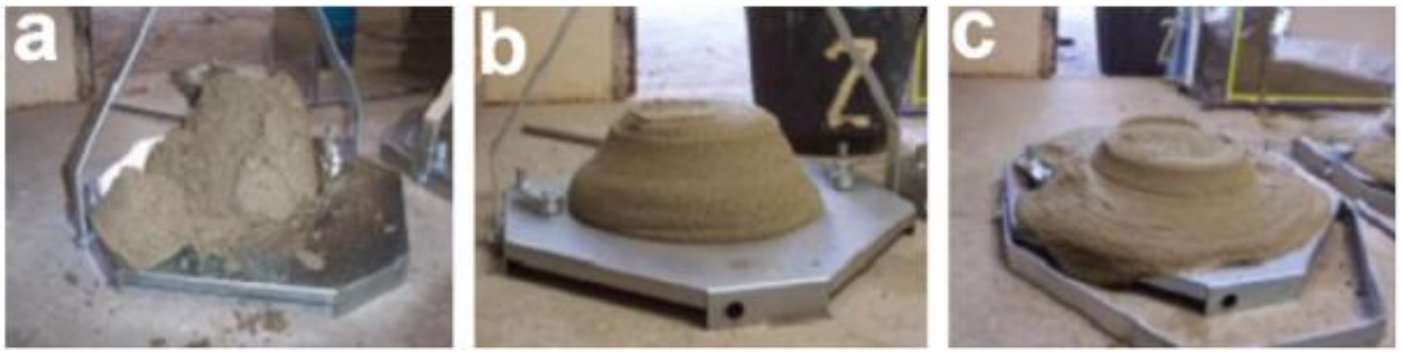

Fonte: Vinai; Oggeri e Peila (2007). 
Com relação à aplicabilidade de máquinas de lama (Slurry), estas são mais indicadas para maciços mais permeáveis. Yoshidawa (1982, apud Maidl et al., 2012) apresenta curvas limites no gráfico de curva granulométrica onde seria aplicável a escavação com este tipo de máquina, conforme Figura 2.10.

Figura 2.10 - Aplicabilidade de escavação com tuneladora de lama (Slurry-Shield).

Curva granulométrica

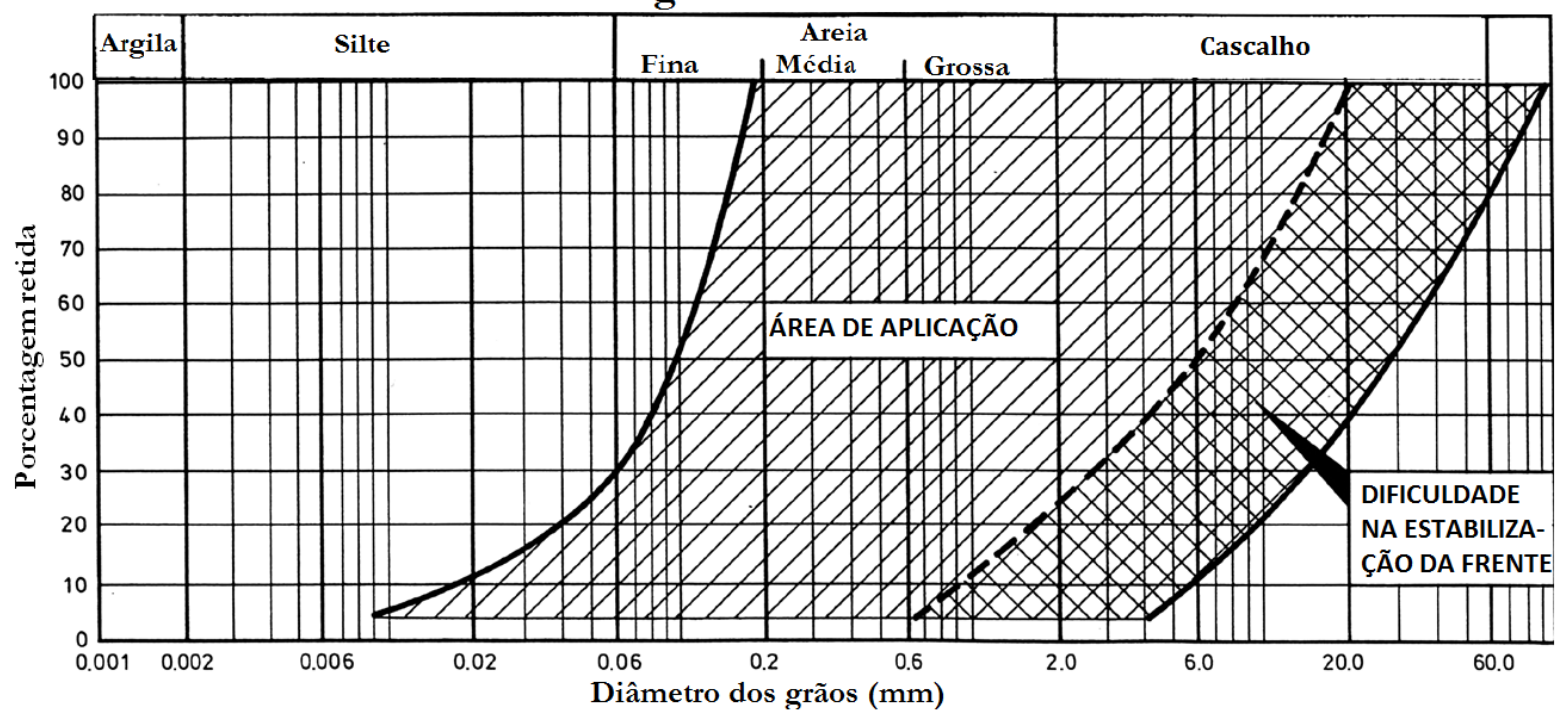

Fonte: adaptado de Yoshidawa (1982, apud Maidl et al., 2012).

Para utilizar este tipo de máquina, ensaios de penetração e impregnação de bentonita no maciço são fundamentais para a definição da concentração de bentonita a ser utilizada, assim como avaliar a formação do filter cake levando em conta o solo a ser escavado. Outra maneira de estimar a distância final de penetração de bentonita no terreno é pela Equação (2.5), definida empiricamente e apresentada na norma DIN 4126.

$e_{\text {máx }}=\frac{\Delta p \cdot d_{10}}{2 \tau_{f}}$

Onde:

$e_{\text {máx }}$ é a distância final de penetração da bentonita;

$\Delta p$ é a diferença entre a pressão de frente e a pressão hidrostática na frente; $d_{10}$ é o diâmetro característico solo $(\mathrm{d}<10 \%$;

$\tau_{f}$ é a resistência ao cisalhamento da mistura, que depende da concentração de bentonita. 
Na Figura 2.10, o limite à direita da área de aplicação é devido à alta permeabilidade dos solos granulares, o que dificulta a formação do cake e pode ocasionar dissipação da lama bentonítica para o terreno, o que ocorre em solos com permeabilidade acima de $5 \times 10^{-3} \mathrm{~m} / \mathrm{s}$, segundo Maidl et al. (2012). Além disso, cascalhos e pedregulhos de maior diâmetro podem dificultar o bombeamento da mistura escavada. Já o limite inferior da curva está relacionado ao entupimento que solos argilosos provocam nas aberturas da roda de corte, além da dificuldade de separação das partículas finas do solo da bentonita, que deve ser reutilizada no processo de escavação. Assim como no caso das máquinas EPB, existem aditivos desenvolvidos recentemente à base de finos que permitem melhorar as propriedades reológicas da mistura e ampliar a faixa de aplicabilidade das máquinas do tipo Slurry.

\subsubsection{Princípio de funcionamento}

Como mencionado anteriormente, uma das principais características das máquinas tuneladoras é a utilização de escudos para suporte provisório do solo e de uma cabeça de corte rotativa com diferentes tipos de ferramentas de corte para promover a escavação. Nas tuneladoras atuais, a própria máquina instala os revestimentos, que são usualmente anéis fechados constituídos por aduelas de concreto prémoldado reforçadas com armadura convencional, fibras de aço ou uma solução mista dos dois componentes. Cada anel é fechado durante a montagem utilizando o chamado segmento chave, que possui bordas inclinadas para facilitar sua colocação. Para evitar problemas de percolação de água pelas juntas, uma vez que os anéis já são o revestimento definitivo do túnel e são responsáveis pela sua estanqueidade, busca-se montar anéis subsequentes com a posição das juntas entre os segmentos deslocadas, conforme apresentado na Figura 2.11.

Há dois tipos de juntas no revestimento: as juntas longitudinais são aquelas entre dois segmentos do mesmo anel e as juntas radiais ou circunferenciais estão entre dois anéis subsequentes. A ligação transversal entre os segmentos usualmente se dá por parafusos metálicos, enquanto que a ligação entre anéis é feita por conectores plásticos com encaixe ou parafusos para restringir o deslocamento. No contato entre os anéis são utilizados também "pads" de madeira ou betuminosos de 
espessura entre 2 e $4 \mathrm{~mm}$ para regularizar a superfície de contato e transferir apropriadamente entre os anéis a força longitudinal de avanço aplicada pelos cilindros de empuxo da máquina. Além disso, para garantir a impermeabilização do revestimento são utilizados perfis estrudados de borracha, que, ao serem pressionados durante a instalação dos segmentos, devem suportar a pressão hidrostática atuante.

Figura 2.11 - Sequência de instalação dos segmentos. À esquerda em perspectiva, à direita vista desenvolvida.

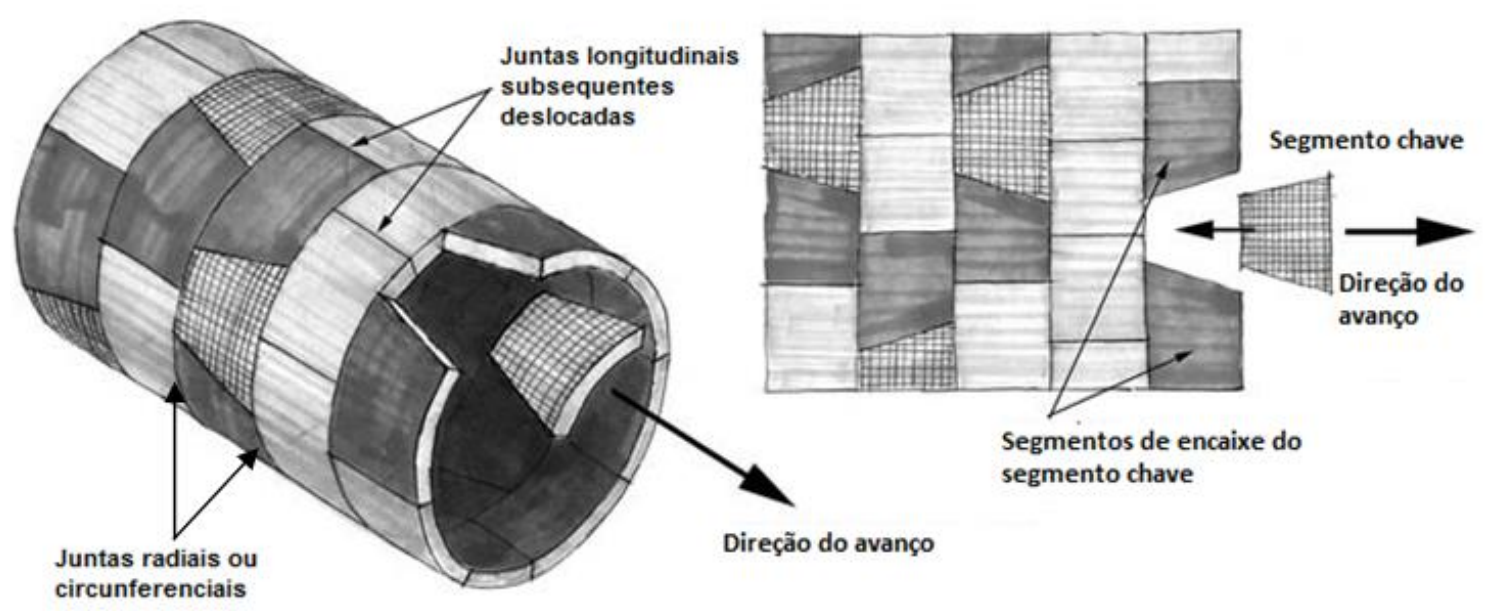

Fonte: adaptado de Kolymbas (2005).

Para permitir a realização de curvas, os anéis dispõem de uma conicidade, ou seja, existe uma diferença milimétrica entre a máxima e a mínima largura dos segmentos. Esta diferença é calculada com base no raio mínimo de curva que a máquina deverá escavar, definido no traçado geométrico. A colocação dos segmentos durante a escavação leva em conta o traçado geométrico e a conicidade de cada segmento do anel. A conicidade é calculada de acordo com a Equação (2.6), conforme indicado na Figura 2.12.

Figura 2.12 - Representação de um anel em planta (sem escala) indicando as dimensões necessárias para definição da conicidade.

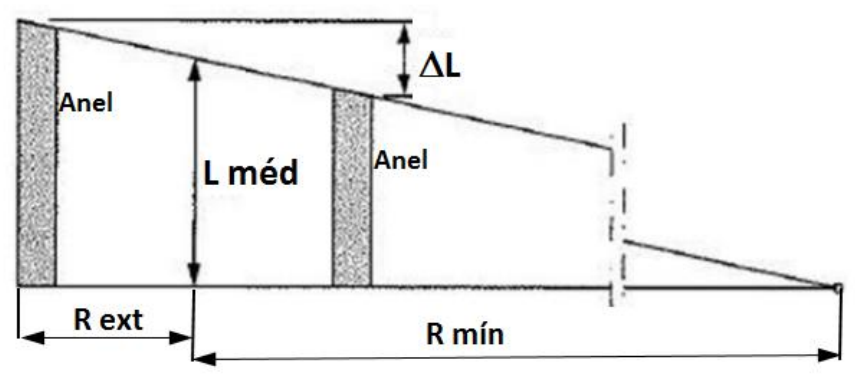


$\Delta L=\frac{R_{\text {ext }} \cdot L_{\text {méd }}}{R_{\min }}$

Onde $\Delta L$ é a conicidade a ser utilizada, $R_{\text {ext }}$ é o raio externo do anel, $L_{\text {méd }}$ é o comprimento médio do anel e $R_{\min }$ é o raio mínimo definido no traçado geométrico.

O avanço da máquina ocorre por meio da propulsão de macacos hidráulicos (chamados de cilindros de empuxo) localizados na parte traseira do escudo e distribuídos perifericamente para se apoiar nos anéis de revestimento já instalados. Estes macacos têm um curso de avanço superior à largura dos anéis do revestimento. Uma vez terminado o avanço da escavação, os macacos retraem-se para a colocação de um novo anel do revestimento.

Para controlar a direção do avanço da máquina, cada macaco pode funcionar independentemente ou em grupo. Uma abertura maior dos cilindros de avanços de um lado da máquina determinará o avanço da escavação para o lado oposto. As máquinas modernas possuem ainda articulações no escudo, para permitir fazer curvas de raio menor e com menos atrito no terreno circundante. Na Figura 2.13 são apresentadas as principais partes de uma máquina TBM, neste caso uma máquina do tipo EPB.

Figura 2.13 - Apresentação das principais partes de uma máquina TBM-EPB.

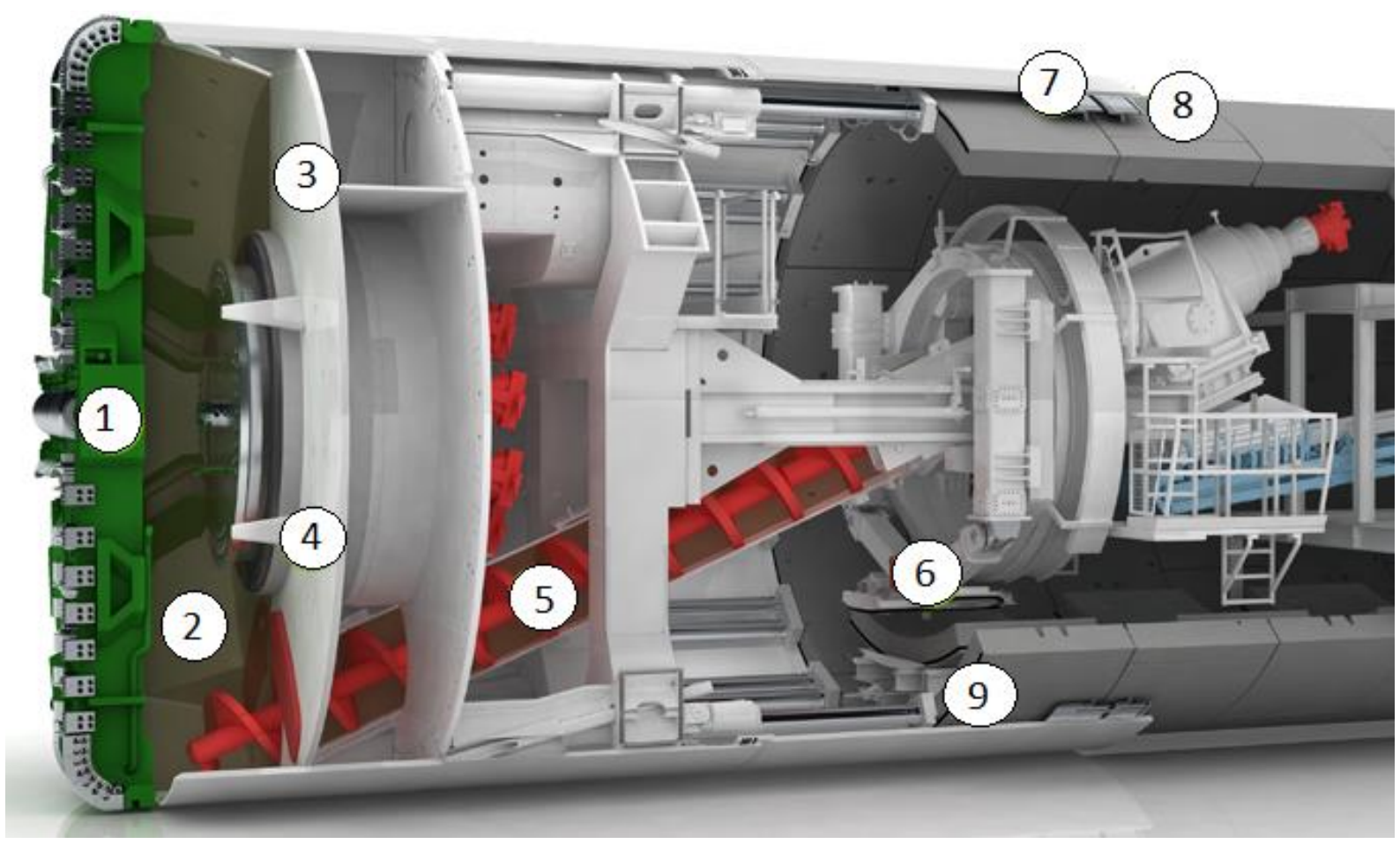

Fonte: www.herrenknecht.com. 
1 - Roda de corte: ferramentas de corte para escavação do solo;

2 - Câmara de escavação: a mistura de solo escavado com aditivos (pasta) transfere a pressão de estabilização necessária para a frente de escavação;

3 - Anteparo da câmara pressurizada (bulkhead): transfere a força de empuxo à pasta de solo na câmara de escavação, onde há sensores para registro das pressões em diversas alturas;

4 - Braços de agitação: misturam o solo na câmara de escavação para auxiliar a obter a textura necessária para a formação de uma boa pasta;

5 - Parafuso sem fim: a velocidade de rotação determina quanto material é removido da câmara de escavação, regulando assim a pressão de suporte da frente;

6 - Eretor: é um manipulador controlado remotamente que posiciona os segmentos durante a montagem dos anéis de revestimento;

7 - Escudo: proteção perimetral da escavação. Escovas selam o espaço entre a face interna do escudo e o extradorso do anel de revestimento;

8 - Anéis de revestimento: composto por segmentos pré-moldados de concreto;

9 - Cilindros de empuxo: responsáveis pela aplicação da força de avanço da escavação. Sua extensão deve ser superior à largura do segmento.

O diâmetro de escavação deve ser maior do que o diâmetro externo dos anéis de revestimento, pois estes são montados ainda dentro do escudo. Além disso, também é prevista uma folga de aproximadamente $10 \mathrm{~cm}$ entre os anéis e o escudo da máquina, para facilitar sua instalação e também possibilitar correções no alinhamento da escavação sem exercer carregamentos excessivos nos anéis. Por conta disso, um vazio é continuamente gerado atrás do escudo, denominado espaço anelar. Para preencher este vazio entre 0 anel e 0 terreno, é realizada permanentemente durante o avanço injeção de grout sob pressão (Figura 2.14).

Figura 2.14 - Injeção de grout para preenchimento do espaço anelar.

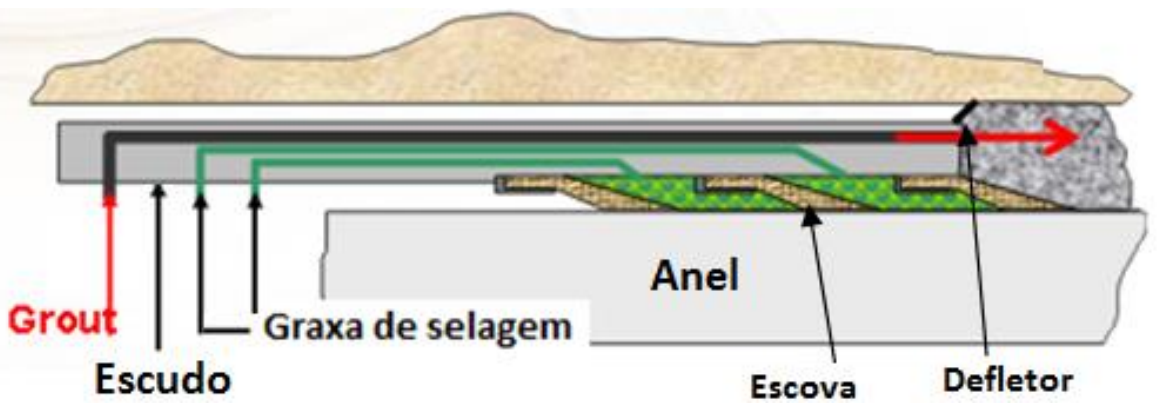

Fonte: adaptado de Guglielmetti et al. (2008). 
Este grout pode ser composto por um bicomponente com tempo de endurecimento controlado ou calda de cimento com pega rápida. Uma das principais funções do grout é preenchimento do espaço anelar para transmitir os esforços entre os anéis de revestimento e o maciço e para manutenção do estado de tensões naturais do solo. Para garantir esta condição, a resistência do grout deve ser no mínimo superior à resistência do solo. Outras propriedades importantes de serem garantidas no grout são a resistência ao cisalhamento e o módulo de elasticidade, o primeiro para garantir adequada ligação entre o anel e o solo e o segundo para evitar deformações excessivas.

Na Figura 2.14, observa-se também algumas outras características importantes do funcionamento da máquina. Durante a injeção do grout, há concomitantemente a injeção de uma graxa de selagem entre os conjuntos de escovas, para evitar que o grout entre na máquina, pois sua injeção é sob pressão acima da pressão atmosférica. Na parte final do escudo há o defletor, que evita que o grout injetado vá para a frente da máquina. Além disso, destaca-se que no final do escudo há um espaço entre este e o terreno. Isto ocorre porque o escudo é projetado ligeiramente cônico para reduzir seu atrito com o terreno. Esta conicidade em geral é inferior a 10 cm no diâmetro.

\subsubsection{Estabilização da frente e controle das deformações}

Com relação ao controle das deformações induzidas pela escavação de túneis com TBMs, dois fatores desempenham papel fundamental: preenchimento efetivo do vazio anelar e aplicação da pressão de frente para estabilização do maciço. Com relação ao primeiro ponto, conforme ilustrado na Figura 2.14, é importante garantir a injeção do volume correto de grout durante o avanço (volume este definido pela diferença entre o diâmetro da escavação e o diâmetro externo do anel), com injeções a pressões adequadas, no mínimo superiores à pressão de frente. A injeção do volume correto de grout também é fundamental para garantir o confinamento do anel e reduzir assim esforços solicitantes nas peças provenientes de carregamentos diferenciais no perímetro do anel.

No que diz respeito ao controle da estabilidade da frente de escavação, as máquinas com a frente fechada pressurizada têm a vantagem da possibilidade de aplicação de 
uma pressão na frente que estabiliza o terreno. Em máquinas do tipo EPB, a pressão de frente é controlada pela velocidade de rotação do parafuso sem fim, por onde se controla o volume de solo que é extraído da câmara pressurizada. Desta maneira, na câmara de escavação é aplicada uma pressão que deve equilibrar o empuxo do solo e da água (Figura 2.15). Além de garantir as condições de equilíbrio e estabilidade da frente de escavação, a aplicação de pressão na frente também tem o objetivo de controlar o desenvolvimento de deformações no maciço.

Figura 2.15 - Estabilização do terreno pela aplicação de pressão de frente.

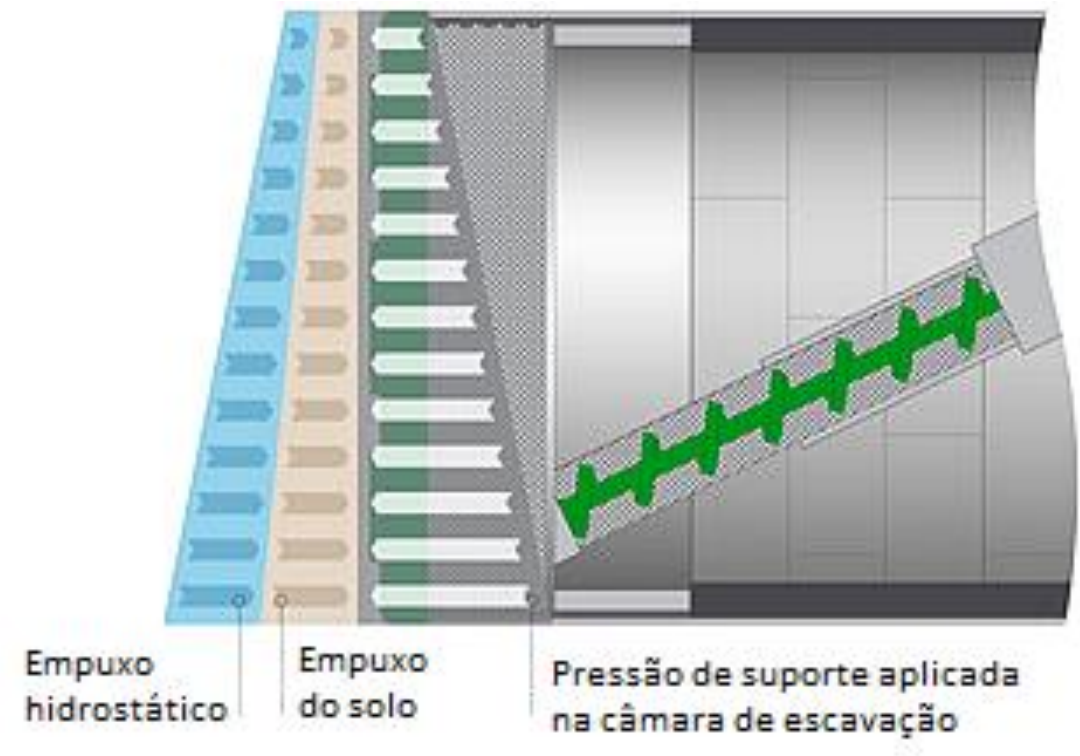

Fonte: adaptado de Guglielmetti et al. (2008).

\subsubsection{Modos de operação e controles dos parâmetros operacionais de uma tuneladora EPB}

Uma das principais vantagens de uma tuneladora do tipo EPB é sua flexibilidade para escavação em diferentes condições e tipos de solo. A operação de uma tuneladora se aproxima de um processo industrial, com elevado grau de automação e diversas atividades ocorrendo concomitantemente durante a escavação. Para o sucesso da escavação, é fundamental que haja um bom controle dos principais parâmetros operacionais. Existem três maneiras distintas de operar a máquina de acordo com as condições da frente de escavação (Figura 2.16):

- Modo fechado: trata-se da aplicação plena da pressão de terra balanceada. A câmara fica completamente preenchida com o próprio material escavado (condicionado com adições para homogeneizá-lo), que é usado para aplicar a 
pressão de frente contra o solo. Recomendada para escavação em solos instáveis ou com alta pressão hidrostática.

- Modo de transição (semi-aberto): consiste em um preenchimento parcial da câmara de frente com material escavado, mantendo uma bolha de ar-comprimido na parte superior da câmara. Este modo é indicado para escavação em solo competente, já que a bolha de ar pode não ser suficiente para estabilizar a parte superior da frente de escavação. Para contornar este problema, sistemas recentes têm utilizado uma tecnologia híbrida, onde converte-se o sistema EPB para um sistema do tipo Slurry, com adição de bentonita na frente. Maidl et al. (2016) relatam a experiência de conversão de máquina EPB em híbrida durante a escavação da Linha 4 do Metrô do Rio de Janeiro. Ressalta-se, contudo, que é necessário que a máquina disponha de maquinário previamente instalado para possibilitar a conversão.

- Modo aberto: utilizado em rocha ou em solo autoportante sem ou com pouca presença de água na frente de escavação. A câmara de frente fica vazia, ou seja, não há acúmulo de material na câmara para pressurizar a frente, todo material escavado é logo retirado pelo parafuso sem-fim. É possível a aplicação de arcomprimido para pressurizar a frente em passagens com baixa pressão hidrostática.

Figura 2.16 - Modos de operação de uma tuneladora EPB.
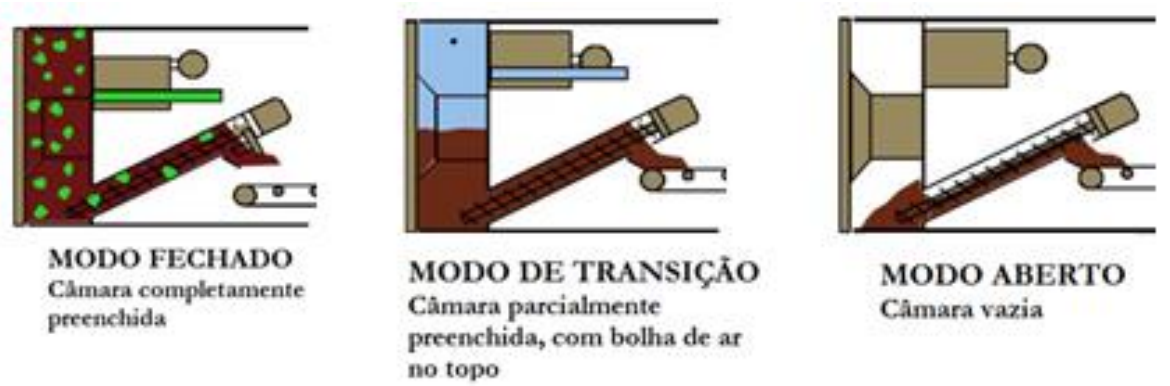

Fonte: adaptado de Guglielmetti et al. (2008).

Diferentemente de túneis convencionais, onde a visualização e o mapeamento da frente da escavação são essenciais, em escavações mecanizadas é necessário um conhecimento sobre a operação da máquina e o controle em tempo real dos principais parâmetros operacionais. Além disso, a alta velocidade de escavação, que pode chegar a até $30 \mathrm{~m}$ por dia, não permite que se dependa exclusivamente da análise da instrumentação superficial para adequar os parâmetros de escavação, é preciso ter dados em tempo real do desempenho da máquina para a tomada de decisões visando garantir a segurança da escavação. Aguiar et al. (2017) 
apresentam os principais parâmetros que devem ser controlados durante a escavação dentre os quais, destacam-se:

- pressão de frente: fundamental para garantir a estabilidade da escavação e mitigar recalques superficiais;

- pesagem: o material que é retirado da câmara de escavação é pesado dinamicamente durante o avanço. Conhecendo-se o peso específico do material escavado, é possível estimar o volume de solo escavado durante um avanço. Tratase do principal controle para se detectar possíveis sobreescavações;

- volume e pressão da injeção de grout: é o controle mais importante para se garantir o correto preenchimento do espaço anelar e evitar recalques superficiais;

- condicionamento: consiste na definição dos parâmetros FER e FIR, que devem ser constantemente ajustados de acordo com o material que está sendo escavado, observando o material que sai pela esteira, de maneira que se tenham sempre um material homogêneo e trabalhável na frente de escavação;

- densidade aparente na câmara de escavação: na câmara de escavação são dispostos sensores fixados em diferentes alturas para o controle da pressão de frente. A densidade aparente é calculada como a razão entre as diferenças de pressões medidas em dois sensores e sua distância vertical. Como não é possível visualizar a frente nem a câmara de escavação durante o avanço, o controle do nível de preenchimento da câmara é feito por meio do acompanhamento da densidade aparente em diferentes alturas.

\subsection{COMPARAÇÃO ENTRE ESCAVAÇÃO MECANIZADA E ESCAVAÇÃO TRADICIONAL (MÉTODO SEQUENCIAL)}

Estudos que avaliam a metodologia de escavação convencional, o método sequencial, foram desenvolvidos nos últimos anos, conforme indicado adiante na Tabela 4-1. Nestes trabalhos é possível consultar mais detalhes a respeito desta metodologia, que já está consagrada mundialmente e vem sendo utilizada constantemente nas últimas décadas.

A escolha entre escavação com máquinas tuneladoras ou pelo método convencional requer a avaliação de diversos critérios. Nos últimos anos, a utilização de TBMs vem aumentando em todo o mundo, devido principalmente às evoluções tecnológicas das máquinas que ampliaram sua aplicabilidade. Por outro lado, escavações pelo 
método tradicional têm ficado restritas a maciços com condições muito favoráveis (demandam pouco condicionamento do maciço e controle da água subterrânea) muito desfavoráveis (onde o controle da pressão de frente e homogeneização do material escavado na câmara possa ser problemático) ou com muita variabilidade, em túneis curtos ou em túneis com variação de seção transversal. A seguir são apresentados alguns critérios e comparações entre as duas metodologias. Destacase mais uma vez que estão contempladas somente escavações em solo ou rocha branda. Escavações em rocha e comparações com a metodologia drill and blast não foram abordadas.

- Segurança: escavações mecanizadas apresentam maior nível de segurança para os trabalhadores do que escavações tradicionais, devido a fatores como: menor exposição ao risco, já que em TBMs os trabalhadores transitam somente onde o revestimento já está instalado ou sob o trecho em que o escudo metálico suporta o terreno, enquanto que no método sequencial os trabalhadores precisam ficar próximos à frente de escavação aberta; o alto grau de padronização e mecanização das máquinas tuneladoras também é um ponto positivo. Já na escavação convencional, o trabalho é mais manual e mais dependente da experiência humana.

- Recalques e danos a edificações: em escavações mecanizadas, devido ao controle que se tem da pressão aplicada na frente de escavação propiciado pelas máquinas mais recentes, os recalques superficiais são mínimos se os parâmetros de escavação forem bem definidos e a operação ocorrer sem dificuldades. No método tradicional, dependendo do tipo de solo escavado, é esperado maior nível de recalque superficial, devido ao tempo necessário para a instalação do suporte primário e do fechamento da seção, além do fato de que a escavação em pressão atmosférica proporciona um alívio de tensões no maciço que resulta em deformações naturais no terreno. Nos casos de túneis convencionais, há ainda o agravante do adensamento ocasionado pelo necessário rebaixamento do nível d'água em túneis escavados abaixo do lençol freático, o que não é necessário em túneis mecanizados. Comparando-se o desempenho das duas metodologias executivas em escavações na Bacia Sedimentar de São Paulo, Bilfinger et al. (2013) registram perda de solo média de $0,28 \%$ e perda de solo máxima de $1,42 \%$ na escavação mecanizada da Linha 4 do Metrô de São Paulo, enquanto que Negro; Sozio e Ferreira (1992) relatam perda de solo média de $0,89 \%$ e máxima de $2,4 \%$ 
em escavações convencionais (valores correspondentes às escavações na Bacia Sedimentar de São Paulo).

- Estrutura de suporte: nos túneis mecanizados o suporte instalado já é o definitivo, ou seja, os revestimentos primário, secundário e a impermeabilização já são executados em uma só fase, o que não acontece em túneis convencionais. Além disso, a seção circular dos túneis mecanizados favorece a distribuição de tensões no revestimento sob condições isotrópicas, resultando em menores esforços de flexão. Por outro lado, a seção circular pode ser desfavorável em condições de tensões anisotrópicas - o método convencional apresenta a vantagem de permitir otimizar a seção de escavação em função das condições do solo escavado. Nos anéis de revestimento da escavação mecanizada, a presença das juntas entre aduelas resulta também na redução dos esforços de flexão. Em túneis convencionais, alguns projetos desconsideram o revestimento primário durante o dimensionamento do revestimento secundário (definitivo), devido a fatores como a incerteza da qualidade de execução da concretagem e da espessura final do revestimento. Isto resulta em estruturas finais mais pesadas quando comparadas com o revestimento em anéis pré-fabricados em túneis mecanizados. Contudo, quando o revestimento secundário é dimensionado junto com o revestimento primário, a espessura final pode ser inferior à espessura de um anel sob as mesmas condições.

- Velocidade de construção: as taxas de avanços na escavação mecanizada tendem a ser superiores às do método convencional. Bilfinger et al. (2013) relatam velocidade máxima de $33 \mathrm{~m} /$ dia e velocidade média de $13 \mathrm{~m} /$ dia na escavação mecanizada da Linha 4 do Metrô de São Paulo. No caso de túneis convencionais, a velocidade de avanço depende da realização ou não de tratamentos no maciço e parcializações da seção de escavação. Negro; Sozio e Ferreira (1992) citam velocidades máximas de $13 \mathrm{~m} /$ dia na escavação pelo método convencional na Linha 2 do Metrô de São Paulo. Bilfinger et al. (2013) sugerem velocidades médias de 1 m/dia em estimativas preliminares de túneis convencionais. Para escavações mecanizadas, a infraestrutura necessária para início da operação é muito maior do que no método convencional, o que tende a postergar o início de uma escavação. Por outro lado, em escavações convencionais há a possibilidade de serem abertas diversas frentes de ataque e com escavação em diferentes sentidos, o que possibilita reduzir o tempo de execução de um túnel. 
- Seção de escavação: as escavações mecanizadas, salvo com algumas máquinas específicas, são limitadas à seção circular. Em túneis rodoviários e metroviários esta seção demanda uma maior área de escavação e um enchimento posterior é necessário para garantir o gabarito útil, gerando assim maiores custos. Já na metodologia sequencial é possível ter a liberdade para otimizar a área escavada, dada a flexibilidade geométrica da seção de escavação. Graças a esta flexibilidade, é possível também executar túneis com curvas de raios menores. Por outro lado, na escavação com tuneladora se obtém maior precisão na escavação da área determinada, enquanto que em escavações pelo método sequencial é mais comum a ocorrência de sobreescavações e desplacamentos localizados, o que gera acréscimos de custo.

- Custo: ao comparar custos entre as metodologias, deve-se levar em conta que em escavações mecanizadas os custos com equipamento e instalações iniciais são mais altos, o que torna esta metodologia economicamente viável somente a partir de determinada extensão de túnel. Segundo estimativa de Sauer (2003), em túneis com extensão inferior a 1600 metros em geral a execução de túneis convencionais é vantajosa, enquanto que para túneis com mais de 3200 metros a escavação mecanizada tende a levar vantagem. Em extensões intermediárias, é necessário avaliar as condições geológicas e de campo para definir a metodologia mais em conta. Com relação à escavação mecanizada, é importante destacar também que qualquer problema ou dificuldade com o equipamento resulta em uma parada total da escavação, demandando em geral maiores custos e tempos para manutenção quando comparados com os reparos dos equipamentos utilizados em escavações tradicionais, que são mais usuais e facilmente substituíveis.

- Condições do maciço: a escavação mecanizada apresenta como vantagem a possibilidade de escavação abaixo do lençol freático sem medidas adicionais, enquanto que na metodologia tradicional é necessário prever atividades complementares como rebaixamento do lençol freático ou tratamento do maciço para garantir a estabilidade da escavação abaixo do nível d'água, o que afeta o custo e prazo de execução das obras. Entretanto, a adaptabilidade da metodologia tradicional a diferentes tipos de solos escavados é mais fácil, já que em TBMs condições geológicas extremas podem inviabilizar a escavação, como, por exemplo, nos limites apresentados nas Figura 2.6 e Figura 2.10. A metodologia tradicional 
possibilita a variação da parcialização da escavação com mais facilidade, assim como a execução de tratamentos de maciço que inicialmente não haviam sido previstos. 
3 COMPORTAMENTO DO MACIÇO DURANTE A ESCAVAÇÃO DE UM TÚNEL 


\section{COMPORTAMENTO DO MACIÇO DURANTE A ESCAVAÇÃO DE UM TÚNEL}

Este item apresenta alguns conceitos relacionados a escavações de túneis em maciços de solo, reunindo algumas definições mostradas por França (2006), Cecílio (2009), Silva (2008) e Marques (2006). A seguir será apresentada uma revisão bibliográfica a respeito de análises de estabilidade da frente da escavação, deformações induzidas no maciço e esforços no revestimento em escavações mecanizadas.

A escavação de um túnel em um maciço previamente em equilíbrio resulta na remoção das tensões ao longo da região escavada, ocasionando um rearranjo do estado de tensões no maciço até que um novo estado de equilíbrio seja alcançado. Portanto, à medida que a frente de escavação do túnel avança, há uma importante alteração do campo de tensões do maciço envolvente.

A estabilização das deformações pode ser atingida a partir de duas maneiras distintas: com a mobilização parcial ou total da resistência do solo, em um maciço que apresenta a capacidade de suportar o descarregamento ocasionado pela remoção das tensões no contorno da escavação com deformações limitadas e em condição de estabilidade (maciço autoportante); ou com o auxílio de um sistema de suporte, nos casos em que o maciço não se estabiliza após a mobilização total de sua resistência ou para controlar grandes deformações associadas à alteração do estado de tensão.

As deformações que ocorrem no maciço durante o processo de escavação e instalação do revestimento resultam em redistribuições de tensões para as regiões adjacentes à escavação, o que se denomina arqueamento de tensões. Trata-se de um fenômeno que ocorre tridimensionalmente, representado esquematicamente na Figura 3.1. Em uma avaliação no sentido longitudinal da escavação, o arqueamento é responsável pela transferência de tensões da região escavada sem suporte para o maciço à frente ainda não escavado e para o suporte situado atrás da frente de escavação.

O arqueamento de tensões ocorre quando há a mobilização da resistência ao cisalhamento do maciço envolvente à abertura realizada, conforme representado na Figura 3.2, onde está indicado que deslocamentos diferenciais entre os elementos 
induzem tensões de cisalhamentos entre eles. Um dos mecanismos de colapso de um túnel corresponde à incapacidade do maciço de mobilizar esta resistência ao cisalhamento.

Figura 3.1 - Arqueamento tridimensional das tensões.
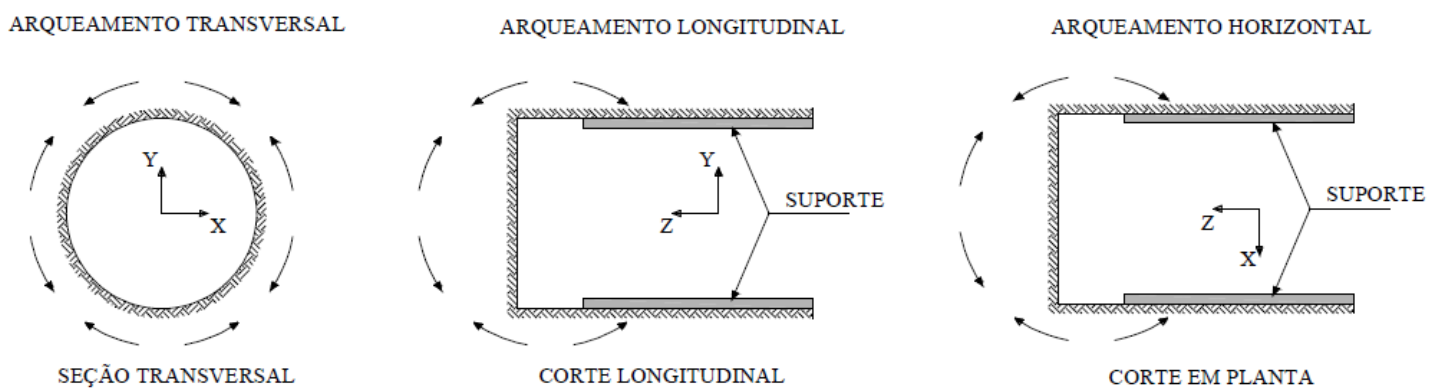

Fonte: adaptado de Silva (2008).

Figura 3.2 - Mobilização da resistência ao cisalhamento do maciço devido ao arqueamento das tensões.
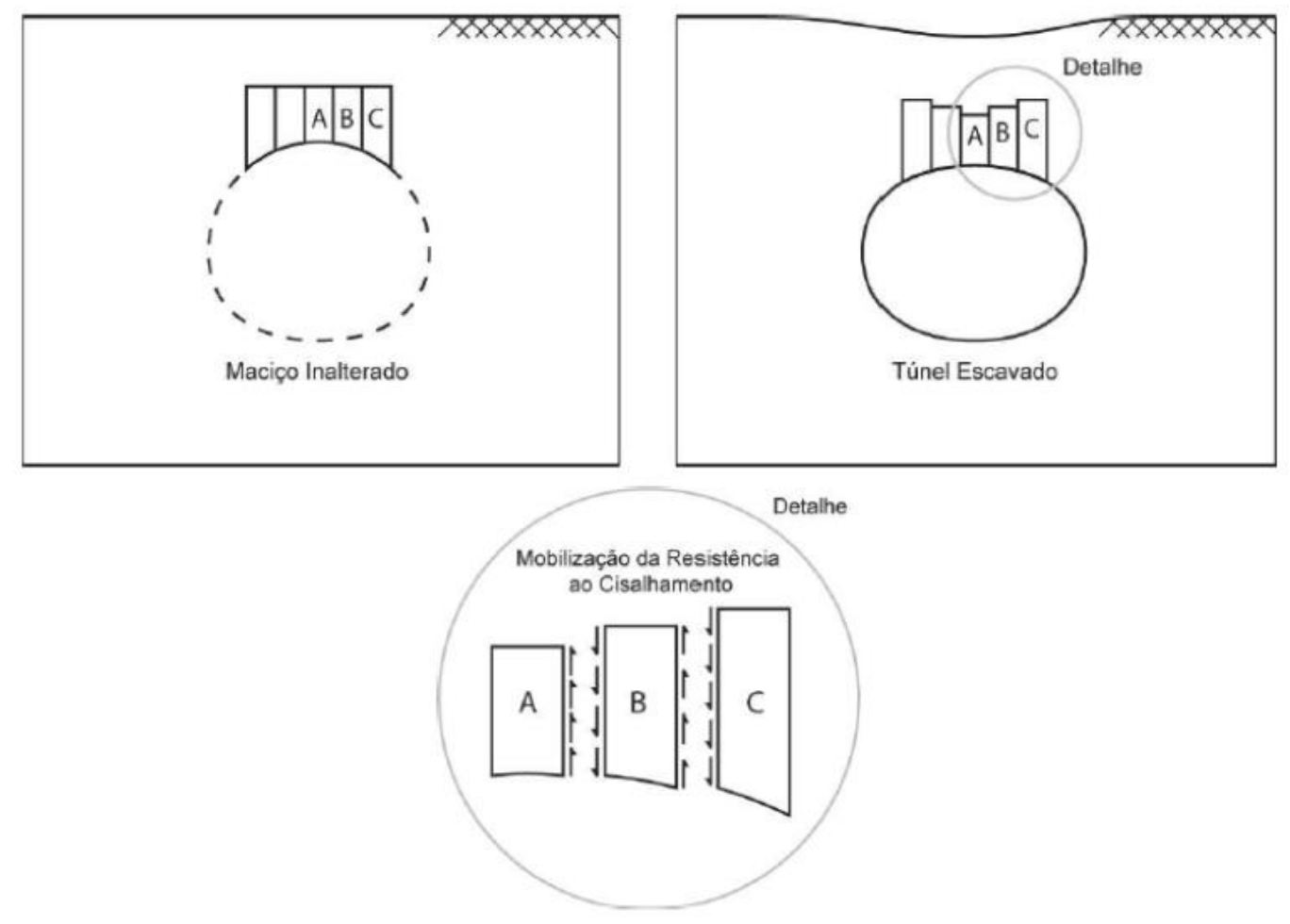

Fonte: França (2006).

Uma maneira de observar o arqueamento de tensões é a partir da avaliação das direções principais das tensões do maciço antes e após a escavação do túnel. Considerando uma situação em que antes do início da escavação de um túnel a direção das tensões principais maiores e menores coincidem com os eixos verticais e horizontais, ou seja, não existem tensões de cisalhamento atuando nestes planos. 
Após a escavação, o efeito do arqueamento mobiliza tensões cisalhantes nos arredores da abertura, fazendo com que ocorra uma rotação da direção das tensões principais (Figura 3.3), uma vez que os planos com cisalhamento nulo não são mais os planos verticais e horizontais.

Figura 3.3 - Alteração da direção das tensões principais antes e após a escavação de um túnel.

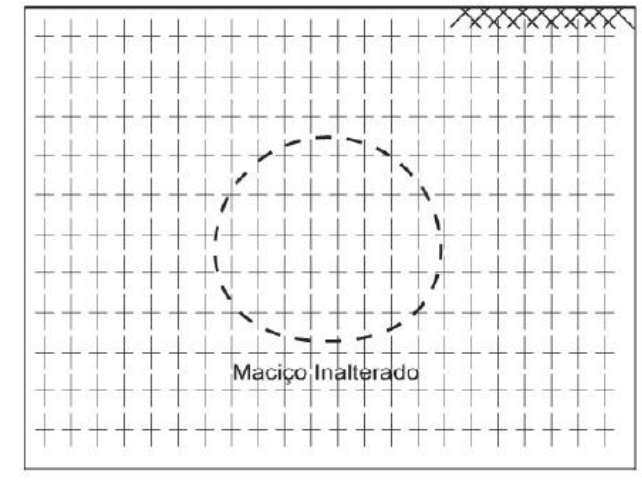

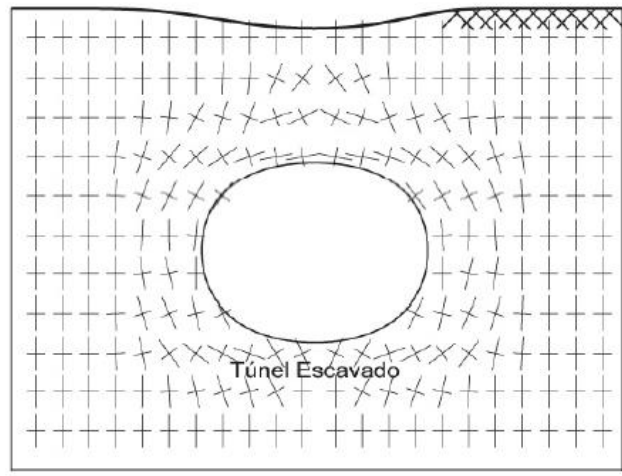

Fonte: França (2006).

O estado de deformação do maciço é de natureza tridimensional e quanto menor a resistência do maciço, maior é o desenvolvimento de zonas plastificadas e maior é a distância da frente de escavação onde as deformações induzidas no terreno se estabilizam. Já com relação ao sistema de suporte, quanto mais rígido e mais rápido este for instalado, mais rápido ocorre o rearranjo das tensões e as deformações induzidas se estabilizam mais cedo.

O estudo da execução de um túnel contempla basicamente três análises distintas: estabilidade da frente da escavação, estimativa das deformações induzidas no maciço e avaliação dos esforços solicitantes nos suportes. Métodos de cálculo baseados em observações empíricas ou semi-empíricas e métodos analíticos são frequentemente empregados em análises de túneis e alguns destes métodos serão detalhados a seguir.

\subsection{ANÁLISES DE ESTABILIDADE DA FRENTE}

A análise da estabilidade da frente de escavação consiste em verificar a integridade do maciço após a alteração do estado de tensões ocasionado pela escavação, até que uma estrutura de suporte seja instalada. No caso de túneis executados por tuneladora com controle da pressão de frente, a análise de estabilidade fornecerá a 
pressão de suporte mínima a ser aplicada na frente da escavação para conter as pressões do terreno e da água subterrânea. Quando a escavação ocorre em maciços autoportantes, esta pressão de frente pode até ser a atmosférica (pressão interna nula). Já em maciços pouco competentes, a aplicação de pressão de frente é fundamental para garantir a estabilidade da escavação.

Pode-se dizer que este tipo de abordagem corresponde à avaliação do estado limite último da escavação - leva-se em consideração somente a estabilidade do túnel. Uma outra abordagem é possível, em que a pressão de frente aplicada tem o objetivo de reduzir as deformações do maciço ocasionadas pela escavação. Pode-se denominar esta abordagem como estado limite de serviço da escavação. Neste item, serão apresentados métodos de cálculo para verificação do estado limite último da escavação. O estado limite de serviço será abordado mais adiante.

De uma maneira geral, pode-se dividir os métodos de cálculo de estabilidade em dois grupos: métodos analíticos, baseados nos métodos de equilíbrio limite e análise limite; e métodos numéricos, com análises em modelos bi ou tridimensionais. Considerando a notável complexidade da interação entre a escavação e o maciço, somente uma análise numérica tridimensional possibilita simular todas as etapas da escavação e pode fornecer um resultado completo e confiável dos efeitos da escavação e das pressões de estabilização consequentemente necessárias. Contudo, mesmo que métodos numéricos com a utilização dos elementos finitos sejam uma ferramenta bastante precisa para estudos dessa natureza, a complexidade e o tempo significativo gasto com computação numérica fazem com que os métodos analíticos sejam um importante recurso para otimizar os resultados em tempo, custo e precisão suficientes.

\subsubsection{Métodos analíticos}

Os métodos analíticos de verificação de estabilidade são baseados em conceitos clássicos da mecânica dos solos e da teoria da plasticidade e podem ser divididos em dois grupos: métodos de análise limite e métodos de equilíbrio limite. A análise limite tem como principal objetivo a determinação da carga que leva uma determinada estrutura ao colapso. São estimadas duas soluções (inferior e superior) que delimitam o verdadeiro valor da carga de colapso. 
$\mathrm{Na}$ formulação pelo limite inferior determina-se que a estrutura é estável se for possível atribuir a esta uma distribuição de tensões que equilibre as solicitações de forças exteriores sem que seja excedida a resistência do material em nenhum ponto. Esta formulação contempla a consideração das condições de equilíbrio e das propriedades do material, mas não leva em conta a compatibilidade de deformações. O carregamento aplicado corresponderia ao limite inferior da carga de colapso da estrutura.

$\mathrm{Na}$ formulação pelo limite superior determina-se que a estrutura sofre colapso se for possível atribuir a ela um campo de deslocamentos compatível para o qual o trabalho realizado pelas forças exteriores iguala o trabalho dissipado internamente pelas tensões na estrutura. Contempla, desta maneira, a consideração das condições de compatibilidade e das propriedades do material, mas não considera explicitamente as condições de equilíbrio. O carregamento aplicado seria igual ou maior do que a carga limite verdadeira.

O teorema do limite inferior é também denominado teorema estático, pois trata de estados de tensão estaticamente admissíveis, enquanto que o teorema do limite superior é conhecido como teorema cinemático, já que trata dos mecanismos de colapso cinematicamente admissíveis. O primeiro teorema fornece soluções a favor da segurança, enquanto que o segundo pode oferecer soluções inseguras. Em resumo, se a pressão de suporte aplicada é mais alta do que a pressão calculada pelo teorema do limite inferior, a frente estará estável. Por outro lado, a frente estará instável se a pressão aplicada for inferior à pressão calculada pelo teorema do limite superior. A frente pode estar estável se uma pressão entre os limites inferior e superior é aplicada. Por isso, em soluções pelo limite inferior pode ser adotado um fator de segurança próximo à unidade, enquanto que soluções pelo limite superior demandam a adoção de um fator de segurança superior.

Já as soluções por equilíbrio limite estão baseadas na determinação de uma superfície crítica de ruptura, considerações a respeito da distribuição das tensões na superfície de ruptura e solução do problema por meio de equações de equilíbrio das forças atuantes e das forças resistentes do solo, que é considerado como um corpo rígido. Esta metodologia combina aspectos que derivam dos dois teoremas da análise limite. As superfícies potenciais de deslizamento correspondem a determinados mecanismos de colapso, como é admitido no teorema do limite 
superior. Contudo, nem sempre são respeitados os requisitos da compatibilidade de deformações. Por outro lado, embora as condições globais de equilíbrio tenham de ser satisfeitas, as condições locais nem sempre são verificadas.

Nas avaliações da estabilidade de frente de um túnel, as análises consistem em determinar a mínima pressão interna de suporte, adotando um determinado fator de segurança, para garantir a estabilidade da escavação. Embora não tenham a consistência teórica dos métodos de análise limite, a simplicidade dos métodos de equilíbrio limite, bem como sua adaptabilidade a situações distintas constituem o seu principal atrativo.

Um dos primeiros estudos a respeito da estabilidade de frente em túneis foi realizado por Broms e Bennemark (1967), aplicável a solos coesivos em condições não drenadas. Os autores definiram um número de estabilidade $N$, definido pela Equação (3.1) que, de acordo com avaliações de casos reais, deve ser inferior a 6 para garantir condições de segurança.

$N=\frac{\sigma_{V}-\sigma_{T}}{c_{u}}$

Onde:

$\sigma_{V}$ é a tensão total vertical na profundidade do eixo do túnel;

$\sigma_{T}$ é a pressão de suporte aplicada na frente;

$c_{u}$ é a resistência não drenada do solo.

Posteriormente alguns autores questionaram o valor máximo de $N$ menor ou igual a 6 para garantir estabilidade. Peck (1969), com base em relatos de ocorrências em túneis, afirma que $N$ não pode ser superior a 4, uma vez que com valores entre 4 e 5 já são observadas instabilidades locais e a estabilidade para $N$ entre 5 e 6 é garantida somente com aplicação de ar-comprimido. Davis et al. (1980) obtiveram para túneis rasos valores de $N$ próximos a 2. ITA/AITES (2007), a partir de dados de obras e avanços experimentais e teóricos, estabelece que:

- para $N \leq 3$, a estabilidade global da frente é geralmente garantida;

- para $3<N \leq 6$ considerações especiais devem ser avaliadas e perdas de solo relativamente altas são esperadas quando $N>5$;

- para $N>6$, a frente é instável. 
Atkinson e Potts (1977) definiram a mínima pressão de suporte da frente de uma escavação circular em condições drenadas considerando duas condições limites: 1) peso específico do solo igual a zero e sobrecarga maior do que zero; 2) peso específico do solo maior do que zero e sobrecarga igual a zero. São obtidas soluções de limite inferior considerando critério de plastificação de Mohr-Coulomb para o solo, sendo apresentada na Equação (3.2) a solução para a segunda condição, que independe da sobrecarga. Destaca-se que a solução obtida independe da profundidade do túnel, sendo função somente de parâmetros de resistência do solo e geometria da escavação.

$s_{\text {min }}=\frac{2 k_{p}}{k_{p}^{2}-1} \cdot \gamma \cdot R$

Sendo:

$s_{\text {mín }}$ a mínima pressão interna de suporte da frente;

$k_{p}=\frac{1+\operatorname{sen} \phi}{1-\operatorname{sen} \phi}$ o empuxo passivo do solo, sendo $\phi$ o ângulo de atrito do solo;

$\gamma$ o peso específico do solo;

$R$ o raio da escavação.

Davis et al. (1980) apresentam uma série de soluções utilizando análise limite para túneis circulares escavados em solos coesivos não drenados, utilizando como critério de resistência a superfície de escoamento de Tresca. Os autores incorporam o conceito de profundidade relativa do túnel $(C / D$ - razão entre cobertura e diâmetro da escavação) na análise e simulam a instalação de um suporte rígido a uma distância $P$ da frente de escavação, como representado na Figura 3.4.

Figura 3.4 - Geometria do estudo de estabilidade.

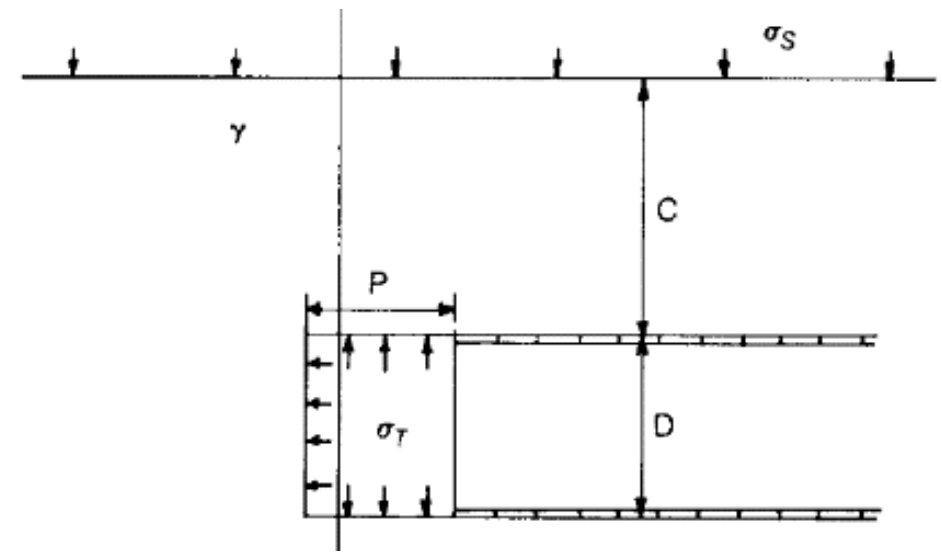

Fonte: adaptado de Davis et al (1980). 
Para a solução do problema, os autores propõem uma derivação por análise adimensional, como por $C / P, P / D, \sigma_{s} / C_{u}, \sigma_{t} / C_{u}, \gamma D / C_{u}$ e fornecem diversas soluções de limite inferior por linhas características ou campos de tensões e soluções de limite superior por mecanismos de ruptura formados por blocos rígidos, incorporando as soluções em diagramas. A condição que melhor representa a escavação por tuneladora com controle da pressão de frente seria a condição $P=0$, considerando que a pressão interna é aplicada somente na frente da escavação e assumindo comprimento não suportado atrás da face nulo, ou seja, o trecho do escudo da máquina é tomado como revestido. Para esta condição, os autores fornecem uma solução de limite inferior, cujo campo de tensões é ilustrado na Figura 3.5. A solução do problema, apresentada na Equação (3.3) pode ser interpretada como um desenvolvimento da proposta de número de estabilidade proposto por Broms e Bennemark (1967).

Figura 3.5 - Campo de tensões para análise de limite inferior.
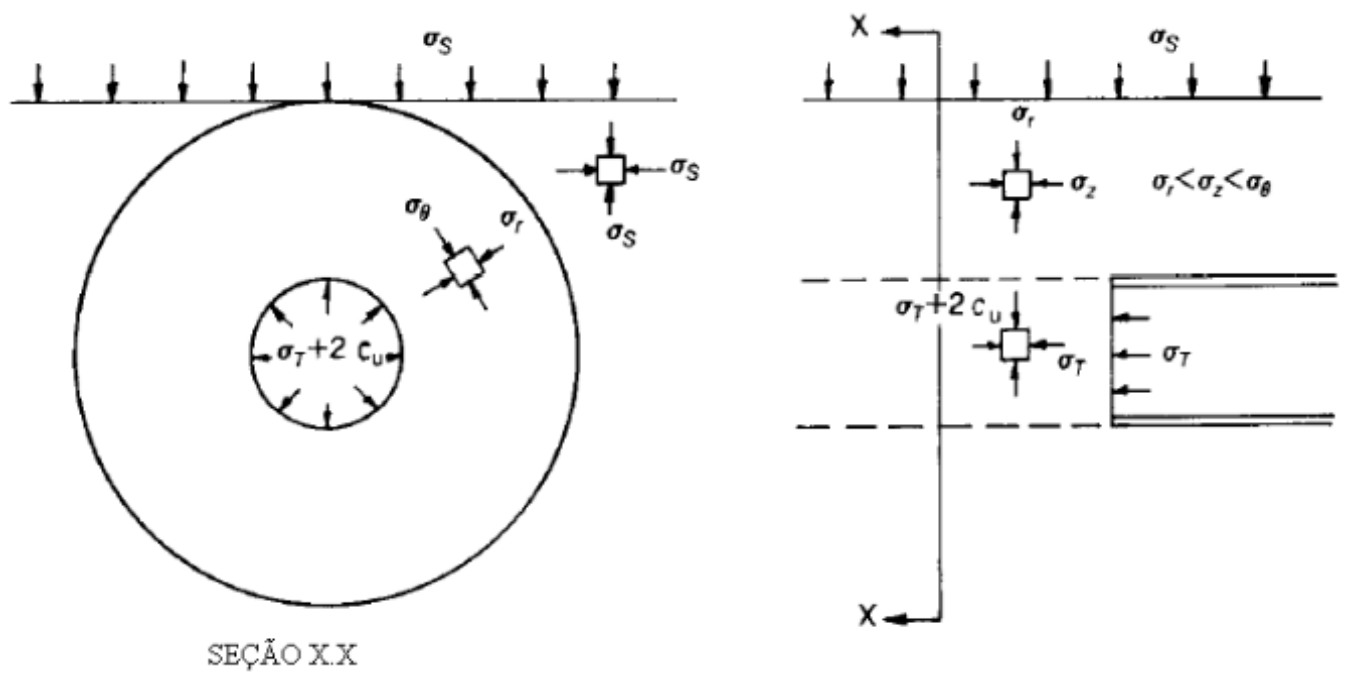

Fonte: adaptado de Davis et al. (1980).

$\frac{\sigma_{s}-\sigma_{t}}{C_{u}}=N=2+2 \ln \left(\frac{2 C}{D}+1\right)$

Sendo:

$\sigma_{s}$ a sobrecarga superficial;

$\sigma_{t}$ a pressão de frente na face do túnel;

$C_{u}$ a resistência não drenada do solo;

$C$ a cobertura de solo sobre o teto do túnel;

$D$ o diâmetro equivalente do túnel. 
Mühlhaus (1985) apresenta uma análise baseada no limite inferior com critério de escoamento de Mohr-Coulomb para determinar a máxima distância do avanço da escavação para instalação de um suporte, que simula assim condições de avanço em NATM. Heinz (1988) estende a solução para incluir o efeito de aplicação de uma pressão interna, sendo possível desta maneira simular uma escavação com tuneladora. Nas duas formulações o carregamento atuante provém da aplicação de uma sobrecarga na superfície distribuída uniformemente, ou seja, o carregamento proveniente de forças gravitacionais é nulo $(\gamma=0)$. Negro (1994) apresenta uma modificação à solução de Mühlhaus (Figura 3.6), na qual forças volumétricas axissimétricas são aplicadas radialmente em direção à cavidade para simular um campo gravitacional. O método consiste na determinação de uma pressão interna limite, conforme Equação (3.4), que, ao ser mobilizada, causa o colapso de uma abertura esférica no interior do maciço. Calcula-se, portanto, a pressão de frente a ser aplicada para equilibrar a pressão interna limite, utilizando-se a Equação (3.5).

Figura 3.6 - Solução de Mühlhaus modificada.

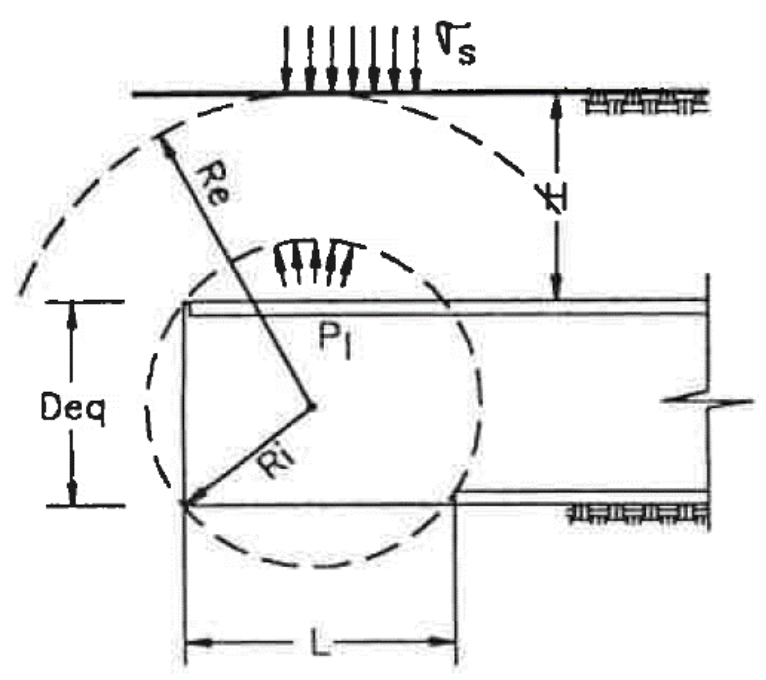

Fonte: adaptado de Negro (1994).

$p_{l}={\frac{R_{i}}{R_{e}}}^{(n-1)(\lambda-1)} \cdot\left[\sigma_{s}+\frac{\sigma_{c}}{(\lambda-1)}-\frac{\gamma R_{e}}{(n-1) \lambda-n}\right]-\frac{\sigma_{c}}{(\lambda-1)}+\frac{\gamma R_{i}}{(n-1) \lambda-n}$

Onde:

$p_{l}$ é a pressão interna limite;

$R_{i}=\frac{1}{2}\left(L^{2}+D_{e q}{ }^{2}\right)^{1 / 2}$ é o raio interno da esfera; 
$D_{e q}=\sqrt{\frac{4 A}{\pi}}$ é o diâmetro equivalente da escavação, A é a área da escavação;
$R_{e}=H+\frac{D_{e q}}{2}$ é o raio externo da esfera, sendo $\mathrm{H}$ a cobertura do túnel;
$\sigma_{c}=\frac{2 c^{\prime} \cdot \cos \phi^{\prime}}{1-\operatorname{sen} \phi^{\prime}}$ é a resistência à compressão do solo, sendo c' a coesão efetiva e $\phi^{\prime}$ o ângulo de atrito efetivo do solo;

$n=3$ corresponde ao caso tridimensional (esfera);

$\lambda=\frac{1+\operatorname{sen} \phi}{1-\operatorname{sen} \phi}$.

$p_{i}=\frac{\sigma_{o c t}-p_{l}}{F S}-\left(\sigma_{o c t}+\sigma_{s}\right)$

Onde:

$p_{i}$ é a pressão interna de suporte aplicada na frente de escavação;

$\sigma_{o c t}$ é a tensão octaédrica atuante no eixo da escavação;

FS é o fator de segurança aplicado.

Leca e Dormieux (1990) investigam a estabilidade da frente de escavação em areias utilizando um modelo em três dimensões considerando como critério de resistência a superfície de Mohr-Coulomb e assumindo condições drenadas. Os autores também fazem análises adimensionais e obtêm soluções de limite inferior e superior, que permitem estimar uma faixa de valores para pressão interna de suporte da frente de escavação.

As soluções de limite superior levam em conta três mecanismos de falha, que envolvem o movimento de troncos de cone rígidos, conforme apresentado na Figura 3.7. Os dois primeiros mecanismos se referem a mecanismos de colapso, enquanto o terceiro mecanismo representa o blow-out, ou seja, a pressão interna aplicada é tão alta que causa o soerguimento do solo na frente da escavação.

Figura 3.7 - Mecanismos de ruptura do limite superior de Leca e Dormieux (1990).
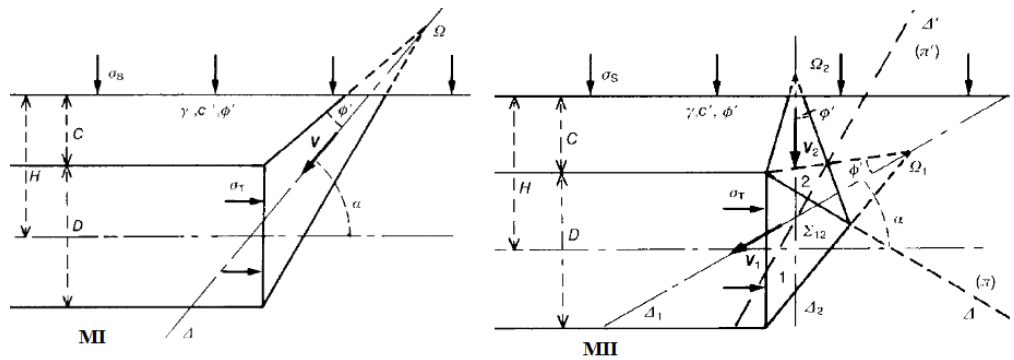

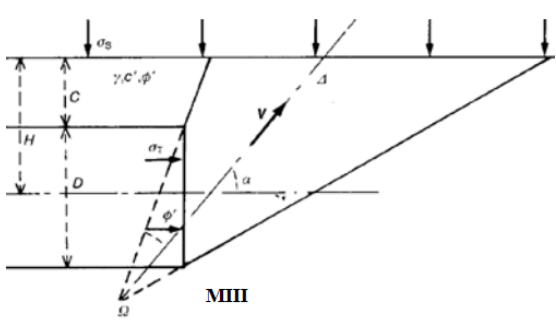

Fonte: adaptado de Leca e Dormieux (1990). 
Os autores fazem uma comparação entre resultados obtidos em laboratório por ensaios de centrífuga com os valores calculados da pressão interna $\left(P_{\text {int }}\right)$ de colapso pela análise limite inferior e superior para a condição simulada em laboratório, apresentados na Tabela 3-1.

Tabela 3-1 - Comparação das pressões internas $\left(P_{\text {int }}\right)$ de colapso previstas em

\begin{tabular}{|c|c|c|c|c|}
\hline \multirow[t]{2}{*}{$C / D$} & \multirow{2}{*}{$\begin{array}{c}\gamma \\
\left(k N / m^{3}\right)\end{array}$} & \multicolumn{2}{|c|}{$\begin{array}{l}\text { Pint }_{\text {í }} \text { colapso por } \\
\text { análise limite }(\mathrm{kPa})\end{array}$} & \multirow{2}{*}{$\begin{array}{c}P_{\text {int }} \text { de colapso em } \\
\text { laboratório }(\mathrm{kPa}) \\
\sigma \mathrm{t,f}\end{array}$} \\
\hline & & $\sigma_{\mathrm{t}, \mathrm{inf}}$ & $\sigma_{t, \text { sup }}$ & \\
\hline 1,0 & 15,3 & 29 & 2 & 6 \\
\hline 1,0 & 16,1 & 29 & 3 & 3 \\
\hline 2,0 & 15,3 & 46 & 2 & 4 \\
\hline 2,0 & 16,1 & 44 & 3 & 4 \\
\hline
\end{tabular}

Fonte: adaptado de Leca e Dormieux (1990).

A comparação mostra grande amplitude entre as pressões internas calculadas pelos limites inferior e superior. Observa-se também que as tensões internas medidas no colapso em laboratório situaram-se mais próximas às tensões calculadas pelo teorema do limite superior. Contudo, os cálculos pelo limite superior resultam em pressões internas de colapso inferiores às pressões de colapso medidas em laboratório, o que estaria contra a segurança, já que neste caso a pressão interna calculada é inferior à pressão necessária para estabilizar a frente, tomando o resultado do ensaio de laboratório como referência. As pressões internas calculadas pelo limite inferior, por sua vez, são em geral uma casa decimal superiores às tensões medidas no colapso, mostrando resultados excessivamente conservadores. Este exemplo embasa a decisão usual de se utilizar fator de segurança próximo à unidade em análises pelo limite inferior.

Mollon et al. (2009) reavaliaram o método proposto por Leca e Dormieux (1990), propondo um melhoramento do mecanismo de ruptura ao utilizar cinco cones rígidos truncados, conforme ilustrado na Figura 3.8, para representar de forma mais adequada a linha de ruptura da frente de escavação. A pressão última $\sigma_{u}$ para colapso é calculada pela Equação (3.6). Os autores compararam a eficiência do mecanismo de cinco blocos proposto com uma simulação tridimensional em elementos finitos e verificaram boa concordância entre os resultados obtidos para o valor de $\sigma_{u}$ e o formato da linha de ruptura. 
Figura 3.8 - Mecanismo de colapso proposto por Mollon et al. (2009).

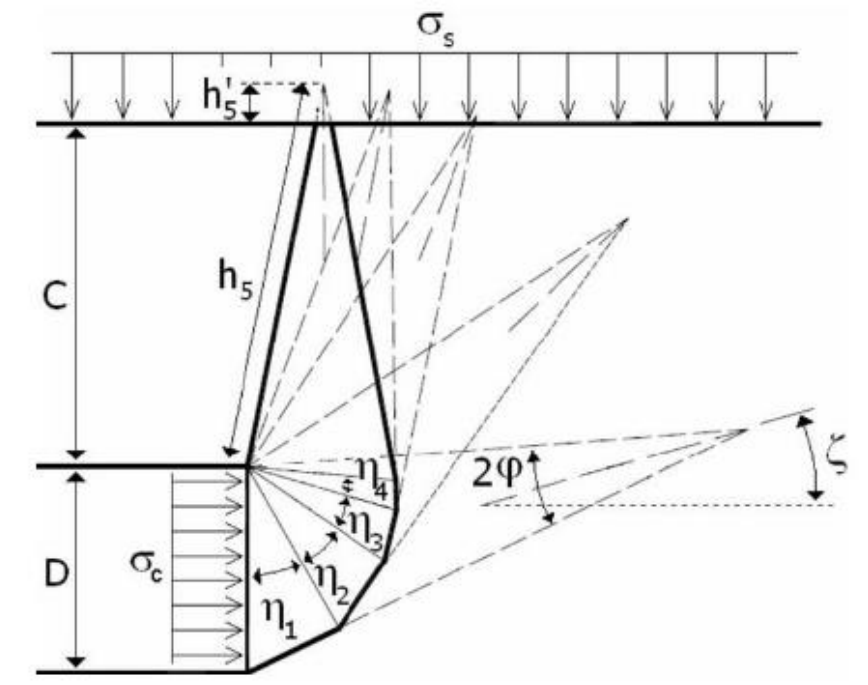

Fonte: Mollon et al. (2009).

$\sigma_{u}=\gamma D N_{\gamma}+c N_{c}+\sigma_{s} N_{s}$

Onde $\mathrm{N}_{\gamma}, \mathrm{N}_{\mathrm{c}}$ e $\mathrm{N}_{\mathrm{s}}$ são coeficientes adimensionais representando o efeito do peso do solo, da coesão e da sobrecarga, respectivamente. $O$ autor disponibiliza em seu site um programa executável para aplicação deste método - Tunnel Face Stability Software (TFSS), disponível em http://guilhem.mollon.free.fr.

No que tange às soluções por equilíbrio limite, Horn (1961, apud Kolymbas, 2005) propôs um mecanismo de ruptura tridimensional, consistindo em uma cunha a partir da frente da escavação com altura equivalente ao diâmetro da escavação, sobreposta por um bloco prismático na parte superior até atingir a superfície do terreno, com superfícies planas de ruptura, conforme apresentado na Figura 3.9. Avalia-se o equilíbrio da cunha $A B C D I J$, que pode deslizar em direção ao túnel devido ao carregamento do bloco de solo ABEFGHIJ.

O método de Horn foi o ponto de partida para o desenvolvimento de diversos outros métodos de equilíbrio limite. Anagnostou e Kovári (1994 e 1996) combinaram o mecanismo proposto com a teoria do silo para desenvolver seu método de cálculo de pressão de frente, que é amplamente utilizado. Os autores introduziram um carregamento vertical, originário no bloco rígido superior, atuando na cunha deslizante inferior. De acordo com a teoria do silo, este carregamento vertical é reduzido pelas tensões cisalhantes que atuam nas superfícies deslizantes nas laterais do bloco. A análise é realizada em condições drenadas utilizando critério de 
ruptura de Mohr-Coulomb com os cálculos sendo realizados em termos de tensões efetivas.

Figura 3.9 - Mecanismo proposto por Horn (1961, apud Kolymbas, 2005).

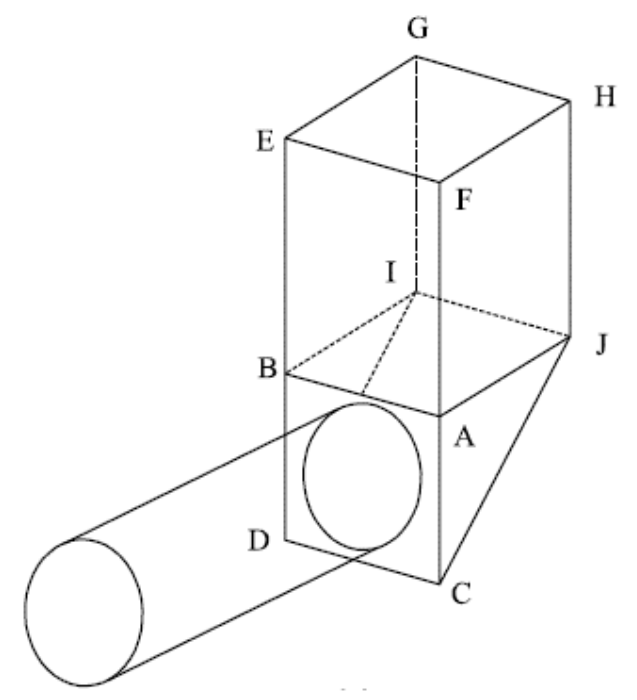

Fonte: Kolymbas (2005).

As forças solicitantes e as forças resistentes da cunha deslizante são ilustradas na Figura 3.10. O ângulo de abertura crítico da cunha é determinado iterativamente para que a força de suporte $E$ necessária seja a máxima. Determina-se a resultante da pressão de frente necessária por meio da Equação (3.7). DAUB (2016) apresenta orientações para a determinação de cada componente da equação, os quais são detalhados adiante.

Figura 3.10 - Modelo das forças solicitantes e resistentes.

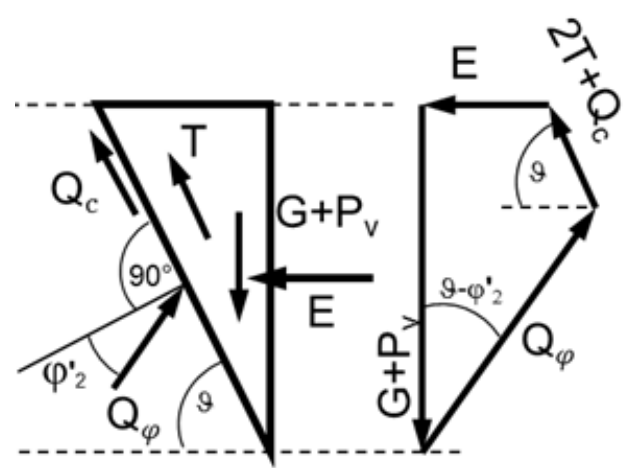

Fonte: DAUB (2016).

As forças representadas na Figura 3.10 se referem a:

$P_{v}$ : carregamento vertical pelo prisma de solo, obtido pela teoria do silo;

$G$ : peso próprio da cunha deslizante; 
$T$ : força de cisalhamento vertical na superfície de deslizamento;

$Q_{c}$ : componente da coesão da força de cisalhamento na superfície inclinada;

$Q_{\varphi}$ : componente do atrito da força de cisalhamento na superfície inclinada;

$E$ : resultante da pressão de frente aplicada pela máquina;

$\vartheta$ : ângulo crítico de abertura da cunha.

$E=\frac{\left(G+P_{v}\right) \cdot\left(\operatorname{sen}(\vartheta)-\cos (\vartheta) \cdot \tan \left(\varphi^{\prime}\right)\right)-2 \cdot T-c^{\prime} \cdot \frac{D^{2}}{\operatorname{sen}(\vartheta)}}{\operatorname{sen}(\vartheta) \cdot \tan \left(\varphi^{\prime}\right)-\cos (\vartheta)}$

Onde $c^{\prime}$ é a coesão efetiva do solo, $\varphi^{\prime}$ o ângulo de atrito e $D$ o diâmetro da escavação.

A componente do carregamento vertical do prisma de solo $\left(P_{v}\right)$ é definida como a área do prisma no topo da cunha $(A)$ multiplicada pela tensão efetiva vertical agindo no topo da cunha, ou seja, a tensão vertical na coroa do túnel $\left(\sigma_{v}\right)$, de acordo com a Equação (3.8).

$P_{v}=A \cdot \sigma_{v}=D \cdot \frac{D}{\tan (\vartheta)} \cdot \sigma_{v}$

A tensão vertical efetiva pode ser definida de duas maneiras. Em túneis rasos, com cobertura inferior a dois diâmetros equivalentes de escavação, considera-se o peso total do solo somado à sobrecarga superficial $\sigma_{s}$ - Equação (3.9). Se o túnel for profundo, é possível reduzir o carregamento vertical - Equação (3.10), considerando o arqueamento das tensões sobre a cunha de acordo com a teoria do silo de Janssen (1895, apud DAUB, 2016) - Equação (3.11).

$\sigma_{v, 1}=\gamma_{1} \cdot C+\sigma_{s}$

Onde $\gamma_{1}$ é o peso específico médio do solo na cobertura $C$ do túnel.

$\sigma_{v, 2}=\gamma_{1} \cdot h_{0}$

$\sigma_{v, 2}=\frac{\frac{A}{U} \cdot \gamma_{1}-c^{\prime}}{K \cdot \tan \left(\varphi^{\prime}\right)} \cdot\left(1-e^{-\frac{U}{A} \cdot K \cdot C \cdot \tan \left(\varphi^{\prime}\right)}\right)+\sigma_{S} \cdot e^{-\frac{U}{A} \cdot K \cdot C \cdot \tan \left(\varphi^{\prime}\right)}$

Onde $U$ representa o perímetro do prisma e $K$ o coeficiente do empuxo lateral.

A componente do peso próprio da cunha $(G)$ é definida por: 


$$
G=\frac{1}{2} \cdot \frac{D^{3}}{\tan (\vartheta)} \cdot \gamma_{2}
$$

Sendo $\gamma_{2}$ o peso específico médio do solo na cunha.

A resistência ao cisalhamento nos planos verticais da cunha é composta por duas componentes - Equação (3.14) - componente da coesão, Equação (3.14) e componente do atrito Equação (3.15).

$$
\begin{aligned}
& T=T_{C}+T_{R} \\
& T_{C}=\frac{c^{\prime} \cdot D^{2}}{2 \cdot \tan (\vartheta)} \\
& T_{R}=\tan (\vartheta) \cdot K \cdot\left(\frac{D^{2} \cdot \sigma_{v}}{2 \cdot \tan (\vartheta)}+\frac{D^{2} \cdot \gamma_{2}}{6 \cdot \tan (\vartheta)}\right)
\end{aligned}
$$

Para se obter a pressão de frente a ser aplicada no eixo da escavação, divide-se a força $E$ calculada pela Equação (3.7) pela área da escavação. A pressão de frente calculada deve ser igual ou superior à pressão hidrostática no eixo da escavação, pois, caso contrário, forças de percolação passam a atuar na frente de escavação, o que demandaria um acréscimo na resultante da pressão de frente para se obter 0 equilíbrio.

Dependo do tipo de solo escavado, o solo pode apresentar comportamento drenado ou não-drenado durante a escavação. Anagnostou e Kovári (1994) afirmam que comportamento não-drenado pode ser esperado para avanços da ordem de 0,1 a $1,0 \mathrm{~m} / \mathrm{h}(1,7$ a $16,7 \mathrm{~mm} / \mathrm{min})$ em solos com permeabilidade abaixo de $1 \times 10^{-6} \mathrm{~m} / \mathrm{s}$. Conforme mencionado anteriormente, a formulação da Equação (3.7) é indicada para condições drenadas. Portanto, quando são esperadas condições não-drenadas na escavação, deve-se utilizar algum outro método de cálculo.

Por fim, Anagnostou e Kovári (1996) desenvolveram nomogramas (Figura 3.11) relacionando coeficientes adimensionais $\left(\mathrm{F}_{0}\right.$ a $\left.\mathrm{F}_{3}\right)$ com características geométricas da escavação, o ângulo de atrito do solo e a relação entre o peso específico seco $\left(\gamma_{d}\right)$ com o peso específico submerso $\left(\gamma^{\prime}\right)$, utilizados para o cálculo da pressão de suporte efetiva $\left(s^{\prime}\right.$, em $\left.\mathrm{kPa}\right)$ da frente em máquinas EPB pela da Equação (3.16). Nos nomogramas, os autores adotaram o valor de 1,6 para relação $\gamma_{d} / \gamma^{\prime}$. 
$s^{\prime}=F_{0} \cdot \gamma^{\prime} \cdot D-F_{1} \cdot c^{\prime}+F_{2} \cdot \gamma^{\prime} \cdot \Delta h-F_{3} \cdot c^{\prime} \cdot \frac{\Delta h}{D}$

Onde:

$\gamma^{\prime}$ corresponde ao peso específico submerso do solo;

$D$ é o diâmetro da escavação;

$c^{\prime}$ corresponde à coesão efetiva do solo;

$\Delta h$ corresponde à altura da coluna d'água na base da escavação.

Figura 3.11 - Nomograma dos coeficientes adimensionais
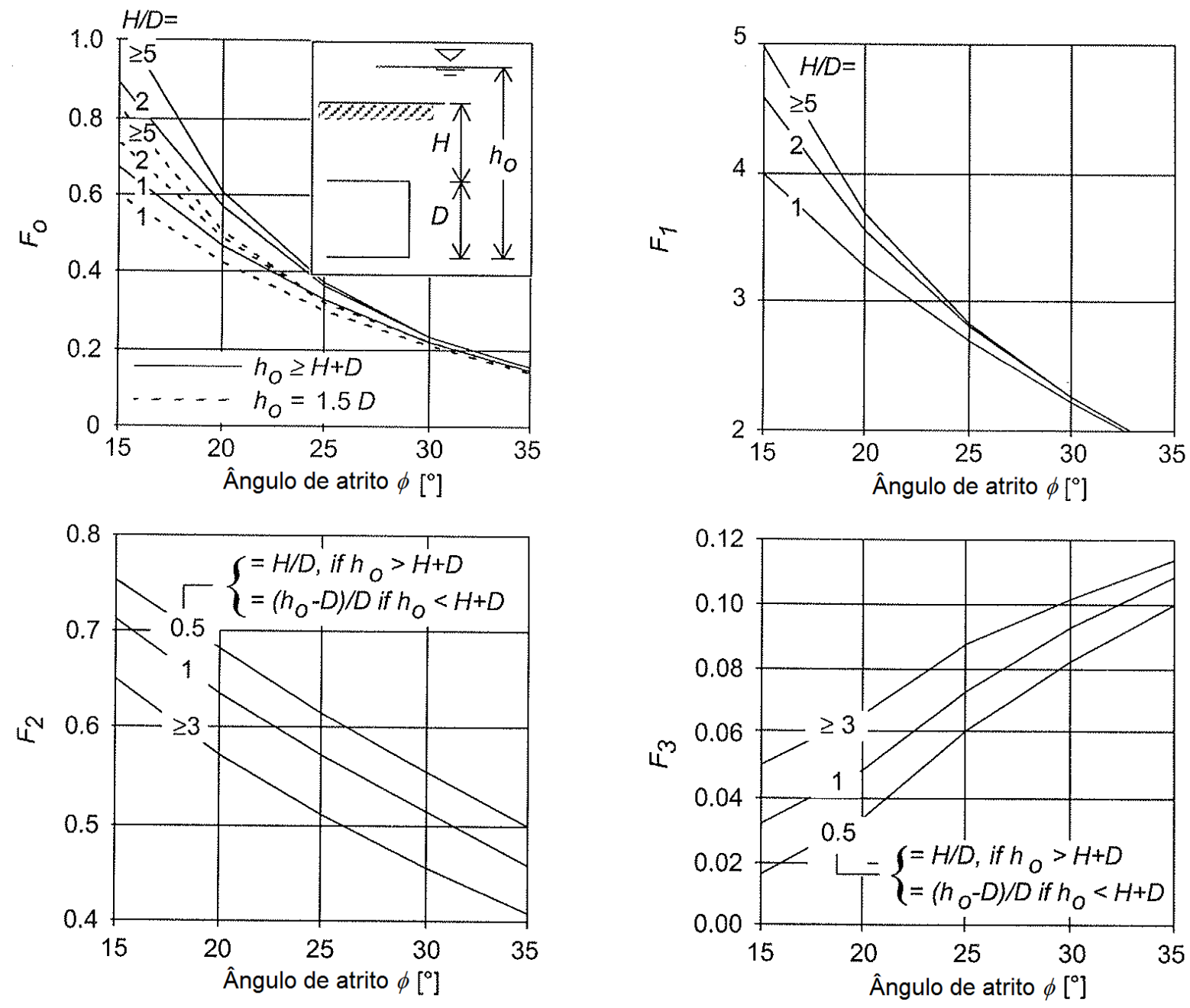

Fonte: Anagnostou e Kovári (1996).

\subsection{ESTIMATIVA DAS DEFORMAÇÕES INDUZIDAS NO MACIÇO}

Devido à alteração do estado de tensões no maciço, a escavação de um túnel inevitavelmente induz deformações que podem causar danos nas estruturas e redes de utilidades situadas na área de influência das escavações. Por isso, assim como a 
verificação da estabilidade da frente, a previsão de recalques na superfície é fundamental no projeto de túneis. No entanto, a previsão das deformações tem menor acurácia do que a verificação de estabilidade, pois o solo tem uma relação tensão-deformação não-linear, o que dificulta o conhecimento da distribuição da rigidez no solo. Este comportamento é representado somente por modelos constitutivos mais sofisticados, como será abordado adiante no item 4.6.

A principal origem dos deslocamentos do maciço é o movimento do solo para o vazio criado pela abertura do túnel. Tais deslocamentos ocorrem durante a fase de construção e dependem, de maneira geral, da dimensão e profundidade da escavação, da metodologia executiva, da velocidade e qualidade da construção e de algumas características do maciço, como sua resistência, deformabilidade e estado de tensões inicial.

No caso específico de escavação mecanizada, é possível destacar ainda alguns fatores particulares desta metodologia que contribuem para a perda de solo, conforme apresentado por Guglielmetti et al. (2008), Maidl et al. (2012) e Kolymbas (2005):

- suporte insuficiente da frente, ou seja, pressão interna suficiente para garantir estabilidade da escavação, mas insuficiente para evitar deformação do maciço na frente de escavação;

- em maciços granulares, alteração da estrutura do solo devido a vibrações ocasionadas pelo processo de escavação das tuneladoras, podendo ocasionar compactação no caso de escavação em areias fofas;

- movimento radial do solo durante a passagem do escudo devido ao alívio das tensões ao redor da escavação, antes da instalação dos anéis de revestimento. Dependendo da velocidade de deformação do solo em relação à velocidade de avanço da máquina, o perímetro escavado pode se fechar completamente sobre o escudo, que tem formato tronco-cônico;

- escavação de uma área ligeiramente maior do que a prevista para facilitar o avanço da máquina e reduzir as chances do escudo ficar preso no terreno. Além disso, ao realizar curvas de raio reduzido com a tuneladora, uma leve sobreescavação é necessária para permitir a passagem do escudo;

- volume ou pressões de grout insuficientes para preencher o espaço anelar. Segundo Mair e Taylor (1997) e Möller e Vermeer (2008) esta é a principal causa 
dos recalques em uma escavação mecanizada com controle da pressão interna. Mesmo que o volume de grout injetado exceda o volume teórico do espaço anelar, Mähr e Herle (2004) observaram que os recalques ocorridos não são revertidos, pois um ciclo de carregamento e descarregamento no solo resulta em variação final do volume, normalmente em uma compactação.

Uma origem secundária dos deslocamentos, que geralmente não ocorre em escavações mecanizadas com controle da pressão interna de frente, está associada ao adensamento causado pela redução da pressão neutra e aumento da tensão efetiva, ocasionado por rebaixamento do lençol freático durante a escavação do túnel, seja por um sistema de drenagem ou pela própria permeabilidade do revestimento provisório do túnel. Nas escavações por tuneladora o controle da pressão de frente permite a escavação abaixo do nível freático, o que faz com que o rebaixamento não seja necessário. Além disso, o revestimento instalado já é o definitivo, evitando a drenagem de água pelo revestimento.

Outra possível origem de recalques seria a deformação do revestimento após sua instalação. Ocorrências deste tipo são esperadas em túneis convencionais, em que o revestimento em concreto projetado apresenta baixo módulo de elasticidade nas primeiras idades, sendo passível de sofrer deformações com o carregamento do solo. Já em túneis escavados por TBM, os segmentos do revestimento ao ser instalado já atingiram suas resistência e módulo de elasticidade finais, sendo que essa origem dos recalques também pode ser negligenciada em escavações mecanizadas.

Devido aos inúmeros fatores envolvidos para previsão dos deslocamentos por conta da escavação de um túnel, a utilização de cálculos numéricos tende a ser a melhor metodologia para realizar as previsões. Seu uso permite simular o avanço da execução do túnel em detalhes e incluir considerações a respeito do comportamento do maciço por meio de modelos constitutivos apropriados, como será detalhado no item 4. Entretanto, assim como nas verificações de estabilidade da frente, a complexidade dos modelos numéricos torna-os muito trabalhosos, fazendo com que metodologias mais simplificadas, como métodos empíricos ou semi-empíricos sejam empregados. 


\subsubsection{Métodos empíricos para previsão de recalques superficiais}

Os métodos empíricos para estimativa de recalques são baseados em avaliações de medições de campo ou em modelos de laboratório. Uma das soluções mais empregadas atualmente é baseada na formulação proposta por Peck (1969), que sugere que a distribuição transversal dos recalques superficiais tem a forma aproximada de uma curva de Gauss, descrita pela Equação (3.17).

$\rho=\rho_{\text {máx }} \cdot e^{\left(\frac{-x^{2}}{2 i^{2}}\right)}$

Onde:

$\rho$ é o recalque a uma distância $x$ do eixo da bacia de recalques;

$\rho_{\text {máx }}$ é o recalque máximo no eixo da bacia;

$i$ é a abscissa de inflexão da curva de Gauss, onde ocorre a máxima distorção angular. É medida a partir do ponto de recalque máximo até o ponto em que $\rho=0,606 \cdot \rho_{\text {máx }}$, conforme mostrado na Figura 3.12.

Figura 3.12 - Perfil transversal dos recalques (curva de Gauss)

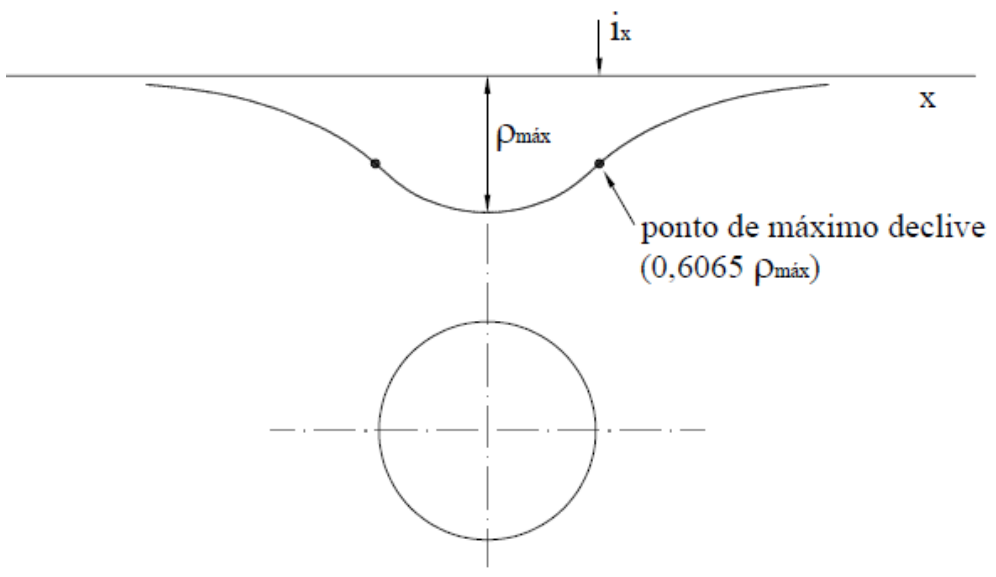

Fonte: adaptado de Marques (2006).

Para estimativa do ponto de inflexão da curva de Gauss e da largura da bacia de recalque, Peck (1969) utiliza um ábaco baseado em dados de instrumentação de alguns casos de obra, apresentado na Figura 3.13a, relacionando as grandezas adimensionais $Z / D$ (profundidade do eixo do túnel pelo diâmetro da escavação) com 2i/D (dobro da distância do ponto de inflexão da curva de Gauss do eixo da escavação pelo diâmetro da escavação). Com base em dados de instrumentação do Metrô de São Paulo, Celestino e Ferreira (1996) desenvolveram uma adequação do ábaco para os solos da cidade de São Paulo (Figura 3.13b). 
Figura 3.13 - Ábacos para determinação do ponto de inflexão da curva de Gauss. I rocha, argila dura, areia acima do NA; II - argila mole a rija; III - areia abaixo do NA.

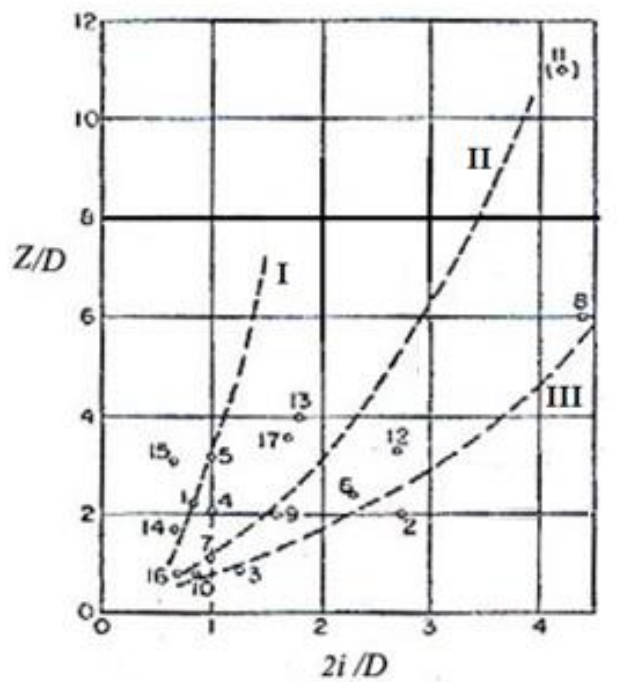

(a)

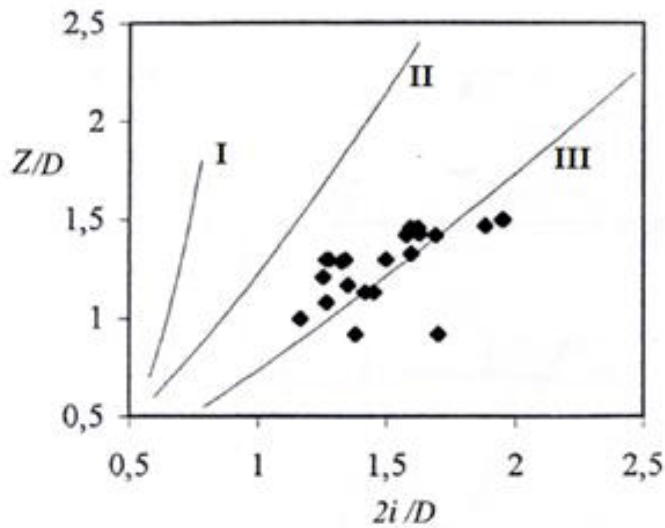

(b)

Fonte: Silva (2008)

Atkinson e Potts (1977), O'Reilley e New (1982), Mair et al. (1981), entre outros, apresentam expressões para o cálculo do ponto de inflexão da curva (i), levando em consideração o tipo de solo escavado e a geometria da escavação. De uma maneira geral, pode-se relacionar $i, D$ e $Z$ de acordo com a expressão:

$\frac{2 i}{D}=a \cdot\left(\frac{Z}{D}\right)^{b}$

Sendo $a$ e $b$ adimensionais empíricos definidos em função do tipo de solo - em geral, utiliza-se em solos argilosos $a=1,0$ e $b=0,8 a 1,0$; em solos arenosos, $a=$ 0,5 e $b=1,0$.

Analisando diversos dados de bacias de recalque, Celestino e Ruiz (1998) destacam que uma curva do tipo Yield Density, cuja formulação é apresentada na Equação (3.19), fornece um melhor ajuste aos resultados de instrumentação do que a curva gaussiana.

$\rho=\frac{\rho_{\text {máx }}}{1+\left(\frac{|x|}{a}\right)^{b}}$

Sendo a um parâmetro em função do tipo de solo relacionado com a largura da bacia que varia conforme a profundidade do túnel e $b$ um adimensional que assume valores entre 2 e 3 para argilas porosas e 2 e 2,8 para argilas duras. 
Marshall et al. (2012) realizaram ajustes de alguns tipos de curvas de aproximação em dados de recalque reais em de um túnel escavado em areia e verificaram que o ajuste das bacias pela curva Yield Density foi mais preciso do que pela curva de Gauss em todos os casos. Os autores atribuem a dispersão nos valores publicados do ponto de inflexão da bacia de recalque ao ajuste por vezes não muito preciso da curva de Gauss à bacia real. Analisando bacias de recalque provocadas pela escavação com máquina tuneladora EPB na Linha 5 do Metrô de São Paulo, Silva et al. (2016) também observaram melhor ajuste da curva Yield Density do que a curva de Gauss.

Para estimar o volume da bacia de recalque superficial por unidade de comprimento de túnel $\left(V_{S}\right)$, integra-se a curva de Gauss e a curva Yield Density, conforme apresentado, respectivamente, nas expressões a seguir:

$$
\begin{aligned}
& V_{S}=\sqrt{2 \pi} \cdot \rho_{\text {máx }} \cdot i \\
& V_{s}=\frac{2 \pi \cdot a \cdot \rho_{\text {máx }}}{b \cdot\left|\operatorname{sen}\left(\frac{\pi}{b}\right)\right|}
\end{aligned}
$$

Denomina-se volume de perda de solo por unidade de comprimento do túnel, $V_{p}(\%)$, a relação entre a área da bacia de recalques e a área da escavação - Equação (3.22).

$V_{p}=\frac{V_{s}}{A}$

Estimando-se a perda de solo e a largura da bacia de recalques pelo tipo de solo e método construtivo, pode-se calcular o recalque superficial máximo esperado utilizando as Equações (3.20) e (3.21).

Segundo Mair e Taylor (1997) e Maidl et al. (2012), em escavações mecanizadas com controle de pressão de frente a perda de solo em solos granulares pode ser estimada em torno de $0,5 \%$, enquanto que em argilas moles espera-se entre $1 \% \mathrm{e}$ $2 \%$ de perda de solo. Com os constantes avanços da tecnologia da escavação mecanizada espera-se que os volumes de perda de solo medidos sejam ainda menores com o passar do tempo. Bilfinger et al. (2013) registram perda de solo média inferior a $0,3 \%$ na escavação com máquina tuneladora na Linha 4 do Metrô de São Paulo em solos da Bacia Sedimentar de São Paulo. Na escavação da Linha 5, 
Silva et al. (2016) registraram valores sempre inferiores a $1 \%$ na escavação mecanizada neste tipo de solo. Contudo, os autores registram também perdas de solo superiores a $6 \%$ na escavação em zona de transição solo/rocha em maciço précambriano.

Ao se tratar de escavações pela metodologia convencional, Celestino e Ferreira (1996) compilaram dados de diversas escavações do Metrô de São Paulo em diferentes tipos de solo e verificaram valores de perda de solo em média inferiores a $1 \%$. Contudo, os autores registram um caso extremo de perda de solo de $8,7 \%$. Silva et al. (2017) registram perda de solo máxima da mesma ordem de grandeza na escavação de um túnel convencional em solo residual da Linha 5 do Metrô de São Paulo.

Dimmock e Mair (2007) apresentam uma avaliação da perda de solo de diversos casos de obras de túneis escavados na argila de Londres por máquinas tuneladoras de frente aberta e pela metodologia convencional. Os autores dividiram a análise da perda de solo pelas etapas da escavação e observaram que nas escavações mecanizadas aproximadamente $30 \%$ dos recalques ocorreram antes da passagem da máquina pela seção de instrumentação, $20 \%$ ocorreram durante a passagem da frente, $35 \%$ durante a passagem do escudo e $15 \%$ após a instalação do revestimento. Já em escavações convencionais, 50\% dos recalques ocorreram antes da chegada da frente na seção de instrumentação, 25\% durante a passagem da frente e $25 \%$ após a instalação do revestimento. Cabe destacar que a escavação mecanizada avaliada foi realizada com frente aberta, ou seja, sem a aplicação de uma pressão interna para estabilizar o maciço, que se tratava de uma argila sobreadensada muito competente. Pelos resultados observa-se que a maior parte dos recalques ocorridos na escavação mecanizada foi devido à perda de solo ocorrida durante a passagem do escudo, em decorrência da acomodação do terreno no espaço anelar. É possível verificar também a maior relaxação do maciço que ocorre em uma escavação convencional, onde grande parte da deformação ocorreu antes da instalação do revestimento do túnel.

Guglielmetti et al. (2008) analisaram as curvas longitudinais de recalques em 3 projetos que utilizaram máquinas do tipo EPB para escavação de túneis de grande diâmetro. Os autores observaram que em média $25 \%$ do recalque final medido ocorreu à frente da escavação, ou seja, antes da passagem da frente da máquina 
pela seção de instrumentação, sendo que a maior parte dos recalques ocorreu após a instalação do revestimento e injeção do grout. Estes resultados diferem do que foi observado por Dimmock e Mair (2007), principalmente devido ao tipo de máquina utilizado. Em uma escavação com máquina do tipo EPB, a pressão aplicada na frente do túnel e na injeção do grout auxilia na sustentação do maciço durante a passagem do escudo, reduzindo assim os recalques ocorridos durante a passagem do escudo pela seção de instrumentação.

\subsection{AVALIAÇÃO DOS ESFORÇOS NO SUPORTE DA ESCAVAÇÃO}

A determinação dos esforços solicitantes nos suportes da escavação é um típico problema de interação solo-estrutura, onde as propriedades geomecânicas do maciço devem ser analisadas juntamente com a capacidade resistiva do suporte, que tem a função de estabilizar as deformações no maciço e equilibrar as cargas potenciais atuantes. Entretanto, como a escavação proporciona a redistribuição de tensões no maciço, o carregamento atuante e os deslocamentos ocorridos no suporte são interdependentes, dificultando a determinação do estado de tensãodeformação do sistema.

O carregamento atuante no suporte da escavação é influenciado por alguns fatores, tais como: tensões iniciais e propriedades geotécnicas do maciço envolvente, características geométricas da escavação, processo construtivo adotado e do tipo de características do suporte adotado. Em escavações mecanizadas, que utilizam anéis de revestimento pré-moldados como suporte da escavação, há um fator adicional fundamental a ser considerado, que é a existência de juntas entre os segmentos, as quais têm grande influência na distribuição internas das forças atuantes no suporte, segundo resultados obtidos por Do (2014). De acordo com o autor, a posição e quantidade de juntas entre os segmentos tem um efeito significativo na deformação e nos esforços atuantes no segmento.

Conforme descrito no item 2.2.2, em túneis em solo escavados mecanicamente o suporte é composto por anéis segmentados de concreto pré-moldado, os quais já constituem o revestimento definitivo do túnel e por isso devem ser dimensionados tanto para os esforços construtivos quanto aos esforços definitivos. Esta é uma grande diferença entre as metodologias executivas de túneis, pois geralmente em 
túneis convencionais o revestimento é dividido em duas etapas: revestimento primário ou provisório, dimensionado para resistir ao carregamento do solo durante a etapa construtiva e o revestimento secundário ou definitivo, que é geralmente impermabilizado e deve resistir ao carregamento do solo e à pressão de água. Contudo, é possível dimensionar os revestimentos primário e secundário para trabalharem em conjunto, conforme apresentado por Chanquini (2003), o que reduz expressivamente a espessura final do revestimento.

Os esforços construtivos da escavação mecanizada são os originários na própria fabricação, na estocagem e no transporte dos segmentos, no seu manuseio e posicionamento pela máquina tuneladora e nos esforços decorrentes do avanço da máquina e injeção do grout. Dentre os esforços definitivos, destacam-se o empuxo do solo, empuxo hidrostático (caso a escavação ocorra abaixo do nível do lençol freático) e efeito de sobrecarga na superfície. Devido ao caráter definitivo do revestimento, podem ser necessárias análises para avaliação dos esforços solicitantes nos anéis ocorridos devido ao efeito do descarregamento do maciço ocasionado por escavações para a execução de subsolos em edifícios que possam ser construídos sobre o túnel.

Para estimar os esforços da etapa definitiva existem diversas metodologias de cálculo que levam em consideração a complexidade da interação solo-estrutura, podendo ser agrupadas essencialmente em métodos empíricos ou semi-empíricos, simulações numéricas e métodos analíticos, dentre os quais se destacam o método de convergência-confinamento e o método das reações hiperestáticas.

Os métodos empíricos são amplamente utilizados para definição dos suportes em túneis escavados em rocha, baseados essencialmente nas classificações geomecânicas do maciço. Para túneis escavados em solo, métodos empíricos não são adequados justamente pela natureza complexa da interação solo-estrutura. Peck (1969) propôs um método aplicável a suportes circulares flexíveis baseado em túneis escavados em solos argilosos. Trata-se de um método conservador, que define que os suportes sejam dimensionados para resistirem a uma compressão uniforme correspondente à tensão total vertical no nível do eixo do túnel. Para estimar os momentos fletores, é imposta uma distorção radial, que é função do tipo de solo escavado. 


\subsubsection{Métodos analíticos para estimativa de esforços nos suportes}

Dificilmente será encontrada uma solução analítica que satisfaça a geometria do problema, as leis de comportamento do maciço e as condições de contorno do problema. Por isso, soluções analíticas são sujeitas a hipóteses simplificadoras para permitir a obtenção de uma solução fechada. Consequentemente, pode ser difícil extrapolar com precisão os resultados obtidos para as condições de campo. Entretanto, soluções analíticas podem ser úteis para avaliar resultados de análises numéricas e para realizar estudos de sensibilidade ao alterar alguns parâmetros do projeto.

As principais hipóteses admitidas em soluções analíticas são as seguintes: seção do túnel circular, suporte constituído por um anel circular de peso desprezível e espessura constante, o solo e o suporte são admitidos como materiais homogêneos, isotrópicos e com comportamento elástico linear, o estado de tensão inicial do maciço é uniforme, definido em função da profundidade do eixo do túnel e do coeficiente de empuxo em repouso.

Muir-Wood (1975) apresenta a solução de uma abertura circular em meio elástico, assumindo que o revestimento circular se deforma em formato elíptico quando carregado, além de considerar o efeito da interação entre o revestimento e o solo circundante, por meio de tensões tangenciais. Para definir o carregamento atuante no revestimento, o autor propõe adotar apenas $50 \%$ das tensões iniciais in situ, devido ao relaxamento e redistribuição de tensões provocados pela escavação. $O$ autor também sugere a redução da rigidez do revestimento em função da quantidade de juntas, utilizando-se a Equação (3.23), onde é esperada uma redução da inércia em revestimentos que tenham a partir de 5 juntas. $O$ momento de inércia da junta do segmento $\left(I_{j}\right)$ normalmente é desprezado.

$I_{e}=I_{j}+\left(\frac{4}{n}\right)^{2} I$

Onde:

$I_{e}$ é o momento de inércia efetivo do revestimento, sendo que $I_{e} \leq I$;

I momento de inércia do revestimento contínuo;

$n$ é a quantidade de juntas do revestimento, sendo que $n>4$. 
Einstein e Schwartz (1979) propõem uma solução que leva em consideração a relação entre a rigidez do suporte, a rigidez do maciço e o estado de tensões in situ. Para considerar a interação entre o revestimento e o solo no contorno, os autores introduzem dois coeficientes adimensionais: o coeficiente de compressibilidade, que estabelece uma medida da rigidez relativa à compressão do suporte em relação ao maciço; e o coeficiente de flexibilidade, que estabelece uma medida relativa à flexão do suporte e do maciço. Para deduzir as expressões dos esforços solicitantes são consideradas duas condições limites, com ou sem deslizamento do suporte em relação ao maciço, ou seja, transmitindo ou não esforços cisalhantes entre o revestimento e o maciço.

Schwartz e Einstein (1980) complementam a solução anterior, apresentando fatores de correção para considerar o atraso da instalação do revestimento do túnel e uma plastificação do maciço. Cabe destacar que a solução foi desenvolvida para escavações pelo método NATM, ou seja, não há a consideração de aplicação de pressão de suporte interna, permitindo, portanto, um maior relaxamento e consequente deslocamento do maciço, o que resulta em uma redução no carregamento do suporte.

\subsubsection{Método de convergência e confinamento}

No método de convergência e confinamento, apresentado em Panet e Guenot (1982), a análise da resposta tridimensional do maciço ao redor da escavação é reduzida a um problema de estado plano, avaliando a resposta de uma seção transversal típica ao efeito de uma redução contínua na tensão radial atuante no perímetro da escavação a partir do valor inicial $p_{0}$ até zero. As hipóteses consideradas nas análises são as seguintes (Oreste, 2009): os túneis são considerados circulares e profundos; o estado de tensões iniciais é hidrostático e uniforme ao redor da cavidade (a variação de tensão com a profundidade do túnel não é considerada); o maciço é considerado um meio contínuo, homogêneo e isotrópico. Na Figura 3.14 é ilustrada a geometria do problema de um túnel de raio $R$, aplicando-se uma pressão interna fictícia $p$. Denomina-se $p_{0}$ a tensão natural do terreno in situ e $u$ o deslocamento radial no perímetro do túnel. 
Figura 3.14 - Geometria considerada no método de convergência e confinamento.

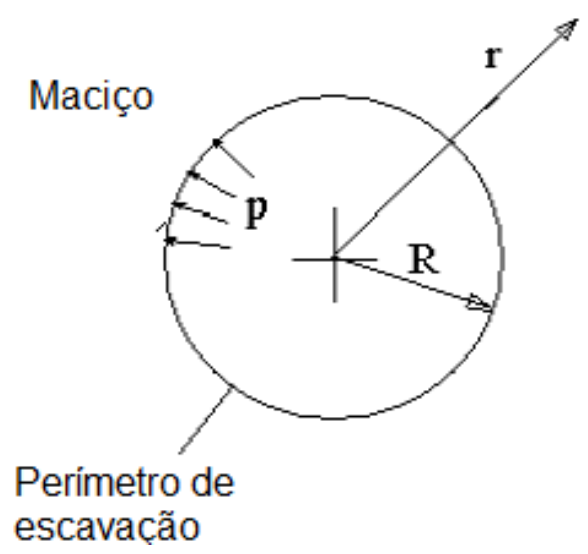

Fonte: adaptado de Oreste (2009).

O método da convergência e confinamento é baseado em duas curvas: a curva característica do maciço, que representa a relação entre a pressão radial interna e o deslocamento radial de um ponto situado no contorno da escavação; e a curva característica do suporte, que define a deformação do suporte de acordo com a pressão radial aplicada pelo terreno.

A curva característica do maciço é obtida recorrendo-se às teorias da elasticidade e da plasticidade, associadas a diferentes critérios de ruptura. $O$ trecho elástico da deformação do solo devido à escavação do túnel pode ser definido a partir de relações de tensão e deformação de acordo com a teoria da elasticidade, equilíbrio das forças e equações de deformação sob condições axissimétricas. Considerando as condições de contorno e combinando as equações, obtém-se a expressão do deslocamento radial no campo elástico em função do raio da abertura e da pressão interna, denominada curva de convergência e confinamento em um meio elástico linear, apresentada na Equação (3.24):

$u=-\frac{1+v}{E}\left(p_{0}-p\right) \cdot R$

É possível também obter a curva característica considerando o maciço com um comportamento elastoplástico. O limite elástico do maciço é atingido quando, para uma dada pressão interna com variação do raio $r$, o estado de tensões atinge a condição limite definida pelo critério de resistência. A tensão radial no raio onde ocorre a plastificação é denominada pressão crítica $\left(p_{c r}\right)$, a qual é função dos parâmetros de resistência do solo. Na Figura 3.15 é apresentada a curva característica do maciço, dividindo o trecho elástico e o trecho plástico da curva. 
Considerando o critério de resistência Mohr-Coulomb, por exemplo, $p_{c r}$ é calculada por (Oreste, 2009):

$p_{c r}=p_{0} \cdot(1-\operatorname{sen} \phi)-c \cdot \cos \phi$

Figura 3.15 - Exemplo de curva característica do maciço.

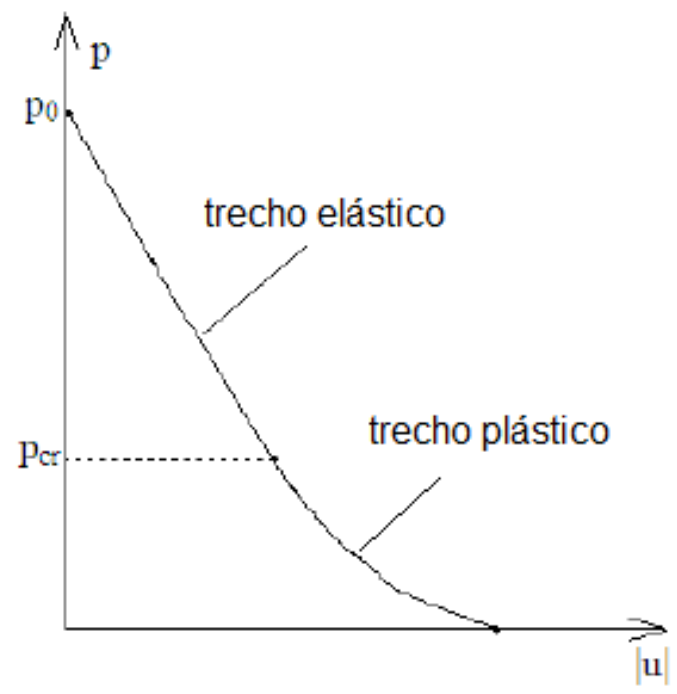

Caso a pressão crítica calculada seja negativa ou igual a zero, o limite elástico não é atingido em nenhum ponto do maciço e a curva característica do maciço é uma reta. Já pressões críticas positivas indicam a formação de uma zona com comportamento plástico, limitado por um raio de plastificação. Pode-se adotar o peso do material na região plastificada como uma carga suplementar atuante sobre o suporte.

Analisando o formato da curva característica do maciço é possível identificar diferentes tipos de resposta do maciço à escavação do túnel, conforme ilustrado na Figura 3.16. A curva 1 apresenta o comportamento de um maciço autoportante, com deformações dentro do estado elástico. O ponto $u_{1}$ indica a deformação radial final do maciço após a escavação, sem a aplicação de revestimento na abertura. $\mathrm{Na}$ curva 2 também está representado um maciço autoportante, com estabilização da deformação sem a necessidade da aplicação de um revestimento. Nesta curva, após atingir a deformação $\mathrm{u}_{2}$, a plastificação do maciço começa a ocorrer. Neste caso, a instalação de um revestimento é recomendável para limitar a deformação radial final do maciço, reduzindo a perda de solo e recalques superficiais. Já a curva 3 representa um maciço em que a instalação de um revestimento é fundamental para evitar o colapso da abertura 
Figura 3.16 - Diferentes curvas características do maciço.

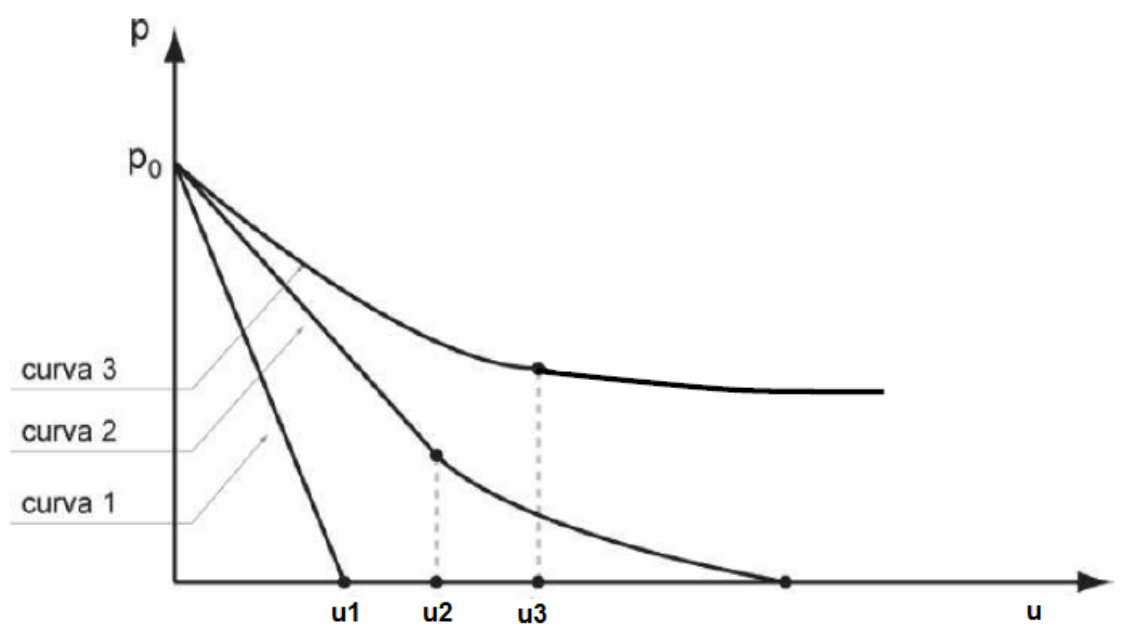

Fonte: adaptado de Cecílio (2009).

As curvas características do maciço apresentadas não levam em consideração a influência do revestimento do túnel nos deslocamentos. Foi avaliada somente a variação de uma pressão interna genérica, que provoca uma resposta no maciço em termos de deslocamento e extensão da zona plastificada. Para avaliar com maior precisão a interação entre a escavação do maciço e a estrutura de suporte, é necessário definir a linha de reação do suporte e especificar a redução da pressão interna de suporte.

A pressão interna de suporte é um recurso introduzido para permitir que um problema tridimensional seja tratado em um modelo simplificado bidimensional, conforme mostrado nas seções longitudinais da Figura 3.17, que apresenta as seguintes situações:

- quando a frente de escavação está distante da seção em análise, a pressão interna é igual a $p_{0} \mathrm{e}$ a alteração do estado de tensões na seção em estudo é negligenciável (Figura 3.17.a);

- com a aproximação da frente de escavação à seção em análise ocorre alívio de tensões à frente da escavação, ocasionando a redução da pressão interna e o aparecimento de deslocamentos radiais antes mesmo da passagem da escavação pela seção (Figura 3.17.b);

- à medida que a frente de escavação passa e se afasta da seção em análise, a influência da escavação é representada pela redução da pressão interna, até que seu valor seja nulo, em função do afastamento da frente de escavação (Figura 3.17.c-e). 
Figura 3.17 - Avanço da frente de escavação em relação à seção em análise.

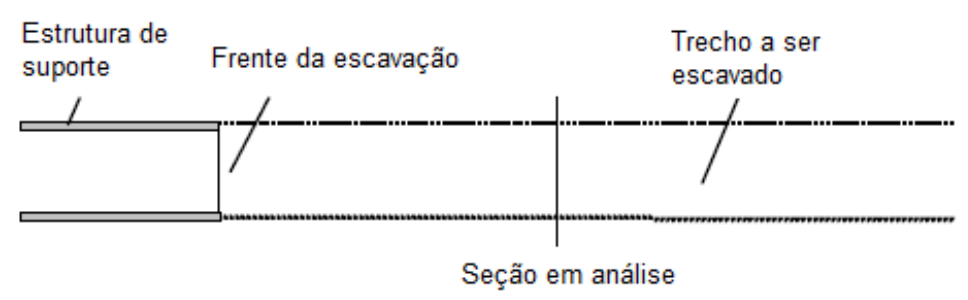

(a)

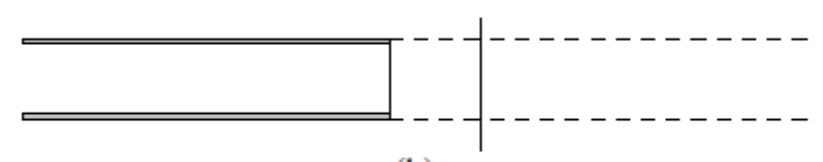

(b)

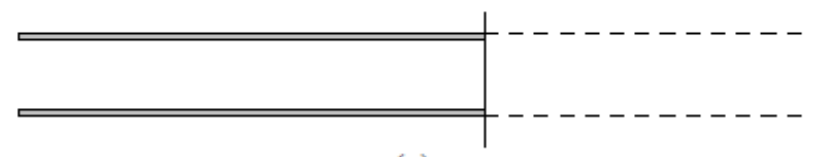

(c)

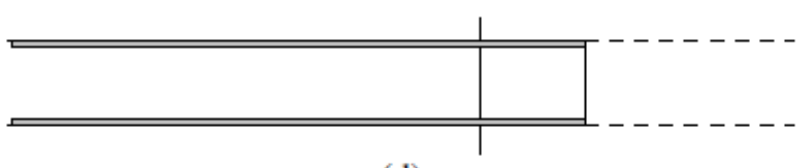

(d)

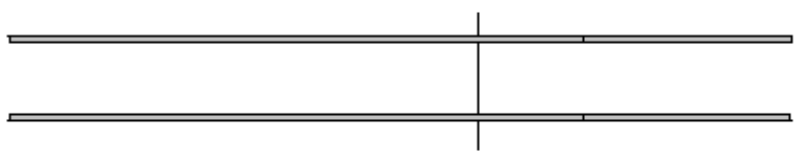

(e)

Fonte: adaptado de Oreste (2009).

Com este conceito de pressão interna, pode-se dizer que o método de convergência e confinamento é uma representação gráfica das deformações que ocorrem ao longo do eixo do túnel, com cada ponto da curva representando uma seção particular com relação à posição da frente de escavação.

A influência do suporte da escavação é representada por meio das linhas de reação do suporte, que geralmente é admitido como tendo um comportamento linear que varia em função da rigidez $k$ do tipo de suporte utilizado. Oreste (2003) apresenta formulações para diversas linhas de reação típicas para diferentes tipos de suporte, como perfis metálicos, concreto projetado e tirante de resina, além da combinação de diferentes materiais. Na combinação de diferentes tipos de suporte admite-se que a rigidez do conjunto é a soma da rigidez de cada componente. Uma curva típica de interação do suporte com o maciço é ilustrada na Figura 3.18. 
Figura 3.18 - Curva característica do maciço e linha de reação do suporte.

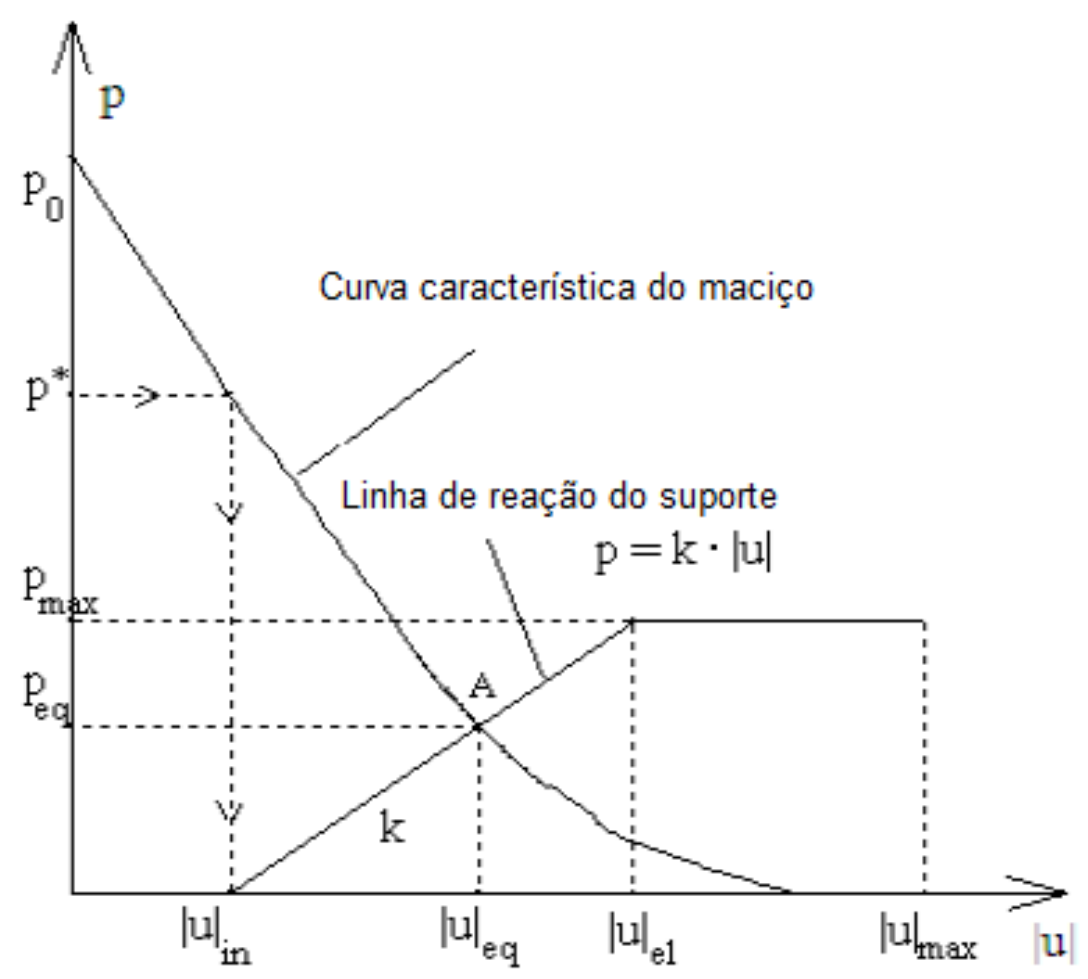

Onde:

$p^{*}$ e $u_{\text {in }}$ representam a pressão interna e o deslocamento radial no momento em que o suporte é instalado;

$p_{\max }$ é a máxima pressão resistente do suporte;

$p_{e q}$ e $u_{e q}$ são o carregamento no suporte e o deslocamento radial da parede na condição final de equilíbrio;

$u_{e l}$ é o deslocamento radial quando o suporte atinge o limite elástico;

$u_{\text {max }}$ é o deslocamento radial que provoca ruptura do suporte;

$k$ representa a rigidez do suporte.

No gráfico da Figura 3.18 é possível observar alguns pontos importantes a respeito do método de convergência e confinamento: o suporte é instalado após a ocorrência de deslocamentos radiais $\left(u_{i n}\right)$, por isso, o carregamento $p^{*}$ atuante inicialmente no suporte é inferior a $p_{0}$; como os suportes não são infinitamente rígidos, após sua instalação ainda é possível a ocorrência de deslocamentos no maciço, causados pela deformação do suporte, até que o equilíbrio de interação solo-estrutura seja atingido; quanto mais cedo o suporte for instalado e quanto maior sua rigidez, maiores serão os esforços solicitantes atuantes no revestimento e menores serão os deslocamentos finais. 
Observando o gráfico apresentado na Figura 3.19, é possível distinguir também uma diferença fundamental entre as metodologias de escavação, conforme destacado por Möller e Vermeer (2008). Em um túnel convencional é permitida uma maior deformação do solo antes da instalação do revestimento (linha de reação I, pressão atuante $p_{2}$ ), afinal este é um dos princípios do método - o próprio maciço circundante é um elemento responsável por resistir a parte do carregamento proveniente da escavação (quando o solo tem competência para tal). Já em túneis mecanizados com controle da pressão interna em geral ocorre pouca deformação do maciço antes da instalação do revestimento (linha II), aumentando assim os carregamentos que deverão ser resistidos pelo revestimento de suporte (pressão atuante $p_{1}$ ), resultando também em menores magnitudes de recalque. Cabe ainda destacar que esta análise avalia a pressão no revestimento imposta pelo carregamento do maciço, sem considerar a parcela proveniente do empuxo da água, para a qual os revestimentos de túneis mecanizados já devem estar dimensionados, enquanto que o revestimento primário de túneis convencionais é instalado em condições drenadas.

Figura 3.19 - Diferença da pressão atuante no suporte em túnel convencional e em túnel mecanizado.

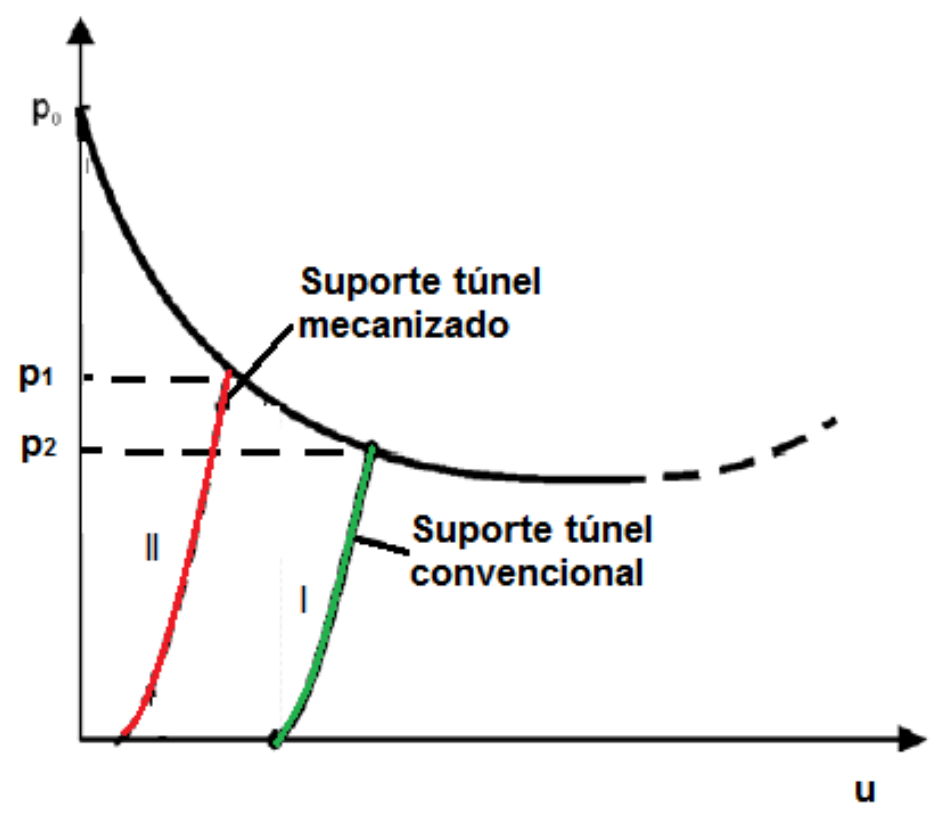

Fonte: autor.

Em linhas gerais, o método de convergência e confinamento é um instrumento básico para uma avaliação preliminar das tensões e deformações no maciço e na 
estrutura de suporte em várias distâncias da frente de escavação. Este método pode ser utilizado como uma estimativa inicial do carregamento atuante na estrutura, para definição da zona de plastificação do maciço ao redor da escavação e na estimativa das convergências internas no túnel. Entretanto, devido às hipóteses nas quais o método se baseia, a sua aplicação em túneis rasos, onde as tensões iniciais não podem ser consideradas hidrostáticas e uniformes, não é recomendada como solução única, mas sim comparativa para se ter uma ordem de grandeza dos esforços e deformações esperadas.

Em túneis rasos, o método das reações hiperestáticas, descrito a seguir, é o método analítico mais indicado para obtenção dos esforços solicitantes no revestimento.

\subsubsection{Método das reações hiperestáticas}

O método das reações hiperestáticas (também denominado método da viga apoiada em molas) foi inicialmente desenvolvido por Duddeck e Erdmann (1985) e simula a interação entre o revestimento e o solo ao redor do túnel por meio de molas do tipo Wrinkler independentes. Este método é denominado hiperestático por conta dos diversos apoios do revestimento no maciço, conforme ilustrado na Figura 3.20.

Figura 3.20 - Esquema de cálculo com o método das reações hiperestáticas.
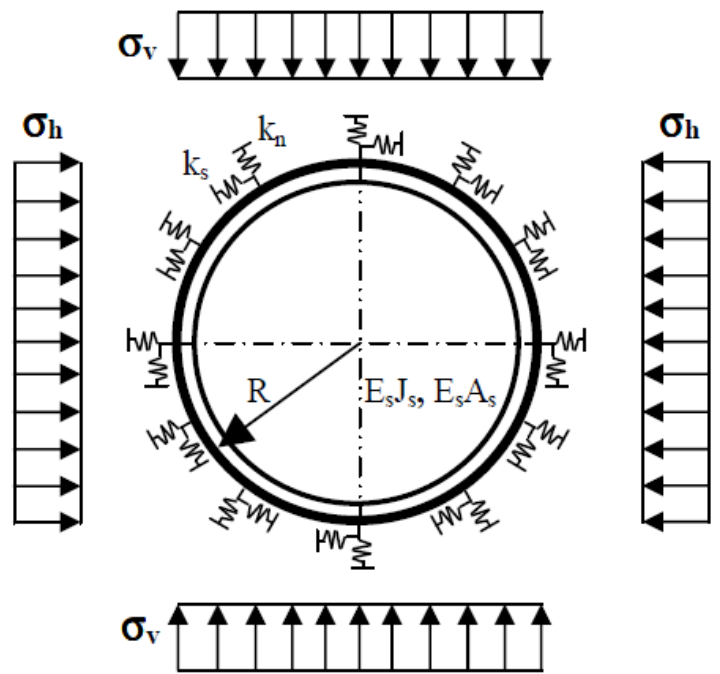

Fonte: Do (2014).

Este método exige a definição dos carregamentos ativos aplicados pelo solo diretamente no revestimento, além dos carregamentos passivos que ocorrem devido à reação do maciço ao deslocamento do revestimento. ITA (2000) define os 
carregamentos externos ativos que devem ser considerados no dimensionamento do revestimento (Figura 3.21): pressão exercida pelo maciço escavado $\left(p_{e}\right.$ e $\left.q_{e}\right)$, pressão hidrostática $\left(p_{w}\right)$, peso próprio $\left(p_{g}\right)$, sobrecarga $\left(P_{0}\right)$.

Figura 3.21 - Carregamentos ativos externos atuantes.

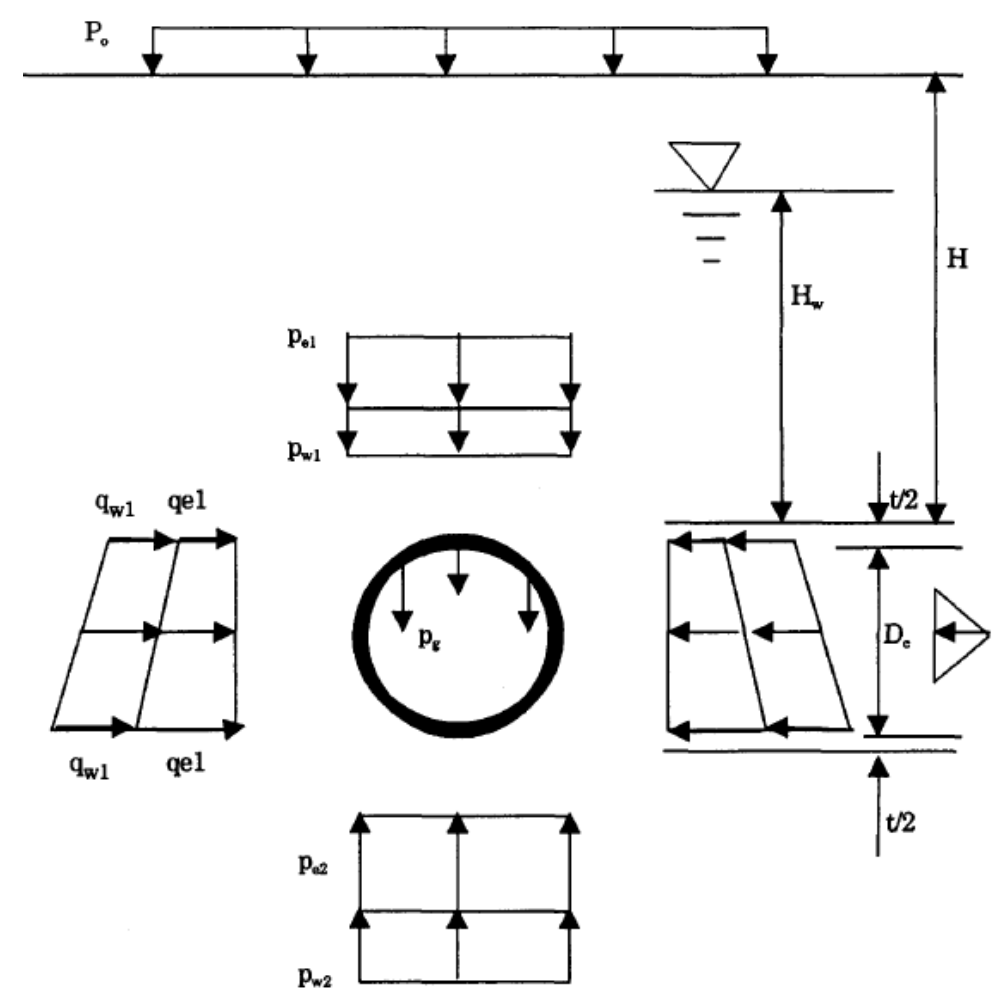

Fonte: ITA (2000).

Com relação ao carregamento do maciço, ITA (2000) define que este deve ser aplicado radialmente no revestimento ou dividido em carregamento vertical e horizontal. Neste último caso, deve-se diferenciar o carregamento vertical com base na profundidade do túnel, conforme apresentado anteriormente nas Equações (3.9) a (3.11). Já o carregamento horizontal é definido como o coeficiente de empuxo lateral (que deve ser um valor entre o coeficiente de empuxo em repouso e o coeficiente de empuxo ativo) multiplicado pelo carregamento vertical, sendo uniformemente variável com a profundidade.

A obtenção dos esforços solicitantes utilizando o método das reações hiperestáticas está baseada na subdivisão do revestimento em elementos unidimensionais que são conectados com o meio externo a partir de rigidezes distribuídas nos nós, podendo desenvolver momentos fletores, forças axiais e cisalhantes. Os elementos de viga são modelados com comportamento elástico-linear, definidos pelo módulo de inércia, 
a área da seção transversal, o módulo de elasticidade e o comprimento (distância entre os nós). Com estes parâmetros define-se a matriz de rigidez que é utilizada para o cálculo dos deslocamentos de cada nó.

A interação com o maciço se dá por meio de molas normais e transversais conectadas aos nós da estrutura (Figura 3.22) e pelos carregamentos aplicados. As molas normais permitem simular a reação produzida pelo maciço quando 0 revestimento, que se deforma devido à aplicação dos carregamentos ativos, se desloca. Já as molas tangenciais permitem que seja considerada a deformação tangencial do revestimento na direção circunferencial sob a ação dos carregamentos ativos aplicados.

Figura 3.22 - Molas conectadas aos nós do revestimento.

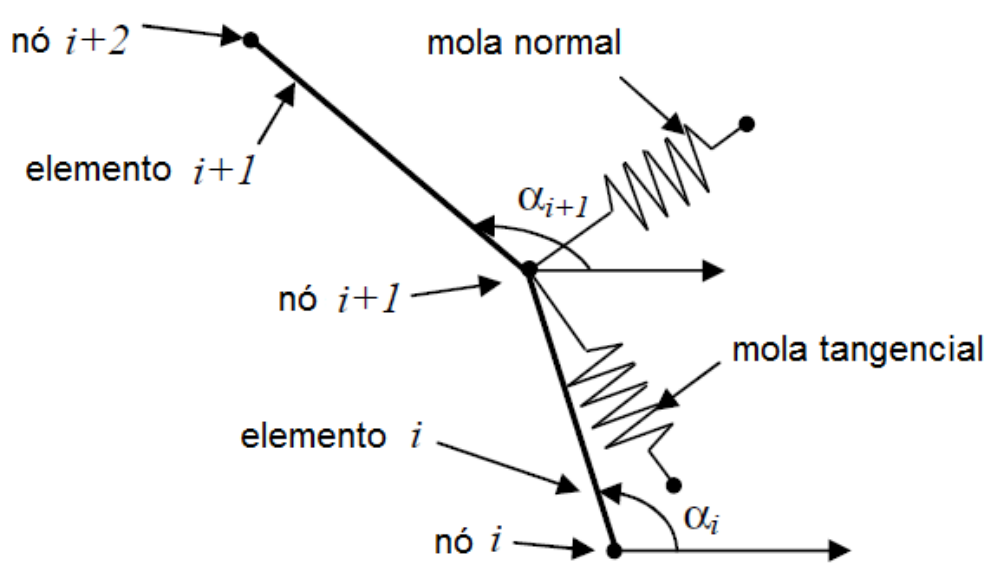

Fonte: Do (2014).

Determinam-se os valores das constantes normal $\left(K_{n}\right)$ e tangencial $\left(K_{t}\right)$ da mola com base na rigidez normal e tangencial do maciço. Para simular a reação do maciço, é introduzida uma relação não-linear entre a pressão de reação e o deslocamento do revestimento.

Um dos principais pontos positivos deste método é a simplicidade e rapidez dos cálculos necessários - Oreste (2007) e Do (2014) fornecem códigos matemáticos para a aplicação deste método, sendo que na formulação de Do (2014) é possível levar em conta a influência das juntas dos segmentos. Outra vantagem é a possibilidade de simular diferentes seções de escavação, o que não é possível nos demais métodos analíticos apresentados anteriormente. Já uma das desvantagens deste método reside na dificuldade de se estimar a rigidez das molas e as cargas aplicadas no revestimento. 
Com referência aos diferentes métodos analíticos de cálculo do revestimento, Do et al. (2014a) compararam os resultados de cálculo utilizando o método proposto por Einstein e Schwartz (1979), o método de Duddeck e Erdmann (1985) e dados de instrumentação de campo. Os resultados obtidos pelos dois métodos analíticos foram semelhantes, entretanto os esforços calculados foram inferiores aos medidos em campo, sendo que em campo foram medidos esforços até $100 \%$ superiores aos máximos esforços calculados. Os autores atribuem esta diferença à heterogeneidade do maciço e à influência de fatores construtivos, como pressão de grout e forças aplicadas pelos cilindros de avanços. Os autores citam ainda que esta mesma diferença contra a segurança foi também verificada em estudos anteriores, como de Bakker (2003), que comparou os resultados de métodos analíticos com resultados obtidos a partir de modelos numéricos, e Bilotta e Russo (2013), que também comparam resultados analíticos com medidas de campo, em um túnel raso. Os autores concluem que estes métodos analíticos fornecem resultados contra a segurança e por isso devem ser complementados por estudos adicionais e com a aplicação dos devidos fatores de segurança. 
4 SIMULAÇÕES NUMÉRICAS APLICADAS A TÚNEIS 


\section{SIMULAÇÕES NUMÉRICAS APLICADAS A TÚNEIS}

\subsection{INTRODUÇÃO}

Conforme apresentado no capítulo anterior, o estudo de túneis envolve um grande número de variáveis distintas. Por conta das complexidades destas variáveis, uma análise completa do problema só é possível com a utilização de métodos de análises numéricas. Estes são métodos aproximados que possibilitam a resolução de um conjunto de equações diferenciais ao qual um meio em equilíbrio deve satisfazer. Podem ser utilizadas algumas metodologias de cálculo, como: método dos elementos de contorno, método das diferenças finitas e método dos elementos finitos, sendo este último o mais usual.

Como exposto nas definições dos diversos métodos de cálculo analíticos apresentados no capítulo anterior, estes possuem limitações por conta das hipóteses iniciais adotadas, não permitindo em geral a representação de geometrias complexas, descontinuidades no maciço, estratos não homogêneos e não isotrópicos, por exemplo. A modelagem numérica permite a simulação destas condições com mais facilidade, além de oferecer resultados quanto à estabilidade da escavação, esforços no suporte e movimentos induzidos no terreno por meio de uma única análise. Além disso, o efeito da escavação de um túnel em estruturas na superfície ou enterradas (como edifícios, tubulações, estacas, paredes de contenção) pode ser mensurado com maior acurácia, assim como medidas para condicionamento do solo.

O sucesso da aplicação dos métodos numéricos na modelagem do comportamento de túneis depende de dois aspectos fundamentais: uma correta simulação de todas as etapas construtivas relevantes, como a sequência de escavação e o momento de instalação do suporte, pois esta consideração da metodologia construtiva influencia consideravelmente no comportamento mecânico do maciço; e o modelo constitutivo empregado para reproduzir o comportamento do maciço. Como o comportamento do solo é regido por diversas variáveis, os modelos constitutivos mais elaborados podem ser tão complexos que inviabilizam sua utilização, pois são necessários alguns parâmetros de entrada de difícil obtenção. Usualmente são utilizados modelos mais simples, cujos parâmetros de entrada podem ser obtidos com maior 
facilidade em ensaios de laboratório usuais, que permitem levar em consideração os comportamentos mais relevantes do solo para o estudo de túneis.

Neste capítulo serão apresentadas algumas considerações a respeito de modelagens bi e tridimensionais, com foco nas diferentes soluções disponíveis para aproximar um problema tridimensional em um modelo bidimensional. Serão estudadas também as distintas maneiras utilizadas para representação do revestimento do túnel nas simulações numéricas e serão avaliadas algumas limitações existentes nas modelagens que requerem atenção durante a elaboração dos modelos e ao analisar os resultados obtidos. Por fim, será apresentada a formulação básica dos modelos constitutivos que serão estudados neste trabalho.

\subsection{ANÁLISES NUMÉRICAS TRIDIMENSIONAIS}

Diferentemente da maior parte dos modelos analíticos, nas análises numéricas a metodologia executiva empregada na construção do túnel é fator condicionante no resultado da análise. Por isso, se faz necessário diferenciar uma escavação mecanizada com escudo e controle de pressão interna de uma escavação pela metodologia convencional. Uma boa análise numérica deve reproduzir da maneira mais consistente possível todas as etapas da construção.

Análises numéricas bi ou tridimensionais de túneis em solo já foram objeto de estudo de diversos autores, dentre os quais estão destacados nas Tabela 4-1 e Tabela 4-2 alguns trabalhos, divididos por metodologia executiva - túneis convencionais e mecanizados, respectivamente. No levantamento de estudos de túneis em solo executados pela metodologia convencional estão apresentadas apenas pesquisas nacionais. A vasta gama de dados de obra e instrumentação disponível sobre os túneis do Metrô de São Paulo possibilitou o desenvolvimento de diversas pesquisas, inclusive com a aplicação de distintos modelos constitutivos para o solo. Com relação às análises numéricas simulando escavação mecanizada em solo, até a elaboração deste trabalho não havia sido publicada pesquisa desenvolvida no Brasil a respeito este tema. Com relação a máquinas tuneladoras, há uma pesquisa nacional, um estudo desenvolvido por Castro (2013) sobre métodos para seleção de TBM, com uma análise numérica de uma escavação de um túnel de adução em rocha. 
Tabela 4-1 - Análises numéricas simulando escavação convencional.

\begin{tabular}{|c|c|c|c|c|}
\hline Autor & $\begin{array}{l}\text { Tipo de } \\
\text { análise }\end{array}$ & $\begin{array}{l}\text { Modelo } \\
\text { constitutivo do solo }\end{array}$ & $\begin{array}{l}\text { Tipo de solo } \\
\text { escavado }\end{array}$ & Caso de obra analisado \\
\hline $\begin{array}{l}\text { Parreira } \\
\text { (1991) }\end{array}$ & $2 \mathrm{D}$ & $\begin{array}{l}\text { EP de Lade, EPP } \\
\text { MC }\end{array}$ & $\begin{array}{l}\text { Argilas da } \\
\text { Formação SP }\end{array}$ & $\begin{array}{l}\text { Túnel Paraíso na Linha } \\
2 \text { do Metrô de SP }\end{array}$ \\
\hline Ruiz (1997) & $2 \mathrm{D}$ & EPP MC & $\begin{array}{l}\text { Argila porosa de } \\
\text { Brasília }\end{array}$ & $\begin{array}{l}\text { Túnel do Metrô de } \\
\text { Brasília }\end{array}$ \\
\hline França (2006) & $3 D$ & EPP MC e HS & $\begin{array}{l}\text { Argilas da } \\
\text { Formação SP }\end{array}$ & $\begin{array}{l}\text { Túnel Paraíso na Linha } \\
2 \text { do Metrô de SP }\end{array}$ \\
\hline Silva (2008) & $2 \mathrm{D}$ & EPP MC e CCM & $\begin{array}{l}\text { Argilas da } \\
\text { Formação SP }\end{array}$ & $\begin{array}{l}\text { Túnel Paraíso na Linha } \\
2 \text { do Metrô de SP }\end{array}$ \\
\hline Martins (2008) & 3D & EPP MC e HS & Argila & Caso genérico \\
\hline Cecílio (2009) & $3 D$ & EPP MC e HS & $\begin{array}{l}\text { Solo residual de } \\
\text { gnaisse }\end{array}$ & $\begin{array}{l}\text { Túnel na Linha } 4 \text { do } \\
\text { Metrô de SP }\end{array}$ \\
\hline
\end{tabular}

Fonte: autor

Tabela 4-2 - Análises numéricas simulando escavação mecanizada.

\begin{tabular}{lrlll}
\hline Autor & $\begin{array}{l}\text { Tipo de } \\
\text { análise }\end{array}$ & $\begin{array}{l}\text { Modelo } \\
\text { constitutivo do solo }\end{array}$ & $\begin{array}{l}\text { Tipo de solo } \\
\text { escavado }\end{array}$ & Caso de obra analisado \\
\hline $\begin{array}{l}\text { Hejazi, Dias e } \\
\text { Kastner (2008) }\end{array}$ & 2D & $\begin{array}{l}\text { EPP MC, HS e } \\
\text { HSS }\end{array}$ & $\begin{array}{l}\text { Argila de } \\
\text { Londres }\end{array}$ & $\begin{array}{l}\text { Túnel no aeroporto de } \\
\text { Londres }\end{array}$ \\
$\begin{array}{l}\text { Möller e } \\
\begin{array}{l}\text { Vermeer } \\
(2008)\end{array}\end{array}$ & 2D & HS e HSS & Areia & $\begin{array}{l}\text { Túnel Heinenoord na } \\
\text { Holanda }\end{array}$ \\
$\begin{array}{l}\text { Dias e Kastner } \\
(2013)\end{array}$ & 2D e 3D & EPP MC & Silte argiloso & Metrô de Lyon \\
$\begin{array}{llll}\text { Do (2014) } & \text { 2D e 3D } & \text { EPP MC e CYS } & \text { Argila arenosa }\end{array}$ & Túnel Bolonha-Florença \\
\hline
\end{tabular}

Fonte: autor

Siglas utilizadas nas Tabela 4-1 e Tabela 4-2:

- CCM: Cam-clay modificado;

- CYS: Cap yield soil, elastoplástico com endurecimento contido no programa FLAC;

- EP: elastoplástico;

- EPP: elastoplástico perfeito;

- HS: Hardening soil, elastoplástico com endurecimento disponível no programa PLAXIS;

- HSS: Hardening soil small strain, aperfeiçoamento do modelo Hardening soil;

- MC: Mohr-Coulomb. 
Independentemente da metodologia construtiva e do tipo de suporte utilizado, 0 processo de escavação de um túnel é de natureza tridimensional e por isso sua modelagem mais precisa é por meio de um modelo em três dimensões capaz de reproduzir de forma realista a distribuição de tensões e deslocamentos no maciço envolvente e no suporte após cada etapa da escavação.

Os programas de elementos finitos atuais permitem simular passo-a-passo uma escavação mecanizada, conforme realizado por Do (2014), Dias e Kastner (2013) e Mollon; Dias e Soubra (2013). A seguir estão descritas as etapas da simulação do avanço da tuneladora utilizadas por estes autores, levando em conta da melhor maneira possível os componentes e procedimentos que ocorrem em uma escavação real:

- Escavação do solo com aplicação simultânea da pressão de confinamento: determina-se o passo de avanço, equivalente à largura do anel, e simula-se a aplicação da pressão de frente calculada por meio de um perfil trapezoidal levando em conta a densidade da pasta na câmara (entre 12 e 16 kN/m³). Em complemento, aplica-se uma pressão radial nos primeiros metros atrás da face, para simular a pressão atuante no perímetro da escavação. Mollon, Dias e Soubra (2013) observam que devido à leve sobreescavação das ferramentas de corte periféricas e ao formato troncocônico do escudo, uma parte da pasta da câmara pode migrar para trás da cabeça de corte, exercendo uma pressão do perímetro da escavação que se dissipa em função da distância da frente. Na Figura 4.1 é mostrado um corte longitudinal esquemático da aplicação destas forças, em uma modelagem com diâmetro de escavação de 9,4 m.

- A modelagem do escudo pode ser feita de diversas maneiras: por elementos de casca com as propriedades do aço - módulo de elasticidade de $200 \mathrm{GPa}$, coeficiente de Poisson de 0,25 e densidade de $7840 \mathrm{~kg} / \mathrm{m}^{3}$, conforme realizado por Chakeri et al. (2013); por elementos sólidos de volume, com seu peso unitário sendo a razão entre o peso total do escudo e seu volume aparente, acrescentando uma camada de interface entre o escudo e o solo para permitir o desenvolvimento de forças de contato, conforme realizado por Kasper e Meschke (2004); pela introdução de um escudo fictício, por meio da determinação que os elementos representando o solo ao se deformarem não podem penetrar no escudo. Neste método, em cada etapa da escavação a posição da envoltória do escudo fictício é calculada e cada nó 
do solo localizado no contorno deste escudo fictício é fixado artificialmente, conforme realizado por Mollon; Dias e Soubra (2013) e Do (2014).

Figura 4.1 - Exemplo dos componentes e forças simulados em uma modelagem tridimensional de uma tuneladora.

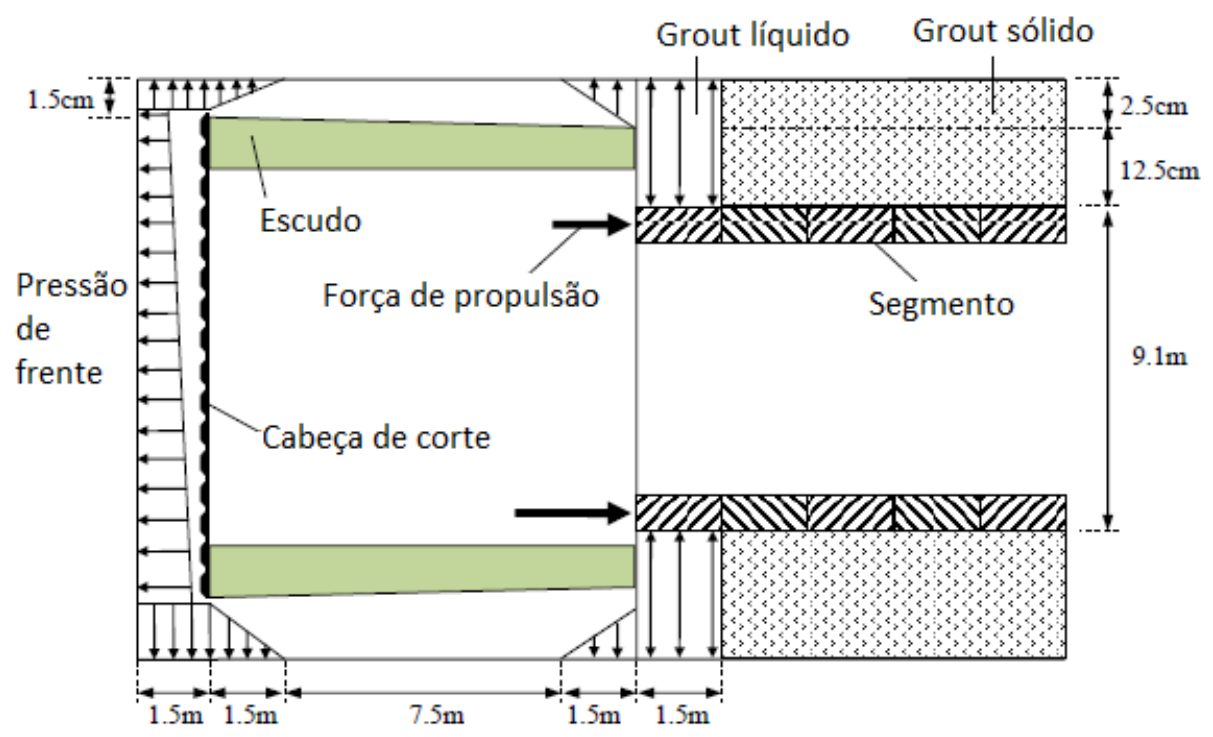

Fonte: adaptado de Do (2014).

- Modelagem da força de propulsão: trata-se de um importante carregamento nos anéis de revestimento. A distribuição da força aplicada pelos macacos não é igual ao longo da altura da máquina - a força aplicada é superior no invert do túnel. Representa-se esta força como cargas aplicadas pontualmente, crescentes linearmente com a profundidade, normalmente com 3 pontos de aplicação por segmento. A magnitude da carga depende do empuxo total instalado na máquina. $\mathrm{Na}$ Equação (4.1) é apresentada uma formulação empírica que relaciona o empuxo total da máquina $\left(E_{\text {máx }}\right)$ em kN com o diâmetro da escavação $(D)$, por meio de um fator $\beta$ que pode variar entre 700 e 1200 em função do tipo de solo.

$E_{\text {máx }}=\beta \cdot D^{2}$

- Injeção do grout: em um primeiro momento, o grout é modelado no estado líquido, com a aplicação de uma pressão radial no solo e nos anéis de revestimento. Usualmente a pressão aplicada é ligeiramente superior à pressão de frente, para levar em conta as perdas de carga do processo de injeção e para permitir que o grout se espalhe no vazio anelar com mais facilidade. Este processo é representado por uma pressão distribuída que aumenta linearmente com a profundidade devido ao peso específico do grout. Assim como no caso da pressão de frente, é possível que 
parte da pressão do grout atue na parte final do escudo, se dissipando na direção da frente da máquina, conforme representado na Figura 4.1.

- Endurecimento do grout: em um segundo momento, o grout passa para o estado sólido e deixa de exercer pressão contra o solo. Nesta etapa, o grout pode ser representado por elementos de volume com comportamento elástico. Mollon; Dias e Soubra (2013) adotam módulo de elasticidade de 10 MPa e coeficiente de Poisson de 0,22 para representar o grout no estado endurecido. Uma representação mais precisa do efeito do grouteamento seria por meio de um modelo constitutivo que levasse em conta o efeito da viscosidade do grout, que permitisse simular a passagem da etapa viscosa para a sólida.

- Anéis de revestimento: os segmentos que compõe o anel são modelados como elementos com comportamento elástico-linear. Em uma simulação mais completa, conforme realizado por Do (2014), é possível modelar as juntas entre os segmentos como rótulas com rigidezes rotacional, axial e radial representadas por meio de molas. As juntas longitudinais entre os anéis são representadas por conectores com rigidezes equivalentes. Para se ter maior precisão, pode-se variar também a posição das juntas. Mais informações sobre a modelagem das juntas são apresentadas no item 4.4. A determinação da rigidez das juntas é feita com base no procedimento definido por Thienert e Pulsfort (2011) e será detalhado e aplicado no item 5.

Somente uma modelagem tridimensional permite estimar um perfil longitudinal de recalques e também avaliar com acurácia o efeito da variação da posição e das propriedades das juntas entre segmentos ao longo do túnel, como por exemplo a não coincidência de juntas em dois anéis seguidos na longitudinal. Para exemplificar um resultado obtido em análise tridimensional, é ilustrada na Figura 4.2 uma estimativa dos recalques longitudinais realizada por Mollon, Dias e Soubra (2013).

É possível observar o efeito de diversas etapas da escavação, como a passagem da frente e a injeção do grout. O resultado obtido vai ao encontro das observações de Guglielmetti et al. (2008) de casos reais, conforme citado no item 3.2.1. Observa-se que aproximadamente $30 \%$ do recalque superficial estimado ocorre antes da passagem da frente de escavação pela seção, enquanto que a maior parte do recalque ocorre quando da passagem do escudo e injeção do vazio anelar. Os autores destacam que o soerguimento registrado na profundidade de $10 \mathrm{~m}$ durante a 
injeção do grout pode estar relacionado com o modelo constitutivo utilizado para o solo. Os autores utilizaram um modelo elastoplástico perfeito com critério de ruptura de Mohr-Coulomb. Se fosse utilizado um modelo que permitisse adotar uma rigidez distinta no descarregamento, o efeito observado poderia ser amenizado.

Figura 4.2 - Recalques longitudinais estimados em modelagem tridimensional obtidos por Mollon; Dias e Soubra (2013).

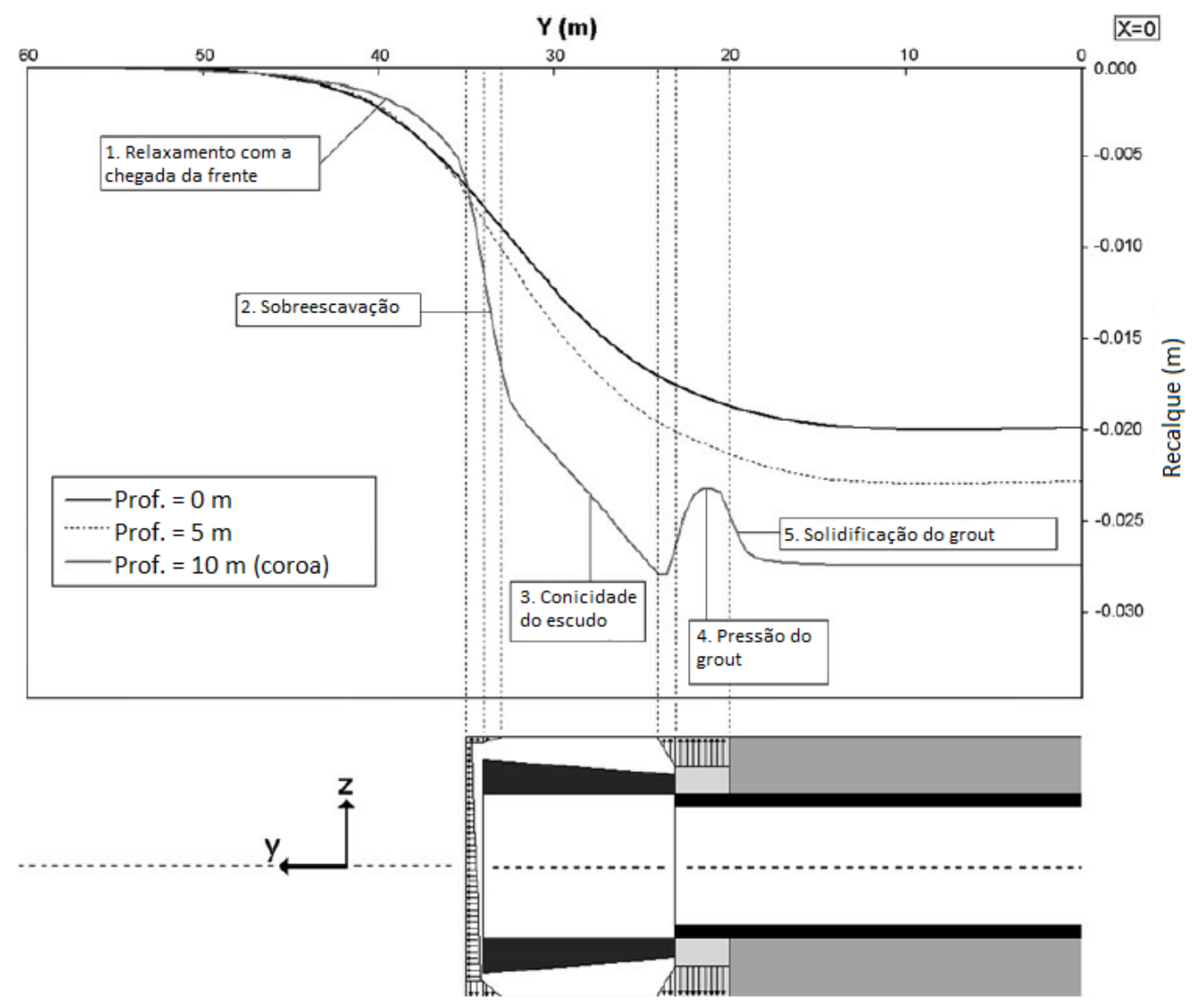

Fonte: adaptado de Mollon; Dias e Soubra (2013).

\subsection{ANÁLISES NUMÉRICAS BIDIMENSIONAIS - MÉTODOS DE CÁLCULO}

Apesar das vantagens de um modelo tridimensional citadas anteriormente, existem algumas dificuldades no seu desenvolvimento, tais como: tempo necessário para preparação do modelo, excessivos requisitos computacionais de processamento e armazenamento, dificuldade na confecção de malhas, na obtenção dos dados e tratamento dos resultados. Para exemplificar, cada modelagem tridimensional realizada por Do (2014) levou, segundo o autor, em média 190 horas para ser processada. Por conta disso, análises bidimensionais em estado plano de 
deformações que permitem introduzir, mesmo que de forma aproximada, o efeito tridimensional da escavação, são de grande utilidade.

Existem diversos métodos para converter um problema tridimensional em um problema plano, os quais adotam algumas premissas que levam em conta, por exemplo, perda de solo, alterações nas propriedades do maciço e deformações da área escavada antes da instalação do revestimento do túnel. Negro e Queiroz (1999) realizaram um amplo levantamento de publicações técnicas avaliando entre outros critérios o método de cálculo utilizado nas análises numéricas. Um levantamento e descrições dos métodos disponíveis mais conhecidos são apresentados a seguir.

\subsubsection{Método do alívio de tensões}

Trata-se da aplicação do método de convergência e confinamento descrito no item 3.3.1.1. De acordo com esta metodologia, a redução da tensão radial $\sigma_{r}$ no perímetro da escavação simula o efeito tridimensional do avanço do túnel de acordo com a relação apresentada na Equação (4.2), exemplificada nas Figuras 4.3 e 4.4.

Figura 4.3 - Variação da tensão radial durante a escavação.

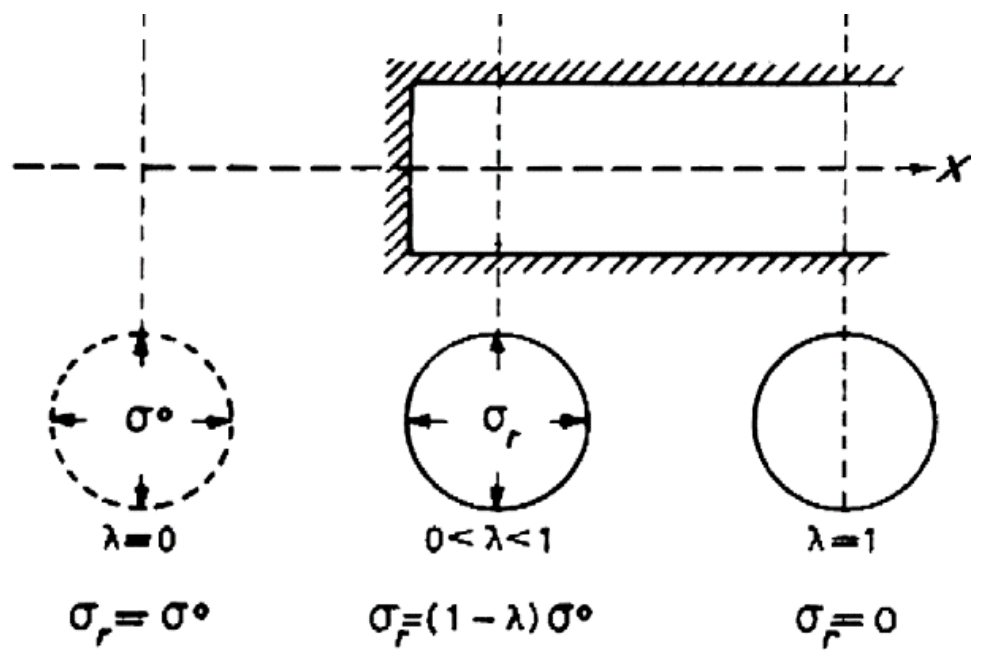

Fonte: adaptado de Panet e Guenot (1982).

$\sigma_{r}=(1-\lambda) \cdot \sigma_{0}$

Sendo $\lambda$, que varia de 0 a 1 , um fator de redução da tensão inicial in situ $\left(\sigma_{0}\right)$. À medida que a escavação avança pela seção em análise, a tensão radial aplicada na circunferência da escavação é reduzida gradativamente em etapas, até que seja atingido o valor de $\lambda$ pré-determinado. Neste momento o sistema de suporte da 
escavação é ativado e na sequência o alívio total $(\lambda=1)$ é aplicado, ou seja, não existem mais forças internas fictícias atuantes.

Figura 4.4 - Representação do fator de alívio.

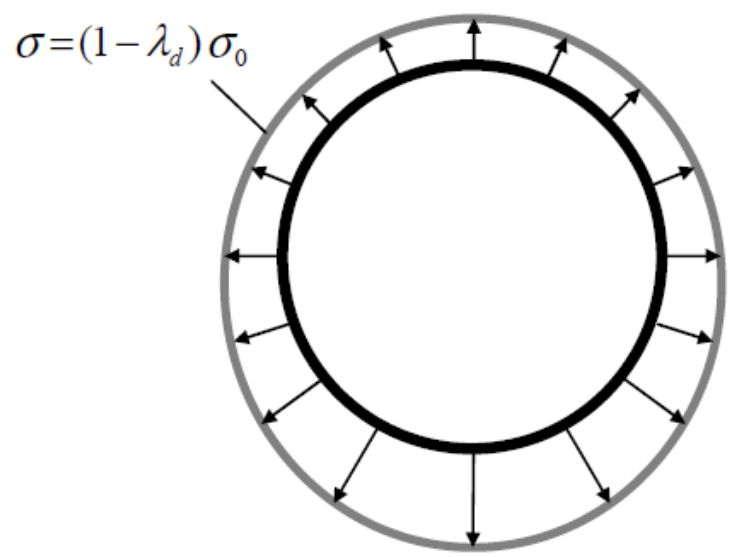

Fonte: adaptado de Hejazi, Dias e Kastner (2008).

Análises numéricas bidimensionais utilizando o método de alívio de tensões são amplamente utilizadas. França (2006), Silva (2008) e Cecílio (2009) realizaram análises deste tipo na simulação de túneis em NATM. Hejazi, Dias e Kastner (2008), Dias e Kastner (2013) e Do et al. (2014b) utilizaram esta metodologia para simular uma escavação mecanizada. Em geral, estes trabalhos apontam que, em certas condições geotécnicas e de execução, o método de alívio de tensões pode reproduzir corretamente o recalque superficial medido em campo após a conclusão dos túneis. Contudo, é necessário estimar a priori o fator de redução $\lambda$, que é geralmente especificado com base em retroanálises. França (2006) e Cecílio (2009), em modelos tridimensionais simulando um túnel convencional, observaram uma marcante variação do fator de alívio em diferentes partes do túnel, podendo levar a resultados com esforços superestimados no arco invertido e recalques subestimados na superfície. Já Vermeer et al. (2002) efetuaram uma verificação semelhante em uma simulação tridimensional de um túnel escavado mecanicamente. Os autores obtiveram um fator de alívio constante em todo o contorno da escavação, indicando assim que este método é adequado para a simulação de túneis mecanizados.

Em estudos comparativos entre diferentes métodos de análise numérica para simular a escavação de um túnel (Karakus, 2007, Hejazi, Dias e Kastner, 2008, Dias e Kastner, 2013, e Do et al., 2014b), foi obtida com o método do alívio de tensões uma melhor aproximação de bacias de recalques medidas em campo, em 
comparação com resultado de análises tridimensionais. Com relação à estimativa dos esforços solicitantes, Möller e Vermeer (2008) e Do et al. (2014b) observam que os momentos fletores obtidos em análises com o método do alívio de tensões são condizentes com os resultados de análises tridimensionais e de medições em campo. Contudo, os autores observam que o método do alívio estima esforços normais inferiores aos calculados por método. Do et al. (2014b) apontam ainda a influência da modelagem das juntas entre os segmentos nos resultados obtidos, o que será explorado em mais detalhes no item 4.4 e nas simulações numéricas do item 5.

\subsubsection{Método do amolecimento do núcleo}

O método do amolecimento do núcleo, também conhecido como método de redução da rigidez, introduzido por Swoboda (1979), considera uma redução no módulo de elasticidade original do maciço $\left(E_{0}\right)$ na área de escavação do túnel por meio da aplicação de um fator empírico $\alpha$, conforme a Equação (4.3), onde $E_{r}$ representa o módulo de elasticidade adotado após o amolecimento.

$E_{r}=\alpha \cdot E_{0}$

O processo consiste em simular a aproximação da frente de escavação na seção em estudo por meio do amolecimento sequencial da rigidez da porção de solo a ser escavada, atingindo o amolecimento total (desativação da camada escavada) quando ocorre a instalação do revestimento do túnel. $O$ amolecimento prévio do núcleo permite que ocorram as deformações esperadas com a aproximação da frente até que um novo equilíbrio seja atingido, sem a necessidade de impor um fator de redução das tensões.

Para aplicação deste método, são utilizadas camadas de elementos sobrepostas umas às outras, compartilhando os mesmos pontos nodais da região a ser escavada. A soma algébrica da rigidez de cada camada será igual à rigidez total do conjunto, que por sua vez equivale à rigidez original do maciço. $O$ amolecimento é simulado removendo sequencialmente cada camada.

Este método tem como dificuldades a definição da rigidez parcial de cada camada de solo e a determinação do fator de redução da rigidez. De acordo com Silva 
(2008), para a correta aplicação do método é necessário estabelecer uma relação entre o histórico de deslocamentos com o avanço da frente de escavação e definir uma função normalizada para esta relação. $O$ autor apresenta um caso de aplicação desta metodologia descrito em Ohnishi et al. (1982), onde definiu-se com sucesso a partir de um histórico de deslocamentos a curva normalizada de rigidez para determinar a relação da redução da rigidez pelo avanço da frente. Outras referências onde foi utilizada esta metodologia constam em Negro e Queiroz (1999).

\subsubsection{Método do módulo de elasticidade hipotético do revestimento}

Neste método, valores de módulo de elasticidade hipotéticos predeterminados do revestimento são introduzidos em diferentes etapas da simulação numérica para considerar o efeito da deformação do maciço antes da instalação do suporte e até que este atinja sua resistência total. Este método foi aplicado por Powell et al. (1997) e Karakus e Fowell (2003) para similar escavação de túneis na argila de Londres. Trata-se de uma metodologia aplicável a túneis convencionais, pois um ponto fundamental deste tipo de análise é o ganho de resistência e rigidez do revestimento com o passar do tempo e das etapas da simulação, característica essa essencial do concreto projetado utilizado no revestimento de túneis convencionais. A Figura 4.5 ilustra o princípio de aplicação deste método.

Figura 4.5 - Representação do método do módulo de elasticidade hipotético do revestimento.

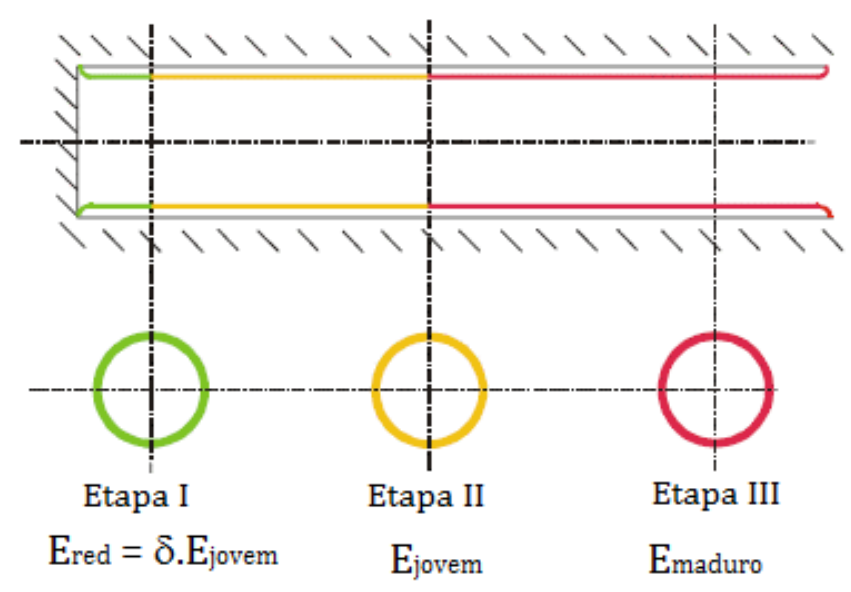

Fonte: adaptado de Karakus (2007).

De acordo com esta metodologia, na primeira etapa do cálculo, antes da etapa de escavação do túnel, o revestimento é aplicado com uma rigidez reduzida, 
correspondente à rigidez em seu estado jovem minorada por um fator $\delta$, que varia de acordo com os parâmetros de resistência do solo, formato do túnel e o número de etapas de escavação. Segundo Karakus e Fowell (2003), este fator esteve entre 0,02 e 0,1 para as argilas sobreadensadas de Londres e pode ser determinado a partir de retroanálises quando se dispõe de dados de instrumentação de obra.

Na segunda etapa, o solo é escavado e o módulo de elasticidade considerado é o módulo do concreto projetado jovem, geralmente entre 5 e $10 \mathrm{GPa}$. Na sequência, na terceira etapa o revestimento atinge sua resistência e rigidez total. $O$ avanço do túnel representado em cada etapa depende da velocidade da escavação, do processo de construção e do tempo de ganho de resistência do concreto projetado.

\subsubsection{Método do vazio imposto}

Este método foi introduzido por Rowe et al. (1983) e consiste em estabelecer um vazio predefinido na malha de elementos finitos, o qual representa a perda de solo total esperada, já levando em conta na estimativa o efeito tridimensional da escavação no maciço assim como outros fatores, como método construtivo e qualidade da construção, por exemplo. O vazio é inserido ao redor da posição final do túnel, tendo o valor máximo na coroa do túnel e um valor nulo na base, de acordo com a Figura 4.6.

Figura 4.6 - Representação do método do vazio imposto

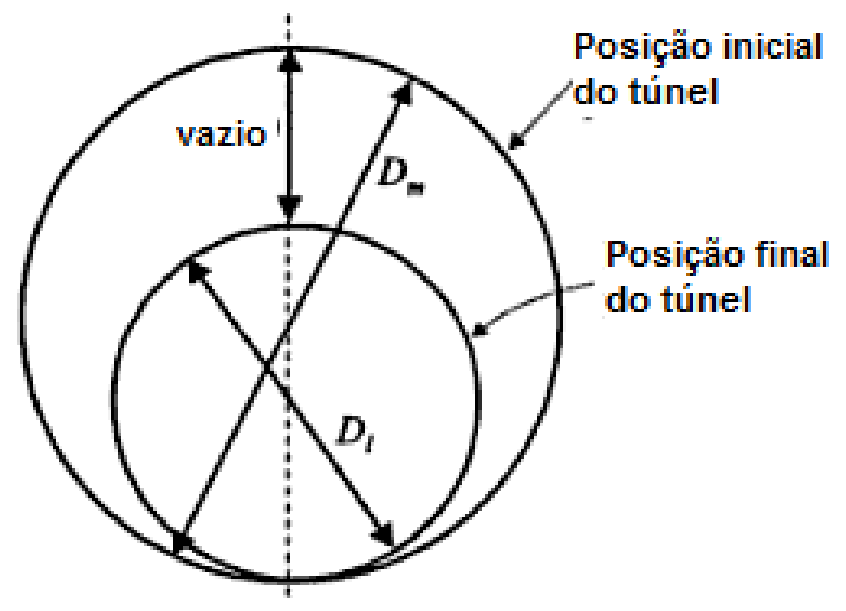

Fonte: adaptado de Potts e Zdravkovic (2001).

Karakus (2007) afirma que é possível obter resultados razoáveis com este método, sendo que a principal dificuldade é a definição da altura do vazio. Utilizando a ideia 
de o volume de perda de solo estimado ser um parâmetro de entrada na análise, foi desenvolvido o método da contração, descrito a seguir, que tem como vantagem uma maior possibilidade de controle dos parâmetros de entrada e facilidade de aplicação do que o método do vazio imposto.

\subsubsection{Método da contração (ou método do controle da perda de volume)}

Este método pode ser considerado uma combinação entre o método do alívio de tensões e o método do vazio imposto, conforme apresentado por Addenbrooke et al. (1997) e aplicado nas análises de Hejazi, Dias e Kastner (2008) e Do (2014). Neste tipo de análise, é realizado um controle do deslocamento radial do contorno da escavação, permitindo que a área do túnel seja reduzida até que seja atingido um valor pré-determinado de contração. Há duas maneiras de se aplicar este método: mantendo o centro do túnel fixado, o que resultará na manutenção do contorno circular do túnel após a contração (Figura 4.7a); ou trabalhando com as bordas livres, ou seja, permitindo que o contorno da escavação se mova livremente até que o percentual de contração pré-estabelecido seja atingido, sem fixar a posição do centro do túnel (Figura 4.7b). A primeira maneira representa uma situação em que a tensão vertical é igual à tensão horizontal aplicada $\left(\mathrm{k}_{0}=1\right)$. Para casos gerais, a segunda maneira é mais adequada para representar a interação entre os deslocamentos do solo e do revestimento. Na Figura 4.7 consta a definição do percentual de contração.

Figura 4.7 - Representação do método da contração.

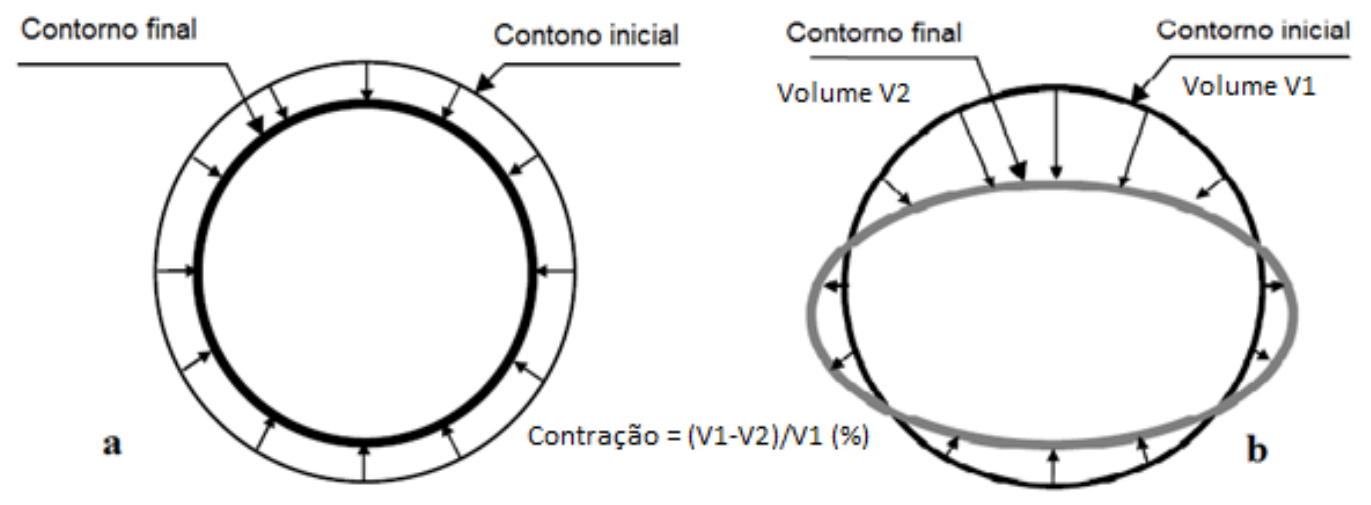

Fonte: adaptado de Do (2014). 
Este método é utilizado exclusivamente em modelagens de escavações mecanizadas, pois só é possível aplicá-lo em escavações com formato inicial circular. Além disso, pode-se dizer que a contração da área de escavação é uma representação do que de fato ocorre durante a escavação mecanizada - redução do diâmetro final acabado da escavação devido ao formato cônico do escudo e da diferença entre o diâmetro externo dos anéis e da escavação pela cabeça de corte.

\subsubsection{Método da pressão de grout}

Möller e Vermeer (2008) descrevem um método de cálculo específico para escavações mecanizadas, que inclui na análise a representação da injeção de grout e sua respectiva pressão. Os autores realizaram uma modelagem levando em conta uma camada de elementos de interface que simulam o volume de grout que preenche o vazio anelar (ilustrado na Figura 2.14). Os autores observam que entre o instante da escavação, onde a frente está pressurizada, e a injeção do grout todo movimento possível no maciço é limitado à espessura do espaço anelar, o que influencia diretamente na perda de solo da escavação.

Antes da escavação do túnel, os elementos que representam o espaço anelar estão sob o estado inicial de tensões in situ. Na etapa da injeção do grout, uma pressão radial $\sigma_{g}$ é aplicada nos elementos, incluindo um incremento hidrostático com a profundidade considerando o peso específico do grout $\left(15 \mathrm{kN} / \mathrm{m}^{3}\right)$, conforme mostrado na Figura 4.8.

Figura 4.8 - Representação da injeção de grout.

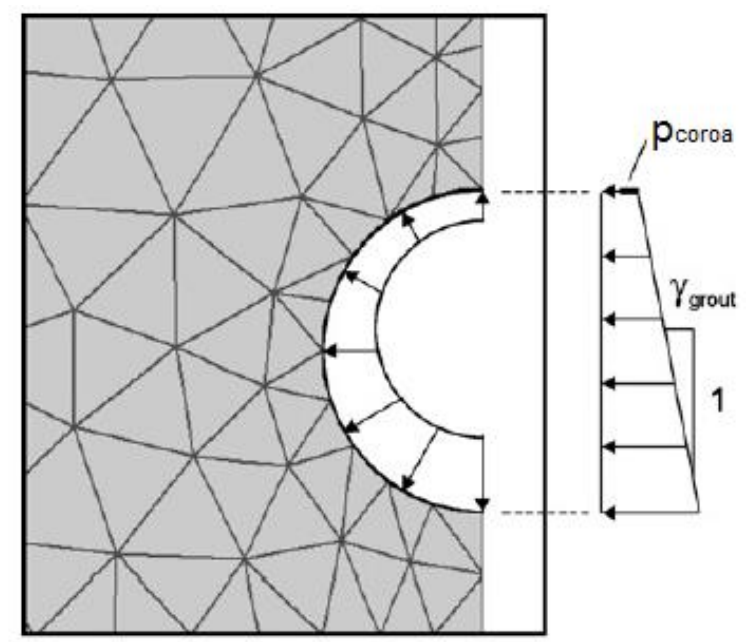

Fonte: adaptado de Möller e Vermeer (2008). 
A transição entre o estado inicial de tensões $\sigma_{0}$ e a aplicação da pressão do grout $\sigma_{g}$ é realizada de acordo com a Equação (4.4), onde $\beta$ representa um fator de transição que vai de 0 a 1 . Neste método, a pressão de injeção de grout é um dos dados de entrada para o modelo. Entretanto, quando não se conhece a pressão do grout é possível defini-la iterativamente com base em um volume de perda de solo admissível ou esperado.

$\sigma=(1-\beta) \cdot \sigma_{0}+\beta \cdot \sigma_{g}$

Nos resultados obtidos nas análises, Möller e Vermeer (2008) observam que a bacia de recalque calculada é muito sensível a pequenas variações nas pressões de injeção adotadas. Segundo os autores, em comparação com outros métodos de cálculo (alívio de tensões e contração), o método da pressão do grout apresentou um formato da bacia de recalque mais condizente com a que foi medida em campo. O cálculo pelos outros dois métodos apresentou bacias de recalque mais largas para o mesmo recalque máximo, o que implica em diferentes perdas de solo obtidas entre os métodos avaliados.

Os autores destacam também que os esforços solicitantes obtidos nas análises utilizando o método da pressão do grout estiveram mais próximos das medidas em campo, mesmo ressaltando que a obtenção das medições em campo não é simples, realizada por meio de retroanálise de leituras de extensômetros e células de pressão. Os esforços solicitantes, principalmente as forças normais, calculados pelo método do alívio de tensões foram ligeiramente inferiores aos determinados pelos outros dois métodos e por isso os autores observam que pode ser necessária a utilização de diferentes fatores de alívio $\lambda$ para se obter melhores estimativas de recalques e esforços no revestimento.

\subsection{ANÁLISES NUMÉRICAS - MODELAGEM DO REVESTIMENTO}

Nos revestimentos de túneis com anéis segmentados, o comportamento da estrutura é influenciado não somente pelas características do concreto, mas também pelas características mecânicas e geométricas das juntas de articulação entre os segmentos, na direção longitudinal e circunferencial. Diversos estudos foram realizados com o intuito de simular com maior precisão o comportamento destas 
juntas e sua influência nos esforços solicitantes do revestimento: análises bidimensionais (Hefny e Chua, 2006, Do et al., 2013a), análises tridimensionais (Klappers et al, 2006, Do, 2014) e ensaios físicos em escala real (Arnau e Molins, 2011a e 2011b).

$\mathrm{Na}$ modelagem numérica, o efeito da junta entre os segmentos pode ser considerado de duas maneiras: pelo método indireto, onde o revestimento é modelado como um elemento contínuo e é aplicado um fator de redução da rigidez na estrutura; ou pelo método direto, acrescentando elementos de junta diretamente no modelo, usualmente uma articulação, com possibilidade de aplicação de rigidez rotacional, axial e cisalhante (Do, 2014).

O fator de redução da rigidez aplicado no método indireto pode ser determinado empiricamente, analiticamente ou experimentalmente. A solução proposta por MuirWood (1975), apresentada na Equação (3.23), é um exemplo de aplicação. Por se tratar de um método mais simples e de fácil utilização, a metodologia indireta é muito utilizada. Com este método, contudo, não é possível realizar avaliações mais detalhadas, como por exemplo, o efeito da posição e orientação das juntas nos esforços solicitantes. Neste caso, é preciso realizar uma análise pelo método direto.

Como mencionado anteriormente, há dois tipos de juntas: as longitudinais - entre dois segmentos do mesmo anel - e as radiais ou circunferenciais - entre dois anéis. Em análises bidimensionais é possível modelar somente as juntas longitudinais, como articulações ou rótulas com ou sem a transmissão de esforços. A avaliação do efeito das juntas radiais só é possível em modelos tridimensionais.

Em uma análise numérica bidimensional utilizando elementos finitos, Hefny e Chua (2006) estudaram a influência do número, posição e orientação das juntas circunferenciais nos momentos fletores solicitantes em um túnel segmentado com $6,0 \mathrm{~m}$ de diâmetro. Realizam também análises paramétricas variando o $k_{0}$ entre 0,5 , 1,0 e 2,0 e a profundidade do túnel (razão profundidade-diâmetro de 1,0 a 3,5) para avaliar a influência destes parâmetros em conjunto com as juntas nos momentos fletores solicitantes. Os autores modelaram as juntas como totalmente articuladas, ou seja, sem capacidade de transmissão de momentos de um segmento ao outro.

Os resultados obtidos, apresentados na Figura 4.9, mostram que a quantidade de juntas no revestimento exerce uma grande influência nos esforços solicitantes, 
sendo que a cada junta acrescentada o momento fletor máximo atuante nos segmentos é reduzido aproximadamente pela metade. Além disso, foi possível verificar também o efeito da posição das juntas nos esforços, principalmente no caso de 4 juntas, onde foi obtido um momento fletor máximo muito baixo (20 kNm) quando a junta estava posicionada na coroa do túnel $\left(0^{\circ}\right.$ em relação ao eixo vertical), enquanto que a junta posicionada a $45^{\circ}$ do eixo vertical do túnel propiciou um momento fletor máximo mais alto $(180 \mathrm{kNm})$.

Figura 4.9 - Variação no momento máximo em função da quantidade e posição das juntas
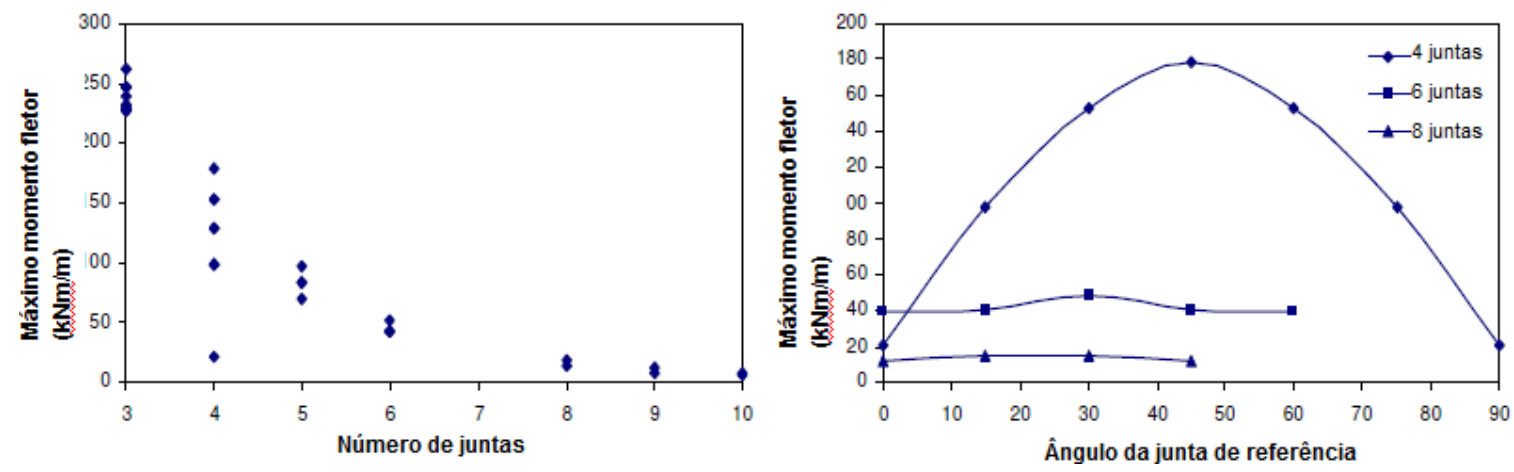

Fonte: adaptado de Hefny e Chua (2006).

Com relação à análise paramétrica, Hefny e Chua (2006) verificaram que o máximo esforço ocorre na situação com $k_{0}=2$, sendo que o menor valor foi obtido para $k_{0}=$ 1. É interessante notar no gráfico da Figura 4.10 que os momentos fletores estimados nas análises com revestimento contínuo foram muito superiores aos obtidos com o revestimento segmentado, a partir de 4 segmentos. Esta grande diferença foi notada também na análise com variação da profundidade do túnel. Estes resultados mostram a importância de simular as juntas no revestimento ou de se aplicar um fator de redução nos resultados obtidos com o revestimento contínuo.

Figura 4.10 - Variação no momento máximo em função de $k_{0}$ e da profundidade.
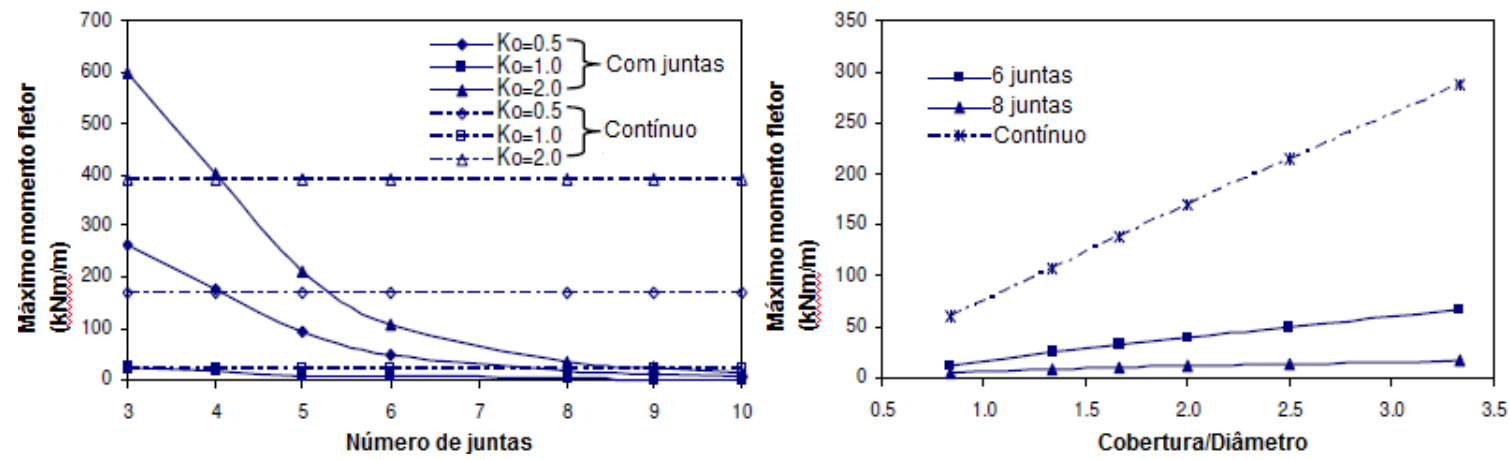

Fonte: adaptado de Hefny e Chua (2006). 
Klappers et al. (2006) realizaram uma análise em um modelo tridimensional simulando os segmentos por elementos de casca e as juntas por meio de molas rotacionais, com ou sem transferência de esforços entre os segmentos, na direção longitudinal e radial. Na simulação com transferência de esforços, a rigidez rotacional das juntas longitudinais é dada pela relação não-linear entre o momento fletor atuante e o ângulo de rotação na junta. Esta relação é obtida a partir da formulação proposta por Janssen (1983, apud Klappers et al., 2006), que divide o comportamento da junta em duas etapas. Enquanto a junta está completamente comprimida, a relação entre o momento atuante $(M)$ e o ângulo de rotação $(\alpha)$ é considerada constante, expressa pela Equação (4.5), dependendo somente do módulo de elasticidade do concreto $(E)$, da altura $(h)$ e largura $(b)$ da área de contato da junta. Se o momento fletor atuante na ligação ultrapassar o momento limite definido pela Equação (4.6) a junta começa a se abrir, reduzindo assim sua rigidez à rotação. A relação entre $\alpha$ e $M$ passa a ser calculada pela Equação (4.7).

$$
\begin{aligned}
& \alpha=12 \cdot M / E \cdot h^{2} \cdot b \\
& M_{\text {limite }}<N \cdot b / 6 \\
& \alpha=\frac{9 \cdot b \cdot h \cdot E \cdot(2 \cdot M / N \cdot h-1)^{2}}{8 \cdot N}
\end{aligned}
$$

Nos resultados obtidos os autores verificaram uma notável diferença nas deformações do revestimento e momentos fletores atuantes: na simulação sem transferência de esforços pelas juntas, cada segmento se deforma independentemente. Quando há transferência de esforços, a deformação é mais harmônica. Os momentos fletores máximos obtidos com a transferência de esforços foram quase $30 \%$ superiores do que sem a transferência de esforços pelas juntas.

Arnau e Molins (2011a, 2011b) realizaram verificações semelhantes às feitas por Klappers et al. (2006), entretanto a modelagem foi realizada em conjunto com um ensaio em escala real, onde os autores montaram 15 anéis reforçados com fibra de aço com 1,8 m de comprimento, diâmetro externo de 11,6 m e espessura de $35 \mathrm{~cm}$, ensaiando as peças a diferentes condições de carregamento. Os autores observaram que os deslocamentos medidos no revestimento eram devidos em grande parte a rotações ocorridas nas juntas e a fissuras nas peças, tendo a curva elástica do concreto pouca influência. 
Com relação às juntas circunferenciais (entre os anéis) os autores destacam que os pads colocados no contato para regularização da superfície e melhor distribuição das tensões tem grande influência na transferência de esforços entre um anel e outro. A tensão normal atuante nestes pads, que é dada em função da força de avanço longitudinal aplicada pela máquina, tem influência direta nos momentos transmitidos entre as peças por tensões cisalhantes atuantes nos pads.

Em uma comparação entre a modelagem direta das juntas com a metodologia indireta, considerando o revestimento contínuo e redução da rigidez conforme proposto por Muir-Wood (1975), os autores obtiveram boa concordância em alguns resultados (deslocamentos e momentos fletores negativos), entretanto a metodologia indireta subestimou o máximo momento fletor positivo. Os autores responsabilizam esta diferença ao fato de não ser possível levar em conta no método indireto o fato de que algumas juntas são mais influenciadas do que outros por conta do perfil do carregamento aplicado.

Investigando a influência dos parâmetros das juntas no comportamento dos anéis, Do et al. (2013) realizaram análises paramétricas bidimensionais variando o número, distribuição e rigidez das juntas longitudinais. Com relação à quantidade e distribuição das juntas, os resultados obtidos foram semelhantes aos observados por Hefny e Chua (2006), com redução no momento máximo na medida em que a quantidade de juntas aumenta, mesmo levando em conta a rigidez à rotação nas juntas, diferentemente da análise de Hefny e Chua (2006). Avaliando a influência da rigidez à rotação $\left(K_{R O T}\right)$, os autores utilizaram o parâmetro razão da rigidez à rotação, um fator adimensional introduzido por Lee et al. (2001), apresentado na Equação (4.8), que depende das propriedades do concreto dos segmentos (módulo de elasticidade $E$ e inércia $I$ ), com as verificações sendo realizadas por metro de revestimento $(l=1)$. Segundo Lee et al. (2001), a faixa típica de valores de $\lambda$ para túneis em solo é de 0,03 a 0,3.

$\lambda=K_{R O T} \cdot l / E \cdot I$

Para efetuar as análises comparativas, os autores definiram ainda outros adimensionais - a razão do momento fletor, $R_{M}$, e a razão da força normal, $R_{N}$, que representam a razão do máximo valor absoluto destes esforços induzidos no revestimento segmentado em correspondência a um valor induzido em um 
revestimento contínuo. Da mesma maneira foi definida a razão de mudança do diâmetro, $R_{\text {DIAM }}$. Nos gráficos da Figura 4.11 são apresentados os resultados obtidos.

Figura 4.11 - Avaliação da influência da rigidez à rotação das juntas no comportamento do revestimento.
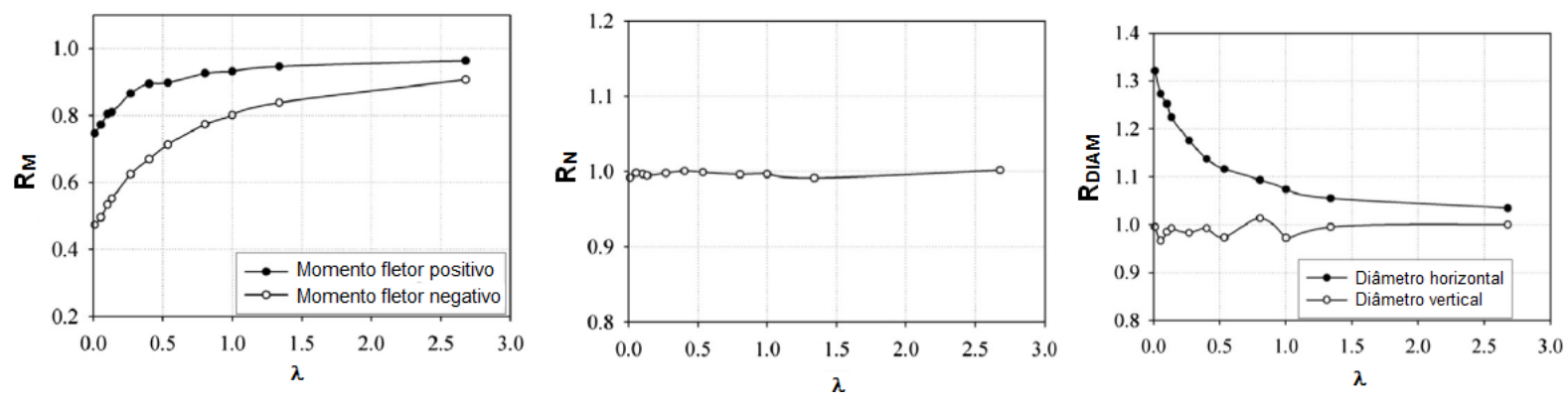

Fonte: adaptado de Do et al. (2013).

As análises foram realizadas para o caso de um túnel com 6 segmentos e sem alteração nos parâmetros geomecânicos do solo (sendo que foram adotados $E_{s}=$ $150 \mathrm{MPa}$ e $k_{0}=0,5$ ). $O$ gráfico da análise da razão $R_{M}$ mostra que o momento fletor atuante é muito sensível à rigidez à rotação adotada. Para valores de $\lambda$ de 0 até 0,5 , faixa de valores aplicáveis a túneis escavados em solo, a variação de $R_{M}$ foi de aproximadamente $30 \%$. Para valores altos de $\lambda$, a razão do momento fletor se aproxima da unidade, pois quanto maior a rigidez da junta, mais próximo é o comportamento do revestimento segmentado ao de um revestimento contínuo. Já a força normal no revestimento não é sensível a variações de $K_{R O T}$.

Com relação aos deslocamentos, verifica-se que os deslocamentos verticais sofreram pouca variação, enquanto que os deslocamentos horizontais para valores baixos de $\lambda$ foram bem superiores aos deslocamentos previstos em um revestimento contínuo. Cabe destacar que um aumento na rigidez à rotação das juntas resulta em um aumento na rigidez do revestimento e por isso em uma redução no deslocamento horizontal do túnel, se aproximando assim do valor calculado para o revestimento contínuo. Os autores verificaram, por fim, que a variação da rigidez axial e radial tem efeito negligenciável no comportamento dos anéis. 


\subsection{ANÁLISES NUMÉRICAS - CAPACIDADES E LIMITAÇÕES}

A aplicação de simulações numéricas para análise de túneis é um padrão atualmente e o uso desta poderosa ferramenta com acurácia requer o conhecimento de suas capacidades e limitações.

Kolymbas (2005) descreve algumas dificuldades inerentes aos procedimentos numéricos, tais como: tratamento de problemas não lineares (decorrentes, por exemplo, de grandes deformações e do comportamento de alguns materiais), que é contornada por meio de métodos de aproximações numéricas; a aproximação por discretização que é realizada em um modelo de elementos finitos, com a solução das equações de deslocamento ou tensão somente em um número finito de nós, com interpolação do resultado entre os pontos; e a falta de unicidade inerente a alguns problemas, que impõe dificuldades aos procedimentos numéricos.

O autor levanta o ponto de que atualmente há diversos códigos de programas disponíveis, entretanto sua qualidade não é comprovada, há algumas incertezas inerentes aos algoritmos numéricos utilizados e os códigos são inacessíveis para apuração. Kolymbas (2005) destaca por fim que os principais pontos de atenção ao realizar uma análise numérica são em relação à escolha das equações constitutivas dos materiais, definição das condições iniciais do problema e definição das condições de contorno.

Potts (2003) apresenta um amplo trabalho destacando as principais capacidade e limitações de análises numéricas. Em seu levantamento a respeito dos pontos favoráveis, o autor destaca:

- as análises numéricas tem capacidade para fazer tudo o que análises convencionais fazem e ainda muito mais;

- fornecem mecanismos de comportamento;

- é possível lidar com problemas simples e complexos.

Já os pontos negativos levantados pelo autor são os seguintes:

- há incertezas nos algoritmos numéricos: os programas utilizam estratégias diferentes para solucionar a não-linearidade, consequentemente a acurácia dos resultados de cada programa é diferente.

- há limitações em alguns modelos constitutivos utilizados: a previsão de alterações de volume sob grandes deformações é um problema recorrente em diversos 
modelos, inclusive no Mohr-Coulomb. Além disso, o autor observa que o formato das superfícies de plastificação, de potencial plástico e de ruptura no plano deviatórico tem um efeito significativo nos resultados, por isso é essencial que o usuário entenda esses efeitos e as considerações feitas no programa em uso;

- os resultados são influenciados pela modelagem do usuário: mesmo em problemas completamente definidos (fornecidos os valores de entrada e modelos constitutivos a se utilizar), a maneira de modelar do usuário tem grande influência nos resultados obtidos. Por isso, é fundamental ter critério e cuidados devidos na manipulação dos dados, na modelagem do problema e na interpretação do resultado.

Martins (2008) destaca algumas ações dos usuários para minimizar alguns erros de modelagem em análises numéricas. Erros devido à aproximação da solução dependem do modelo constitutivo adotado para o material e do esquema da solução numérica. Estes erros podem ser evitados ao se verificar se o modelo constitutivo escolhido é apropriado para o problema em questão, utilizando-se um problema conhecido para verificar os resultados fornecidos pela modelagem. Os erros devido ao cálculo numérico dependem da seleção do grau de precisão requerido e da seleção do tamanho dos incrementos de carga. Este erro pode ser minimizado observando a convergência da solução, realizando análises com tamanho de incremento da carga sucessivamente menor até que não haja melhoria adicional na exatidão da solução. Erros devidos à aproximação do domínio ocorrem quando o domínio não é refinado o bastante. Para minimizar este erro deve-se proceder com o refinamento progressivo da malha. Quando este incremento não resultar em um aumento significativo na exatidão da solução, a malha está adequada.

\subsection{MODELOS CONSTITUTIVOS}

O conhecimento do comportamento do solo é fundamental para o dimensionamento de uma obra geotécnica. A utilização de modelos constitutivos adequados para traduzir a relação tensão-deformação do solo é essencial para uma correta previsão do comportamento deste quando submetido a determinadas solicitações. Alguns pontos são importantes na elaboração de um modelo constitutivo para se conseguir representar adequadamente o complexo comportamento do solo:

- a não linearidade entre os incrementos das deformações e das tensões; 
- a irreversibilidade de uma parcela das deformações;

- as trajetórias de tensões seguidas durante a história do carregamento;

- a variação de volume causada pelas tensões cisalhantes;

- a anisotropia, representando que as mesmas cargas aplicadas em diferentes direções possam provocar diferentes deformações;

Um modelo constitutivo capaz de levar em conta todos estes fatores pode ser extremamente complexo e pode necessitar de parâmetros de entrada de difícil determinação. Por isso, para resolução de problemas práticos de engenharia é comum que se recorra a modelos simplificados, cujos parâmetros de entrada possam ser obtidos com maior facilidade a partir de ensaios de laboratório ou de campo, ficando a aplicação de modelos mais complexos por enquanto restrita à investigação do comportamento do solo em ensaios de laboratório.

O modelo de comportamento mais simples é o elástico linear, que propõe uma relação única entre as tensões e deformações, expressa pela lei de Hooke. Sua capacidade é bastante restrita e não representa bem o comportamento dos solos, havendo então a necessidade de se recorrer outros modelos mais adequados. Modelos elastoplásticos são mais elaborados do que o elástico linear e sua aplicação não é complexa, o que faz com que sejam os mais adotados para representar a escavação de um túnel.

\subsubsection{Modelos elastoplásticos: conceitos básicos}

Diferentemente do modelo elástico linear, os modelos elastoplásticos permitem que ocorram deformações permanentes no solo. $O$ incremento de deformação total originado por uma variação do estado de tensão é composto por uma componente elástica e uma plástica. Um material no regime elastoplástico pode apresentar um dos três comportamentos idealizados mostrados na Figura 4.12.

Um material elastoplástico perfeito tem comportamento elástico até que seja atingida a tensão de plastificação (representada na figura por $\sigma_{y}$ ), a partir da qual o material passa a ter comportamento plástico. Enquanto a tensão $\sigma_{y}$ estiver sendo aplicada, a deformação axial prossegue. Se ocorrer um descarregamento no ponto C, o material volta a apresentar comportamento elástico. $O$ ponto $D$ representa a deformação axial plástica ocorrida. 
Figura 4.12 - Modelos elastoplásticos: a) perfeito; b) com endurecimento; c) com amolecimento.

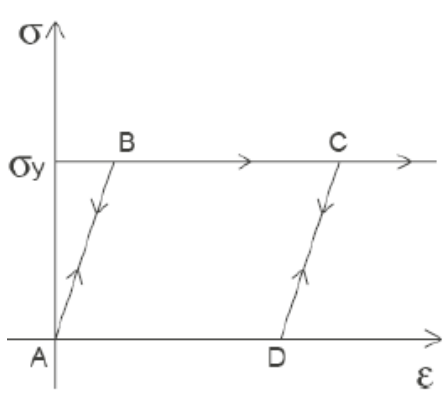

(a)

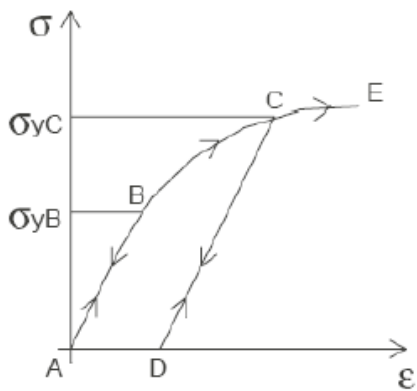

(b)

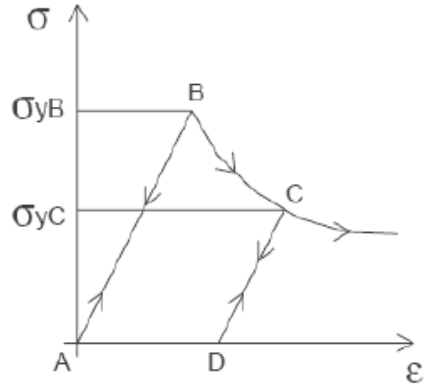

(c)

Materiais elastoplásticos com endurecimento também apresentam um comportamento inicial elástico, até atingir-se a tensão inicial de plastificação $\sigma_{y B}$. Diferentemente do modelo elastoplástico perfeito, se o carregamento prosseguir a tensão aumenta, atingindo o ponto $\sigma_{y C}$, tendo ocorrido deformações elásticas $\mathrm{e}$ plásticas. Se o material for descarregado até o ponto $D$ e na sequência recarregado, terá comportamento elástico linear até o ponto $\mathrm{C}$, até que a nova tensão de plastificação $\sigma_{y c}$ seja atingida. Se o carregamento continuar a ser aumentado, o material volta a apresentar comportamento plástico. Já em materiais elastoplásticos com amolecimento, ocorre o oposto ao caso com endurecimento, ou seja, após o trecho em regime elástico, durante a ocorrência de deformações plásticas, a tensão de plastificação decresce. Materiais com este comportamento requerem atenção especial, pois se a tensão inicial de plastificação é atingida, esta se reduz juntamente com a resistência a solicitações.

Figura 4.13 - Exemplo idealizado do comportamento real de um solo.

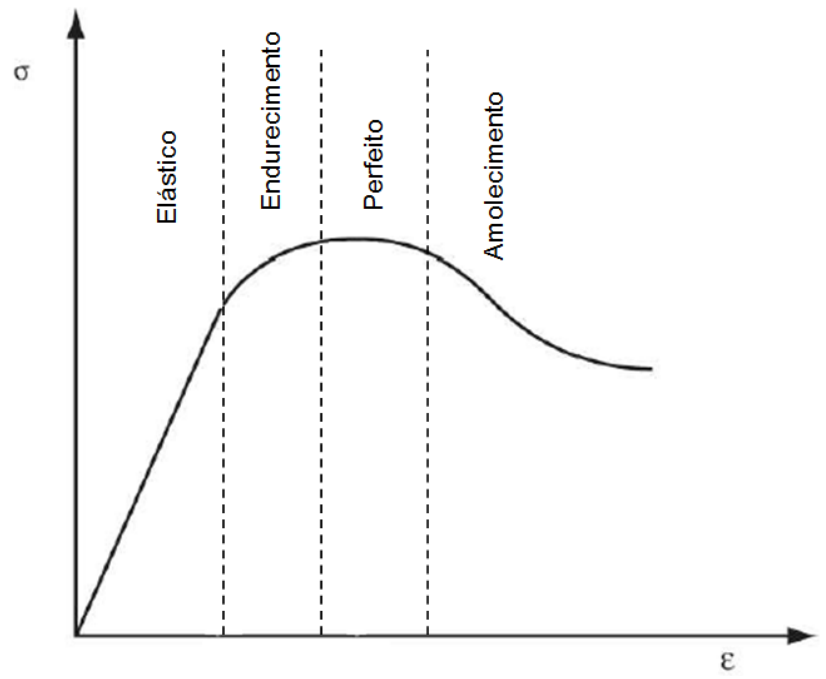

Fonte: adaptado de França (2006). 
O comportamento real de um solo quando carregado se aproxima mais da curva ilustrada na Figura 4.13, onde são observados trechos distintos de comportamento, representando cada um dos modelos apresentados em distintas fases do carregamento. A complexidade deste comportamento não é possível de ser representada pelos modelos elastoplásticos, entretanto verifica-se em geral boa precisão nos resultados fornecidos por estes modelos.

A formulação de um modelo constitutivo elastoplástico requer a definição de alguns princípios básicos: função de plastificação, lei de fluxo e lei de endurecimento ou amolecimento.

A função de plastificação $(F)$ define um limite no qual o material deixa de ter comportamento puramente elástico e passa a ter comportamento plástico. Esta função é definida em termos de componentes de tensão e de parâmetros de endurecimento $(h)$, sendo expressa pela Equação (4.9).

$F\left(\{\sigma\}, h\left\{\varepsilon_{p}\right\}\right)=0$

Valor negativo da função de plastificação representa a região onde ocorrem unicamente deformações elásticas, denominada domínio elástico. Se o seu valor for igual a zero, o estado de tensão atingiu a superfície de plastificação, com o material apresentando a partir deste ponto um comportamento elastoplástico. Valores positivos de $F$ não são possíveis. No espaço geral das tensões, a superfície de nível da função $F$ representa uma superfície de plastificação.

A lei de endurecimento ou amolecimento dá a relação da tensão de plastificação com a deformação plástica, controlando assim a variação da posição da superfície de plastificação durante o escoamento plástico. O parâmetro do endurecimento $h$ depende das deformações plásticas acumuladas e de como é efetuado o carregamento.

A lei de fluxo permite definir a direção e a magnitude dos incrementos da deformação plástica empregando o conceito de potencial plástico e baseando-se no princípio da normalidade, segundo o qual os incrementos da deformação plástica em um ponto de um corpo (submetido a uma variação do estado de tensão) são normais à superfície definida pela função de plastificação. Os incrementos de deformação plástica $\left(\Delta \varepsilon_{i}^{p}\right)$ podem ser expressos como: 
$\Delta \varepsilon_{i}^{p}=\lambda \frac{\partial g}{\partial \sigma_{i}}$

Onde:

- $g$ é a função de potencial plástico, dependente do estado de tensões e que representa uma superfície de potencial plástico no espaço geral das tensões. O vetor normal à superfície de potencial plástico indica a direção da resultante dos incrementos de deformação plástica;

- $\lambda$ é um fator de proporcionalidade, que dá a magnitude do incremento resultante da deformação plástica.

Se a função de potencial plástico coincide com a função de plastificação $(F=g)$, dizse que o fluxo é associado e o caso contrário é denominado de fluxo não-associado. A lei de fluxo é importante para controlar o efeito da dilatância, que tem influência significativa no controle das alterações de volume e resistência dos solos.

Nos materiais com comportamento elastoplástico perfeito, a superfície de plastificação é fixa no espaço geral das tensões e não muda de tamanho ou posição quando ocorrem deformações plásticas. Já em um material elastoplástico com endurecimento, quando ocorrem deformações plásticas o material apresenta variação da superfície de plastificação. Esta variação pode ocorrer de duas maneiras (Figura 4.14): um endurecimento isotrópico, quando a superfície de plastificação aumenta de tamanho; ou endurecimento cinemático, quando a superfície de plastificação não muda de tamanho, mas muda de posição. Modelos mais complexos consideram a associação destes dois modos de endurecimento, com a superfície de plastificação sofrendo translação e expansão uniforme em todos os sentidos.

Figura 4.14 - Endurecimento isotrópico e cinemático.

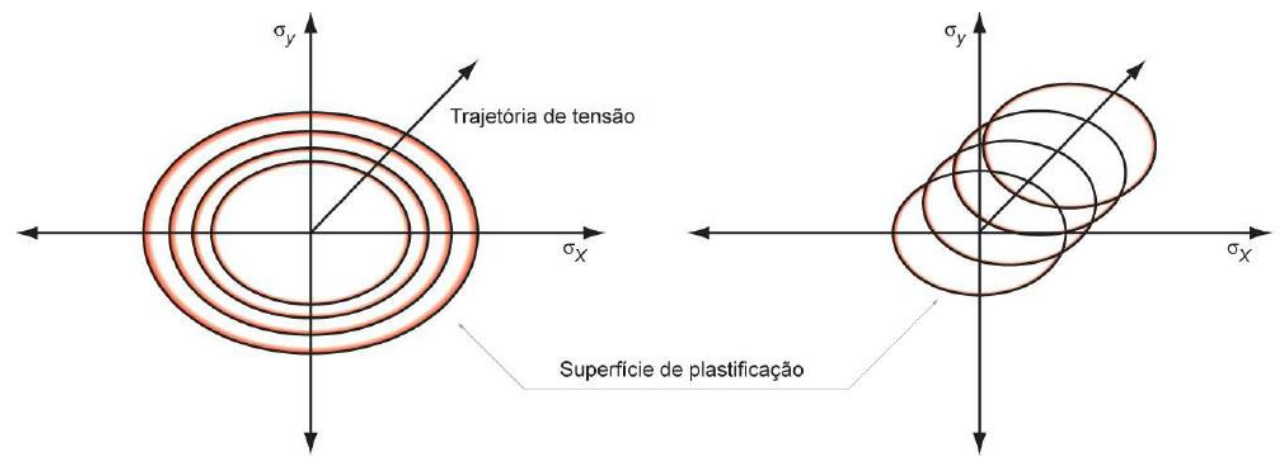

Fonte: França (2006). 
Neste trabalho serão realizadas análises numéricas utilizando dois modelos constitutivos elastoplásticos: o elastoplástico perfeito conhecido como MohrCoulomb e o elastoplástico com endurecimento denominado Hardening Soil. A seguir estes dois modelos serão apresentados com mais detalhes.

\subsubsection{Modelo Mohr-Coulomb}

Conforme destacado por França (2006), a denominação Modelo Mohr-Coulomb é um abuso de linguagem, pois a designação correta seria modelo elastoplástico perfeito cuja superfície de plastificação coincide com o critério de ruptura de MohrCoulomb. Este modelo é um dos mais utilizados nos estudos dos solos devido à sua simplicidade para aplicação, mesmo não representando com fidelidade o comportamento real do solo. De acordo com este modelo, a ruptura é atingida para os estados de tensão em que a maior circunferência de Mohr (Figura 4.15.a) tangencia a envolvente reta de Coulomb (Figura 4.15.b), definida a partir da coesão efetiva $c^{\prime}$ e ângulo de atrito efetivo $\phi^{\prime}$ do solo, parâmetros estes de utilização e significado bem conhecidos. A envoltória é definida pela Equação (4.11) e na Figura 4.15.c é apresentado o critério de resistência de Mohr-Coulomb.

Figura 4.15 - a) Critério de Mohr; b) Critério de Coulomb; c) Critério de resistência de Mohr-Coulomb.

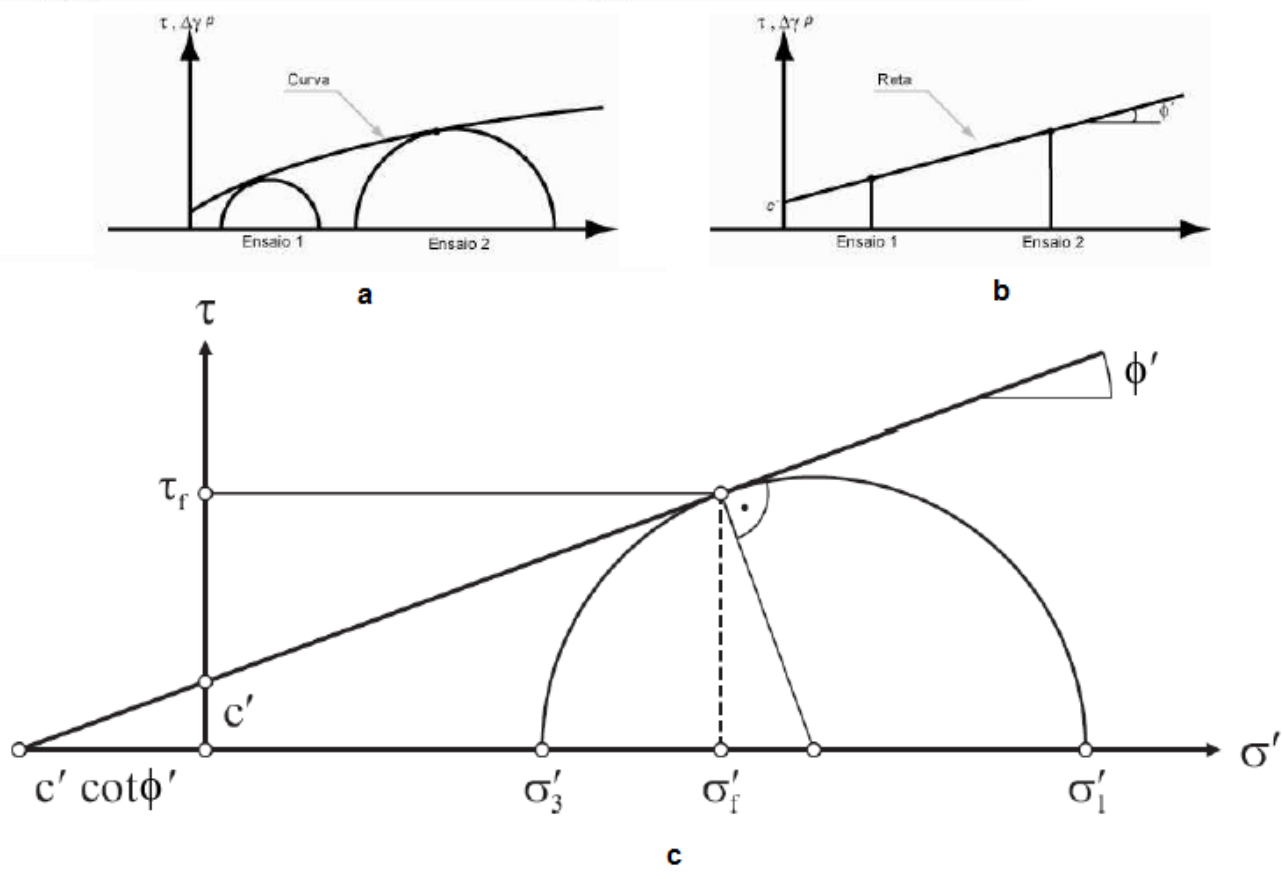

Fonte: adaptado de França (2006). 
$\tau=c^{\prime}+\sigma^{\prime} \cdot \tan \phi^{\prime}$

Sendo $\sigma^{\prime}$ a tensão efetiva normal e $\tau$ a tensão de cisalhamento no plano de ruptura. Reescrevendo a Equação (4.11) em termos de tensões principais, obtêm-se as funções de plastificação, que quando plotadas no espaço das tensões principais definem a superfície da Figura 4.16.

Figura 4.16 - Superfície de plastificação de Mohr-Coulomb para coesão nula.

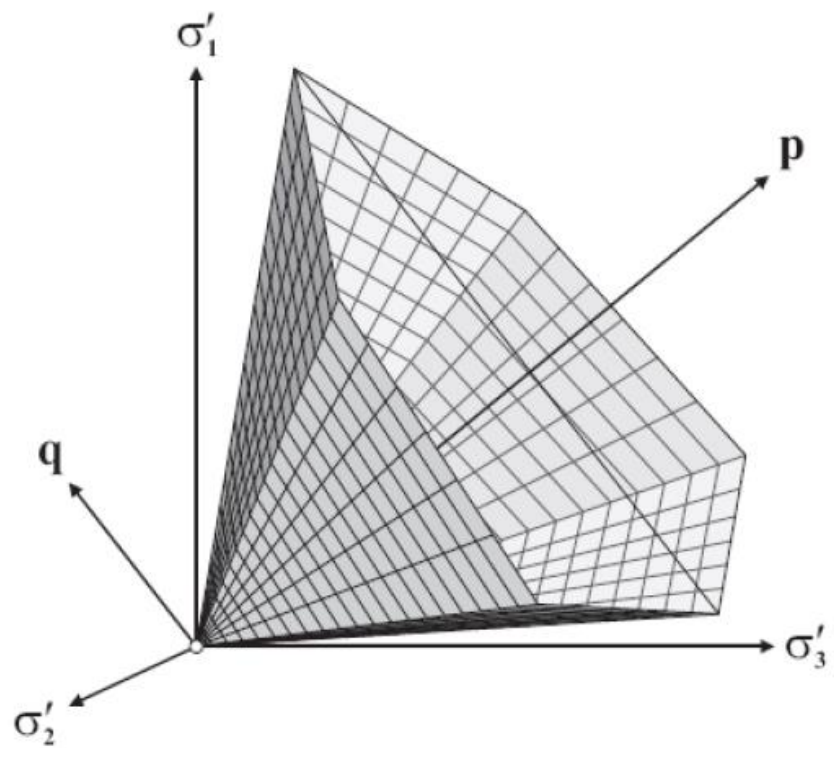

Fonte: PLAXIS (2016).

Um ponto importante a ser abordado na utilização do modelo Mohr-Coulomb é a dilatância, que corresponde à alteração de volume em um material associada a deformações cisalhantes no escoamento plástico. A dilatância é caracterizada pelo ângulo de dilatância $(\psi)$, que corresponde à razão entre deformações volumétricas plásticas e deformações cisalhantes plásticas quando 0 material entra em plastificação e que define também a inclinação da superfície de potencial plástico.

No caso em que a superfície de plastificação coincide com a superfície de potencial plástico, diz-se que o fluxo é associado e nesta condição o ângulo de dilatância é igual ao ângulo de atrito $(\psi=\phi)$. Caso contrário, na lei de fluxo não-associado, $\psi<$ $\phi$. Se o ângulo de dilatância é nulo, não ocorre deformação volumétrica plástica durante o cisalhamento, ocorrendo apenas deformação cisalhante. Ao utilizar o modelo Mohr-Coulomb, não é recomendada a adoção de lei de fluxo associado, pois a superfície de plastificação do modelo superestima a dilatância do material para esta condição. 
A importância da definição do ângulo de dilatância é exemplificada por Vermeer e de Borst (1984). Os autores apresentam resultados de uma simulação numérica de aplicação de uma carga em uma placa circular rígida em um solo não-coesivo. No gráfico de recalque por carregamento mostrado na Figura 4.17, os autores apresentam os resultados para duas situações: considerando fluxo associado e tomando $\psi=0$. Verifica-se que as resistências obtidas em ambas as situações foram semelhantes e próximas à solução analítica indicada no gráfico. Contudo os recalques estimados na condição de fluxo associado foram bem inferiores.

Figura 4.17 - Comparação de resultados de simulação numérica de aplicação de carga em placa circular variando o ângulo de dilatância.

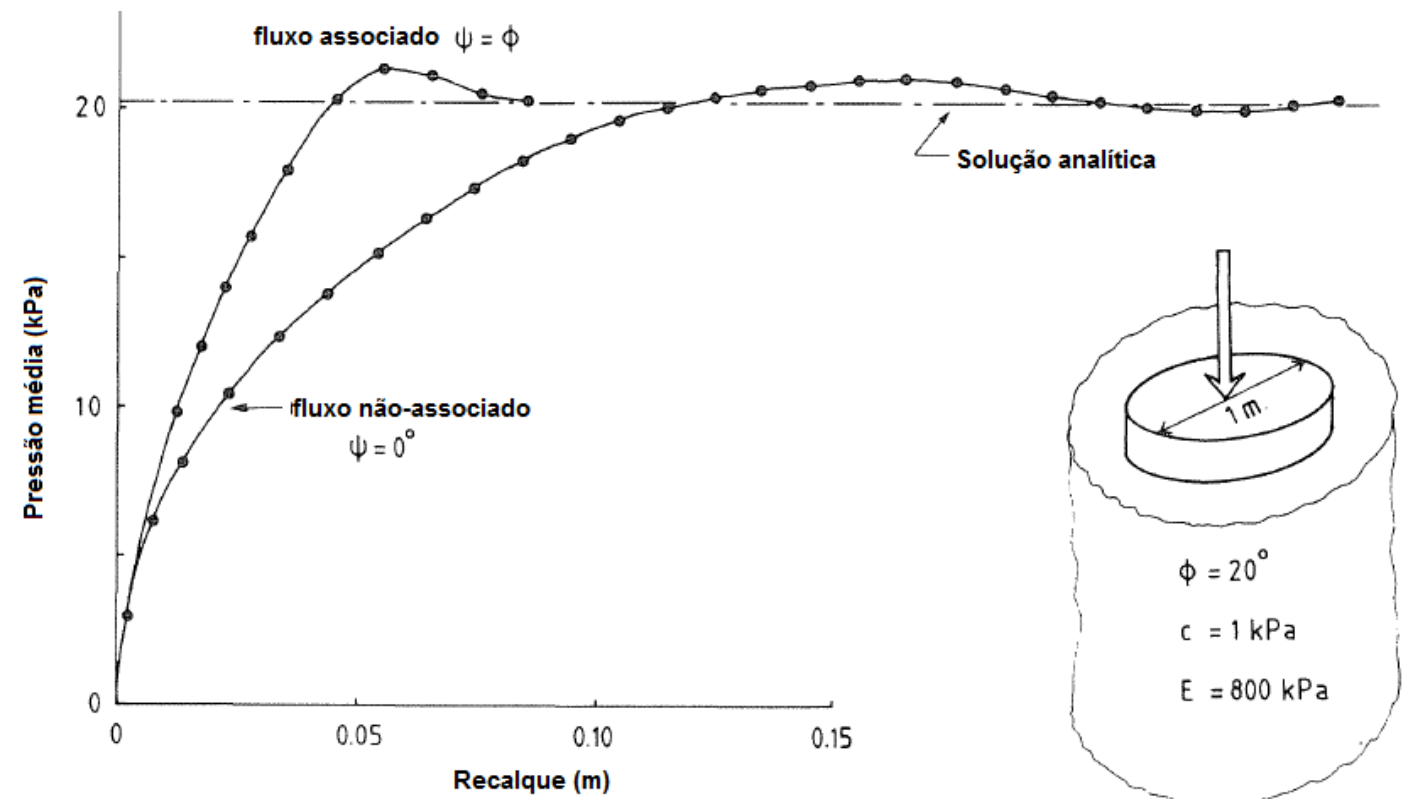

Fonte: adaptado de Vermeer e de Borst (1984).

Vermeer e de Borst (1984) destacam que em solos o ângulo de dilatância é significativamente inferior ao ângulo de atrito e apresentam alguns valores típicos em função do tipo de solo: areia compacta - 15; areia fofa - menos de $10^{\circ}$; argila normalmente adensada $-0^{\circ}$.

No modelo Mohr-Coulomb o comportamento elástico é isotrópico e definido a partir da lei de Hooke generalizada. Pode-se dividir a deformação elástica total em duas parcelas: a deformação cisalhante ou distorção $\left(\varepsilon_{q}\right)$, que indica mudança de forma, e a deformação volumétrica $\left(\varepsilon_{p}\right)$, que fornece a mudança de volume. A deformação volumétrica é dependente somente da variação da tensão média $\left(\Delta p^{\prime}\right)$. Já a deformação cisalhante depende somente da variação da tensão desviadora $(\Delta q)$. 


\subsubsection{Modelo Hardening Soil}

Trata-se de um modelo elastoplástico com endurecimento desenvolvido para implementação no programa Plaxis. Neste modelo, as deformações totais são calculadas utilizando módulos de deformabilidade dependentes do nível de tensão média atuante no material e pode ocorrer a expansão da superfície de plastificação em virtude de deformações plásticas.

Em um ensaio triaxial drenado de compressão axial, o solo, ao ser submetido a um carregamento desviador primário, apresenta uma redução na rigidez e são desenvolvidas deformações plásticas irreversíveis. Este comportamento não linear pode ser modelado por meio de uma relação hiperbólica (Duncan e Chang, 1970) e o modelo Hardening Soil utiliza a reprodução desta curva. A relação hiperbólica entre a tensão desviadora $(q)$ e a deformação axial $\left(\varepsilon_{1}\right)$ é obtida por:

$\varepsilon_{1}=\frac{1}{2 \cdot E_{50}} \cdot \frac{q}{1-\frac{q}{q a}}$, para $q \leq q_{f}$

Onde $q_{f}$ corresponde à tensão desviadora última pelo critério de resistência MohrCoulomb, dada pela Equação (4.13) e $q_{a}$ é a assíntota da hipérbole da resistência ao cisalhamento, obtida pela Equação (4.14) e representada na Figura 4.18a. Assim que $q=q_{f}$, o critério de resistência é satisfeito e ocorre plastificação perfeita. $\mathrm{O}$ parâmetro $R_{f}$ é definido como índice de resistência, que deve ser menor do que 1.0 Plaxis adota um valor padrão de 0,9, assumido como representativo para o comportamento da maioria dos solos.

Figura 4.18 - a. Relação hiperbólica tensão-deformação e obtenção de $E_{50}$ e $E_{u r}$ a partir de ensaio triaxial; b. Obtenção de $E_{\text {oed }}$ no ensaio edométrico.
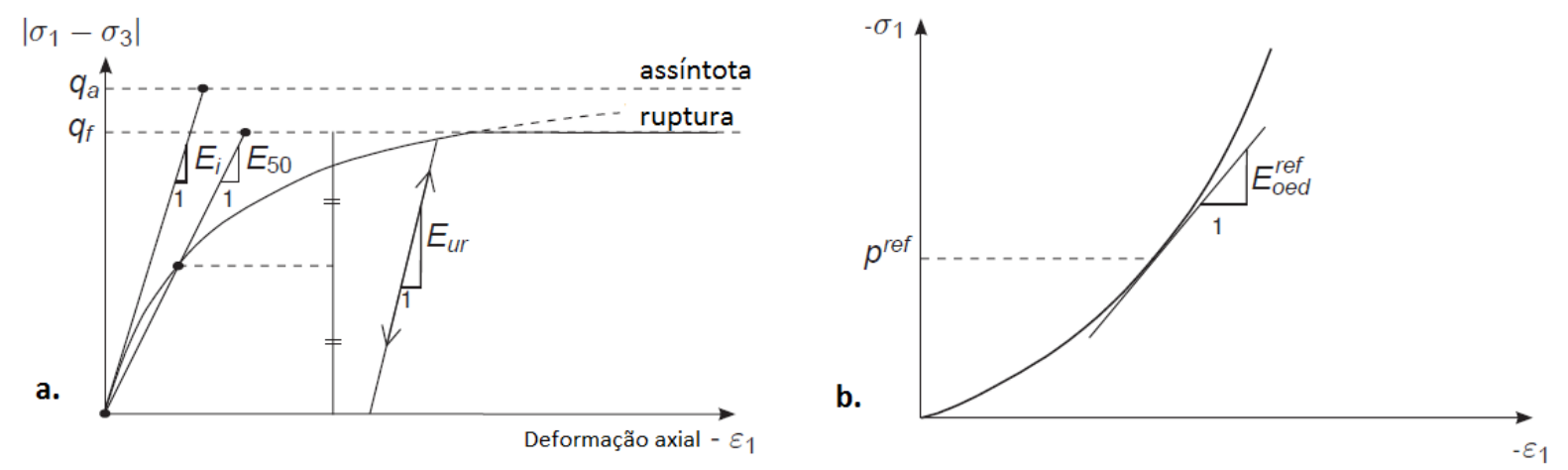

Fonte: PLAXIS (2016) 
$q_{f}=\frac{6 \operatorname{sen} \phi}{3-\operatorname{sen} \phi} \cdot(p+c \cdot \cot \phi)$

$q_{a}=\frac{q_{f}}{R_{f}}$

O parâmetro $E_{50}$ corresponde ao módulo de elasticidade para situação de carregamento desviador primário e depende da tensão de confinamento a que o material está submetido ( $\left.p^{\text {ref }}\right)$ conforme a expressão:

$E_{50}=E_{50}^{r e f} \cdot\left(\frac{c \cdot \cos \varphi-\sigma_{3}^{\prime} \cdot \operatorname{sen} \varphi}{c \cdot \cos \varphi+p^{r e f} \cdot \operatorname{sen} \varphi}\right)^{m}$

Com $E_{50}^{r e f}$ sendo o módulo de deformabilidade de referência, correspondente à pressão de referência $p^{r e f}$. O parâmetro $m$ exprime a relação de dependência entre o módulo $E_{50}$ e a tensão principal menor $\sigma_{3}$ e pode ser obtido em ensaios triaxiais ou oedométricos. Solos duros tendem a apresentar $m \cong 0,5$, em areias $0,5<m<1,0$, enquanto que $m=1$ é típico para argilas normalmente adensadas.

Em contraste com modelos elásticos, no Hardening Soil não há uma relação fixa entre o módulo de elasticidade para carregamento desviador primário $\left(E_{50}\right)$ e módulo de compressão isotrópica primária, $E_{o e d}$,que é definido pela Equação (4.16).

$E_{\text {oed }}=E_{\text {oed }}^{r e f} \cdot\left(\frac{c \cdot \cos \varphi-\sigma_{1}^{\prime} \cdot \operatorname{sen} \varphi}{c \cdot \cos \varphi+p^{r e f} \cdot \operatorname{sen} \varphi}\right)^{m}$

Analogamente, $E_{o e d}^{r e f}$ é o módulo de deformabilidade para situação de compressão isotrópica correspondente à pressão $p^{\text {ref }}$. O módulo $E_{\text {oed }}$ é obtido no ensaio edométrico, conforme indicado na Figura 4.18b, e é utilizado para o controle das deformações volumétricas. Em solos moles, onde é razoável assumir $m=1$, existe uma relação entre $E_{\text {oed }}$ e o parâmetro $\lambda$ do modelo Cam Clay (inclinação da linha de compressão isotrópica no espaço $v-\ln p^{\prime}$ ), dada pelas expressões a seguir, onde $e_{0}$ corresponde ao índice de vazios inicial e $C c$ ao índice de compressão do solo.

$E_{\text {oed }}=\frac{p^{r e f}}{\lambda^{*}}$ 
$\lambda^{*}=\frac{\lambda}{\left(1+e_{0}\right)}$

$\lambda=\frac{C c}{\ln 10}$

O módulo de deformabilidade para descarregamento e recarregamento $E_{u r}$ representa o comportamento exclusivamente elástico para o solo e é dado pela expressão:

$E_{u r}=E_{u r}^{r e f} \cdot\left(\frac{c \cdot \cos \varphi-\sigma_{3}^{\prime} \cdot \operatorname{sen} \varphi}{c \cdot \cos \varphi+p^{r e f} \cdot \operatorname{sen} \varphi}\right)^{m}$

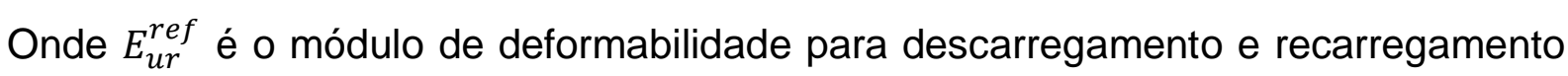
correspondente à pressão $p^{r e f}$. Em muitos casos práticos define-se $E_{u r}^{r e f}$ com sendo o triplo de $E_{50}^{\text {ref }}$. Em situações onde $m=1$, relaciona-se $E_{u r}$ e o parâmetro $\kappa$ do modelo Cam Clay (inclinação da linha de descompressão no espaço $v-\ln p^{\prime}$ ), segundo as expressões a seguir, sendo $\mathrm{Cr}$ o índice de descompressão do solo.

$E_{u r}^{r e f}=\frac{p^{r e f}}{\kappa^{*}}$

$\kappa^{*}=\frac{\kappa}{\left(1+e_{0}\right)}$

$\kappa=\frac{C r}{\ln 10}$

Neste modelo, deformações plásticas podem ocorrer antes mesmo do critério de ruptura Mohr-Coulomb ser atingido. São incorporadas duas superfícies de plastificação, com o endurecimento apresentando duas parcelas: uma devido ao cisalhamento, que é utilizada para modelar as deformações plásticas ocasionadas por solicitações de cisalhamento inéditas (também denominadas carregamento desviador primário) e tem sua forma dependente do coeficiente $m$ e tamanho dependente de $E_{50}$; e outra devido à compressão isotrópica, usada para modelar as deformações plásticas causadas acréscimos de tensões médias, limitando o domínio elástico na direção do eixo das tensões médias, cujo formato da curva é do tipo cap (uma elipse no plano p-q) e cujo tamanho depende de $E_{\text {eod }}$. Na Figura 4.19a são 
representadas as duas superfícies de plastificação, passando de uma condição inicial "0" para a condição "1", com ocorrência de endurecimento e deformações plásticas nas duas superfícies. É ilustrado também na Figura 4.19b o contorno das superfícies no espaço das tensões principais.

A mesma consideração quanto à lei de fluxo feita para o modelo Mohr-Coulomb é adotada no Hardening Soil, com ocorrência de dilatância durante a plastificação quando $\psi>0$. Como é possível ocorrerem deformações volumétricas plásticas devido às solicitações de cisalhamento, o ângulo de dilatância pode assumir um valor entre 0 e $\phi$. Já a superfície de plastificação cap possui um fluxo associado, sendo seu tamanho determinado pela tensão de pré-adensamento.

Figura 4.19 - a) Superfície de plastificação do modelo Hardening Soil no plano p-q; b) contorno total no espaço das tensões principais.

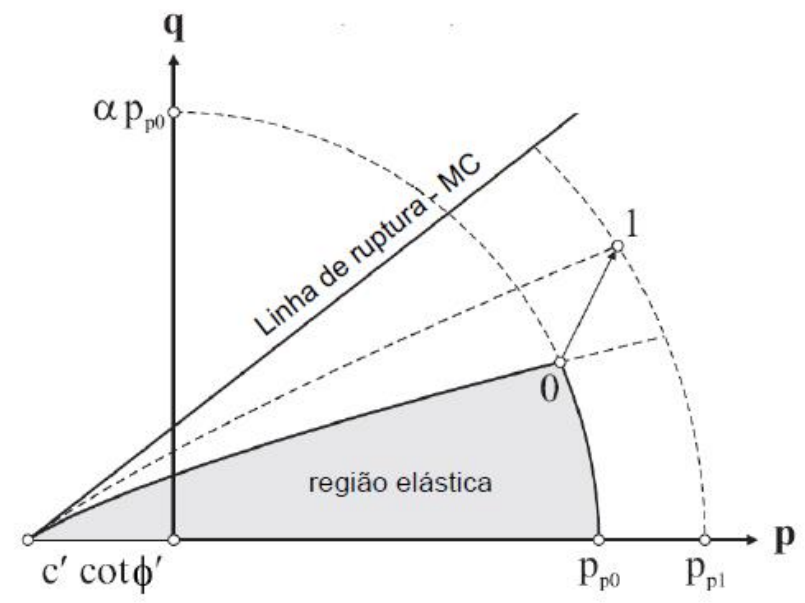

(a)

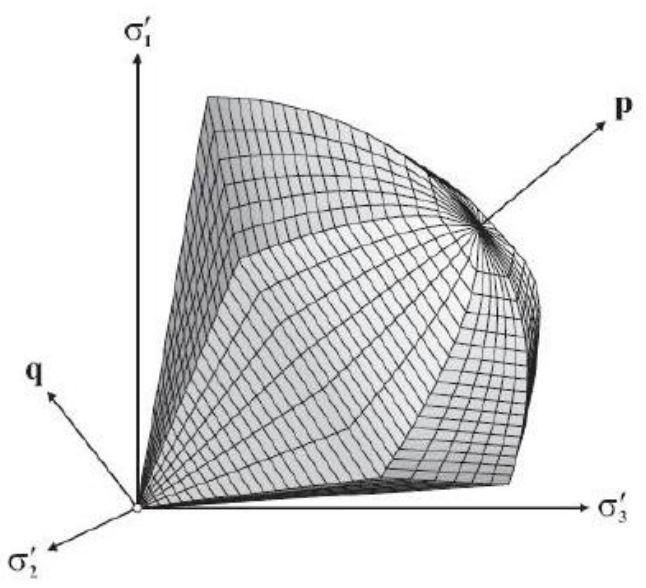

(b)

Fonte: adaptado de PLAXIS (2016).

Em comparação com o modelo Mohr-Coulomb, para a aplicação do modelo Hardening Soil são necessários mais parâmetros de entrada, 10 ao todo. São eles: $c^{\prime}, \phi^{\prime}, \psi, E_{50}, E_{u r}, E_{\text {oed }}, p^{r e f}, m, R_{f}$ e $v_{u r}$. 
5 SIMULAÇÕES NUMÉRICAS E ESTUDO DE CASO 


\section{SIMULAÇÕES NUMÉRICAS E ESTUDO DE CASO}

Neste capítulo serão apresentadas as análises numéricas realizadas aplicando-se alguns dos métodos descritos anteriormente, comparando-os e avaliando-se os resultados. Será reproduzido nos modelos um caso de um túnel executado com máquina tuneladora e os recalques superficiais calculados nos modelos serão comparados com os dados registrados pela instrumentação em campo.

A obra em questão é a da expansão da Linha 5 do Metrô de São Paulo. O trecho entre as estações Adolfo Pinheiro e Eucaliptos (Figura 5.1), aproximadamente $5 \mathrm{~km}$, foi executado por duas tuneladoras paralelas, conforme descrito por Silva et al. (2013). Foram executados túneis com diâmetro de escavação de 6,9 m e diâmetro interno acabado de 6,0 m utilizando-se tuneladoras do tipo EPB. Um perfil geológico esquemático deste trecho é ilustrado na Figura 5.2.

Figura 5.1 - Trecho da expansão da Linha 5 do Metrô de São Paulo escavado por tuneladoras paralelas do tipo EPB.

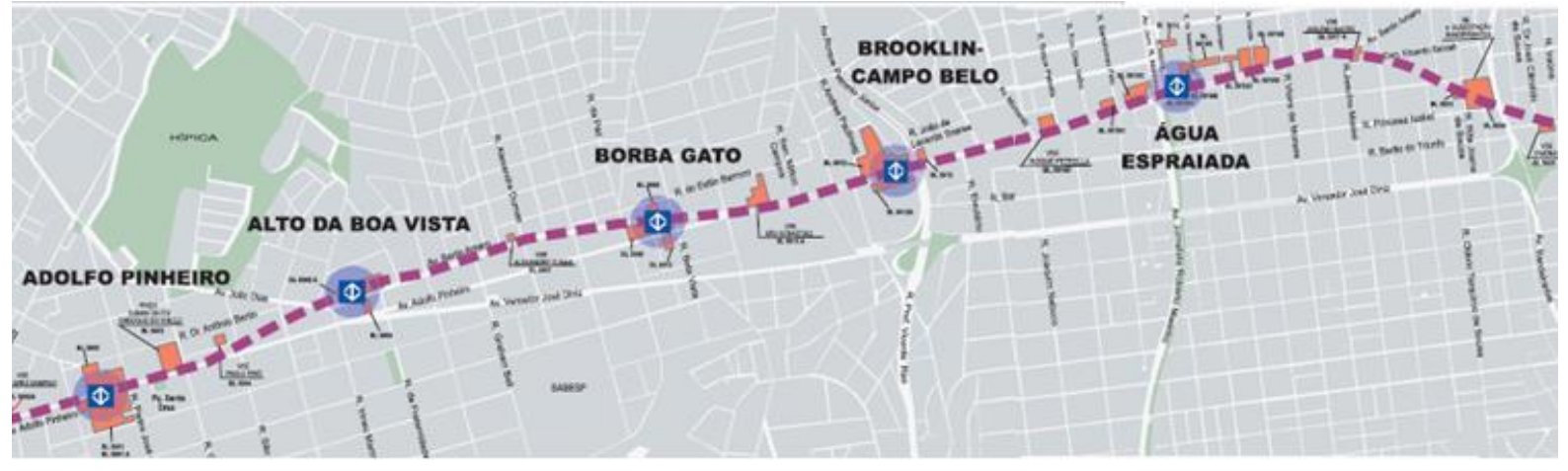

Fonte: Silva et al. (2013).

Figura 5.2 - Perfil geológico esquemático do trecho em questão.

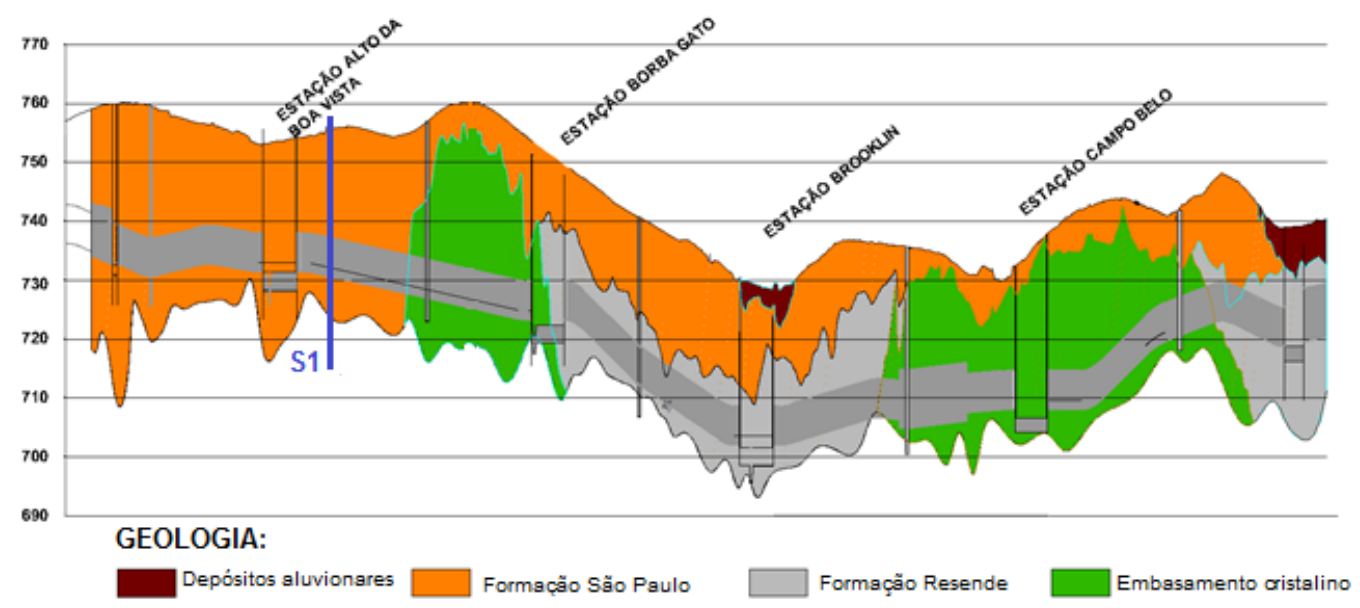

Fonte: Silva et al. (2013). 
A metodologia proposta para o desenvolvimento deste trabalho consiste em uma avaliação comparativa dos resultados de deformações no maciço e esforços no revestimento obtidos em análises utilizando o modelo Hardening Soil variando as seguintes definições:

- método de cálculo, utilizando-se o método de alívio de tensões e o método da contração. Dentre os métodos apresentados no item 4.3, estes dois foram escolhidos pois o primeiro é o método bidimensional mais utilizado em projetos de túnel e o segundo foi desenvolvido especificamente para representar a escavação mecanizada com uso de tuneladora.

- revestimento do túnel modelado como contínuo e com consideração das juntas, adotando-se neste último caso uma rigidez rotacional equivalente destas.

\subsection{DESCRIÇÃO DAS SEÇÕES ANALISADAS}

As análises comparativas foram realizadas em uma seção da obra em questão. A escolha do trecho a ser simulado foi feita com base em alguns critérios: existência de seção de instrumentação completa na superfície (composta por 4 marcos superficiais, sendo um no eixo do túnel e os outros $3 \mathrm{em}$ um dos lados da escavação, para configurar uma bacia de recalques); seção afastada de outras frentes de serviço da Linha 5, para não haver influência de outras obras nos recalques registrados, como, por exemplo, por efeito do rebaixamento do lençol freático; seção geológica sem intercalação de camadas distintas, buscando horizontes geológicos homogêneos; escavação em geologia conhecida, com ensaios para caracterização dos materiais disponíveis; trecho onde sabidamente não houve problema operacional na máquina, como falha no grouteamento, queda da pressão de frente e longe de paradas para intervenções hiperbáricas. A posição da seção analisada está destacada na Figura 5.2, como S1.

A simulação contemplou somente a passagem da primeira tuneladora. O estudo do comportamento do maciço durante a escavação de túneis paralelos constitui uma análise interessante, contudo não é o objeto de estudo deste trabalho.

A seção S1 ocorre em solos da Formação São Paulo da Bacia Sedimentar de São Paulo: uma camada superficial de 9,0 m de argila porosa vermelha mole a média (indicada pelo código A1), com NSPT $<10$, sobreposta a uma camada de areia fina a 
média argilosa (A2, NSPT entre 5 e 20) que se estende até abaixo da base do túnel. Há uma cobertura de 17,5 metros sobre a coroa do túnel (aproximadamente 2,5 D), portanto a escavação ocorre completamente em areia. O nível d'água foi registrado a $10 \mathrm{~m}$ de profundidade. Na Figura 5.3 está representada a seção geológica, o perfil de uma sondagem executada na região, a posição dos dois túneis (o túnel analisado é o TBM-1) e a posição da instrumentação na superfície.

Figura 5.3 - Seção S1: perfil geológico e instrumentação.

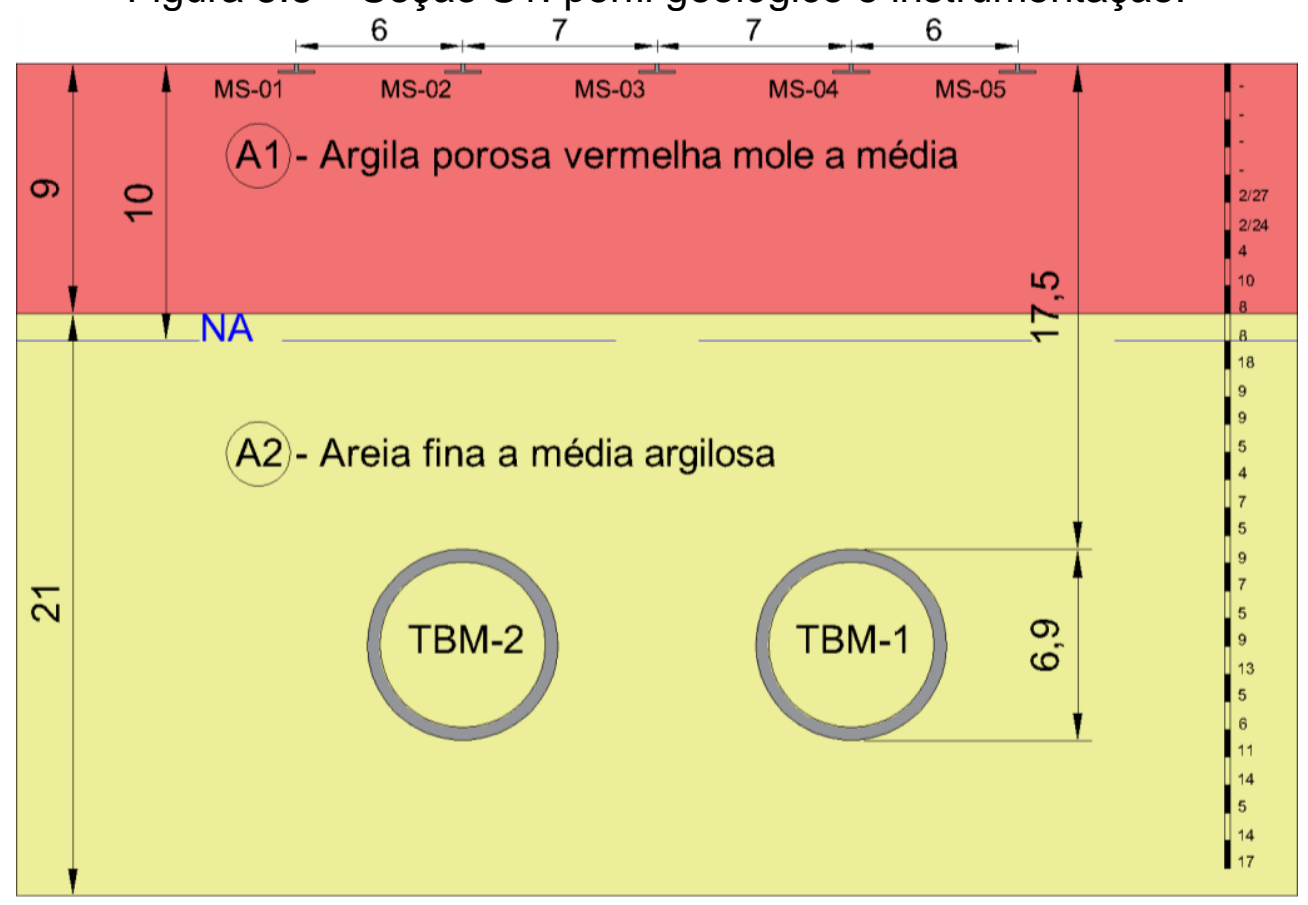

A camada superficial de argila porosa, rica em óxido de ferro, é resultante de processo de laterização. Suas principais características são o aumento da consistência com a profundidade, a colapsividade e a alta porosidade. Abaixo da argila porosa é comum a ocorrência de solos variegados heterogêneos, com intercalação de camadas de areias argilosas e argilas arenosas. A sondagem disponível próxima à região em estudo indicava predominância de areias argilosas na seção e, para efeito de simplificação das análises, esta camada está sendo considerada como homogênea. Por conta das intercalações argilosas, é conferida a esta camada uma coesão superior a areias puras, como será detalhado adiante. Monteiro; Gurgueira e Rocha (2013) fornecem mais informações sobre a geologia de São Paulo, descrevendo com detalhes a formação geológica da região em estudo e indicando aspectos geológicos importantes e serem considerados em um projeto de 
escavação. Massad (2013) apresenta diversos resultados de ensaios e faixas de valores de parâmetros de resistência e deformabilidade para os solos de São Paulo.

$\mathrm{Na}$ Figura 5.4a é mostrada a bacia de recalque superficial registrada pela instrumentação em três momentos: durante a passagem da frente da máquina, na passagem do final do escudo da máquina e após a estabilização dos recalques. A seção de instrumentação dispõe de 4 marcos superficiais, um no eixo da escavação e 3 na lateral, sendo que o mais afastado está distante 20,0 m do eixo. Observa-se que esta distância não foi suficiente para delimitar a bacia de recalques. $O$ recalque superficial longitudinal no eixo da escavação é registrado na Figura 5.4b. É possível observar a influência da aproximação da frente da máquina na seção de instrumentação, com um recalque de aproximadamente $5 \mathrm{~mm}$ (50\% do recalque total) ocorrendo antes da passagem da frente da máquina pela seção. Este alto percentual pode ser um indicativo de pressão de frente aplicada pela máquina insuficiente para evitar deformações no terreno. Na sequência, $25 \%$ do recalque final ocorre durante a passagem do escudo e injeção do anel. Trata-se de um percentual razoável, indicando que não houve falha no grouteamento. Por fim, os $25 \%$ finais do recalque ocorrem à medida que a máquina se afasta da seção, ocorrendo a estabilização a cerca de $40 \mathrm{~m}$ ( 6D) da frente da escavação.

Figura 5.4 - Recalques superficiais transversal e longitudinal na seção S1.
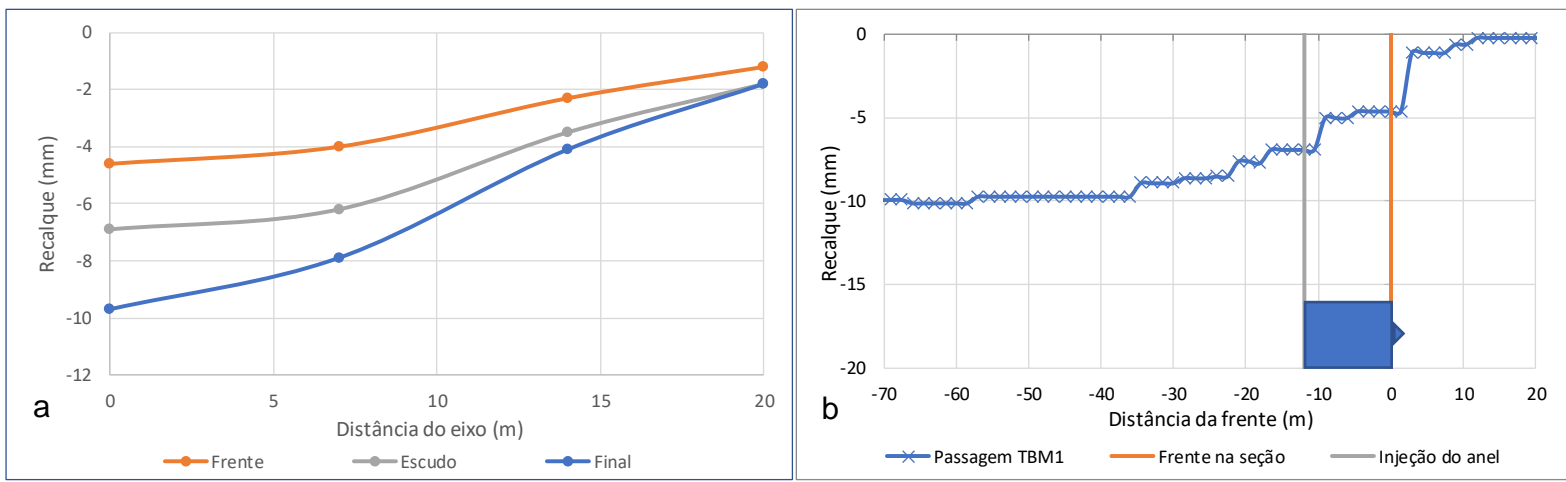

A aproximação das bacias de recalque medidas em campo foi feita utilizando curvas de Gauss e curvas Yield Density. Verificou-se que as duas curvas conseguiram representar bem as bacias reais, conforme ilustrado na Figura 5.6. Na Tabela 5-1 são apresentados os parâmetros utilizados na aproximação pelas curvas Yield Density, além do percentual de perda de solo e a posição do ponto de inflexão da curva de recalque (i) estimado para cada etapa da escavação. Observa-se que a 
perda de solo final foi baixa, o que é comum em escavações mecanizadas. A distância da inflexão da curva de recalque, utilizada para estimar a largura da bacia, está de acordo com a previsão disponível no ábaco mostrado na Figura 5.5 lançando no ábaco os dados obtidos com as leituras de campo, verifica-se que o ponto situa-se no campo do denominado "areia abaixo do nível d'água".

Figura 5.6 - Aproximação das bacias de recalque por curvas de Gauss e Yield Density.

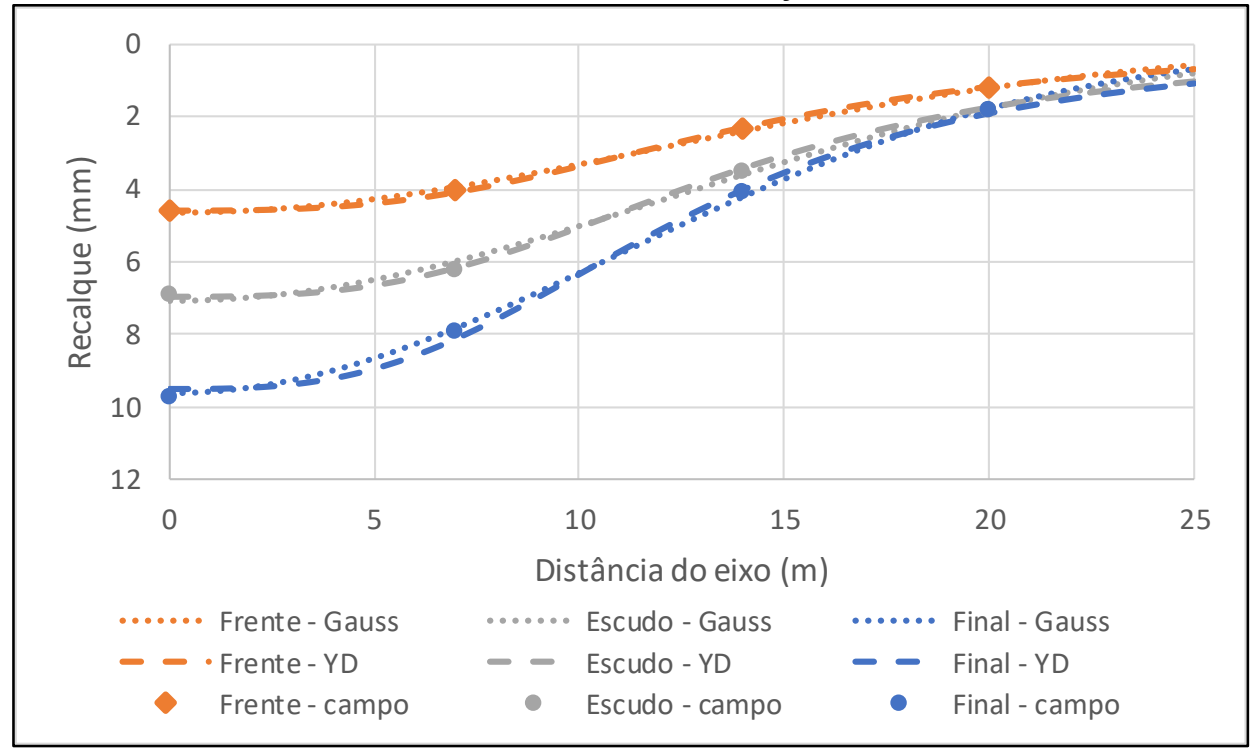

Tabela 5-1 - Parâmetros da curva Yield Density, percentual de perda de solo e distância do ponto de inflexão da curva da bacia de recalques.

\begin{tabular}{rcccc}
\multirow{2}{*}{ Etapa } & \multicolumn{2}{c}{ Parâmetros YD } & \multirow{2}{*}{ Vp (\%) } & \multirow{2}{*}{$\mathrm{i}(\mathrm{m})$} \\
& $\mathrm{a}$ & $\mathrm{b}$ & & \\
\hline Frente & 14 & 3 & 0,37 & 12,1 \\
Escudo & 13,8 & 3 & 0,56 & 12,0 \\
Final & 12,6 & 3 & 0,70 & 10,9 \\
\hline
\end{tabular}

\subsection{DEFINIÇÃO DOS PARÂMETROS GEOLÓGICO-GEOTÉCNICOS}

Conforme mencionado, um dos critérios para escolha da seção a ser analisada foi a existência de ensaios representativos das camadas de solo presentes na seção. A seção S1 é composta por dois horizontes distintos. As informações relativas à argila porosa vermelha mole a média foram obtidas a partir de ensaios de campo e de laboratório realizados pela Companhia do Metropolitano de São Paulo durante os estudos para expansão da Linha 2 na região da Avenida Paulista. Parreira (1991) realizou ensaios de caracterização, ensaios triaxiais e edométrico nas amostras 
extraídas a 3,5 m de profundidade. Com relação aos parâmetros da areia fina e média argilosa, estes foram estimados a partir de ensaios de laboratórios realizados em uma areia com características semelhantes (distribuição granulométrica, índice de vazios inicial, peso específico, $\mathrm{N}_{\mathrm{SPT}}$ ) à areia da região em estudo.

Na Tabela 5-2 constam a caracterização do solo e alguns índices físicos estimados por Parreira (1991) para a camada A1. A partir dos ensaios triaxiais de compressão por carregamento axial, se obtêm os parâmetros de resistência e deformabilidade. $O$ módulo de elasticidade para carregamento desviador primário $\left(E_{50}\right)$ é calculado nas curvas de deformação axial por tensão desviadora obtidas para diferentes tensões confinantes, conforme apresentado anteriormente na Figura 4.18. A coesão e o ângulo de atrito efetivos são obtidos na envoltória de resistência. Considerou-se ângulo de dilatância $(\Psi)$ igual a $0^{\circ}$, por se tratar de uma argila normalmente adensada. A partir dos resultados dos ensaios edométricos, França (2006) realizou uma calibragem dos módulos $E_{\text {oed }}$ e $E_{u r}$ em uma simulação do ensaio em uma análise numérica utilizando o modelo Hardening Soil. Foi realizado um ajuste no módulo edométrico obtido pelo autor, que será esclarecido adiante. O parâmetro $m$ foi adotado como 1, valor usual de argilas. Os parâmetros de resistência e deformabilidade estimados são mostrados na Tabela 5-3. Observa-se que os valores obtidos nos ensaios estão bem próximos dos valores médios para este tipo de solo apresentados por Massad (2013).

Tabela 5-2 - Caracterização e índices físicos da camada A1.

\begin{tabular}{ccccc}
\hline $\begin{array}{c}\text { Areia } \\
(\%)\end{array}$ & $\begin{array}{c}\text { Silte } \\
(\%)\end{array}$ & $\begin{array}{c}\text { Argila } \\
(\%)\end{array}$ & eo & $\gamma\left(\mathrm{kN} / \mathrm{m}^{3}\right)$ \\
\hline 5 & 16 & 79 & 1,62 & 14,7 \\
\hline
\end{tabular}

Fonte: adaptado de Parreira (1991).

Tabela 5-3 - Parâmetros de resistência e deformabilidade da camada A1.

\begin{tabular}{ccccccccc}
\hline $\begin{array}{c}\mathrm{E}_{50} \\
(\mathrm{MPa})\end{array}$ & $\begin{array}{c}\mathrm{E}_{\text {oed }} \\
(\mathrm{MPa})\end{array}$ & $\begin{array}{c}\mathrm{E}_{\text {ur }} \\
(\mathrm{MPa})\end{array}$ & $\mathrm{m}$ & $v$ & $\mathrm{~K}_{0}$ & $\mathrm{c}^{\prime}(\mathrm{kPa})$ & $\phi\left(^{\circ}\right)$ & $\Psi\left({ }^{\circ}\right)$ \\
\hline 4 & 5 & 40 & 1 & 0,2 & 0,6 & 35 & 23 & 0 \\
\hline
\end{tabular}

Fonte: adaptado de França (2006).

$\mathrm{Na}$ camada de areia argilosa, ensaios granulométricos foram realizados em distintas profundidades em amostras de uma sondagem próxima à região em estudo. A caracterização, a faixa de índice de vazios inicial e peso específico do material são apresentados na Tabela 5-4. Os parâmetros de resistência e deformabilidade foram obtidos a partir de resultados de ensaios de laboratórios realizados para outro 
projeto em uma areia com características semelhantes (distribuição granulométrica, índice de vazios inicial, peso específico, NsPT) à areia argilosa da região em estudo.

Tabela 5-4 - Caracterização e índices físicos da camada A2.

\begin{tabular}{ccccc}
\hline $\begin{array}{c}\text { Areia } \\
(\%)\end{array}$ & $\begin{array}{c}\text { Silte } \\
(\%)\end{array}$ & $\begin{array}{c}\text { Argila } \\
(\%)\end{array}$ & eo & $\gamma\left(\mathrm{kN} / \mathrm{m}^{3}\right)$ \\
\hline $42-73$ & $11-29$ & $16-29$ & $0,50-0,58$ & $20,0-20,1$ \\
\hline
\end{tabular}

Foram realizados três ensaios triaxiais CU por compressão axial em corpos de prova adensados isotropicamente sob pressões confinantes distintas: 100, 200 e $400 \mathrm{kPa}$. $\mathrm{Na}$ Figura 5.7 são mostradas as trajetórias de tensões obtidas no plano $s^{\prime} \times t^{\prime}$. A partir deste gráfico, calcula-se a coesão efetiva e o ângulo de atrito do solo ensaiado. No gráfico, a legenda "sigh" indica a tensão confinante aplicada ( $\sigma h)$.

Figura 5.7 - Trajetória de tensões efetivas.

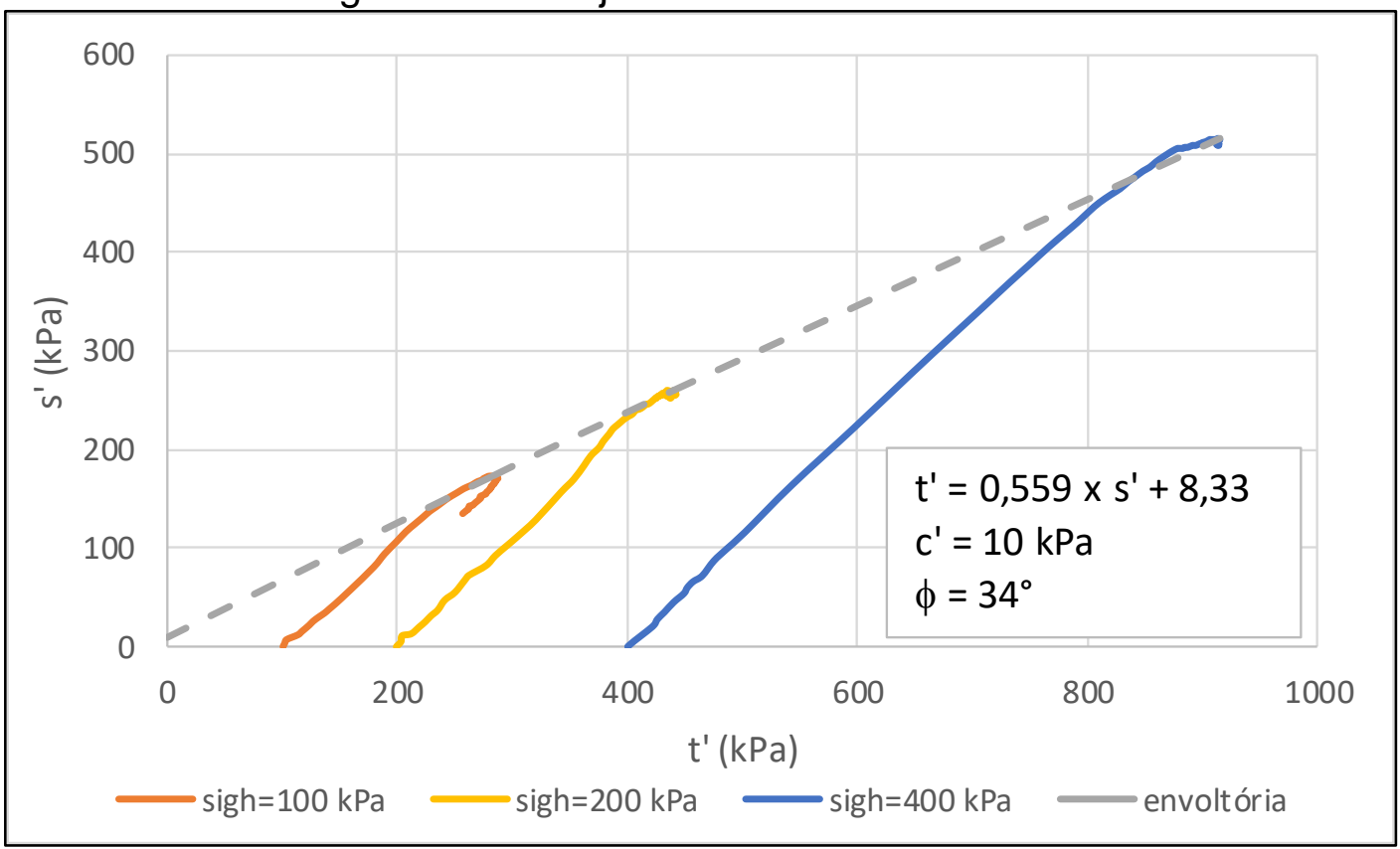

As relações entre a tensão desviadora $\left(q=\sigma_{v}-\sigma_{h}\right)$ e a deformação axial $\left(\varepsilon_{a}\right)$ dos três ensaios são apresentadas na Figura 5.8, onde estão destacados os módulos de elasticidade secantes obtidos a $50 \%$ da tensão desviadora de ruptura $\left(E_{50}\right)$ de cada ensaio. Verificam-se em todas as curvas patamares de ruptura, sem indicativo de resistência de pico. Com relação à determinação do módulo $E_{50}$, pode-se observar um dado curioso: o módulo estimado no ensaio com pressão confinante de $200 \mathrm{kPa}$ foi superior ao ensaio com pressão confinante de $400 \mathrm{kPa}$, pois o corpo de prova em que foi aplicado confinante de $200 \mathrm{kPa}$, ao contrário do esperado, apresentou menor deformação no início do ensaio do que o corpo de prova com confinante de $400 \mathrm{kPa}$. 
Figura 5.8 - Gráfico da tensão desviadora pela deformação axial com determinação de $E_{50}$ em função da tensão de confinamento.

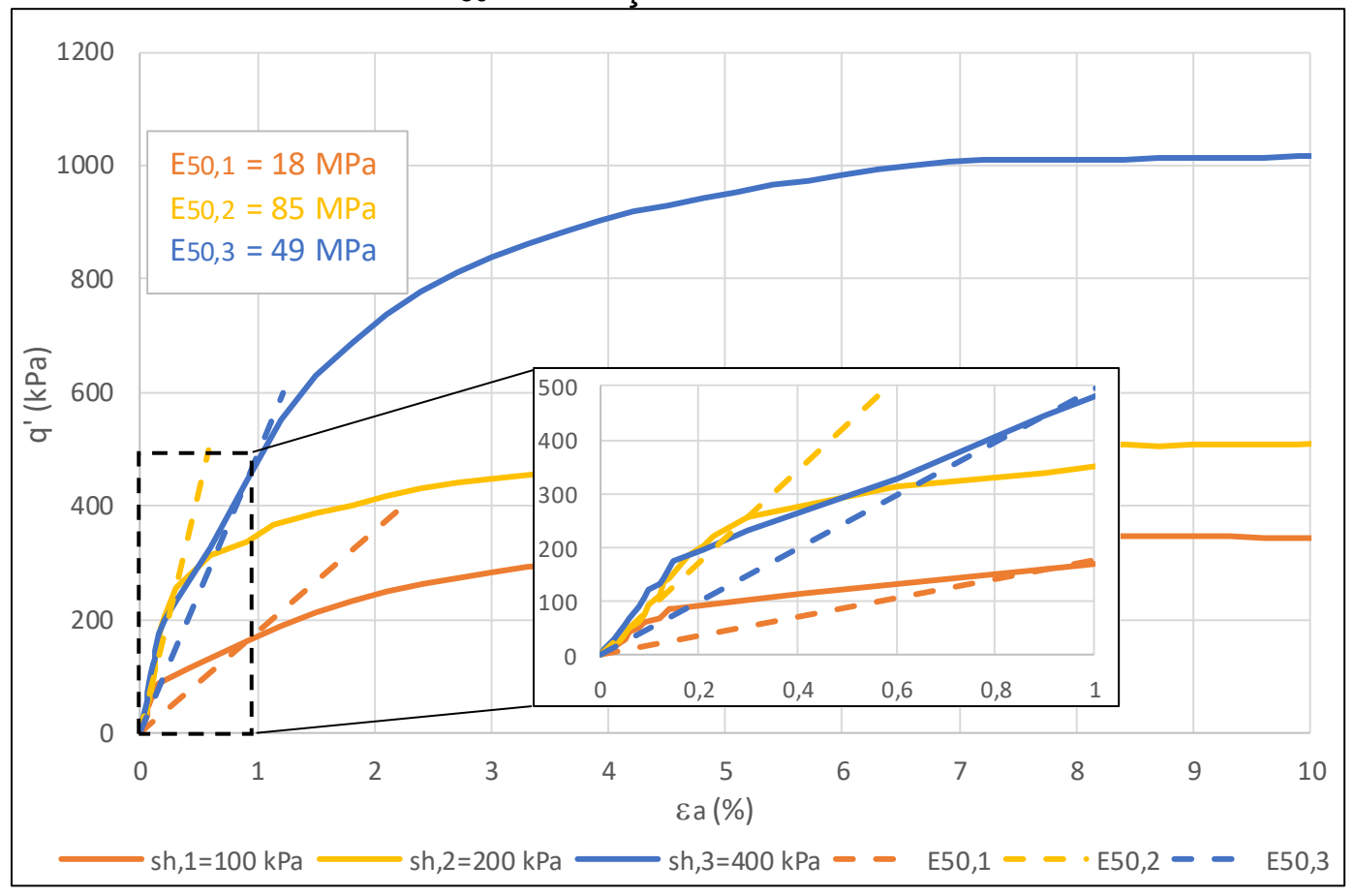

Nos gráficos da Figura 5.9 são apresentadas as relações entre o módulo de elasticidade com as deformações medidas e os módulos $E_{50}$ e $E_{i}$ (módulo de elasticidade tangente inicial, medido sob deformação de 0,05\%) com as tensões de confinamento. No geral, verificam-se módulos mais altos em menores deformações e crescentes com o aumento da tensão de confinamento. É possível observar o comportamento atípico destacado anteriormente do ensaio com tensão confinante de $200 \mathrm{kPa}$, sendo o módulo de elasticidade neste corpo de prova superior ao módulo com calculado no ensaio com tensão confinante de $400 \mathrm{kPa}$ no início do ensaio e a $50 \%$ da tensão desviadora de ruptura.

Utilizando os resultados de $\mathrm{E}_{50}$ determinados nos ensaios com tensões confinantes de 100 e $400 \mathrm{kPa}$, foi calculado o parâmetro $m$ do modelo Hardening Soil, obtido a partir da Equação (4.15). Obteve-se $m=0,8$. Este valor não está compatível com o $E_{50}$ estimado no ensaio com tensão confinante de $200 \mathrm{kPa}$. Contudo, o resultado deste ensaio foi atípico e por isso não está sendo considerado para a estimativa do parâmetro $m$. No gráfico da Figura 5.9b, é mostrada a curva da variação do módulo $E_{50}$ em função da tensão confinante para $m$ valendo 0,8 e pressão de referência $\left(p_{\text {reft }}\right)$ de $100 \mathrm{kPa}$. 
Figura 5.9 - Variação do módulo de elasticidade em função da deformação medida e da pressão confinante.

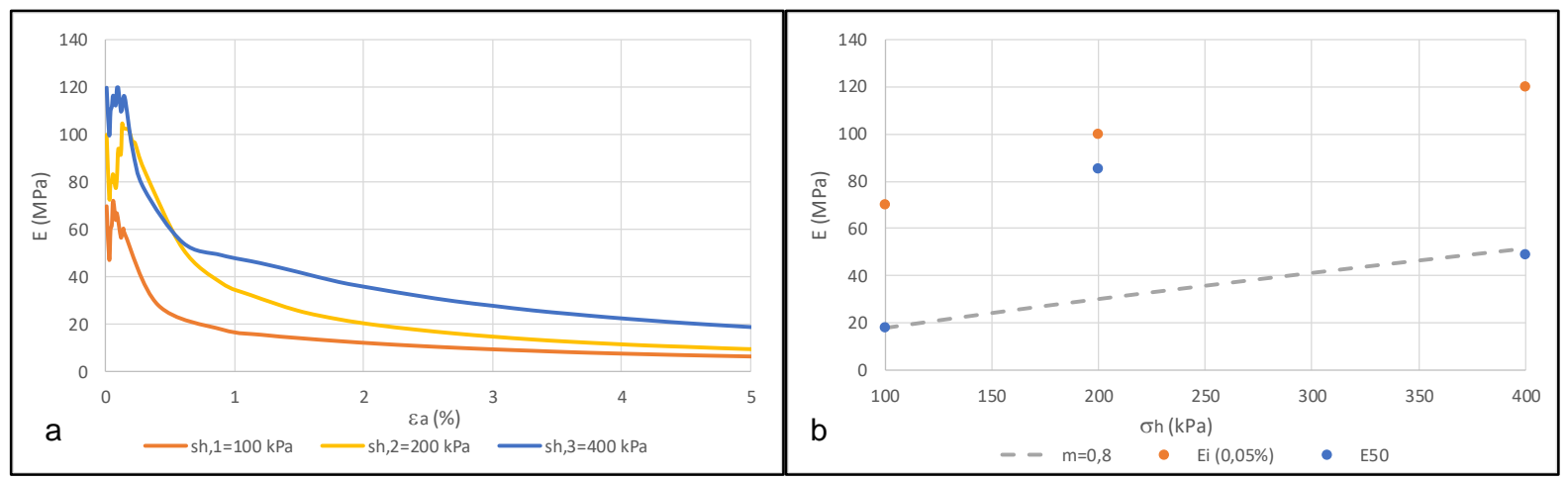

Com relação ao módulo a ser adotado no modelo Mohr-Coulomb, o programa Plaxis permite prever um incremento linear no módulo de elasticidade adotado em função da profundidade. Ou seja, é possível prever um aumento linear no módulo com o aumento da tensão confinante. Analisando os resultados dos ensaios com confinante de 100 e $400 \mathrm{kPa}$, verifica-se um incremento de aproximadamente 100 $\mathrm{kPa}$ no módulo $\mathrm{E}_{50}$ por kPa de incremento na tensão confinante.

Foi realizado um ensaio edométrico aplicando-se tensão vertical de até $1280 \mathrm{kPa}$ na amostra, com sucessivo descarregamento. Na Figura 5.10 são apresentados os gráficos da variação do índice de vazios em função da tensão aplicada e da tensão por deformação vertical. A partir deste último gráfico, pode-se obter os módulos edométrico e de descarregamento, que variam em função da pressão aplicada, conforme indicado nos gráficos da Figura 5.11.

Figura 5.10 - Resultado do ensaio edométrico e indicação da obtenção dos módulos Eoed e Eur.
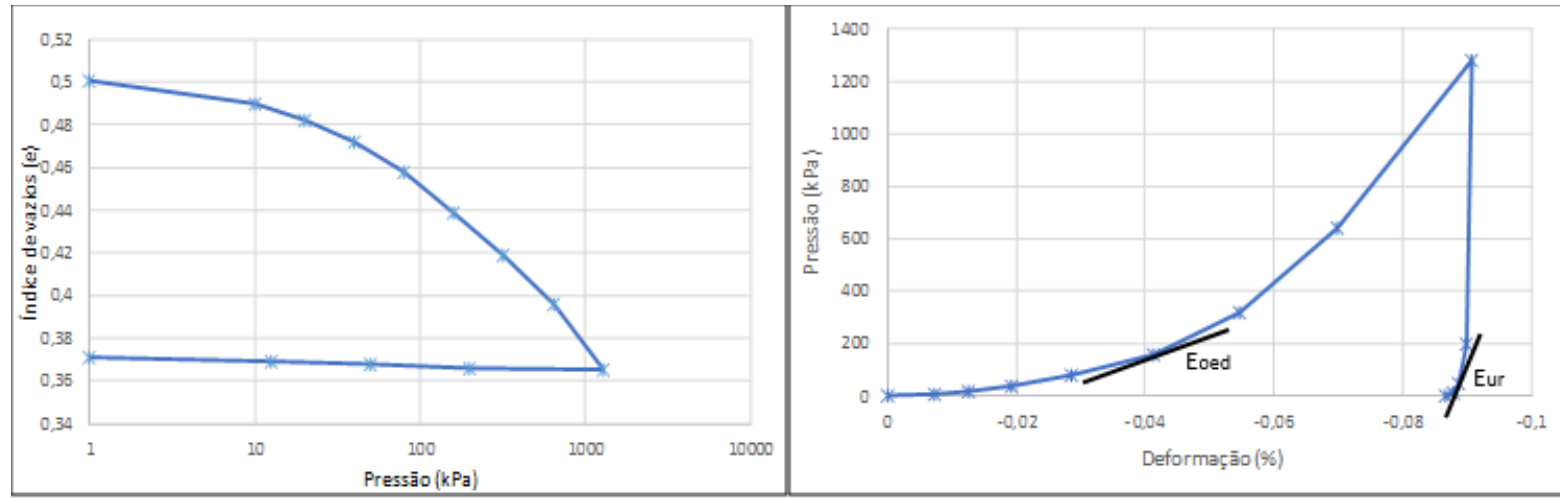
Figura 5.11 - Variação do módulo edométrico e do módulo de descarregamento em função da pressão aplicada.

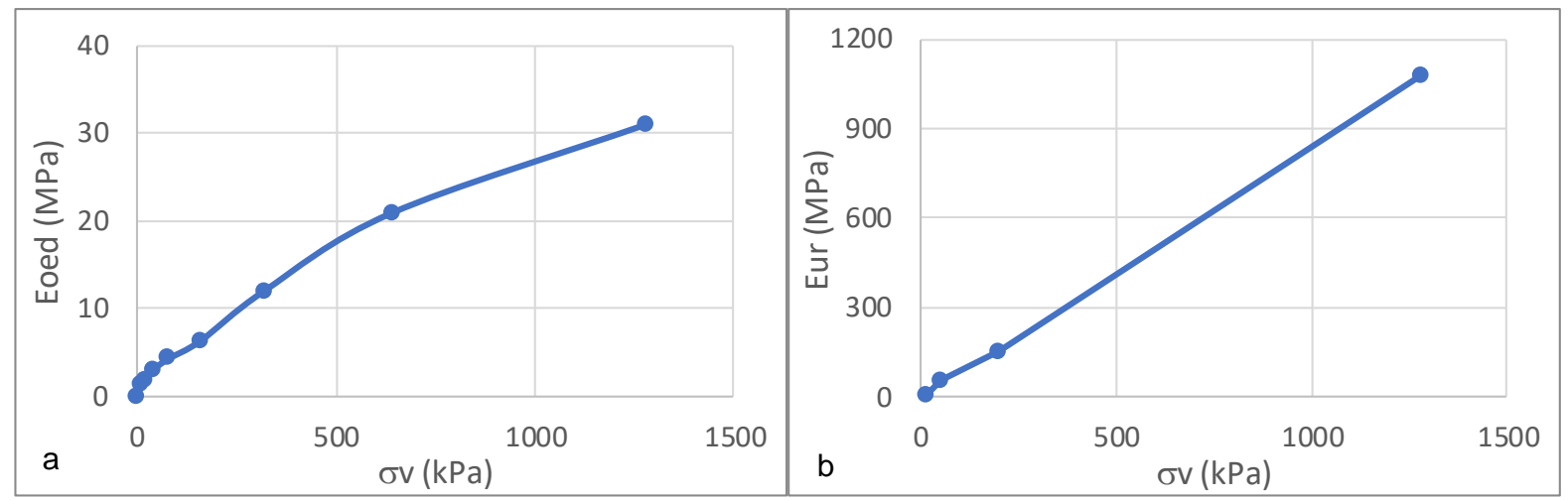

No gráfico da Figura 5.11a, verifica-se que o módulo edométrico para uma tensão vertical de $100 \mathrm{kPa}$ é cerca de $6 \mathrm{MPa}$. Trata-se de um valor inusitado, pois o módulo edométrico deve ser maior do que o módulo de elasticidade, que foi calculado em 18 MPa para a pressão de referência de $100 \mathrm{kPa}$. Por isso, o valor obtido no ensaio será descartado e será adotado o módulo edométrico obtido a partir da Equação (5.1), proveniente da lei de Hooke, que resultou em $22 \mathrm{MPa}$.

$E_{\text {oed }}=\frac{(1-v) \cdot E}{(1-2 v) \cdot(1+v)}$

Já o módulo de descarregamento ( $E_{u r}$ ) calculado na tensão vertical de $100 \mathrm{kPa}$ foi aproximadamente $110 \mathrm{MPa}$, ou seja, cerca de 6 vezes superior ao módulo $\mathrm{E}_{50}$. O parâmetro obtido no ensaio foi mantido, pois observou-se baixíssima recuperação das deformações no descarregamento. Foi calculado um valor de 0,85 para o parâmetro $m$, valor próximo ao calculado com os resultados dos ensaios triaxiais.

Como observado nos ensaios, há uma grande variação nos valores estimados para os módulos de elasticidade em função do tipo de ensaio realizados, da tensão aplicada no corpo de prova e da deformação ocorrida. O modelo elastoplástico perfeito (Mohr-Coulomb) não consegue representar esta variação, já que há somente um módulo de elasticidade como parâmetro de entrada que deve satisfazer todos os tipos de solicitações, sob diferentes níveis de tensão e deformação. Já o modelo Hardening Soil permite trabalhar com 3 módulos distintos ( $E_{50}$, $E_{\text {oed e }} E_{u r}$ ), que são ajustados pelo modelo em função da tensão atuante - o parâmetro $m$ exprime a relação de dependência entre o módulo de elasticidade na pressão de referência $p_{\text {ref }}$ e a tensão atuante. 
Os ensaios de laboratório foram reproduzidos em um programa de elementos finitos impondo as trajetórias de tensões dos ensaios realizados. Foram adotados parâmetros de referência para os dois modelos - os parâmetros obtidos no ensaio triaxial de compressão com tensão de confinamento de $100 \mathrm{kPa}$ e no ensaio edométrico para tensão vertical de referência de $100 \mathrm{kPa}$, apresentados na Tabela 5-5. Foram assumidos os valores de $k_{0}$ e $v$, que são valores típicos para o tipo de solo em estudo. Foi feito um estudo paramétrico variando somente o coeficiente de Poisson nas curvas que reproduziam os resultados dos ensaios e verificou-se que o valor de 0,25 forneceu curvas mais próximas às obtidas nos ensaios. O ângulo de dilatância foi adotado como $0^{\circ}$ por se tratar de uma areia com considerável porção de argila. Além disso, os ensaios triaxiais de compressão não indicaram resistência de pico, o que seria verificado em areias dilatantes.

Tabela 5-5 - Parâmetros de resistência e deformabilidade da camada A2.

\begin{tabular}{|c|c|c|c|}
\hline Modelo & $\begin{array}{l}\text { Hardening } \\
\text { Soil }\end{array}$ & $\begin{array}{c}\text { Mohr } \\
\text { Coulomb }\end{array}$ & Origem \\
\hline $\mathrm{E}_{50}(\mathrm{MPa})$ & 18 & 18 & Triaxial por compressão com $\sigma \mathrm{h}=100 \mathrm{kPa}$ \\
\hline$E_{\text {oed }}(\mathrm{MPa})$ & 22 & - & Lei de Hooke - Equação (5.1) \\
\hline Eur $(\mathrm{MPa})$ & 110 & - & Ensaio edométrico \\
\hline$E_{\text {inc }}(\mathrm{kPa} / \mathrm{kPa})$ & - & 100 & Triaxiais por compressão \\
\hline$v$ & 0,25 & 0,25 & Assumido, verificado por estudos paramétricos \\
\hline ko & 0,7 & 0,7 & Assumido \\
\hline $\mathrm{c}^{\prime}(\mathrm{kPa})$ & 10 & 10 & Triaxiais por compressão \\
\hline$\phi\left(^{\circ}\right)$ & 34 & 34 & Triaxiais por compressão \\
\hline$\Psi\left({ }^{\circ}\right)$ & 0 & 0 & Assumido \\
\hline M & 0,8 & - & Triaxiais por compressão \\
\hline Pref $(\mathrm{kPa})$ & 100 & - & Adotado \\
\hline
\end{tabular}

Em solos da bacia de São Paulo é esperado um pré-adensamento leve a alto. Como o solo em estudo é uma areia fofa a média, com número de golpes no ensaio SPT entre 4 e 18, e os ensaios triaxiais de compressão axial não apontaram resistência de pico, foi assumida para esta análise razão de sobreadensamento unitária. Além disso, a tensão de pré-adensamento define a posição inicial da superfície de plastificação no modelo para todos os pontos da análise. Ao se adotar uma razão de sobreadensamento unitária, qualquer aumento da tensão média atuante causa deformações plásticas. Se valores maiores de sobreadensamento fossem adotados, possivelmente muitos pontos da análise se manteriam dentro do domínio elástico, limitando o potencial do uso de um modelo mais elaborado. 
Nas Figuras 5.12 a 5.14 são apresentadas as simulações dos três ensaios triaxiais por compressão axial realizados. Em um problema de escavação real, não são esperadas deformações de grande magnitude, portanto está destacado o trecho do gráfico até a deformação de $2 \%$. O comportamento das curvas simuladas além desta deformação não é de interesse neste estudo.

Figura 5.12 - Reprodução do ensaio triaxial por compressão axial $-\sigma_{\mathrm{h}}=100 \mathrm{kPa}$.

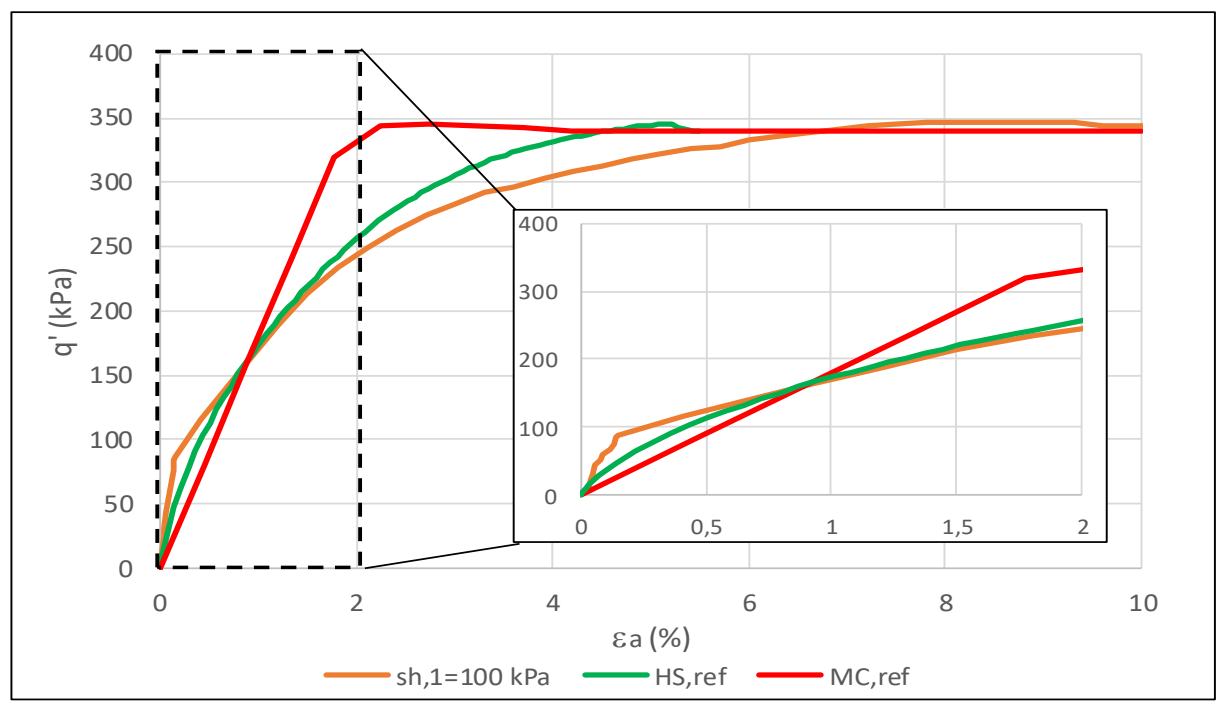

Figura 5.13 - Reprodução do ensaio triaxial por compressão axial $-\sigma_{\mathrm{h}}=200 \mathrm{kPa}$.

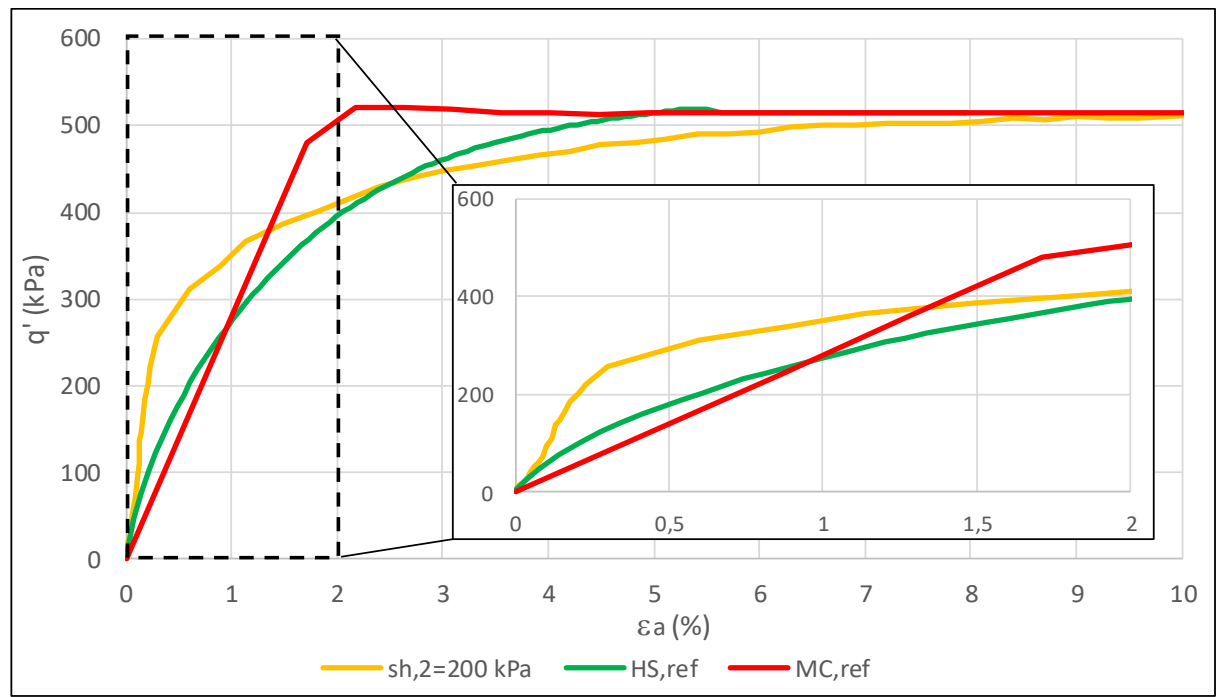

Nas simulações utilizando o modelo Hardening Soil, as curvas obtidas com os parâmetros de referência representam com boa precisão os resultados dos ensaios, com exceção do ensaio com tensão confinante de $200 \mathrm{kPa}$, que, conforme mencionado anteriormente, havia apresentado um comportamento inicial mais rígido do que o usual. Já nas simulações com o modelo Mohr-Coulomb, a aproximação 
bilinear proporcionada pelo modelo não representa bem o formato da curva medida e a curva obtida se afasta consideravelmente da curva medida em determinados intervalos de deformação.

Figura $5.14-$ Reprodução do ensaio triaxial por compressão axial $-\sigma \mathrm{h}=400 \mathrm{kPa}$.

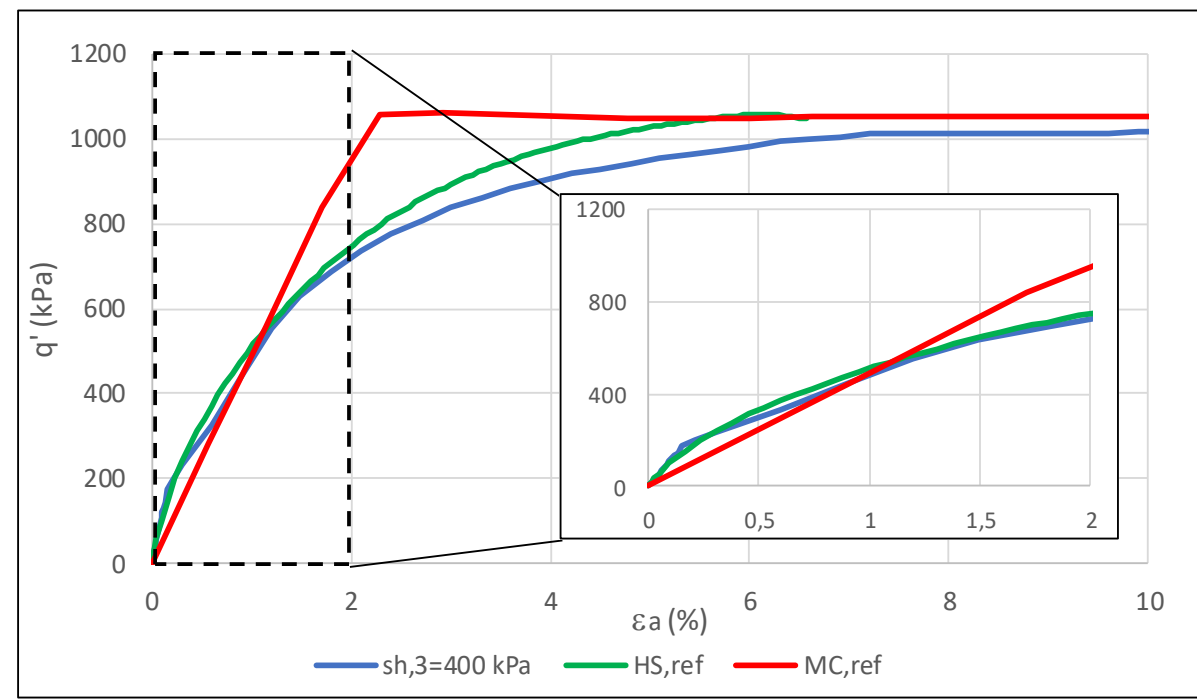

$\mathrm{Na}$ Figura 5.15 são mostrados os resultados da simulação do ensaio edométrico utilizando os parâmetros de referência com os dois modelos constitutivos. Nesta simulação, verifica-se uma grande limitação do modelo Mohr-Coulomb, que não consegue representar a curva de descarregamento, estando as curvas de carregamento e descarregamento sobrepostas. A curva obtida com o modelo Hardening Soil conseguiu representar bem o formato da curva do ensaio.

Figura 5.15 - Reprodução do ensaio edométrico.

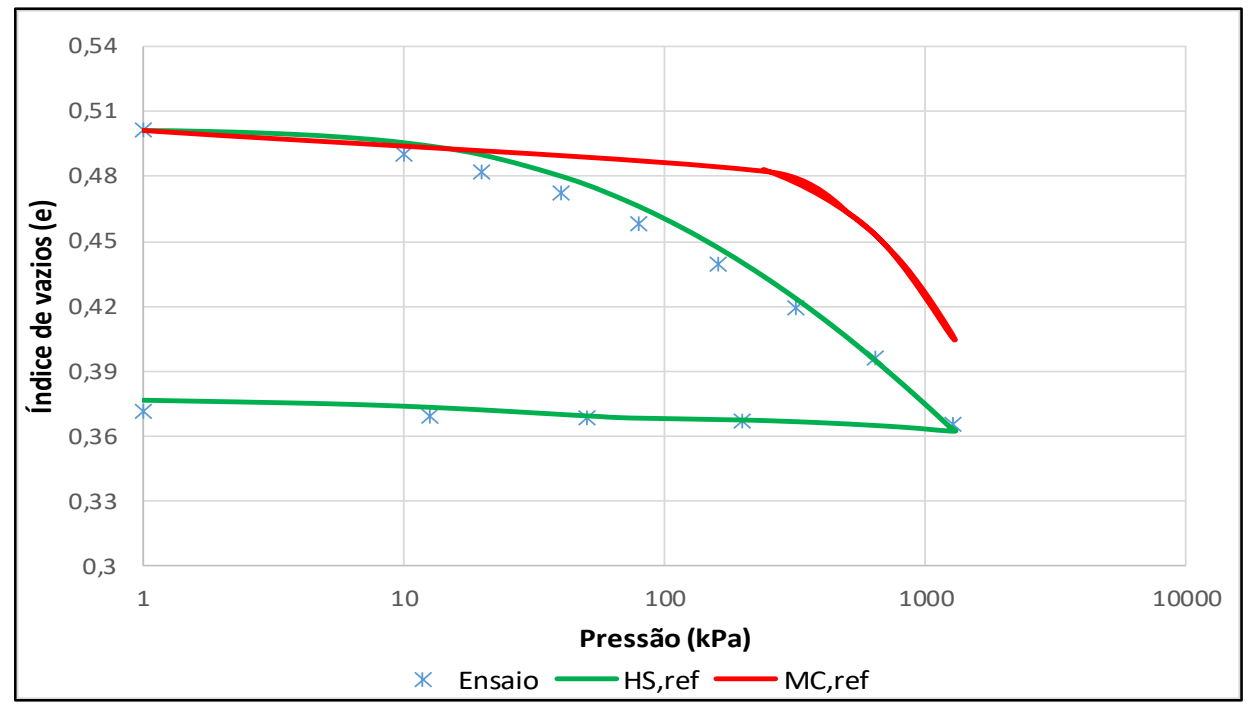




\subsection{ESTUDO DA REPRESENTAÇÃO DO COMPORTAMENTO DO SOLO PELOS MODELOS CONSTITUTIVOS}

Durante a escavação de um túnel, o solo ao redor da abertura é submetido a distintos carregamentos ao longo das etapas de construtivas. Para exemplificar este fato, Cecílio (2009) realizou um estudo com uma análise numérica tridimensional dividindo a região ao redor de uma escavação convencional em 6 partes distintas para avaliar as trajetórias de tensões que ocorrem em cada parte em diferentes etapas da escavação. Na Figura 5.16 é apresentada uma síntese de todas as trajetórias de tensões analisadas pelo autor.

Figura 5.16 - Síntese das trajetórias de tensão analisadas por Cecílio (2009).

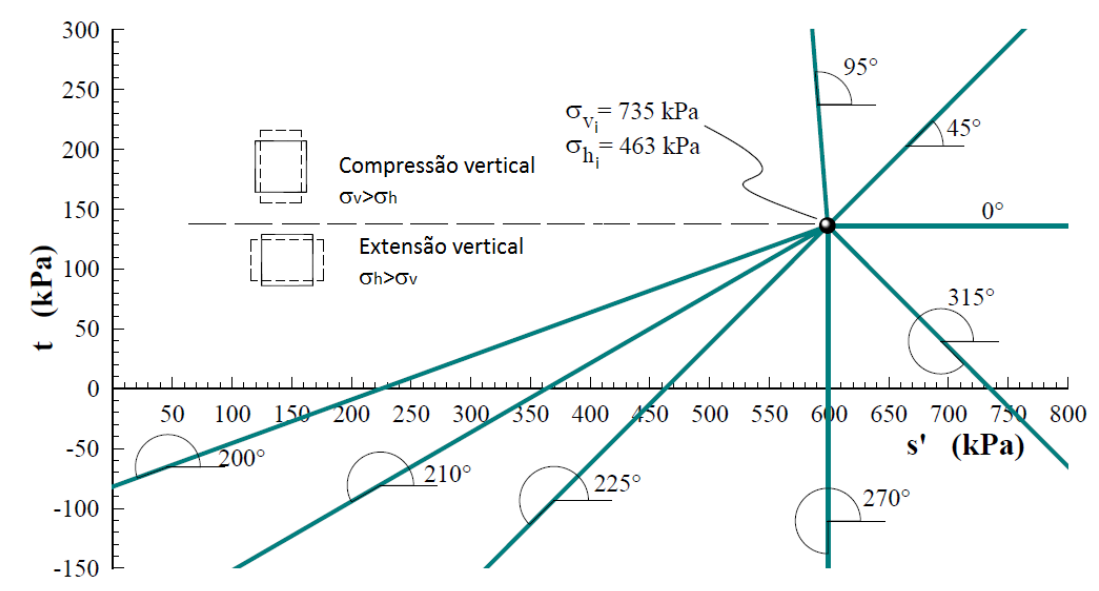

Fonte: Cecílio (2009).

Verifica-se, portanto, que é fundamental que o modelo constitutivo adotado consiga representar bem o comportamento do solo sob diferentes trajetórias de tensões. Por conta disso, foi realizado um estudo para verificar a capacidade dos dois modelos de representar o comportamento do solo sob diferentes trajetórias de tensões. Foram simulados quatro ensaios triaxiais com trajetórias de tensões distintas, representando quatro tipos de solicitação - compressão axial (CA), extensão axial $(E A)$, compressão lateral $(C L)$ e extensão lateral ( $E L)$. Foi simulado um adensamento representado uma situação de campo, considerando o ko adotado de 0,7, com tensão horizontal inicial de $100 \mathrm{kPa}$ e tensão vertical inicial de $143 \mathrm{kPa}$. Foram adotados os parâmetros de referência apresentados anteriormente. Cabe destacar que o ângulo de dilatância foi mantido nulo e adiante é feita uma análise específica sobre a influência deste parâmetro. Nos gráficos da Figura 5.24a são mostradas as trajetórias de tensões simuladas, a relação entre a tensão desviadora e a 
deformação axial e a relação entre as deformações volumétricas com as tensões axiais. Valores positivos de deformação volumétrica indicam aumento de volume e valores positivos de deformação axial indicam compressão do corpo de prova. Apesar de não se dispor de resultados de ensaio simulando estas trajetórias de tensão no solo em estudo, é possível comparar as curvas obtidas com dados da bibliografia e interpretá-las com base no conhecimento do comportamento esperado do solo.

Figura 5.17 - a) Estudo da representação do comportamento do solo sob diferentes trajetórias de tensões; b) Exemplo de ensaios reais.
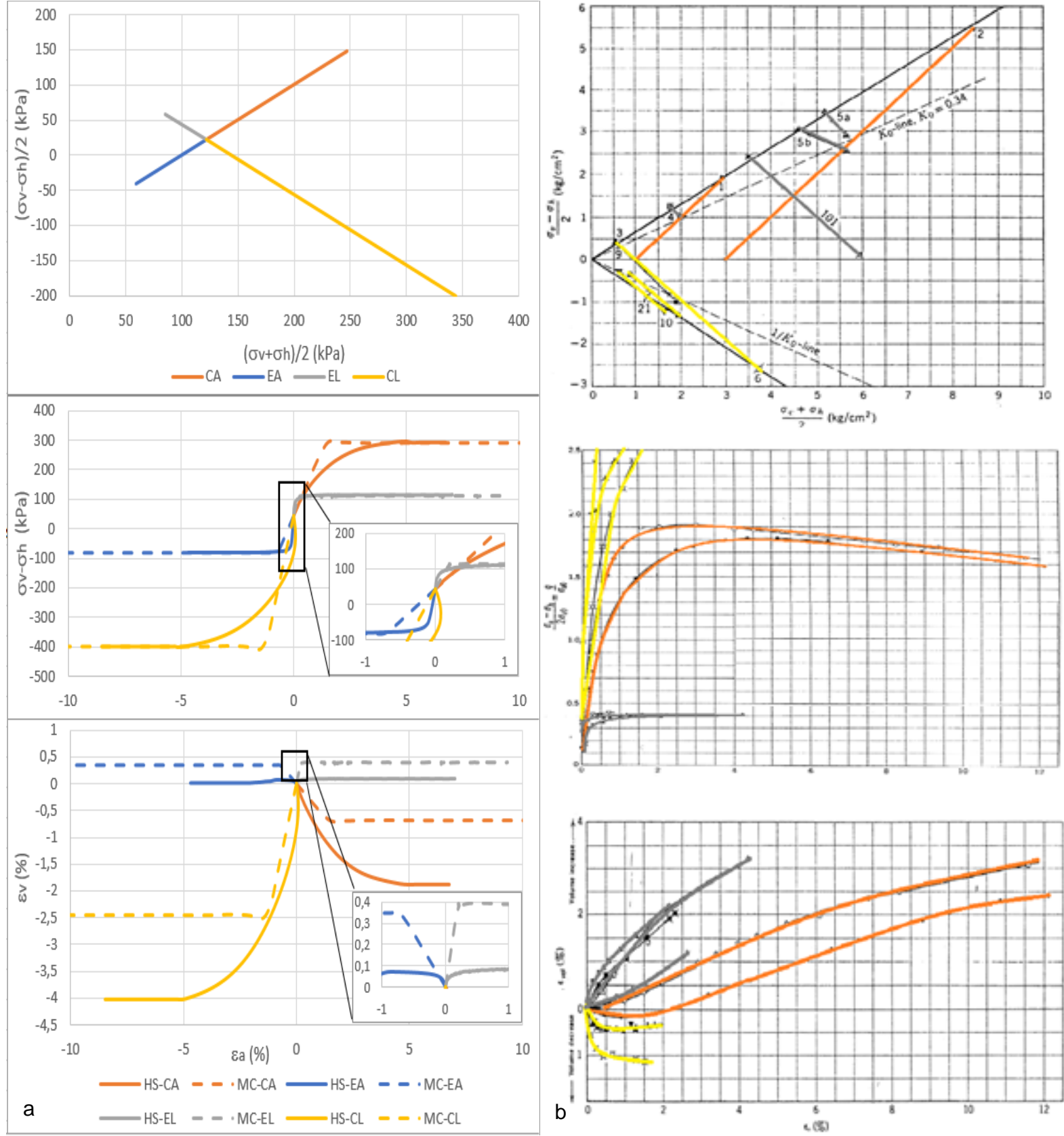

Fonte: adaptado de Lambe e Whitman (1969). 
Como exemplo da bibliografia disponível, a Figura 5.24b mostra gráficos disponíveis em Lambe e Whitman (1969), destacando com o mesmo padrão de cores as trajetórias de tensões simuladas neste estudo. Destaca-se que os exemplos de ensaios apresentados foram realizados em areias com comportamento dilatante, diferentemente da areia deste estudo.

Analisando os resultados obtidos, destaca-se:

- Gráfico tensão desviadora por deformação: conforme mencionado nas análises anteriores, a bilinearidade do modelo elastoplástico perfeito é uma limitação na representação do comportamento do solo. Em algumas faixas de deformação, a curva prevista pode se encontrar muito afastada do comportamento real do solo. A curva hiperbólica do modelo Hardening Soil representa o comportamento do solo com maior precisão nos ensaios de compressão. Nas duas simulações de extensão (EA e EL), o escoamento foi atingido sob baixas deformações e a principal diferença entre os modelos que se nota nestes ensaios é a rigidez sob baixas deformações nas duas curvas - enquanto o Hardening Soil permite considerar o comportamento mais rígido esperado do solo durante descarregamento e recarregamento, o modelo Mohr-Coulomb trabalha com o mesmo módulo de elasticidade da compressão sob estas solicitações. Comparando-se as curvas obtidas com os exemplos de curva de Lambe e Whitman (1969), observa-se boa concordância nos formatos das curvas previstas pelo modelo Hardening Soil.

- Gráfico deformação volumétrica por deformação axial: verifica-se mais uma vez que a bilinearidade do modelo Mohr-Coulomb é um grande limitante. Além disso, diferentemente das relações tensão-deformação, observa-se que a magnitude final da deformação volumétrica prevista é diferente nas curvas dos dois modelos. Nos ensaios de compressão (CA e CL), o modelo Mohr-Coulomb prevê incremento da contração do solo somente no regime elástico. Ao se atingir o escoamento (e se iniciar a plastificação), não há mais deformações volumétricas. Já no modelo Hardening Soil, por conta da possibilidade de expansão da superfície de plastificação, observa-se a continuidade da contração durante a plastificação, até que seja atingido o escoamento, resultando na previsão de contrações finais superiores. Já nos ensaios de extensão, o modelo Hardening Soil previu dilatação substancialmente inferior ao modelo Mohr-Coulomb. Este comportamento pode ser devido ao alto módulo de descarregamento utilizado no modelo Hardening Soil e 
está de acordo com o comportamento observado durante o descarregamento do ensaio edométrico. Comparando-se os resultados obtidos com as curvas disponíveis em Lambe e Whitman (1969), observa-se boa concordância no formato das curvas dos ensaios de compressão lateral. No entanto, nos demais ensaios observou-se um comportamento dilatante nas curvas de exemplo. Já que foi adotada como premissa dilatância nula nas simulações com os modelos, este comportamento não foi reproduzido.

Com base nestas avaliações, verificaram-se algumas deficiências importantes nos resultados fornecidos pelo modelo Mohr-Coulomb, que influenciam na previsão do comportamento do solo. O modelo Hardening Soil fornece previsões de comportamento mais realistas, utilizando parâmetros de fácil determinação a partir de ensaios de laboratório. Por isso, nas análises numéricas apresentadas a seguir foi utilizado somente o modelo Hardening Soil.

\subsection{MODELAGEM NUMÉRICA}

Para a realização de uma análise numérica de qualidade, é recomendável que se conheçam alguns conceitos envolvidos por trás de uma análise, tais como: a ferramenta numérica utilizada, o método de solução numérica adotado, a definição da malha de elementos e suas dimensões, além dos modelos constitutivos para o solo e para as estruturas a serem considerados.

O método dos elementos finitos (MEF) é a ferramenta numérica mais utilizada para análise de obras subterrâneas. Este método consiste na divisão de um meio contínuo em um número finito de elementos, os quais são conectados entre si por meio de pontos nodais, observando as condições de compatibilidade. A forma (quadriláteros, triângulos, etc.) e o tipo dos elementos dependem do tipo de problema envolvido e do programa utilizado. O conjunto de elementos constitui a malha. A definição da malha de elementos finitos influencia diretamente na precisão da solução alcançada e no tempo requerido para o processamento da análise. A discretização da malha resulta na redução do tamanho dos elementos finitos e é recomendável em zonas onde se esperam maiores alterações de tensões.

Outra definição importante é a posição das fronteiras do modelo. O tamanho da malha deve ser definido de maneira que as condições de contorno não influenciem 
nos resultados. Em geral, as fronteiras são definidas em distâncias de no mínimo 5 diâmetros do eixo do túnel, contudo é indicado que se façam estudos prévios para definição do tamanho da malha.

As análises numéricas a seguir foram realizadas utilizando-se o programa Plaxis 2D, desenvolvido pela Universidade de Delft, na Holanda. O programa utiliza o método dos elementos finitos para, por meio de cálculos evolutivos, realizar análises de deformação e estabilidade do maciço. O programa possibilita a utilização de diferentes modelos constitutivos para o solo, dentre os quais, o modelo Hardening Soil.

A geometria do modelo é composta por um túnel com diâmetro de 6,9 m e cobertura de 17,5 m. Após a realização de estudos prévios, foi adotada uma malha com a fronteira vertical localizada a 70,0 m (10D) do eixo do túnel e a fronteira horizontal inferior a 15,0 $\mathrm{m}(\sim 2 \mathrm{D})$ da base do túnel. A malha de elementos finitos foi refinada com maior proximidade entre os elementos em um contorno de $\sim 1 \mathrm{D}$ do perímetro da escavação, onde é esperada maior alteração das tensões. A malha utilizada é ilustrada na Figura 5.18.

Figura 5.18 - Malha utilizada nas análises.

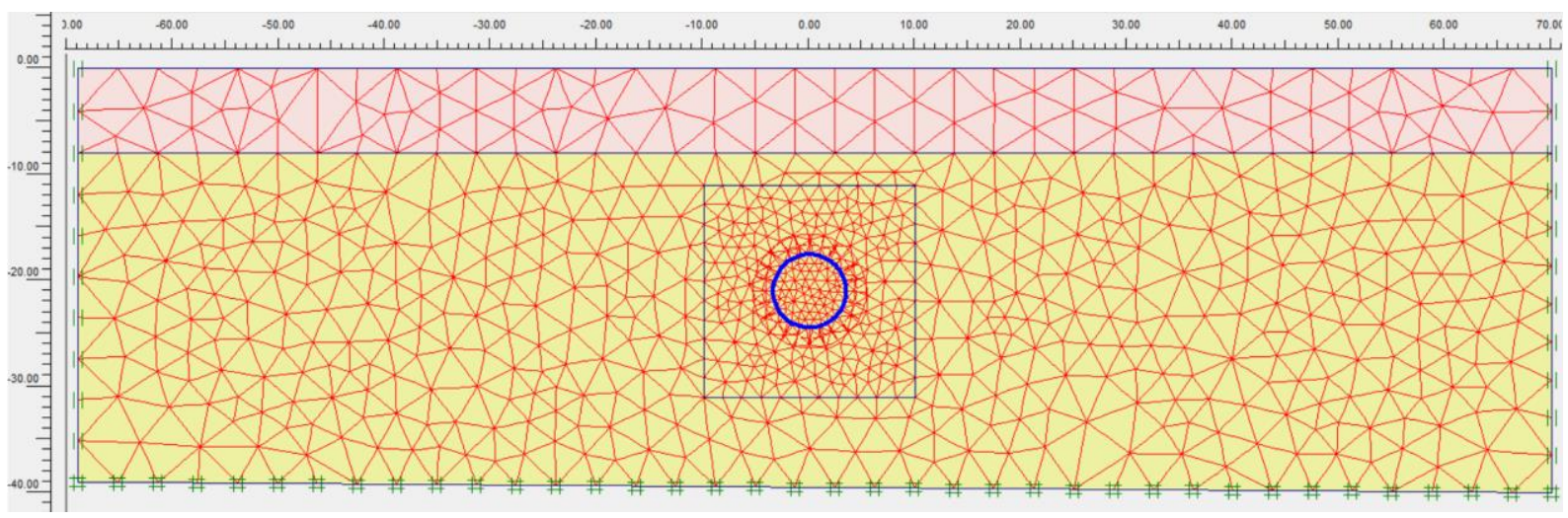

O revestimento do túnel foi modelado com comportamento elástico, com $30 \mathrm{~cm}$ de espessura, fck de $45 \mathrm{MPa}$ e módulo de elasticidade de 37,5 GPa. Foram realizadas análises com duas considerações distintas: revestimento contínuo e revestimento com 6 juntas, sendo estas posicionadas a cada $60^{\circ}$, com a primeira junta na coroa do túnel ( $0^{\circ}$ em relação ao eixo vertical). Para estimar a rigidez rotacional das juntas, seguiu-se a metodologia apresentada no item 4.4, conforme descrito por Thienert e Pulsfort (2011): 
1) Estimativa do esforço normal atuante no revestimento: valor obtido em função da cobertura, peso específico do solo e diâmetro da escavação. Para o caso em análise, estimou-se $700 \mathrm{kN}$;

2) Determinação do momento fletor limite $\left(M_{\min }\right)$, a partir do qual se inicia a rotação da junta, utilizando a Equação (4.6): $M_{\min }=N \cdot b / 6=700 \cdot 0,3 / 6=35 \mathrm{kNm}$;

3) Para simular a rigidez rotacional na junta, será utilizada como dado de entrada no Plaxis uma curva bilinear. O limite superior da curva é dado pelo momento máximo $\left(M_{\text {máx }}\right)$, definido como o momento para o qual o ângulo de rotação $\alpha$ atinge $1 \%$, valor assumido como máxima rotação possível. Tal relação é calculada utilizando a Equação (4.7), a partir da qual foi obtido $M_{m a ́ x}=97 \mathrm{kNm}$;

4) a rigidez rotacional da junta é dada pela relação $\Delta M / \Delta \alpha$. Para obtê-la, são calculados, utilizando-se a Equação (4.7), diversos pares de valores de momento atuante na rótula e ângulo de rotação, conforme apresentado na curva 1 do gráfico da Figura 5.19. A rigidez rotacional adotada é o coeficiente angular da reta 2, que corresponde à aproximação linear da curva 1 , sendo o ponto de intersecção das curvas adotado como 0,8 Mmáx. Neste caso, obteve-se uma rigidez rotacional de $70676 \mathrm{kNm} / \mathrm{rad}$.

Figura 5.19 - Relação entre momento fletor atuante e rotação na junta.

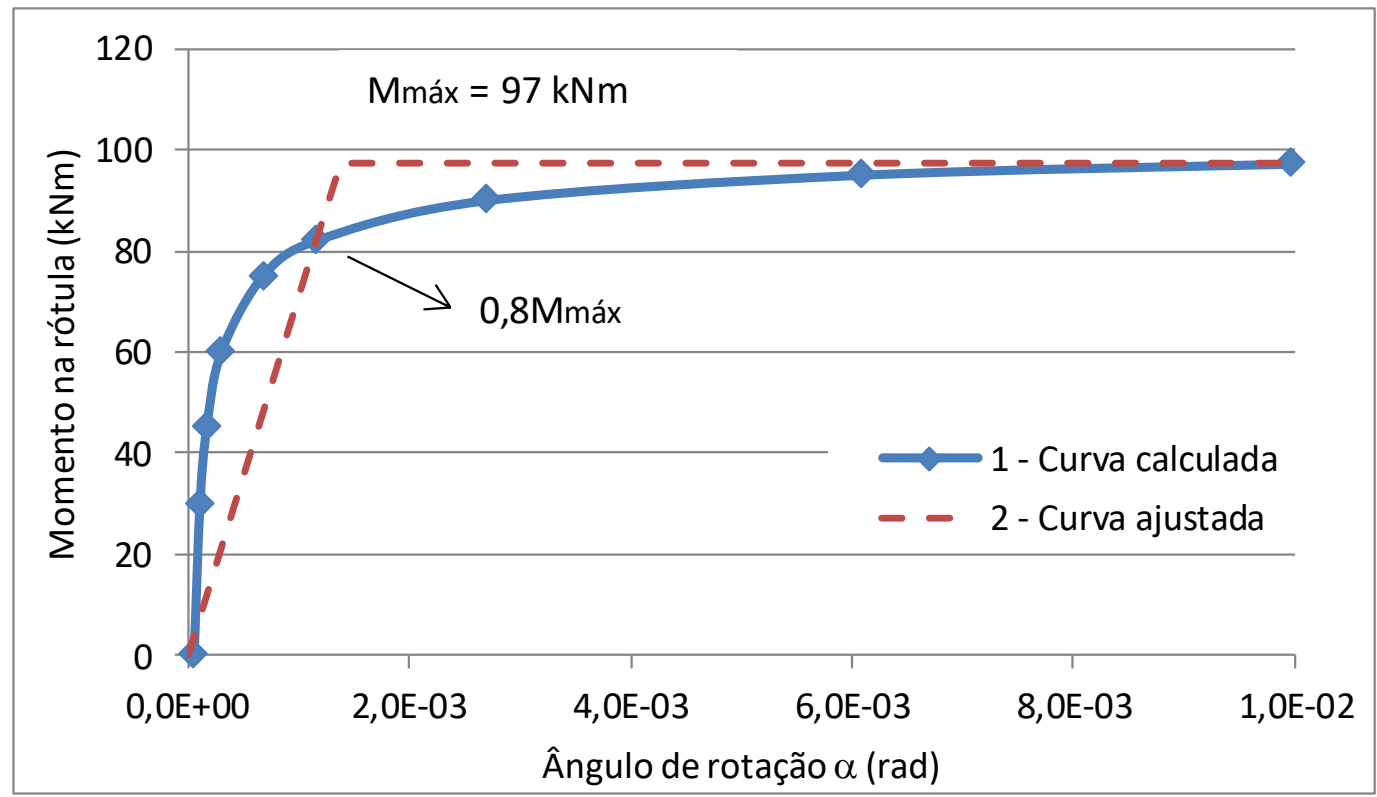

Foram realizadas 4 análises distintas e, para identificá-las, utilizou-se a seguinte designação: 
I - Método da contração, revestimento contínuo;

II - Método do alívio de tensões, revestimento contínuo;

III - Método da contração, revestimento com juntas;

IV - Método do alívio de tensões, revestimento com juntas.

Em todas as análises foram mantidos os parâmetros geotécnicos de referência apresentados anteriormente. O nível freático foi mantido na posição original e foi considerado estático, sem imposição de fluxo, já que a pressão de frente equilibra a pressão de água do terreno na frente da escavação e tanto o escudo da máquina quanto os anéis do revestimento são considerados impermeáveis. Foram realizadas análises drenadas considerando parâmetros geotécnicos efetivos.

As análises com os dois métodos distintos têm o objetivo de se obter os parâmetros de cálculo dos modelos (percentual de contração e fator de alívio) por meio de retroanálises que representem uma bacia aproximada dos recalques superficiais observados em campo. As variações dos modos de representar o revestimento visam avaliar a influência do tipo de representação do revestimento nos esforços solicitantes e nos recalques superficiais.

As etapas de cálculo são as seguintes:

1) Atribuição das condições de contorno de estado plano de deformação e a determinação do estado de tensão inicial sob efeito da gravidade. Após esta etapa, os deslocamentos ocorridos são zerados.

2) Desativação da camada referente ao solo escavado e aplicação de um dos métodos de cálculo:

a. no método da contração, ativa-se o revestimento do túnel;

b. no método do alívio das tensões, aplica-se um percentual das tensões in situ radialmente no perímetro da escavação, de acordo com o fator de alívio especificado.

3) Condição final da escavação:

a. no método da contração, redução da área do túnel até que o valor de contração especificado seja atingido;

b. no método do alívio, alívio total das tensões in situ no perímetro da escavação e instalação do revestimento do túnel. 


\subsubsection{Resultados obtidos e comentários}

A seguir são apresentadas análises comparativas entre os dois métodos de cálculo quanto aos pontos de plastificação calculados nos modelos, às diferenças entre previsões de recalques superficiais e aos esforços solicitantes estimados no revestimento. Nesta última comparação, são incluídas as análises realizadas considerando a junta entre os segmentos.

Nas Figuras 5.20 e 5.21 constam os elementos nos modelos onde ocorreram deformações plásticas na representação da situação final da escavação. O modelo Hardening Soil permite que estas ocorram antes do critério de ruptura MohrCoulomb ser atingido. Verifica-se que as deformações ocorridas não foram suficientes para se atingir o critério de ruptura em nenhum ponto - correspondente a legenda "pontos envoltória Mohr-Coulomb" nas figuras.

Observa-se também que nos dois modelos em diversos pontos houve plastificação ocasionada por compressão primária ("pontos endurecimento cap" nas figuras). Este comportamento ocorreu, pois, conforme mencionado anteriormente, no início da simulação os pontos já se encontravam na superfície de plastificação e com qualquer incremento de tensões média os pontos já entram em regime plástico.

Figura 5.20 - Pontos de plastificação calculados no modelo utilizando o método da contração.

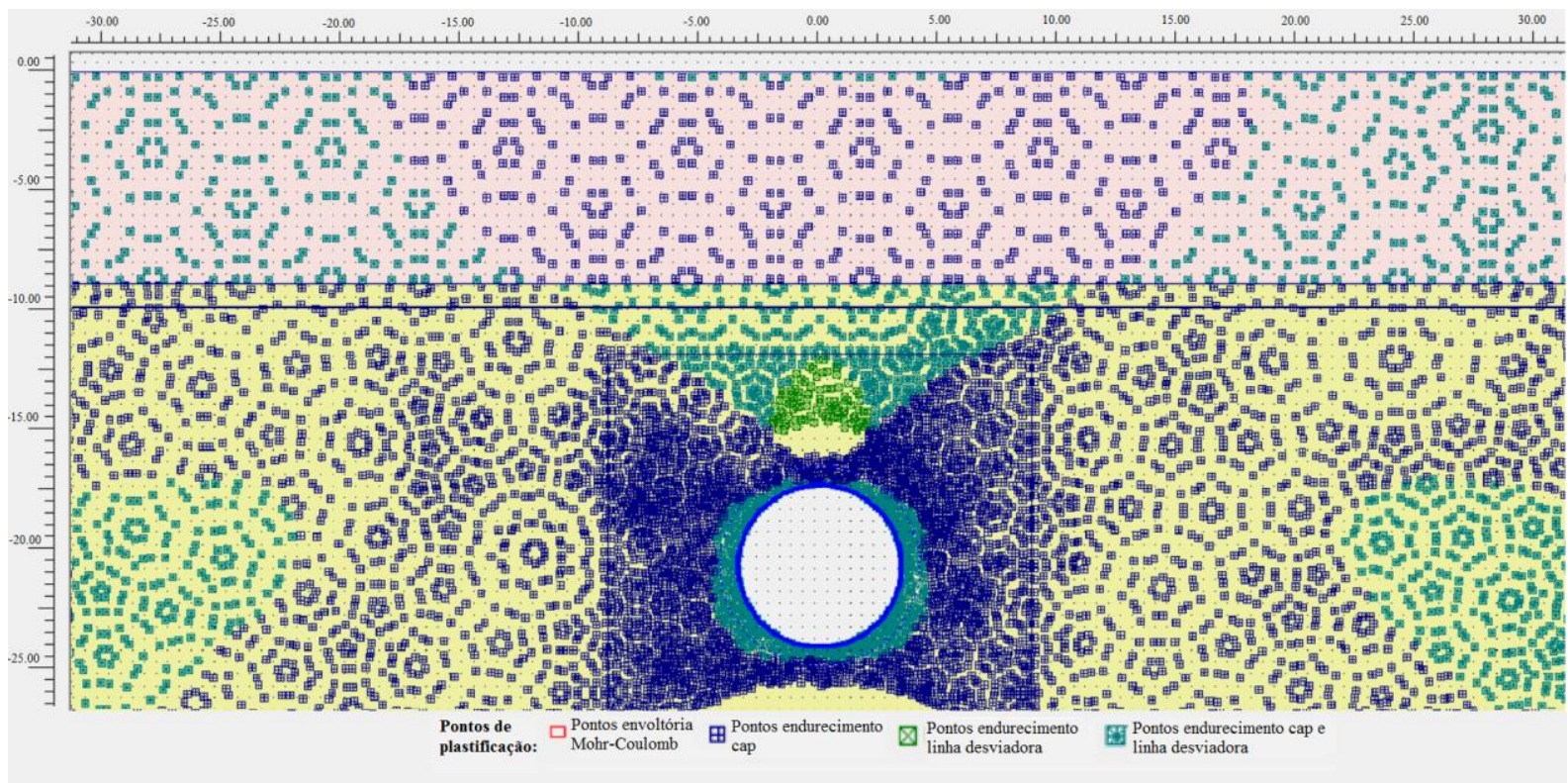


Figura 5.21 - Pontos de plastificação calculados no modelo utilizando o método do alívio de tensões.

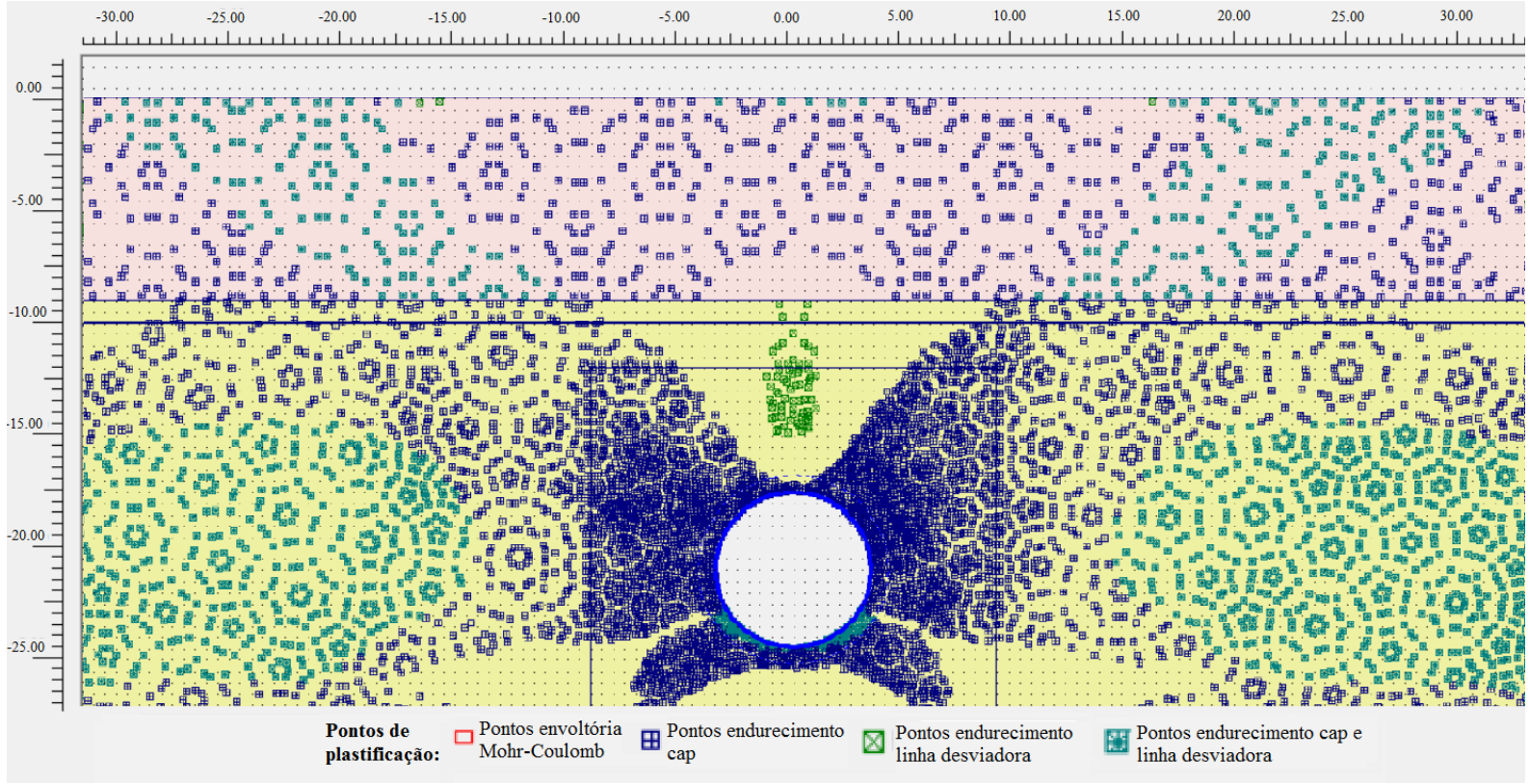

É interessante destacar as diferenças entre a distribuição dos pontos de plastificação calculados por cada método. No método da contração, verifica-se em todo o entorno da escavação a ocorrência de endurecimento por solicitação desviadora. Este comportamento é causado pela deformação imposta no maciço ao se realizar a contração da área da escavação. No caso de se seguir aumentando a contração aplicada, espera-se que alguns pontos no entorno atinjam a ruptura e passem a escoar.

Já na figura do método do alívio de tensões, pontos de endurecimento por carregamento desviador abaixo da base do túnel indicam plastificação provavelmente devido ao descarregamento provocado pela escavação do túnel. $\mathrm{Na}$ lateral do túnel, observam-se somente pontos de endurecimento isotrópico, sem plastificação por carregamento desviador. Na cobertura do túnel, a ocorrência de plastificação foi mais acentuada no modelo que utilizou o método da contração. Nas duas figuras é possível observar com nitidez o contorno da região onde ocorrem as maiores distorções no solo devido à escavação do túnel.

Os parâmetros de cálculo obtidos nas análises I e II para a simulação dos recalques superficiais medidos nas três etapas (passagem da frente e do escudo da máquina e o recalque final) são apresentados na Tabela 5-6 e as bacias de recalque obtidas na 
Figura 5.22. Lembrando que fator de alívio igual à unidade indica alívio completo das tensões in situ.

Tabela 5-6 - Parâmetros de cálculo obtidos para os dois métodos a partir das retroanálises.

\begin{tabular}{lccc}
\hline \multirow{2}{*}{ Método } & \multicolumn{3}{c}{ Recalque } \\
& Frente & Escudo & Final \\
\hline Contração & $0,18 \%$ & $0,28 \%$ & $0,38 \%$ \\
Fator de alívio & $18 \%$ & $23 \%$ & $28 \%$ \\
\hline
\end{tabular}

Figura 5.22 - Recalques superficiais obtidos pelas retroanálises utilizando os métodos da contração e do alívio.
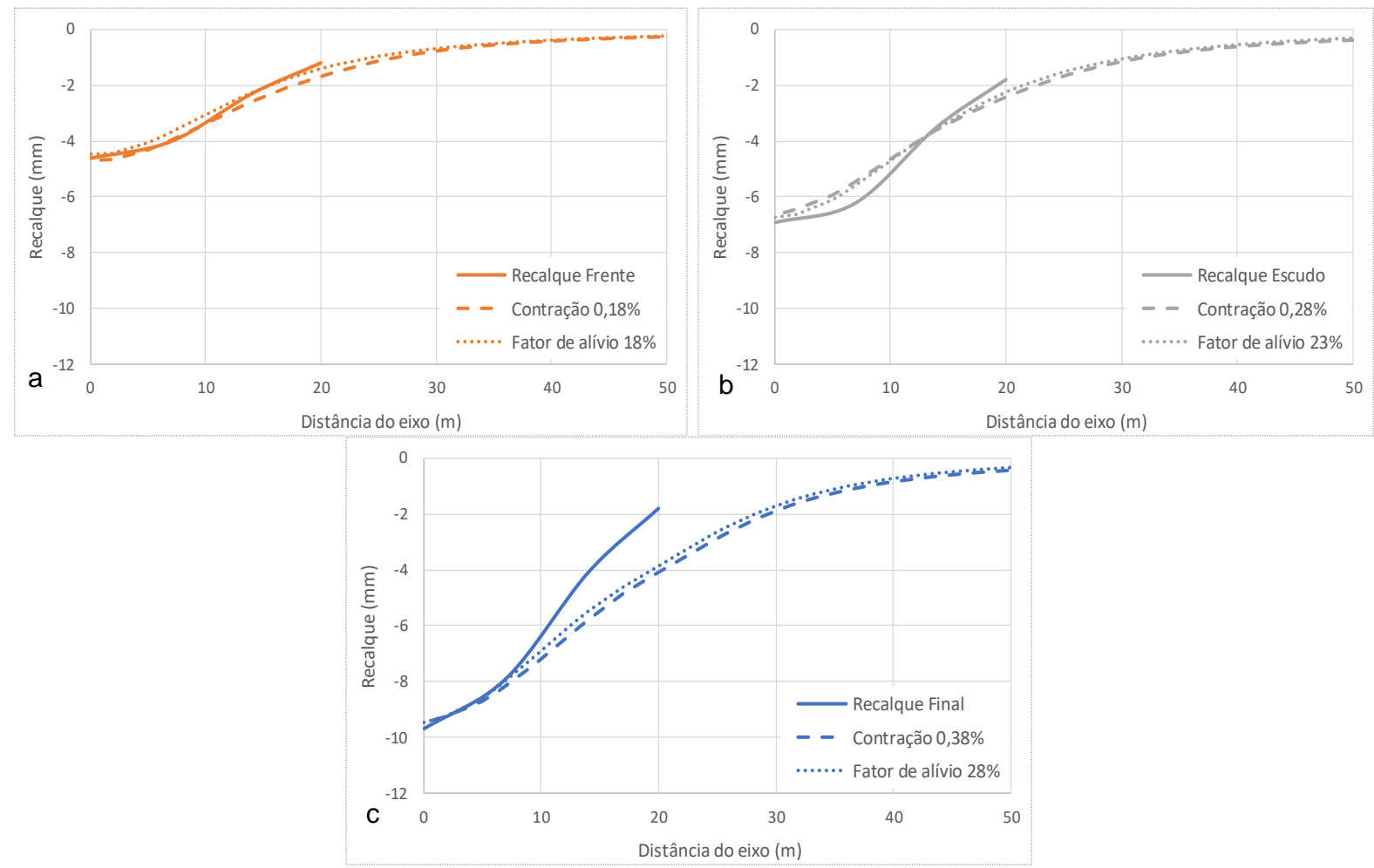

Primeiramente, verifica-se que a largura adotada para o modelo numérico foi adequada, pois não houve influência das bordas nos resultados obtidos. Observa-se também nos três gráficos que os dois métodos de cálculo produziram curvas de bacia de recalque com diferenças muito sutis, com o método do alívio de tensões prevendo bacias levemente mais estreitas. Hejazi, Dias e Kastner (2008), Möller e Vermeer (2008) e Do et al. (2014b) realizaram análises comparativas utilizando os dois métodos e também não verificaram diferenças relevantes no formato das bacias 
de recalques estimadas, sendo sempre a bacia estimada pelo método do alívio de tensões sutilmente mais estreita.

Nas retroanálises, optou-se por ajustar os parâmetros de cálculo de modo a se obter no modelo o recalque medido no eixo da escavação. O formato da bacia de recalques superficial da primeira curva (passagem da frente da máquina) foi bem representada pelos modelos. Já na terceira curva (recalque final), a bacia de recalques medida em campo teve largura inferior do que as previstas. Com isso, os percentuais de perda de solo estimados pelos modelos foram superiores aos ocorridos em campo (ocorrido - 0,7\%, estimado - 1,2\%). Nas retroanálises de Möller e Vermeer (2008), simulando uma escavação mecanizada de um túnel em solo arenoso na Holanda, os autores também obtiveram bacias mais largas no modelo do que a bacia medida em campo. Como são diversos fatores que influenciam na largura da bacia de recalques, como propriedades geotécnicas do solo e geometria da escavação, não é possível concluir se a falha na representação dos dados de campo é devido ao método de cálculo. Uma verificação mais aprofundada sobre este tema seria possível somente com a análise de mais dados de campo. Mesmo assim, destaca-se que é importante levar em consideração esta observação na elaboração de projetos.

A magnitude dos parâmetros de cálculo determinados é de difícil comparação, pois, como mencionado anteriormente, diversos fatores influenciam no comportamento do solo durante a escavação. Pode-se dizer que os resultados das simulações realizadas fornecem uma referência de valores de contração e fator de alívio a serem aplicados em simulações numéricas de uma escavação com máquina tuneladora em solo da Formação São Paulo.

Com relação aos modelos com juntas entre os segmentos (análises III e IV), a consideração das juntas não influenciou nos recalques superficiais estimados, conforme apresentado na Figura 5.23. Foi verificada uma diferença máxima da magnitude de recalque de somente $3 \%$ com relação às análises com o revestimento contínuo. Com isso, conclui-se que a maneira de representar o revestimento não tem influência nos recalques superficiais previstos. Em suas análises comparativas paramétricas, Do et al. (2014b) também chegaram nesta conclusão, inclusive na modelagem tridimensional. 
Figura 5.23 - Comparação da estimativa dos recalques superficiais nos modelos com e sem a consideração das juntas.

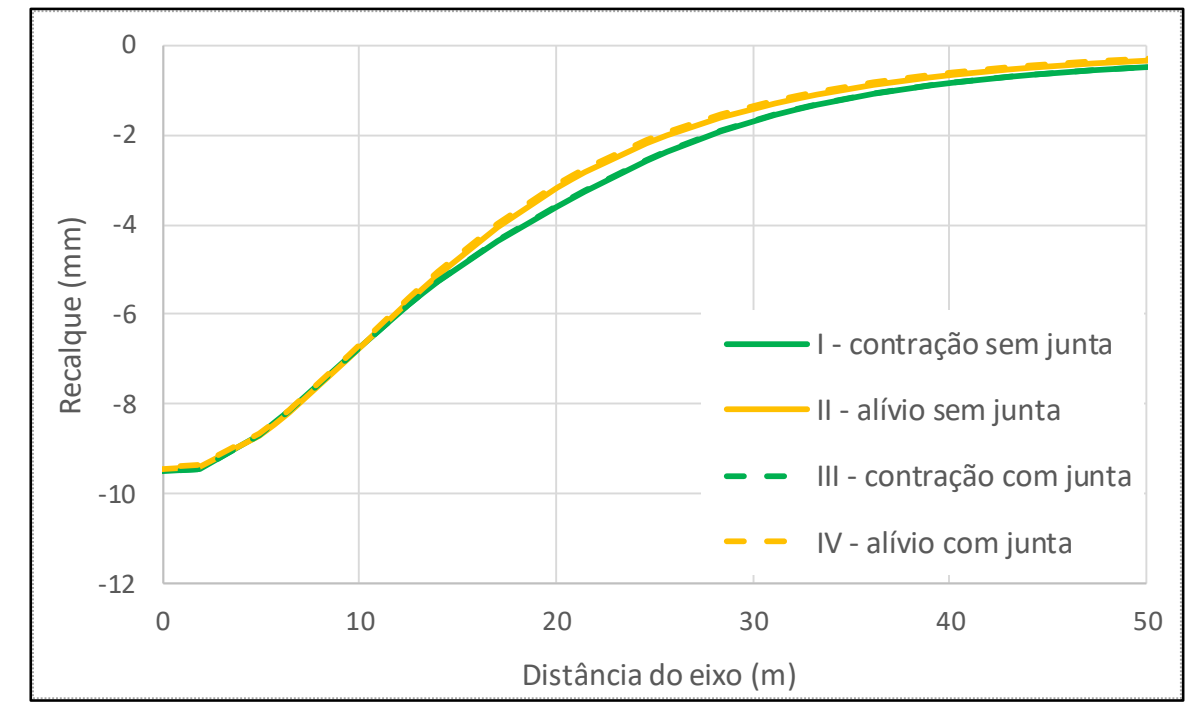

Já na comparação dos esforços solicitantes estimados no revestimento, verificou-se que a consideração das juntas afeta os resultados obtidos. Nas Figuras 5.24 e 5.25 apresentam-se, respectivamente, os esforços normais e momentos fletores obtidos ao longo do revestimento nas quatro análises e a Tabela 5-7 resume os máximos valores absolutos alcançados em cada análise. O esforço normal positivo indica compressão e o momento fletor positivo indica tração na face interna do revestimento. Como há simetria no modelo em relação ao eixo vertical, são apresentados os esforços somente na faixa entre $0^{\circ}$ e $180^{\circ}$ a partir do eixo vertical, no sentido horário, conforme indicado nas figuras.

Figura 5.24 - Estimativa dos esforços normais no revestimento nas quatro análises.

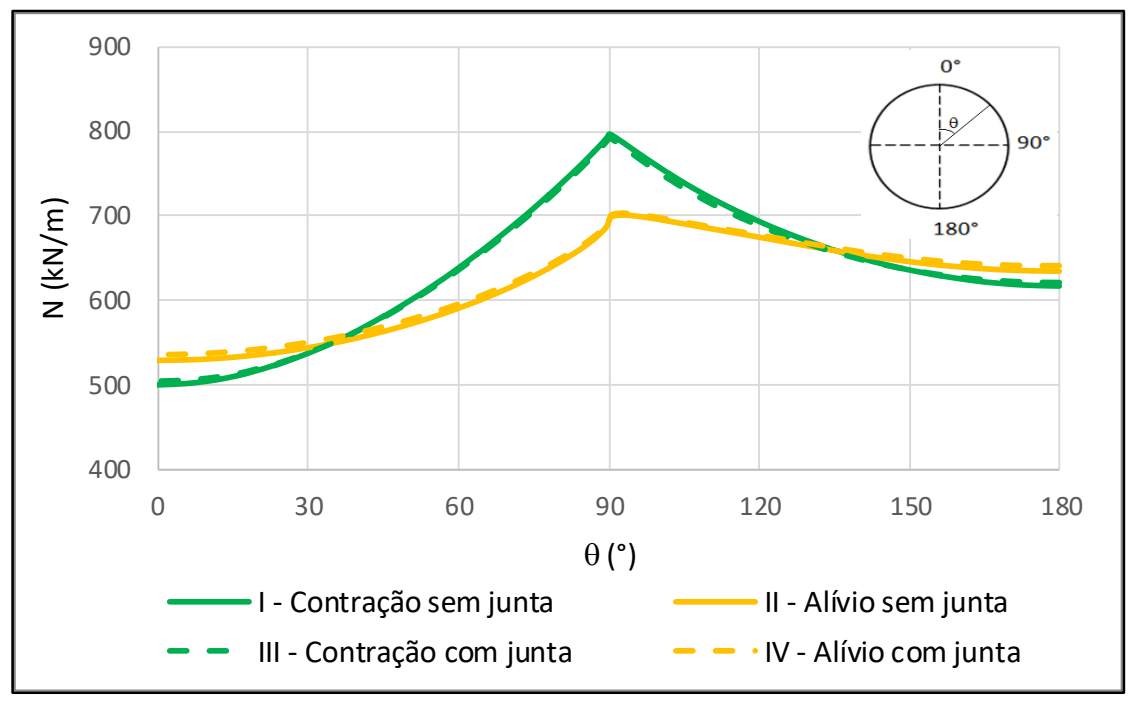


Figura 5.25 - Estimativa dos momentos fletores no revestimento nas quatro análises.

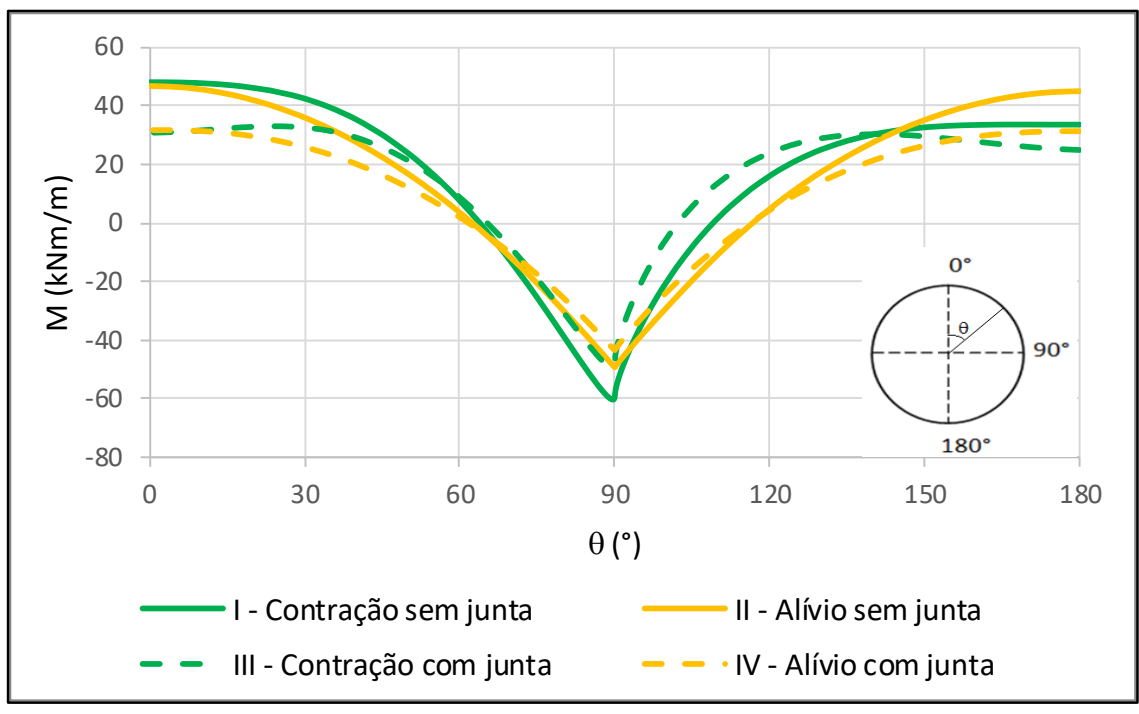

Tabela 5-7 - Esforços normais e momentos fletores absolutos máximos.

\begin{tabular}{lcccc}
\hline Análise & I & II & III & IV \\
\hline Nmáx $(k N / m)$ & 796 & 700 & 794 & 703 \\
Mmáx $(\mathrm{kNm} / \mathrm{m})$ & 60 & 49 & 53 & 43 \\
\hline
\end{tabular}

Comparando-se os esforços solicitantes determinados pelos dois métodos de cálculo considerando o revestimento contínuo (análises I e II), verifica-se que a simulação pelo método da contração forneceu esforços superiores aos calculados pelo método do alívio. As compressões obtidas foram até $13 \%$ superiores, enquanto que os momentos solicitantes foram de 12 a 31\% superiores. Möller e Vermeer (2008) e Do et al. (2014b) também observaram esta variação nas suas análises comparativas, contudo com diferenças percentuais ainda maiores - de 50 a $100 \%$ para os momentos fletores. Comparando os resultados obtidos pelos modelos com dados medidos em campo, Möller e Vermeer (2008) e Bilotta e Russo (2012) observaram que os esforços normais medidos pela instrumentação foram substancialmente superiores aos calculados em retroanálise nos modelos bidimensionais. Do et al. (2014b) destacam que resultados mais próximos dos dados de campo são obtidos a partir de análises tridimensionais, pois a simulação dos aspectos construtivos, como injeção do grout e apoio dos cilindros de empuxo nos segmentos, tem influência na magnitude final da compressão estimada numericamente. 
A diferença na estimativa dos esforços solicitantes entre os dois métodos pode ter origem nas diferenças entre as etapas de cálculo de cada um. O menor carregamento do revestimento no método do alívio das tensões pode ser devido ao suporte provisório proporcionado pela tensão interna aplicada no perímetro da escavação na simulação do alívio, antes da aplicação do revestimento no modelo. Isto proporciona um maior arqueamento das tensões e deformações ao redor da escavação, como observado nas análises dos pontos de plastificação obtidos por este método. Já no método da contração, há menos margem para redistribuição das tensões ao redor da escavação, pois o revestimento já é instalado na mesma etapa da escavação, ficando assim mais carregado. Após a aplicação da contração da área do túnel, há um alívio no carregamento do revestimento, contudo ainda assim menor do que no método do alívio das tensões.

$\mathrm{Na}$ comparação dos esforços solicitantes estimados entre os modelos com revestimento contínuo e com juntas (I e III, II e IV), verificou-se que praticamente não houve diferença nos esforços normais estimados. Este resultado era esperado, pois as rótulas que representam as juntas não afetam a transmissão da compressão entre os segmentos. Já os nos momentos fletores estimados, verificou-se relevante diferença: nos modelos com simulação das juntas, os momentos obtidos foram de 10 a $35 \%$ inferiores aos momentos estimados com o revestimento contínuo. Esta mesma ordem de grandeza foi obtida nas análises de Do et al. (2014b), sendo a diferença no método da contração maior do que no método do alívio de tensões. Cabe destacar que mesmo o momento limite calculado para a rótula de $97 \mathrm{kNm} / \mathrm{m}$ não sendo atingido, a rigidez rotacional imposta reduziu a magnitude dos momentos transferidos entre segmentos, validando a representação da junta entre os segmentos por uma rótula no programa. 


\section{CONCLUSÕES}




\section{CONCLUSÕES}

O uso de máquinas tuneladoras para a escavação de túneis em solo vem aumentando nos últimos anos no Brasil. Esta pesquisa tem o intuito de contribuir com o conhecimento nacional sobre este tema. $O$ foco desta pesquisa foram as máquinas tuneladoras do tipo de pressão de terra balanceada (EPB) e foram apresentados conceitos relevantes relacionados a este tipo de máquina, como princípios de funcionamento e operação, controles para estabilização da frente e mitigação das deformações induzidas, modos de operação, aspectos de condicionamento do maciço, entre outros. Destaca-se a importância de um correto cálculo e controle da pressão de frente aplicada pela máquina e também do preenchimento com volume e pressão adequado do espaço anelar para reduzir as perturbações no terreno e assim ocasionar menos recalques.

Em uma comparação entre a escavação convencional e a mecanizada, foram destacadas algumas diferenças importantes entre as metodologias, como segurança da escavação, velocidade de construção, ocorrência de recalques e danos a edificações, custos envolvidos, entre outras. Em geral, escavações mecanizadas tendem a ser mais seguras e tem o potencial de causar menos distúrbios no terreno do que a escavação convencional, por proporcionarem menor perturbação no maciço e eliminarem a necessidade de rebaixamento do lençol freático para escavação.

Aspectos importantes para a elaboração de um projeto de túnel com escavação mecanizada foram abordados. Diversos métodos analíticos para o cálculo da estabilidade da escavação, que fornece a base para a determinação da pressão de frente, foram descritos, destacando-se alguns métodos que foram desenvolvidos especificamente para escavação mecanizada. Avaliaram-se algumas causas de recalque associadas exclusivamente a escavações mecanizadas e apresentaram-se métodos empíricos de previsão de bacias de recalques, com algumas faixas de valores de perda de solo relatadas em casos de obras anteriores. Com relação ao dimensionamento do revestimento, foram enfatizadas algumas diferenças entre os anéis de revestimento de uma escavação mecanizada e o revestimento de uma escavação convencional. Um ponto fundamental que deve ser levado em conta é a presença da junta entre os segmentos. Diversos estudos citados mostram que a 
consideração da quantidade e disposição das juntas tem grande influência nos esforços solicitantes estimados.

Foram mencionados alguns trabalhos anteriores onde foram realizadas simulações numéricas de túneis, bi ou tridimensionais, aplicando diferentes modelos constitutivos para representar o solo. Destacou-se que todas as pesquisas nacionais realizadas até a elaboração desta dissertação contemplaram somente escavações convencionais e foram apresentadas algumas referências de trabalhos internacionais de modelos numéricos de escavações mecanizadas. A simulação da metodologia e das etapas construtivas é fundamental para se ter bons resultados em uma análise numérica. Foram mostrados exemplos de simulações tridimensionais que conseguem simular numericamente aspectos exclusivos de uma escavação mecanizada, como aplicação da pressão de frente, injeção do grout, representação do escudo e aplicação da força de propulsão.

Apesar das grandes vantagens proporcionadas por simulações tridimensionais, modelos bidimensionais em estado plano de deformações que permitem introduzir, mesmo que de forma aproximada, o efeito tridimensional da escavação, são de grande utilidade. Foram apresentados diversos métodos para converter um problema tridimensional em plano, destacando as premissas adotadas. Foram destacados dois métodos que são amplamente utilizados atualmente: o método do alívio de tensões e o método da contração, os quais foram aplicados nesta pesquisa. Com relação à modelagem do revestimento, maneiras de representação das juntas foram mostradas, com destaque à formulação que relaciona o momento fletor atuante com a rotação da junta.

O modelo constitutivo utilizado para representar o comportamento do solo é de extrema importância em análises numéricas. Foram descritos alguns conceitos básicos sobre modelos elastoplásticos, com uma breve apresentação sobre a formulação e parâmetros de entrada do modelo elastoplástico perfeito conhecido como Mohr-Coulomb e sobre o modelo elastoplástico com endurecimento Hardening Soil. A partir de ensaios de laboratório, foram determinados parâmetros geotécnicos de entrada dos dois modelos. Na sequência, os ensaios foram reproduzidos no programa de elementos finitos utilizando os dois modelos e os resultados obtidos foram comparados com os que foram medidos em laboratório. 
O modelo Mohr-Coulomb é amplamente utilizado, devido a sua simplicidade e à maior familiaridade que se tem com os parâmetros de entrada. Contudo, verificaramse algumas deficiências importantes neste modelo que influenciam na previsão do comportamento do solo, como a imposição de ocorrência de deformações plásticas somente ao se atingir o patamar de escoamento; a indistinção da representação da deformabilidade do maciço sob solicitações de carregamento e descarregamento (o que é muito importante em uma modelagem de um túnel); e, no gráfico de tensão desviadora por deformação, a curva bilinear fornecida pelo modelo se afasta consideravelmente da curva que representa o comportamento do solo em algumas faixas de deformação. O modelo Hardening Soil apresenta resultados bem melhores nestes pontos destacados, permitindo a ocorrência de plastificações antes de se atingir o escoamento, representando melhor a resposta do solo em situação de descarregamento e fornecendo durante a compressão uma curva com formato hiperbólico na relação entre tensão desviadora e deformação, que se aproxima bem do comportamento real do solo. Por conta destas diferenças, foi utilizado somente o modelo Hardening Soil nas análises numéricas realizadas. Encoraja-se que modelos mais elaborados do que o Mohr-Coulomb, que ainda assim utilizem parâmetros de fácil determinação a partir de ensaios de laboratório, sejam utilizados com mais frequência.

Modelagens numéricas foram realizadas para retroanalisar um caso real de escavação com máquina tuneladora. A seção em análise estava instrumentada com marcos superficiais e a escavação ocorreu em areia argilosa da Formação São Paulo, cujos parâmetros para o modelo Hardening Soil foram estimados a partir de ensaios de laboratório. Foi utilizado o programa Plaxis 2D e as análises visaram realizar uma comparação entre o método de alívio de tensões e o método da contração, além de simular o revestimento do túnel como contínuo e com consideração das juntas entre os segmentos. Para a representação das juntas, foram adotadas rótulas com rigidez à rotação e limitação de máximo momento fletor atuante. Parâmetros de cálculo (percentual de contração e fator de alívio) foram obtidos para o caso em análise e podem ser usados como referência em projetos futuros.

A comparação entre os dois métodos de cálculo mostrou pouca diferença no formato das curvas da bacia de recalques estimadas pelos modelos. Já os esforços 
solicitantes estimados foram maiores nas simulações utilizando o método da contração. A representação do revestimento com juntas teve relevância na estimativa dos momentos fletores, apresentando uma redução expressiva nos valores com relação às simulações com o revestimento contínuo. A representação das juntas como rótulas com rigidez à rotação mostrou-se adequada. Os resultados obtidos nas simulações estão de acordo com estudos semelhantes realizados anteriormente por outros autores. Pode-se concluir que ambos os métodos aplicados conseguiram representar a escavação mecanizada, sendo que os esforços solicitantes estimados no método da contração foram superiores. A maneira de simular as juntas se mostrou adequada. Recomenda-se em projetos futuros a instalação de instrumentação nos anéis para permitir uma comparação entre os esforços estimados nos modelos com os esforços reais.

\subsection{SUGESTÕES PARA TRABALHOS FUTUROS}

A seguir são apresentadas algumas sugestões para novos estudos relacionados a túneis escavados por máquinas tuneladoras. Com respeito aos aspectos relacionados à execução de uma escavação mecanizada, sugere-se:

- estudos sobre o condicionamento do maciço empregado durante a escavação para homogeneização do material escavado. Avaliar diferentes proporções de mistura de espuma com solo e verificar as propriedades obtidas, buscando determinar percentuais de misturas otimizados e também verificar a possibilidade de expandir a faixa de aplicabilidade de uma tuneladora do tipo EPB por meio do condicionamento;

- estudo da adesão das argilas na roda de corte e nas ferramentas de escavação (clogging). Conforme mencionado no texto, este é um dos grandes problemas enfrentados nas escavações. Uma possibilidade de pesquisa neste âmbito seria avaliar as propriedades físicas de argilas para buscar reduzir a ocorrência de clogging por meio de alternativas de condicionamento.

Sobre a relação dos parâmetros de operação da máquina com o comportamento do maciço:

- conforme citado, o cálculo da estabilidade fornece o valor mínimo de pressão de frente a ser aplicado. Contudo, para evitar deformações excessivas, pressões mais 
altas devem ser aplicadas. Sugere-se um estudo que relacione a magnitude da pressão de frente aplicada com a deformação do maciço.

Sobre a modelagem numérica de escavações mecanizadas:

- realização de análises paramétricas para verificar a influência da variação do percentual de contração e fator de alívio. Com isso será possível definir faixas de valores de trabalho típicas para representar a escavação mecanizada;

- comparação entre os dois métodos analisados com o método da pressão de grout citado neste trabalho;

- modelagem tridimensional simulando as etapas construtivas de uma escavação mecanizada;

- buscar uma relação entre a pressão de frente aplicada em um modelo tridimensional ou em campo com o percentual de contração e fator de alívio utilizados nos modelos. 


\section{REFERÊNCIAS BIBLIOGRÁFICAS}

ADDENBROOKE, T.I.; POTTS, D.M.; PUZRIN, A.M. The influence of pre-failure soil stiffness on the numerical analysis of tunnel construction. Geotechnique, v.47, n. 3 p.693-712, 1997.

AGUIAR, G.; SILVA, M.; KATAYAMA, L.; ROCHA, H. C. Acompanhamento técnico de tuneladora EPB: avaliação dos parâmetros operacionais da máquina. In: CONGRESSO BRASILEIRO DE TÚNEIS, 4, 2017, SÃO PAULO. Anais..., 2017.

ARNAU, O.; MOLINS, C. Experimental and analytical study of the structural response of segmental tunnel linings based on an in-situ loading test. Part 1: Test configuration and execution. Tunnelling and Underground Space Technology, v .26, p. 764-777, 2011a.

ARNAU, O.; MOLINS, C. Experimental and analytical study of the structural response of segmental tunnel linings based on an in-situ loading test. Part 2: Numerical simulation. Tunnelling and Underground Space Technology, v. 26, p. 778-788 2011b.

ANAGNOSTOU, G.; KOVÁRI, K. The Face Stability of Slurry-shield driven Tunnels. Tunnelling and Underground Space Technology, v.9, n. 2, p. 165-174, 1994.

ANAGNOSTOU, G.; KOVÁRI, K. Face Stability Conditions with Earth Pressure Balanced Shields. Tunnelling and Underground Space Technology, v.11, n. 2, 1996.

ATKINSON J. H.; POTTS D. M. Subsidence above shallow tunnels in soft ground. Journal of Geotechnical Engineering Division, ASCE, v. 103, p. 307-325, 1977.

BAKKER, K.J. Structural design of linings for bored tunnel in soft ground. Heron, v. 48, n. 1, p. 33-63, 2003.

BILFINGER, W.; SILVA, M. A.; ROCHA, H. C.; CELESTINO, T. B. Túneis em São Paulo. In: Negro et al. (Ed.). Twin Cities: solos das regiões metropolitanas de São Paulo e Curitiba. São Paulo: ABMS, 2013.

BILOTTA, E.; RUSSO, G. Back calculation of internal forces in the segmental lining of a tunnel: the experience of Line 1 in Naples. Geotechnical Aspects of Underground Construction in Soft Ground London: Taylor \& Francis Group, p. 213-221, 2012.

BROMS, B. B.; BENNERMARK, H. Stability of clay at vertical openings. Journal of Soil Mechanics and Foundation Division, ASCE, v. 93, n. 1, p. 71-94, 1967.

BUDACH, C.; THEWES, M. Application ranges of EPB shields in coarse ground based on laboratory research. Tunnelling and Underground Space Technology, v. 50, p. 296304, 2015.

CASTRO, A. O. Métodos para seleção de tuneladoras e análise numérica de diferentes alinhamentos de túneis sujeitos a altas pressões hidráulicas. 2013. 362 p. Dissertação (Mestrado) - Universidade de Brasília, Brasília, 2013.

CECÍLIO, M. O. (2009). Estudo do comportamento de um túnel em solo residual de gnaisse por meio de ensaios triaxiais com controle de trajetórias de tensões. 
2009. 204p. Dissertação (Mestrado) - Escola Politécnica da Universidade de São Paulo, São Paulo, 2009.

CELESTINO, T. B.; FERREIRA, A. A. Building damage associated to recent tunnels excavated for the São Paulo Subway. In: NORTH AMERICAN TUNNELING'96, 1996, Washington. Proceedings..., v. 1, p. 81-88, 1996.

CELESTINO, T. B.; RUIZ, A. P. T. Shape of settlement troughs due to tunnelling through different types of soft ground. Felsbau, v. 16, p.118-121, 1988.

CHAKERI, H.; OZCELIK, Y.; UNVER, B. Effects of important factors on surface settlement prediction for metro tunnel excavated by EPB. Tunnelling and Underground Space Technology, v. 36, p. 14-23, 2013.

CHANQUINI, C. V. Contribuição para Análise da Interação dos Revestimentos Primário e Secundário de Túneis em Solo Executados com Concreto Projetado. 2003. Dissertação (Mestrado) - Escola Politécnica da Universidade de São Paulo, São Paulo, 2003.

DAUB - Deutscher Ausschuss für unterirdisches Bauen. Recommendations for Face Support Pressure Calculations for Shield Tunnelling in Soft Ground. 2016. Disponível em: <http://www.daub-ita.de/fileadmin/documents/daub/gtcrec1/gtcrec10>. Acesso em: 06 Dez. 2016.

DAVIS, E. H.; GUNN, M. J.; MAIR, R. J.; SENEVIRATE, H. N. The stability of shallow tunnels and underground openings in cohesive material. Geotechnique, v. 30 n. 4, p. 397-416, 1980.

DIAS, D.; KASTNER, R. Movements caused by the excavation of tunnels using face pressurized shields - Analysis of monitoring and numerical modelling results.

Engineering Geology, v. 152, n. 1, p. 17-25, 2013.

DIMMOCK, P. S.; MAIR, R. J. Volume loss experienced on open-face London Clay tunnels. Proc. ICE Geot. Engrg v. 160, n. GE1, p. 3-11, 2007.

DO, N. A. Numerical analyses of segmental tunnel lining under static and dynamic loads. 2014. Tese (Doutorado) - INSA, Lyon, 2014.

DO, N. A.; DIAS, D.; ORESTE, P. P.; DJERAN-MAIGRE, I. 2D numerical investigation of segmental tunnel lining behavior. Tunneling and Underground Space Technology, v. 37, p. 115-127, 2013.

DO, N. A.; DIAS, D.; ORESTE, P. P.; ANTONELLO, C., DJERAN-MAIGRE, I, LIVIO, L. Stress and strain state in the segmental linings during mechanized tunnelling. Geomechanics and Engineering, v. 10, p. 75-85, 2014a.

DO, N. A.; DIAS, D.; ORESTE, P. P.; DJERAN-MAIGRE, I. 2D tunnel numerical investigation - the influence of the simplified excavation method on tunnel behaviour. Geotechnical and Geological Engineering, v. 32, n. 1, p. 43-58, 2014b.

DUDDECK, H.; ERDMAN, J. On structural design models for tunnels in soft soil. Underground Space, v. 9, n. 5-6, p. 246-253, 1985. 
DUNCAN, J. M.; CHANG, C. Y. Nonlinear analysis of stress and strain in soils. Journal of Soil Mechanics and Foundation Division, ASCE, v. 96, p. 1629-1653, 1970.

EINSTEIN, H. H.; SCHWARTZ, C. W. Simplified analysis for tunnel supports. Journal of Geotechnical Engineering, v. 105, n. GT4, p. 499-517, 1979.

FRANÇA, P. T. Estudo do comportamento de túneis: análise numérica tridimensional com modelos elastoplásticos. 2006. 185p. Dissertação (Mestrado) - Escola Politécnica da Universidade de São Paulo, São Paulo, 2006.

GUGLIELMETTI, V.; GRASSO P.; MAHTAB A.; and XU, S. Mechanized Tunneling in Urban Areas. London: Taylor \& Francis Group, 2008.

HEFNY, A.; CHUA, H. An investigation into the behavior of jointed tunnel lining. Tunnelling and Underground Space Technology, v. 21, p. 428, 2006.

HEINZ Jr., H. H. Large cross section tunnels in soft ground. 1988. 348p. Tese (Doutorado) - Universidade de Alberta, Edmonton. 1988.

HEJAZI, Y.; DIAS, D.; KASTNER, R. Impact of constitutive models on the numerical analysis of underground constructions. Acta Geotechnica, v. 3, p. 251-258, 2008.

HOLLMANN, F.S.; THEWES, M. Assessment method for clay clogging and disintegration of fines in mechanized tunneling. Tunnelling and Underground Space Technology, v. 37, p. 96-106, 2013.

ITA - International Tunnelling and Underground Space Association. Recommendations and Guidelines for Tunnel Boring Machines (TBMs). ITA-AITES, 118p., 2000.

ITA - International Tunnelling and Underground Space Association, Working Group No. 2. Guidelines for the design of shield tunnel lining. Tunnelling and Underground Space Technology, v. 15 n. 3, p.303-331, 2000.

ITA - International Tunnelling and Underground Space Association, Working Group Research. Settlements induced by tunneling in Soft Ground. Tunnelling and Underground Space Technology, v. 22, p. 119-149, 2007.

KARAKUS, M. Appraising the methods accounting for 3D tunnelling effects in 2D plane strain FE analysis. Tunnelling and Underground Space Technology, v. 22, p. 47-56, 2007.

KARAKUS, M.; FOWELL, R.J. Effects of different tunnel face advance excavation on the settlement by FEM. Tunnelling and Underground Space Technology, v. 18, n. 5, p. 513-523, 2003.

KASPER, T.; MESCHKE, G. A 3D finite element simulation model for TBM tunneling in soft ground. International Journal for Numerical and Analytical Methods in Geomechanics, v. 28, p. 1441-1460, 2004.

KLAPPERS, C.; GRÜBL, F.; OSTERMEIER, B. Structural analyses of segmental lining coupled beam and spring analyses versus 3D-FEM calculations with shell elements. Tunnelling and Underground Space Technology, v. 21, p. 254-255, 2006.

KOLYMBAS, D. Tunnelling and tunnel mechanics. Berlin: Springer. 2005. 
LAMBE, T. W.; WHITMAN, R. V. Soil Mechanics. New York: John Wiley \& Sons. 553p. 1969.

LECA, E.; DORMIEUX, L. Upper and lower bound solutions for the face stability of shallow circular tunnels in frictional material. Geotechnique, v. 40, n. 4, p. 581-606, 1990.

LEE, K. M.; HOU, X. Y.; GE, X. W.; TANG, Y. An analytical solution for a jointed shield driven tunnel lining. International Journal of Analytical and Numerical Methods in Geomechanics, v. 25, p. 365-390, 2001.

MÄHR, M.; HERLE, I. Volume loss and soil dilatancy. Rivista Italiana di Geotecnica, v. 38, n. 4, p. 32-41, 2004.

MAIDL, B.; HERRENKNECHT, M.; MAIDL, U.; WEHRMEYER, G. Mechanized shield tunnelling. Berlin: Ernst W. \& Sohn Verlag. 2012.

MAIDL, U.; COMULADA, M.; MONTEIRO, A. M.; MAIA, C. H. T.; PIERRI, J. C. D. Shield Tunnelling in Pure Sands - Merging the Application Fields of EPB and Slurry Shield Technology. In: WORLD TUNNEL CONGRESS. 2016, San Francisco. Proceedings..., San Francisco, 2016.

MAIDL, U.; Pierri, J. Innovative hybrid EPB tunnelling in Rio de Janeiro. Geomechanics and Tunneling, v. 7, n. 1, p. 55-63, 2014.

MAIR, R. J.; GUNN M. J.; O'REILLY, M. P. Ground movements around shallow tunnels in soft clay. In: INTERNATIONAL CONFERENCE ON SOIL MECHANICS AND FOUNDATION ENGINEERING, 10, Stockholm. Proceedings..., v. 1, p. 323-328, 1981.

MAIR, R. J.; TAYLOR, R. N. Bored tunneling in the urban environment. In: INTERNATIONAL CONFERENCE ON SOIL MECHANICS AND FOUNDATION ENGINEERING, 14, Hamburg. Proceedings..., v. 1, p. 2353-2385, 1997.

MARQUES, F. E. R. Comportamento de túneis superficiais escavados em solos porosos: o caso do Metrô de Brasília/DF. 2006. 462p.Tese (Doutorado) - Faculdade de Ciências e Tecnologia da Universidade de Coimbra, Coimbra. 2006.

MARSHALL, A. M. et al. Tunnels in sands: the effect of size, depth and volume loss on greenfield displacements. Geotechnique, v. 62, n. 5, p. 385, 2012.

MARTINS, P. A. Análise Numérica de Escavações Subterrâneas com Ênfase na Interação entre o Maciço e o Suporte em Concreto Projetado a Baixas Idades. 2008. 194p. Tese (Doutorado) - Universidade de Brasília, Brasília. 2008.

MASSAD, F. Resistência ao cisalhamento e deformabilidade de solos sedimentares da cidade de São Paulo. In: Negro et al. (Ed.). Twin Cities: solos das regiões metropolitanas de São Paulo e Curitiba. São Paulo: ABMS. 2013.

MÖLLER, S. C.; VERMEER, P. A. On numerical simulation of tunnel installation. Tunnelling and Underground Space Technology, v. 23, p. 461-475, 2008.

MOLLON, G.; DIAS, D.; SOUBRA, A. H. Probabilistic analysis and design of circular tunnels against face stability. International Journal of Geomechanics, ASCE, v. 9, n. 6, p. 237-249, 2009. 
MOLLON, G.; DIAS, D.; SOUBRA, A. H. Probabilistic analyses of tunnelling-induced ground movements. Acta Geotechnica, v. 8, p. 181-199, 2013.

MONTEIRO, M. D., GURGUEIRA, M. D., ROCHA, H. C. Geologia da Região Metropolitana de São Paulo. In: Negro et al. (Ed.). Twin Cities: solos das regiões metropolitanas de São Paulo e Curitiba. São Paulo: ABMS. p. 17-46. 2013.

MÜHLHAUS, H. B. Lower bound solutions for circular tunnels in two and three dimensions. Rock Mechanics and Rock Engineering, v.18, 37-52, 1985.

MUIR-WOOD, A. M. The circular tunnel in elastic ground. Geotechnique, v. 25, n. 1, p. 115$127,1975$.

NEGRO Jr., A.; SOZIO, L. E.; FERREIRA, A. A. Túneis. In: Solos da Cidade de São Paulo. São Paulo: ABMS. 1992.

NEGRO Jr., A. Soil tunnels and their supports. In: CONGRESSO BRASILIERO DE MECÂNICA DOS SOLOS, 10, Foz do Iguaçu. Anais..., p. 33-60, 1994.

NEGRO Jr., A.; QUEIROZ, P. I. Prediction and performance: a review of numerical analysis for tunnels. Geotechnical Aspects of Underground Construction in Soft Ground. Balkema, Tokyo, Japan, p. 409-418, 1999.

OHNISH, Y.; NISHIGAKI, Y.; KISHIMOTO, H.; TANAKA, Y. Analysis of advancing tunnel by 2-dimensional FEM. INTERNATIONAL CONFERENCE ON NUMERICAL METHODS IN GEOMECHANICS, 4, Edmonton. Proceedings..., p. 571-578, 1982.

ORESTE, P. Analysis of structural interaction in tunnels using the convergence confinement approach. Tunnelling and Underground Space Technology, v. 18, p. 347-363, 2003.

ORESTE, P. A numerical approach to the hyperstatic reaction method for the dimensioning of tunnel supports. Tunnelling and Underground Space Technology, v. 22, n. 2, p. 185-205, 2007.

ORESTE, P. The Convergence-Confinement Method: Roles and Limits in Modern Geomechanical Tunnel Design. American Journal of Applied Sciences, v. 6, p. 757$771,2009$.

O'REILLEY, M. P.; NEW, B.M. Settlements above tunnels in the United Kingdom - their magnitude and prediction. In: TUNNELLING'82, London. Proceedings..., p. 173-181, 1982.

PANET, M.; GUENOT, A. Analysis of convergence behind the face of a tunnel. In: TUNNELLING'82, London. Proceedings..., p. 197-204, 1982.

PARREIRA, A. B. Análise de túneis rasos em solo: o túnel mineiro Paraíso da linha paulista do metropolitano da cidade de São Paulo. 1991, 296p. Tese (Doutorado) Pontifícia Universidade Católica do Rio de Janeiro, Rio de Janeiro, 1991.

PECK, R. B Deep excavations and tunneling in soft ground. In: INTERNATIONAL CONFERENCE ON SOIL MECHANICS AND FOUNDATION ENGINEERING, 7 , Cidade do México. Proceedings..., p. 225-290, 1969. 
PLAXIS BV. Plaxis Material Models Manual. Rotterdam: A. A. Balkema, 226p. 2016.

POTTS, D.M. Numerical analysis: a virtual dream or practical reality? $42^{\text {nd }}$ Rankine Lecture, Geotechnique, v. 53, n. 6, p. 533-574, 2003.

POTTS, D.M.; ZDRAVKOVIC', L. Finite Element Analysis in Geotechnical Engineering: Application. London: Thomas Telford, 427p., 2001.

POTTS, D.M.; ZDRAVKOVIC', L. Finite Element Analysis in Geotechnical Engineering: Theory. London: Thomas Telford, 439p., 1999.

POWELL, D.B.; SIGL, O.; BEVERIDGE, J.P. Heathrow-Express design and performance of platform tunnels at Terminal 4. In: TUNNELLING'97, London. Proceedings..., p. 565593, 1997.

ROCHA, H. C.; COMULADA, M.; MAIDL, U.; MAIA, C. (2014) São Paulo Metro developments in Shield tunneling. Geomechanics and Tunneling, v. 7, n. 3, p. 237247, 2014.

ROWE, R.K., LO, K.Y., KACK, K.J. A method of estimating surface settlement above shallow tunnels constructed in soft ground. Canadian Geotechnical Journal, v. 20, p. 11-22, 1983.

RUIZ, A. P. T. Análise de Túneis Rasos em Solos Porosos - Mecanismos de Formação de Recalques. 1997. Dissertação (Mestrado) - Escola de Engenharia de São Carlos, Universidade de São Paulo. 1997.

SAUER, G. NATM and its toolbox. In: EARTH RETENTION SYSTEMS: A JOINT CONFERENCE, 2003, New York. Proceedings..., ASCE, 2003.

SILVA, M. A. A. P. Simulações Numéricas para Escavações Subterrâneas. 2008, 133p. Dissertação (Mestrado) - Instituto Tecnológico de Aeronáutica, São José dos Campos. 2008.

SILVA, M. A. A. P. et al. Construction Aspects for Lot 3 São Paulo Metro Line 5 Expansion. In: WORLD TUNNEL CONGRESS, Geneve, 2013. Proceedings..., 2013.

SILVA, M. A. A. P.; AGUIAR, G.; FERREIRA, A. A; ROCHA, H. C.; HARTWIG, M. E. Lições Aprendidas na Escavação de Túneis Paralelos da Linha 5 - Lilás do Metrô de São Paulo; In: CONGRESSO BRASILEIRO DE MECÂNICA DOS SOLOS E ENGENHARIA, 2016, Belo Horizonte. Anais..., 2016.

SILVA, M. A. A. P. S.; AGUIAR, G.; TEIXEIRA, I. J.; FERREIRA, A. A. Desafios e soluções construtivas aplicadas na escavação de um túnel em saprólito e solo residual de gnaisse da Linha 5 - Lilás do Metrô de São Paulo. In: CONGRESSO BRASILEIRO DE TÚNEIS, 4, 2017, SÃO PAULO. Anais..., 2017.

SWOBODA, G. Finite element analysis of the New Austrian Tunnelling Method (NATM). In: International Symposium on Numerical Models in Geomechanics, 3, Aachen, 1979.

Proceedings...., v. 2, p. 581, 1979.

THIENERT, C.; PULSFORT, M. Segment design under consideration of the material used to fill the annular gap. Geomechanics and Tunneling, v. 4, p. 665-679, 2011. 
TUNNEL FACE STABILITY SOFTWARE. Disponível em <http://guilhem.mollon.free.fr>. Acesso em 04 mai. 2016.

VERMEER, P. A.; BONNIER, P. G.; MÖLLER, S. C. On a smart use of 3D-FEM in tunnelling. In: International Symposium on Numerical Models in Geomechanics, 8, Rome, 2002. Proceedings..., Balkema, Roterdam, p. 361-366, 2002.

VERMEER, P. A.; de BORST, R. Non-Associated Plasticity for Soils, Concrete and Rock. Heron. v. 29, n. 3, p. 1-64, 1984.

VINAI, R.; OGGERI, C.; PEILA, D. Soil conditioning of sand for EPB applications: A laboratory research. Tunnelling and Underground Space Technology, v. 23, n. 3, p. 308-317, 2007. 